\title{
Editora Poisson
}

Semiárido Brasileiro

\section{Volume}


Editora Poisson

\section{Semiárido Brasileiro Volume 2}

1a Edição

Belo Horizonte

Poisson

2019 
Editor Chefe: Dr. Darly Fernando Andrade

\section{Conselho Editorial}

Dr. Antônio Artur de Souza - Universidade Federal de Minas Gerais Msc. Davilson Eduardo Andrade

Msc. Fabiane dos Santos Toledo

Dr. José Eduardo Ferreira Lopes - Universidade Federal de Uberlândia Dr. Otaviano Francisco Neves - Pontifícia Universidade Católica de Minas Gerais

Dr. Luiz Cláudio de Lima - Universidade FUMEC

Dr. Nelson Ferreira Filho - Faculdades Kennedy

Msc. Valdiney Alves de Oliveira - Universidade Federal de Uberlândia

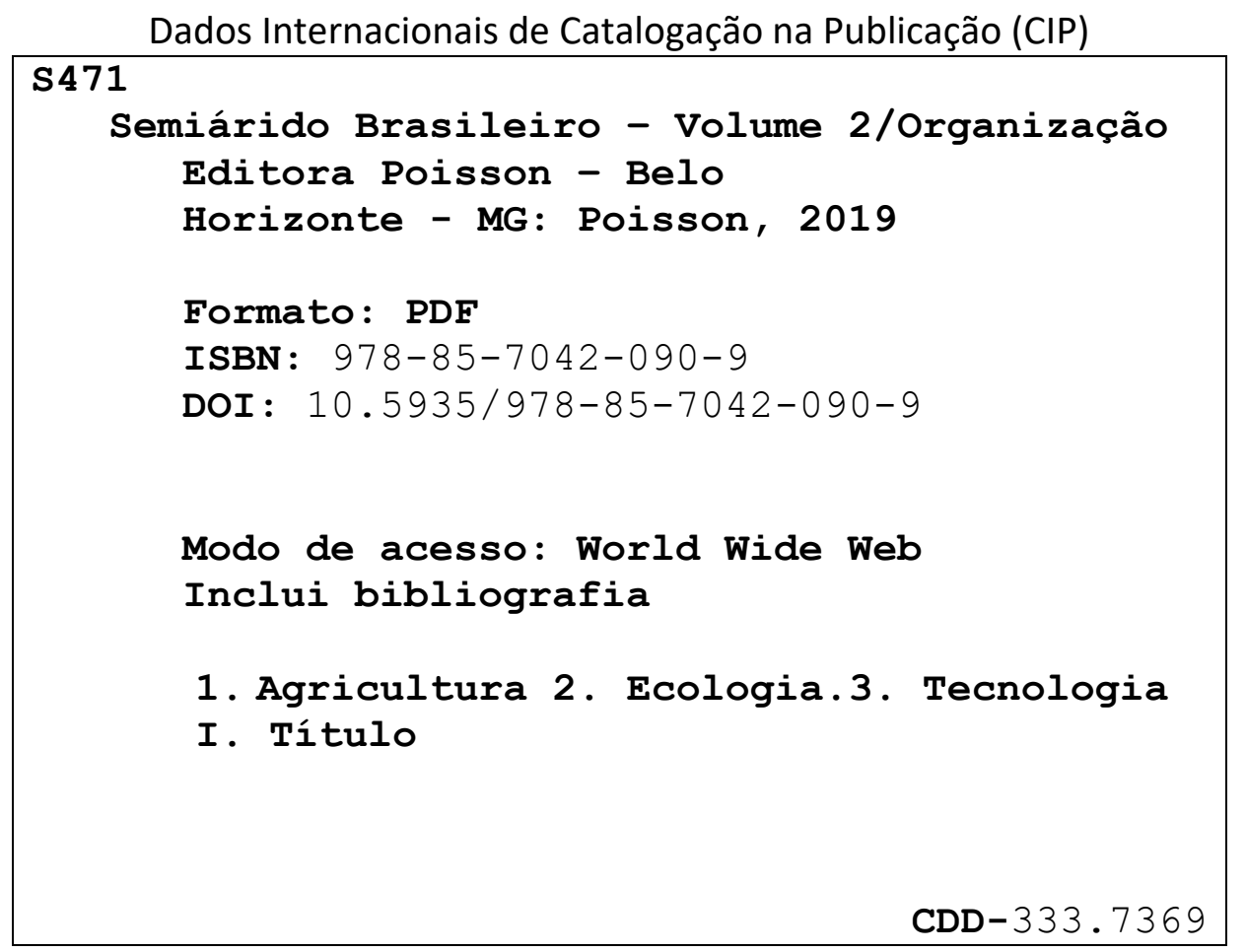

O conteúdo dos artigos e seus dados em sua forma, correção e confiabilidade são de responsabilidade exclusiva dos seus respectivos autores.

$\underline{\text { www.poisson.com.br }}$

contato@poisson.com.br 


\section{SUMÁRIO}

Capítulo 1: Estratégias para a inserção de armazenamento energético em regiões semiáridas: Variabilidade e aplicabilidade de tecnologias.

Caio Tácito Miranda Castro Bezerra de Melo, Daniel de Paula Diniz, Ana Katarina Pessoa de Oliveira, Monica Carvalho

Capítulo 2: Avaliação dos impactos ambientais gerados pela pequena mineração no município de Picuí:PB

Ailma Roberia Souto de Medeiros, Jaqueline de Souza Dantas, Paulo Sales da Costa Barros, Ligia Mara Gonzaga

Capítulo 3: Cultivo e extrativismo da mangaba no Vale do Sambito: Uma estratégia economica para o municipio de Inhuma-Pi...

Francisco José dos Santos, Neydiane Pereira Lopes, Olímpio José dos Santos, Claudimeire Lima de Sousa

Capítulo 4: Veredas do semiárido cearense: 0 fomento ao geoturismo no parque estadual das Carnaúbas.

Hermógenes Henrique Oliveira Nascimento

Capítulo 5: Migração sazonal de trabalhadores do semiárido com destino aos canaviais 44

Wallysson Klebson de Medeiros Silva, Daisy Caroline Nascimento Pereira, Jean Carlos dos Santos, Susane Eterna Leite Medeiros, Raniela Alves Targino, Emanuel Jhonata Gomes da Silveira

Capítulo 6: Perspectiva de familiares na convivência com os portadores de transtornos mentais

Nívea Mabel Medeiros, Rita Duarte Brito Dantas, Aissa Romina Silva do Nascimento, Rogênia Araújo Campos, Genicléia Lisboa Rolim

Capítulo 7: As TIC's como proposta de inovação do conhecimento na agricultura familiar do Semiárido Potiguar Brasileiro..

Zildenice Matias Guedes Maia, Christiane Fernandes dos Santos, Danielle Simone da Silva Casillo, Leonardo Augusto Casillo

Capítulo 8: A cantoria de viola no universo do semiárido brasileiro: Um ciclo de memórias que se ressignificam em espaços moventes.

Marcelo Vieira da Nóbrega, Edmilson Ferreira dos Santos, Maria Ignez Novais Ayala 


\section{SUMÁRIO}

Capítulo 9: Saberes tradicionais do semiárido piauiense: Proposta de inclusão curricular 73

Maria Alveni Barros Vieira, Adauto Neto Fonseca Duque, Maria das Dores de Sousa, Thatianny Jasmine Castro Martins de Carvalho, Luiza Xavier de Oliveira

Capítulo 10: Experiência da educação contextualizada para a convivência com o semiárido em uma escola do campo do município de Ipiranga do Piaui, Piauí, 80

Bruna Lara Borges da Silva, Suzana Gomes Lopes, Gardner de Andrade Arrais, Tamaris Gimenez Pinheiro

Capítulo 11: Projeto Prospera Caatinga: Cartilha ambiental e o recaatingamento..... 89 Ithany Felipe Alcântara da Silva, Cláudio Roberto Meira de Oliveira

Capítulo 12: Olimpíadas científicas: A informática como instrumento de melhoria de qualidade de vida e de aprendizagem. 93

Williams Alves Xavier, Izaias Romario Soares do Nascimento, Márcia Verônica Costa Miranda

Capítulo 13: 0 curso de bacharelado em direito da UESPI, campus de Picos (PI): 0 fortalecimanto da educação jurídica no Semiárido Piauiense .

Lauro Brandão Lima Neto, Evandro Alberto de Sousa, Luciano Silva Figueirêdo, Janaína Alvarenga Aragão, Lucelia de Moura Rocha Barbosa, Alekssandro Sousa Libério

Capítulo 14: Semente crioula e sua importância na agricultura familiar do Semiárido Brasileiro 105

Kilson Pinheiro Lopes, Marília Hortência Batista da Silva Rodrigues, Maria Verônica Lins, Hugo Vieira

Capítulo 15: Aspectos biométricos das sementes de Croton Heliotropiifolius kunth (Euphorbiaceae) em um gradiente topográfico no semiárido brasileiro..

Lúcia Virginia Castor do Rêgo, Gilbevan Ramos de Almeida, D`Ávilla Ruama Fernandes Lopes Gomes, Maiara Bezerra Ramos, Humberto Araújo Almeida, Fabrício Correia Diniz, Sérgio de Faria Lopes

Capítulo 16: Reflorestamento de áreas da caatinga no território de identidade de irecê 118

Bruna da Silva Gomes, Andreza Nunes de Amorim, André de Oliveira Alves, Cláudio Roberto Meira de Oliveira

Capítulo 17: Disponibilidade e uso de espécies florestais nativas de importância sócioeconômica em comunidades rurais do agreste pernambucano 124 José Paulo Feitosa de Oliveira Gonzaga, Christianne Torres de Paiva, José Fernandes dos Santos Filho 


\section{SUMÁRIO}

Capítulo 18: Aperfeiçoando o procedimento padrão para a análise de demanda bíoquímica de oxigênio (dbo) da água no estado da Paraíba.

Nelson Medeiros de Assis Júnior, Eduardo Augusto da Silva Diniz, Marcelo da Silva Pedro

Capítulo 19: Análise estatística para identificação de tendências no regime de chuvas para o agreste meridional do estado de Pernambuco

Antônio Ricardo Santos de Andrade, Anízio Honorato Godoi Neto, Adiel Felipe da Silva Cruz, Erivaldo Laurentino da Silva, Anderson Santos da Silva

Capítulo 20: Análise cienciométrica sobre a dinâmica de serapilheira em ecossistemas semiáridos no Brasil

Brenna Hortins de Oliveira, Sérgio de Faria Lopes, Anderson Silva Pinto, Rubenice da Costa Correia, Larissa Barbosa da Silva5, Wanderleya Kelliane Lemos Pimentel

Capítulo 21: Avaliação e mensuração dos efeitos da regularização fundiária para o bairro Manoel Domingos - Pau dos Ferros/RN.

Hugo Leonardo Pontes Nunes, Cícero de França Neto, Almir Mariano de Sousa Júnior

Capítulo 22: Estudo da compreensão dos mineradores sobre os planos de recuperação de áreas degradadas pela extração de calcário laminado.

Letícia Lacerda Freire, Mariell Lima Costa, Marcos Antonio Pereira da Silva, Lidiane Marinho Teixeira, Viviane Brito Viana

Capítulo 23: Análise da qualidade da água do açude Epitácio Pessoa no município de Boqueirão - PB

Julyanna Damasceno Pessoa, Bruna da Silveira Guimarães, Josevania Rodrigues Jovelino, Kamila Freitas Porto, Kepler Borges França

Autores: 


\section{Capítulo 1}

Estratégias para a inserção de armazenamento energético em regiões semiáridas: Variabilidade $e$ aplicabilidade de tecnologias

\section{Caio Tácito Miranda Castro Bezerra de Melo}

\section{Daniel de Paula Diniz.}

Ana Katarina Pessoa de Oliveira

Monica Carvalho

Resumo: A utilização de energias renováveis no semiárido brasileiro não apresenta somente ganhos locais, mas também ganhos nacionais, devido ao aumento da diversificação da matriz energética nacional e ganhos globais, oriundos dos benefícios ambientais devido a menor emissão de poluentes. Porém, além das limitações relativas aos custos das tecnologias renováveis, deve-se considerar sua variabilidade na produção de energia, ao longo do dia e ao longo do ano. Este trabalho apresenta uma revisão sistemática de literatura para identificar estratégias para inserção de armazenamento energético em regiões semiáridas, demonstrando a viabilidade e aplicabilidade destas tecnologias no suporte à redução dos efeitos da intermitência e variabilidade sazonal das energias renováveis (sobretudo a solar e a eólica) em diversas possibilidades de aplicações. A revisão foi realizada com base em artigos publicados em periódicos científicos e publicações em anais de eventos, na base de dados Periódicos CAPES. Descritores específicos na língua inglesa foram aplicados, assim como seus sinônimos e correspondentes na língua portuguesa e espanhola, em combinações variadas, levando em consideração a importância de encontrar todos os estudos relacionados com o assunto disponível na literatura e que, além de obedecerem aos critérios adotados, apresentassem elevada qualidade metodológica. A estratégia de busca elaborada forneceu um total de 119 estudos. Após a triagem pela leitura dos títulos e resumos, 18 estudos foram considerados potencialmente elegíveis e lidos na íntegra pelos avaliadores. Ao término das análises, 11 artigos preencheram todos os critérios de inclusão para o estudo, sendo publicados entre os anos de 2003 e 2018 e desenvolvidos na Alemanha, Arábia Saudita, Austrália, Estados Unidos, Argélia e Brasil. Os resultados obtidos neste trabalho evidenciam que assim como ocorreu em outros países, a instalação de sistemas de armazenamento de energia associados a utilização de fontes alternativas renováveis, favorece a que estas fontes (abundantes nas regiões semiáridas, mas consideradas intermitentes) se tornem mais estáveis e contínuas e assim, mais competitivas em relação a energias fósseis e hidrelétricas.

Palavras-chave: Semiárido, Energias renováveis, Armazenamento elétrico, Armazenamento de energia. 


\section{INTRODUÇÃO}

A ocorrência de regiões semiáridas não é exclusividade do Brasil. Estas regiões caracterizam-se pela aridez do clima, precipitações irregulares no tempo e no espaço, e temperaturas elevadas (de acordo com a classificação climática de Köppen-Geiger referem-se às regiões BSh - clima semiárido quente e BSk clima semiárido frio) (MENDONÇA; DANNI-OLIVEIRA, 2017). 41,3\% de toda a superfície terrestre é constituída por terras áridas, semiáridas e subúmidas secas, e 7,7\% corresponde a desertos (NAÇÕES UNIDAS, 2018).

Segundo Andrade (2017), as regiões semiáridas do globo terrestre se caracterizam pelo déficit hídrico e por um elevado saldo positivo de energia solar. 0 nordeste brasileiro tem, adicionalmente, fatores determinantes específicos tais como solos rasos, alta demanda evaporativa, retirada da cobertura vegetal e organização social.

A inserção de energias renováveis no semiárido brasileiro não presenta somente ganhos regionais (independência da rede elétrica, por exemplo), já que a matriz energética nacional também se beneficia da contribuição, desconcentrando as fontes predominantes (hidrelétricas e termoelétricas). Desde um ponto de vista ambiental, maior produção de energia por meio de recursos renováveis está alinhada com as metas de redução de emissões de poluentes, para mitigar as mudanças climáticas e o aquecimento global. Porém antes de se introduzir a energia renovável, devem-se considerar técnicas e estratégias para gerenciamento de energia.

0 gerenciamento de energia é o uso eficiente da energia para maximizar lucros (reduzindo custos) e aumentar competitividade, enquanto atende às demandas energéticas. Isto pode ser alcançado por meio do ajuste e otimização de sistemas energéticos e seus procedimentos, tanto do lado da demanda quanto do lado do fornecimento. A Figura 1 mostra um resumo das estratégias para gerenciamento da energia.

Figura 1 Esquema simplificado para atividades de gerenciamento energético em cidades (adaptado de Carvalho e Millar, 2012).

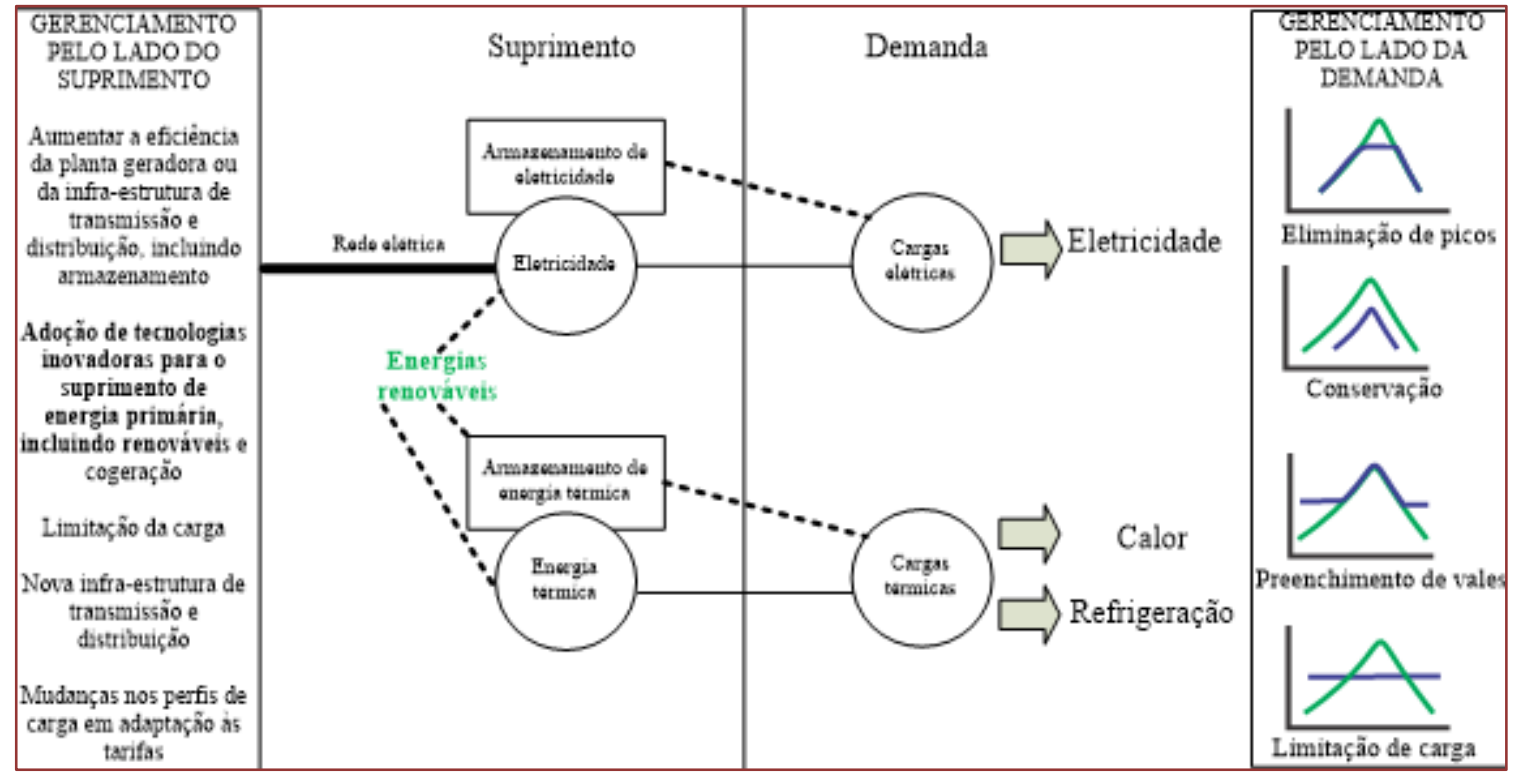

Os sistemas energéticos a base de recursos renováveis são peças-chave para apoiar o desenvolvimento sustentável e a proteção do clima. No entanto esta tarefa é intrinsecamente difícil: o grande desafio é como acomodar e lidar com a intermitência e variabilidade dos recursos renováveis. Além disso, a variedade de tecnologias disponíveis e combinações possíveis aumenta a complexidade na hora de sua instalação. As características de algumas fontes de energias renováveis, tais como a solar e eólica, dificultam sua compatibilização com as demandas dos sistemas de distribuição, já que nem sempre o pico de geração de energia solar fotovoltaica coincide com as horas ponta de utilização. Sistemas de armazenamento de energia podem ser incorporados a sistemas energéticos renováveis (ou instalados em redes de 
distribuição próximas) para regularizar seu fluxo e proporcionar confiabilidade (BARRETO; LEITE; GRIMONI, 2017).

0 armazenamento de energia não é útil somente quando energia renovável é introduzida no sistema de energia. 0 armazenamento de energia também é interessante para melhorar a estabilidade e a qualidade da eletricidade, bem como suavizar e regular mudanças repentinas de carga (ZUBI et al., 2018). Porém o foco deste artigo é o armazenamento de energia (térmica ou elétrica) como apoio à incorporação de energias renováveis em regiões semiáridas.

As regiões semiáridas são regiões nas quais a agricultura é um desafio e, portanto, o investimento em energias renováveis, como solar e eólica, pode contribuir na geração de emprego e renda no semiárido, por meio da instalação e manutenção das unidades produtivas e complexos geradores.

Já existem tecnologias comercialmente disponíveis (TESLA, 2018) para armazenamento elétrico e então é possível aproveitar completamente a produção de energia renovável (solar ou eólica, por exemplo). Ainda que a matriz energética do Brasil seja majoritariamente renovável, as termoelétricas ainda servem para atender às demandas-base de energia. A utilização de armazenamento de energia é uma saída importante para massificação da eletricidade renovável, podendo minimizar o acionamento das termoelétricas em momentos de necessidade e tornar nossa matriz elétrica ainda mais renovável.

\section{OBJETIVOS}

O objetivo deste trabalho é apresentar uma revisão sistemática de literatura, identificando estratégias para inserção de armazenamento energético em regiões semiáridas. A revisão foi realizada com base em artigos publicados em periódicos científicos e publicações em anais de eventos, na base de dados Periódicos CAPES.

\section{METODOLOGIA}

Trata-se de uma revisão sistemática de literatura com o interesse de identificar estratégias para inserção de armazenamento energético em regiões semiáridas.

Uma busca sistemática de artigos científicos publicados foi executada na base de dados Periódicos CAPES, por meio dos descritores: energy storage semiarid, energy store semiarid, electricity storage semiarid, electricity store semiarid, thermal storage semiarid, thermal store semiarid, assim como seus sinônimos e correspondentes na língua portuguesa e espanhola, em combinações variadas, levando em consideração a importância de encontrar todos os estudos relacionados com o assunto disponível na literatura e que, além de obedecerem aos critérios adotados, apresentassem elevada qualidade metodológica. Foram incluídos registros publicados até 28 de setembro de 2018.

\subsection{CRITÉRIOS DE INCLUSÃO}

Incluíram-se estudos que tiveram como objetivos avaliar o desempenho de armazenamento energético em sistemas de fornecimento de energia em regiões semiáridas, apresentar propostas de inclusão de tais sistemas em regiões semiáridas, e apresentar revisões sistemáticas sobre o tema. Foram selecionados estudos publicados em língua inglesa, portuguesa e espanhola. Não houve restrição quanto ao ano de publicação a fim de maximizar a identificação de literatura relevante.

\subsection{CRITÉRIOS DE EXCLUSÃO}

Foram excluídos da revisão artigos que avaliaram sistemas de conversão e fornecimento de energia para regiões distintas da semiárida, ou que não incluíssem armazenamento.

\subsection{ANÁLISE}

Inicialmente, foi realizada uma triagem a partir da análise dos títulos e resumos localizados na busca. Posteriormente, todos os estudos que se apresentaram pertinentes ao tema foram obtidos na íntegra e analisados separadamente. Por fim, os artigos analisados e selecionados pelos avaliadores, seguindo os 
critérios de inclusão e exclusão estabelecidos, foram incluídos na sistematização dos dados após reunião de consenso. As listas de referências de todos os artigos elegíveis foram consultadas, na tentativa de encontrar novos estudos para esta revisão.

\section{RESULTADOS E DISCUSSÃO}

A estratégia de busca elaborada forneceu um total de 119 estudos. Após a triagem pela leitura dos títulos e resumos, 18 estudos foram considerados potencialmente elegíveis e lidos na íntegra pelos avaliadores. Ao término das análises, 10 artigos preencheram todos os critérios de inclusão para o estudo: Schwarzer e Silva (2003); Hepbasli e Alsuhaibani (2011); Rahman, Rehman, Abdul-Majeed (2012); Ruddell, Salamanca e Mahalov (2014); Swarna et al. (2014); Boukelia et al. (2015); Araújo e Tapia (2016); Trannin (2016); Albiero et al. (2017); Gruber e Dalheimer (2018).

Os estudos selecionados foram publicados entre os anos de 2003 e 2018. Dentre estes, cinco foram realizados em países desenvolvidos (Alemanha, Arábia Saudita, Austrália, Estados Unidos), cinco em países em desenvolvimento (Argélia e Brasil) e um em escala global. Na continuação, serão apresentados brevemente cada estudo, juntamente com as particularidades de cada estrutura, e os parâmetros de desempenho, em ordem cronológica.

O trabalho de Schwarzer e Silva (2003) estudou sistemas solares para cozimento com e sem apoio de armazenamento térmico, para famílias e instituições no semiárido. Ao final, 250 unidades foram colocadas em testes, com coletores solares de placas planas e armazenamento térmico baseado em tanques com pedras que satisfizeram as necessidades energéticas adequadamente.

Hepbasli e Alsuhaibani (2012) apresentam o status atual e as expectativas de futuro da utilização da energia solar na Arábia Saudita. Contataram que apesar de estar localizada numa região desértica com radiação solar média de $2200 \mathrm{kWh} / \mathrm{m}^{2}$, ou seja, com grande potencial de aproveitamento em sistemas com intuito de minimizar os impactos ambientais substituindo a dependência do suprimento finito de combustíveis fósseis, há uma percepção predominante de que a energia renovável é largamente irrelevante nos horizontes de planejamento de médio e longo prazo do investimento industrial e de energia. Afirmam também que o uso do armazenamento de energia se torna fundamental em projetos de dessalinização (necessários em regiões semiáridas) baseados em processos térmicos como os que envolvem energia solar térmica, fotovoltaica, eólica e híbrida, a fim de proporcionar uma operação contínua ou semi-contínua independente das condições climáticas.

Rahman, Rehman e Abdul-Majeed (2012) apresentaram uma visão geral dos sistemas avançados de armazenamento de energia elétrica gerada por fontes de energia renováveis de acordo com as condições climáticas e a situação de demanda de fornecimento de energia na Arábia Saudita. Entre todos os parâmetros meteorológicos, a temperatura e a umidade relativa foram considerados os mais importantes para a eficiência e a vida útil da bateria e, portanto, devem ser consideradas ao selecionar uma bateria para fins de armazenamento de energia em regiões semiáridas. Com base em avaliações abrangentes de tecnologia, avaliação econômica e condições da Arábia Saudita, recomendou-se iniciar o trabalho de P\&D para melhorar ainda mais a tecnologia, bem como a economia local, visto que o armazenamento é o elo mais fraco do domínio da energia, mas é um elemento-chave para o crescimento das energias renováveis, além do quê, há uma quase total ausência de consciência pública da necessidade de sistemas de armazenamento de energia.

Ruddell, Salamanca e Mahalov (2014) analisaram as tecnologias a serem usadas para gerenciar a demanda elétrica em uma cidade quente e semiárida, a área metropolitana de Phoenix (E.U.A.). A simulação considerou a porção de ar condicionado da demanda elétrica durante uma onda de calor de verão, que seria transferida para horários fora do horário de pico usando a tecnologia de armazenamento térmico distribuído. Com as atuais taxas de renovação de novas construções, se todos os prédios novos ou reformados fossem equipados com sistemas de armazenamento de energia térmica frio, provavelmente levaria de 10 a 20 anos para atingir esse nível de penetração no mercado (sendo considerado um excelente potencial para de redução de demanda elétrica), onde o custo de capital da implementação precisaria ser compartilhado por concessionárias e clientes por meio de uma combinação de preços e descontos de eletricidade por tempo de uso.

Swarna et at. (2014) apresentam a análise de viabilidade para o clima semiárido e encontra os locais mais adequados na região semiárida, em particular a região Nordeste de Victoria (Austrália), para geração de energia renovável. Na análise econômica e ambiental, um modelo de hibridização foi considerado para investigarem as perspectivas de energia eólica e solar considerando o valor presente líquido (VPL), o custo de energia, além de considerar métricas de desempenho ambientais e emissão de gases do efeito 
estufa. Neste estudo os autores simplificaram as operações e não levaram em conta o armazenamento por meio de baterias, e sim, apenas o sistema de armazenamento indireto. Este sistema utiliza a própria rede da concessionária para receber a energia excedente da geração limpa e a converte em créditos ao cliente. Assim, concluiu-se que, este estudo pode ser usado pelas concessionárias para facilitar a integração de energia renovável em larga escala na rede, e a partir dos resultados de otimização e sensibilidade, fica evidente que a integração de energia renovável na rede, não apenas reduz a crise energética mundial, mas também reduz os custos de energia e as emissões de gases de efeito estufa, desempenhando um papel significativo no desenvolvimento de uma sociedade sustentável.

Boukelia et al. (2015) realizaram estudo que abordou a otimização de duas usinas de energia solar térmica parabólica na Argélia (maior país africano e localizado em área de extrema radiação solar), integrada com armazenamento térmico de energia e sistema de reserva de combustível. A primeira planta usa o Therminol VP-1 como fluido de transferência de calor no campo solar e a segunda planta usa sal fundido. A otimização foi realizada com o objetivo de minimizar o custo da eletricidade e maximizar o rendimento energético anual. 0 estudo de viabilidade propôs Tamanrasset como a melhor localização para a construção de uma central térmica solar parabólica com um baixo custo relativo e uma alta geração de energia anual (266 GWh), ratificando que os sítios argelinos semiáridos e áridos são adequados para a realização de plantas de geração de potência a partir da energia solar térmica concentrada com armazenamento de energia térmica e reserva de combustível integrados, devido principalmente às condições climáticas como baixa precipitação, abundância de terras planas não utilizadas próximas a redes de transmissão, redes rodoviárias e a abundância de sol.

Segundo Araújo e Tapia (2016), os sistemas de armazenamento de energia térmica aumentam o fator de capacidade das usinas de energia solar térmica, aumentando assim a confiabilidade desse aporte de fonte renovável. Desta forma, aplicaram o método de volume finito para modelar e simular um tanque de armazenamento de energia térmica para plantas de energia solar concentrada (ESC), que atingem temperaturas em torno de $600^{\circ} \mathrm{C}$, onde as análises foram realizadas com as condições ambientais do semiárido brasileiro (Petrolina - PE). De acordo com os autores, entre as energias renováveis, a energia solar térmica, tem grande potencial para o desenvolvimento de sistemas de armazenamento de energia térmica. Assim, pode gerar eletricidade durante períodos de nebulosidade e após o pôr do sol, uma alternativa que não está presente em parques eólicos (com a falta de vento) e painéis fotovoltaicos (na ausência de luz solar). 0 sistema proposto no estudo consiste no tipo calor sensível direto com dois tanques (mais comercialmente utilizado), utilizando o sal de nitrato de ópio $\left(60 \% \mathrm{NaNO}_{3} 40 \% \mathrm{KNO}_{3}\right.$ ) como material de armazenamento. Tal sistema apresentou eficiência de $96 \%$, sendo considerado satisfatório, se mostrando uma alternativa viável para aumentar o fator de capacidade de usinas solares. Assim, os autores afirmam que o armazenamento térmico é um dos pontos fortes da energia solar térmica e a compreensão dos mecanismos de transferência de calor é primordial para o desenvolvimento de novas tecnologias de armazenamento térmico. Com isso, a região nordeste do Brasil aparece com grande potencial de geração de energia através do uso de usinas de energia solar, bem como a aplicação de um sistema de armazenamento térmico na região mostrou-se termicamente viável devido a sua alta eficiência, sendo necessário ainda, realização de pesquisa econômica para a plena análise da viabilidade do sistema.

Trannin (2016) apresenta o caso da usina híbrida de Tacaratu - PE (maior complexo solar em operação no Brasil está localizado no semiárido pernambucano, operando integrado com geração eólica, gerando atualmente $340 \mathrm{GWh}$ por ano). 0 autor também discutiu as dificuldades, benefícios e perspectivas de projetos como este no futuro do semiárido brasileiro. Para acompanhar o expressivo aumento na demanda energética, se faz necessário ampliar a capacidade instalada do país, diversificando ainda mais a matriz energética brasileira. A integração de energia solar e eólica traz inúmeros benefícios como por exemplo, a maior estabilidade de produção, redução dos efeitos da variação climática, complementariedade (já que a maior produção solar é durante o dia e a maior produção eólica é à noite), utilização da mesma subestação e linha de transmissão, menor impacto ambiental, além do aumento da geração de empregos, principalmente no momento da construção da usina, em regiões de baixa empregabilidade. Além disso, a publicação mostra que os avanços nas tecnologias de armazenamento e o aumento da inteligência dos sistemas elétricos no mundo permitem que uma maior penetração de fontes renováveis seja feita sem prejudicar a segurança energética do país.

Albiero et al. (2017) propuseram uma usina híbrida constituída por um sistema de geração de potência eólica, um sistema de geração de potência solar e um sistema de geração de potência química por meio de biogás. 0 projeto considerou as condições climáticas e sociais de oito cidades localizadas nas oito macrorregiões do estado de Ceará, no semiárido brasileiro, sendo apresentados os cálculos de geração de energia e de custo de investimento no projeto. A usina projetada atendeu às demandas de energia de 
propriedades de 20 hectares e gerou uma energia excedente representativa em quatro dos oito municípios estudados. Neste caso, a forma de armazenamento da energia excedente que foi o armazenamento indireto (através do uso da própria rede elétrica da concessionária, utilizando o formato de crédito na tarifa de energia elétrica) ao invés de utilizar armazenamento pelo uso de baterias chumbo-ácido que, segundo os autores, é onerosa e prejudicial ao meio ambiente

Para Gruber e Dalheimer (2018), dos conceitos de fornecimento de energia renovável, um grande desafio é o armazenamento de energia para mobilidade e tecnologia de balanceamento da rede para controle de frequência e tensão. Os autores analisaram o potencial do óleo vegetal puro de Jatropha (planta tropical nativa das Américas, e não comestível) cultivada de forma sustentável em terras semiáridas como contribuintes para um mix de energia renovável, principalmente para os países em desenvolvimento e mercados emergentes da África, Ásia e América Latina. Segundo os autores, a semente analisada parece apresentar as melhores condições para servir como uma estratégia mundial para produzir biocombustíveis sustentáveis para mobilidade e eletricidade, enquanto combate à desertificação, mudanças climáticas, pobreza e migração, principalmente em regiões semiáridas.

Os resultados obtidos neste trabalho evidenciam que assim como ocorreu em outros países, a instalação de sistemas de armazenamento de energia associados à utilização de fontes alternativas renováveis, favorece a que estas fontes se tornem mais estáveis e assim, mais competitivas em relação a energias fósseis e hidrelétricas.

Além da perspectiva econômica, associada aos custos monetários envolvidos nas instalações de sistemas energéticos renováveis, pouco a pouco as pesquisas já começam a considerar critérios ambientais no momento de projetar um sistema, além de tendências climáticas (FONSECA; CARVALHO, 2019). As emissões de gases de efeito estufa foram o foco do trabalho de Carvalho et al. (2019), que verificou o potencial de mitigação das mudanças climáticas associado à geração de bioeletricidade com bagaço de cana. Delgado et al. (2018) analisou o potencial de instalação de caldeiras a biomassa, Araújo et al. (2018) verificou as vantagens ambientais de se utilizar resíduo de poda urbana para gerar eletricidade, Neves et al. (2018) confirmou as vantagens ambientais de se utilizar biossólido industrial para fertilizar capim elefante (para uso energético), e Grilo et al. (2018) verificou que o fornecimento de energia solar fotovoltaica minimiza emissões de carbono. Espera-se que a consideração de critérios ambientais possa extrapolar os benefícios ambientais confirmados pelas pesquisas citadas para outras regiões. Conclui-se que a difícil situação das populações que vivem em regiões semiáridas pode ser atenuada pelos resultados de pesquisas científicas e tecnológicas.

\section{CONCLUSÕES}

Este trabalho apresentou uma revisão sistemática de literatura com o interesse de identificar estratégias para inserção de armazenamento energético em regiões semiáridas, demonstrando a viabilidade e aplicabilidade destas tecnologias no suporte à redução dos efeitos da intermitência e variabilidade sazonal das energias renováveis (sobretudo a solar e a eólica) nos mais diversos setores da região do semiárido nacional.

A difícil situação das populações que vivem em regiões semiáridas pode ser atenuada pelos resultados de pesquisas científicas e tecnológicas que mostram a viabilidade de projetos de geração de energia térmica, geração de energia elétrica a partir de sistemas híbridos, e dessalinização de água. Experiências de sucesso em outras regiões semiáridas do mundo podem ser estendidas e adaptadas para o Nordeste Brasileiro, evidenciando que é possível melhorar as condições de vida em situações climáticas adversas.

A estratégia de incorporar centrais produtoras de energia solar e eólica no semiárido está direcionada a tentar garantir um futuro sustentável, que pode culminar no aumento da renda na região, com a promoção de uma economia socialmente justa e menos vulnerável aos efeitos das secas associada à variabilidade natural do clima e de suas alterações.

Atingir o desenvolvimento sustentável é uma meta que hoje é amplamente vista como importante para a opinião pública mundial. Neste contexto, a utilização de recursos energéticos renováveis, como a energia solar, geotérmica e eólica, parece ser uma das formas mais eficientes e eficazes de atingir esta meta, mas em combinação com armazenamento energético. 


\section{FOMENTO}

Os autores agradecem o apoio do Conselho Nacional de Desenvolvimento Científico e Tecnológico (Bolsa de Produtividade em Pesquisa, nº 307394/2018-2) e à Coordenação de Aperfeiçoamento de Pessoal de Nível Superior pela bolsa de doutorado.

\section{REFERÊNCIAS}

[1] Albiero, D.; Praciano, A. C.; Vogt, H. H.; Monteiro, L. A.; Feitosa, E. O. Sistema híbrido renovável de geração de energia elétrica para o semiárido. Conexões Ciências e Tecnologias, Fortaleza, v. 11, n. 1, p. 43-48, 2017.

[2] Andrade, E. M. A floresta tropical seca, caatinga: as certezas e incertezas das águas. Revista de investigación multidisciplinar, v. 12, p. 11-20, 2017.

[3] Araújo, A. K. A.; Tapia, G. I. M. Modeling and simulation of a two tanks sensible heat storage system in the Brazilian semiarid region. In: Brazilian Congress OF Thermal sciences And Engineering, 16., Vitória, 2016. Vitória: [s.n.], 2016.

[4] Araújo, Y. R. V. et al. Carbon footprint associated with four disposal scenarios for urban pruning waste. Environmental Science and Pollution Research, v. 25, n. 2, p. 1863-1868, 2018.

[5] Barreto, G. A.; Leite, B. M.; Grimoni, J. A. B. Armazenamento de Energia. In: Moreira, J. R. S. (Org.). Energias Renováveis, Geração Distribuída e Eficiência Energética. 1a Edição. Rio de Janeiro: Grupo GEN - LTC, 2017.

[6] Boukelia, T. E. et al. Optimization, selection and feasibility study of solar parabolic trough power plants for Algerian conditions. Energy Conversion and Management, v. 101, n. 1, p. 450-459, 2015.

[7] Carvalho, M.; Millar, D. L. Concept development of optimal mine site energy supply. Energies, v. 5, n. 11, p. 4726-4745, 2012.

[8] Carvalho, M. et al. Carbon footprint of the generation of bioelectricity from sugarcane bagasse in a sugar and ethanol industry. International Journal of Global Warming, v. 17, n. 3, p. 235-251, 2019.

[9] Delgado, D. B. M. et al. Analysis of Biomass-fired Boilers in a Polygeneration System for a Hospital. Frontiers in Management Research, v. 2, n. 1, 2018.

[10] Fonseca, L. F. S.; Carvalho, M. Impacto das tendências climáticas na produção de energia por fontes renováveis. In: Fórum Latino-Americano de Engenharia e Sustentabilidade, 5., João Pessoa, 2019. Anais... João Pessoa: [s.n.], 2019.

[11] Grilo, M. M. S. et al. Carbon footprints for the supply of electricity to a heat pump: Solar energy vs. electric grid. Journal of Renewable and Sustainable Energy, v. 10, n. 2, p. 023701, 2018.

[12] Gruber, G. Dalheimer, B. Energy storage and balancing power for 100\% renewable energy hybrid systems: the potential of jatropha for rural electrification in hot semi-arid areas. In: European Biomass Conference And Exhibition, 26., 2018, Copenhagen. Copenhagen: [s.n.], 2018.

[13] Hepbasli, A.; Alsuhaibani, A. A key review on present status and future directions of solar energy studies and applications in Saudi Arabia. Renewable and Sustainable Energy Reviews, v. 15, n. 9, p. 5021-5050, 2011.

[14] Mendonça, F.; Danni-Oliveira, I. M. Climatologia: noções básicas e climas do Brasil. Oficina de textos, 2017.

[15] Nações Unidas. 2018. United Nations Decade for Deserts and the Fight Against Desertification. Why Now? Disponível em: <www.un.org/en/events/desertification_decade/whynow.shtml>. Acesso em 02 abr 2019.

[16] Neves, T. I. et al. Environmental evaluation of the life cycle of elephant grass fertilization-Cenchrus purpureus (Schumach.) Morrone-using chemical fertilization and biosolids. Environmental monitoring and assessment, v. 190, n. 1, p. 30, 2018.

[17] Rahman, F.; Rehman, S.; Abdul-Majeed, M. A. Overview of energy storage systems for storing electricity from renewable energy sources in Saudi Arabia. Renewable and Sustainable Energy Reviews, v. 6, n. 1, p. 274-283, 2012.

[18] Ruddell, B. L.; Salamanca, F.; Mahalov, A. Reducing a semiarid city's peak electrical demand using distributed cold thermal energy storage. Applied Energy, v. 134, n. 1, p. 35-44, 2014.

[19] Schwarzer, K.; Silva, M. E. V. Solar cooking system with or without heat storage for families and institutions. Solar Energy, v. 75, n. 1, p. 35-41, 2003.

[20] Swarna, K. S. V.; Shafiullah, G. M.; 00, A. M. T.; Stojcevski, A. Prospects of Renewable Energy in Semi-Arid Region. Journal of Power and Energy Engineering, v. 2, p. 26-35, 2014.

[21] Tesla. Powerwall. 2018. Disponível em: <https://www.tesla.com/powerwall> Acesso em 02 abr 2019. 
[22] Trannin, M. Desafios e oportunidades para a geração de energia elétrica por fontes renováveis no brasil: estudo de caso sobre a usina híbrida de Tacaratu (PE). Boletim Energético - FGV, abril, 2016. Disponível em:

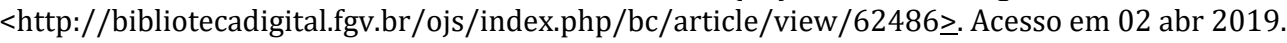

[23] Zubi, G. et al. The lithium-ion battery: State of the art and future perspectives. Renewable and Sustainable Energy Reviews, v. 89, p. 292-308, 2018. 


\title{
Capítulo 2
}

\section{Avaliação dos impactos ambientais gerados pela pequena mineração no município de Picuí:PB}

\author{
Ailma Roberia Souto de Medeiros \\ Jaqueline de Souza Dantas \\ Paulo Sales da Costa Barros \\ Ligia Mara Gonzaga
}

Resumo: A mineração é um dos setores básicos da economia do país que tem como seu alvo principal a extração de minerais para empresas, indústrias e até mesmo para a sobrevivência de garimpeiros. Entretanto, uma grande quantidade de impactos ao meio ambiente é gerada nos processos de extração e beneficiamento mineral. 0 município de Picuí-PB que se localiza na mesorregião da Borborema e microrregião do Seridó paraibano existe possui um número considerado de garimpos que extraem minérios, trazendo impactos ambientais negativos para o meio ambiente, pelo fato desses recursos não são renováveis. 0 objetivo deste trabalho é fazer uma avaliação dos impactos ambientais provocados pela atividade garimpeira no referido município. 0 procedimento metodológico para esta pesquisa obedeceu às seguintes etapas: pesquisa bibliográfica, checklist, como método de avalição de impactos ambientais, aplicado in loco em seis garimpos nos arredores de Picuí. A pesquisa visou diagnosticar impactos ambientais, na tentativa de procurar alternativas para minimizá-los, com a promoção e desenvolvimento de iniciativas sustentáveis no município. Foi verificado que a mineração é causadora de uma série de impactos negativos, principalmente impactos visuais, poluição, retirada da vegetação, deformação da topografia, entre outros. 0 grande risco de acidentes devido a não utilização de técnicas adequadas a extração destes bens minerais afeta saúde dos garimpeiros, e, mesmo diante desta situação, a atividade garimpeira ainda é única fonte de renda de muitas famílias. No intuito de minimizar as questões acima elencadas, uma capacidade dos trabalhadores deste setor faz-se necessária, a fim de que eles aprendam a utilizar melhor os recursos, bem como cuidarem melhor do meio ambiente, incentivando-os ao uso de Equipamento de Proteção Individual, para prevenir alguns acidentes.

Palavras-Chave: Mineração, Impactos ambientais, Checklist. 


\section{INTRODUÇÃO}

A mineração é considerada uma das atividades econômicas mais antigas de produzir riquezas pela humanidade. Esta é uma atividade básica, que trabalha com recursos naturais não renováveis. Como tal, é o ponto de partida de cadeias industriais de vários segmentos. Sabe-se também que esta atividade é de fundamental importância para a sobrevivência humana, pois é produtora da maioria dos insumos básicos.

0 município de Picuí-PB encontra-se localizado na mesorregião da Borborema e microrregião do Seridó paraibano. Geologicamente, está inserido na Província Pegmatítica da Borborema-Seridó, de grande diversidade mineralógica, onde há ocorrências de uma grande variedade de espécies minerais.

Sendo o semiárido um clima desfavorável à atividade agrícola, devido a longos períodos de estiagem, no município de Picuí-PB, uma das principais atividades econômicas é a mineração (LIMA, 2013). A maior parte desta extração é feita através da lavra garimpeira, onde os trabalhos são realizados com a falta de conhecimentos técnicos sobre os perigos ao os quais estão expostos. Este método de lavra é caracterizado por uma exploração predatória, rudimentar e agressiva ao meio ambiente, não havendo a utilização de técnicas.

Segundo Oliveira Jr. (1999) e Bitar (1997) as atividades extrativas pela mineração alteram drasticamente o relevo, levando à destruição do solo, da vegetação e, consequentemente, da fauna. Nas pequenas minerações, as superfícies rochosas, de grande declive e sem solo, dificilmente propiciam a fixação de espécies vegetais e, consequentemente, a regeneração espontânea da vegetação. Assim impactos decorrentes da acumulação de grandes massas de escombros e da dispersão das poeiras nas regiões envolventes são também aspectos potencialmente preocupantes.

A atividade mineradora e o garimpo promovem impactos diretos na natureza, levando a deterioração do ambiente. Tanto o garimpo quanto a mineração extraem recursos que se encontram no solo ou no subsolo, de onde são retirados diversos tipos de minérios, no caso deste município, são explorados os chamados minerais industriais (feldspato, mica, quartzo e gemas). A atividade de extração mineral na area estudade é feita principalmente da forma mais simples de mineração, o GARIMPO.

Diante disso, o objetivo deste trabalho foi fazer uma avaliação dos impactos ambientais causados pela pequena mineração no município de Picuí - PB, bem como indicar alternativas para desenvolvimento sustentável local, decorrendo de um projeto de pesquisa desonvolvido no IFPB Campus Picuí com alunos do curso técnico integrado ao ensino médio em geologia.

\section{REVISÃO BIBLIOGRÁFICA}

\subsection{CARACTERIZAÇÃO DA ÁREA}

Este item tratará de uma apresentação da área de estudo onde o trabalho foi Realizado, contendo sua localização, aspectos socioeconômicos e geologia regional.

\section{- Localização}

O município de Picuí-PB está localizado na Mesorregião da Borborema e Microrregião Seridó Oriental do estado da Paraíba. Limitada ao Norte com Campo Redondo (RN) e Coronel Ezequiel (RN), Leste com Nova Floresta (PB) e Cuité (PB), Sul com Pedra Lavrada (PB), Nova Palmeira (PB), Oeste com Carnaúba dos Dantas (RN) e Frei Martinho (PB). Na Figura 1 observa-se a localização do município de Picuí-PB, no estado da Paraíba. 


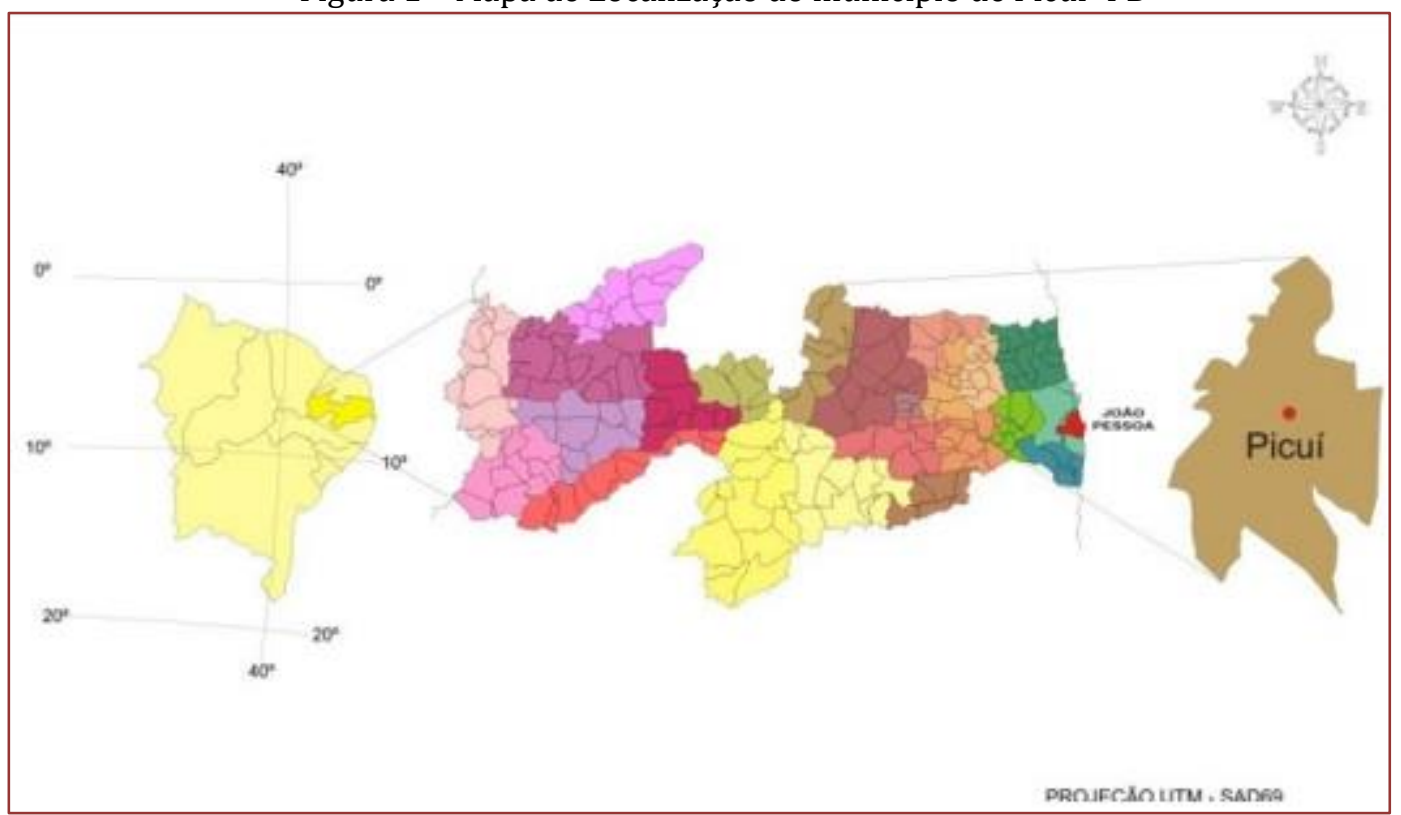

Fonte: Francisco et al., 2011

O acesso ao município se dá a partir de João Pessoa, através da rodovia federal BR-230, em trecho de $191 \mathrm{~km}$ até a cidade de Soledade, passando por Campina Grande. A partir da cidade de Soledade segue-se pela rodovia estadual PB-177, para norte, em trecho de $90 \mathrm{~km}$ até chegar à cidade de Picuí-PB, sede do município.

\section{- Aspectos Socioeconômicos}

Segundo o IBGE, a população estimada do município de Picuí-PB no ano de 2017 era de 18.222 pessoas. Em 2015, o salário médio mensal era de 1.9 salários mínimos. A proporção de pessoas ocupadas em relação à população total era de $8.7 \%$, entre os quais $12,120(66,5 \%)$ habitantes residem na zona urbana e $6,102(33,5 \%)$ habitantes na zona rural. A densidade demográfica é de $24,5 \mathrm{hab} / \mathrm{km} 2$. De sua população total, 8.953 são homens e 9.269 mulheres, com área territorial de $661,657 \mathrm{~km}^{2}$. A população de 10 anos ou mais alfabetizadas é de 12.995. O município possui o Índice de Desenvolvimento Municipal de 0,608 (IBGE, 2017).

Em 2010, das pessoas ocupadas na faixa etária de 18 anos ou mais diziam respeito a 40,54\% que trabalhavam no setor agropecuário, $1,76 \%$ na indústria extrativa, $7,74 \%$ na indústria de transformação, $6,19 \%$ no setor de construção, $1,15 \%$ nos setores de utilidade pública, $11,12 \%$ no comércio e $30,42 \%$ no setor de serviços dados do ultimo senso realizado pelo IBGE. Porém, nos últimos anos pode ter havido algumas mudanças devido aos fatores climáticos, pois, o município vem passando por um longo período de estiagem de, aproximadamente, seis anos.

- Geologia

Geologicamente, o município de Picuí-PB está localizado na Província Borborema pertencente ao Grupo Seridó. As rochas predominantes na formação da província Borborema são biotita-xistos granatíferos, biotitamuscovita-xistos, xistos filitosos e clorita-sericita-xistos, com intrusões pegmatíticas (Figura 2). A importância econômica desta formação está nas lentes intercaladas de calcário cristalino, sendo a maioria relacionada a tactitos scheelitíferos (SANTOS et al., 2002) 
Figura 2 - Mapa Geológico do Município de Picuí-PB.

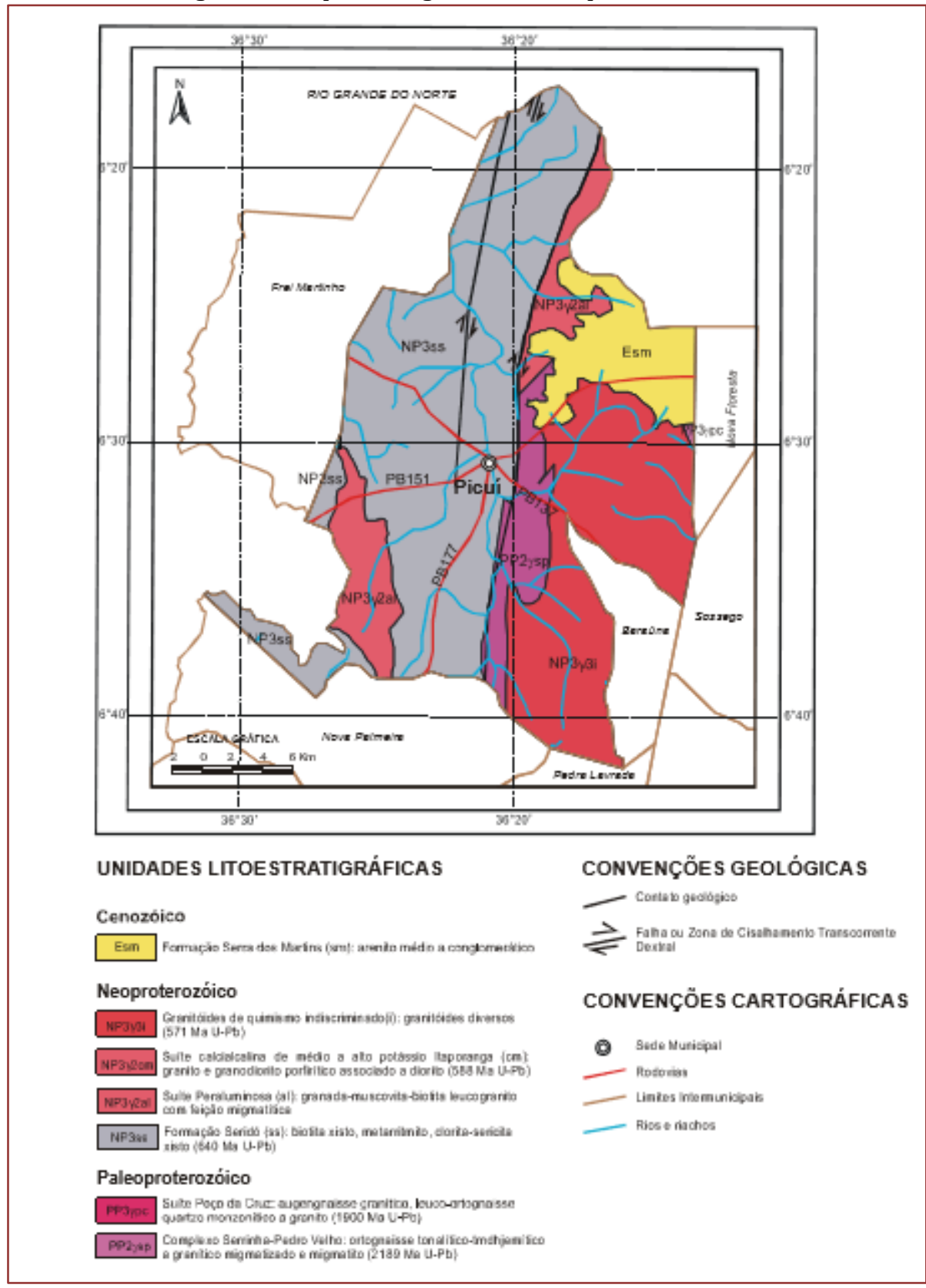

Fonte: CPRM, 2015.

De acordo com Silva et al., (2010), a Província Pegmatítica da Borborema é composta por pegmatitos graníticos, de idade Brasiliana (Neoproterozóico), estão encaixados principalmente em biotita-xistos da Formação Seridó e em quartzitos e metaconglomerados da Formação Equador. Os pegmatitos da Província Pegmatítica da Borborema foram divididos em dois principais grupos, chamados de homogêneos e heterogêneos.

A Província da Borborema é de grande importância por conter importantes depósitos de scheelita e de pegmatitos mineralizados (SANTOS et al., 2002).

\subsection{MINERAÇÃO}

A vocação mineral do município Picuí-PB foi descoberta em 1941, por técnicos americanos instalados na Barreira do Inferno, em Natal - RN, que deram início a uma planejada exploração da área para a retirada de minérios adequados a fabricação de artefatos bélicos. Segundo Vasconcelos (2004) o início da formação 
do meio mineral em Picuí-PB caracterizou-se principalmente pela exploração dos minerais: tantalita, berilo e urânio, para atender, sobretudo à indústria bélica americana.

Com o final da Segunda Guerra Mundial (1945) a mineração em Picuí-PB começa a ganhar um novo formato de exploração, caracterizada, então, pela presença de grandes empresas em busca de minerais para atender a indústria dos eletroeletrônicos com a exploração da mica moscovita. Em seguida, o setor da construção civil, com a exploração dos feldspatos, ambos utilizados na fabricação de cerâmicas e porcelanatos, o que permanece até os dias atuais.

0 processo de extração adotado é geralmente rudimentar e predatório, com perdas consideráveis na produção, decorrentes da ausência de uma pesquisa mineral sistemática, e da falta de planejamento de extração e do uso de equipamentos precários e mal dimensionados. Além do baixo nível educacional dos garimpeiros, o amadorismo administrativo com implicações na disponibilidade de peças para reparo, manutenção e reposição de motores e bombas e a falta de suporte técnico. Esses aspectos implicam uma utilização predatória e não sustentável, do ponto de vista técnico e econômico, da reserva mineral (KRÜGER, 2009).

\subsection{IMPACTOS AMBIENTAIS}

Pela definição de Tommasi (1993), impacto ambiental é entendido como qualquer alteração física ou funcional em qualquer dos componentes ambientais. Essa alteração pode ser qualificada e, muitas vezes, quantificada. Pode ser favorável ao ecossistema ou à sociedade humana.

As principais alterações ambientais causadas pela mineração podem ser resumidas em: supressão de áreas de vegetação, reconfiguração de superfícies topográficas, impacto visual, aceleração de processos erosivos, aumento da turbidez e assoreamento de corpos d'água, emissão de gases e partículas no ar, ruídos, além da propagação de vibrações no solo (BITAR, 1997).

Deve-se analisar todos os impactos decorrentes separadamente, tanto da área diretamente afetada assim como a comunidade que reside no seu entorno. Em cada uma das etapas de exploração ocorre um impacto ambiental na região próxima à pedreira. A intensidade desses impactos depende muito do compromisso da empresa responsável pelas áreas mineradas em adotar medidas que otimizam a extração e minimizam os efeitos no meio ambiente e na população.

Além disso, segundo Bacci (2006), outros setores relacionados à mineração, como o administrativo e a oficina, também são responsáveis por impactos ambientais. A classificação dos impactos que as pedreiras podem causar dividem-se em duas classes: os impactos positivos e os impactos negativos (MECHI, 1999).

Os impactos positivos relacionados a uma mineração, como observado por Mechi (1999), são de teor socioeconômico, uma vez que focam no desenvolvimento econômico e regional, na arrecadação de tributos, além da geração de empregos e melhoria na renda.

\subsection{AVALIAÇÃO DE IMPACTOS AMBIENTAIS}

As diversas formas existentes para avaliação do impacto ambiental têm provocado grandes debates científicos. Há que se considerarem as limitações do conhecimento científico no estabelecimento dos impactos potenciais, aspectos como subjetividade nas análises ou diferenças entre indicadores e impactos (SÁNCHEZ, 2006).

Barbieri (2004), em seu estudo sobre Avaliação de Impacto Ambiental (AIA), define o objetivo da AIA enquanto instrumento de política ambiental como sendo o de tornar viável o desenvolvimento em harmonia com o uso dos recursos naturais e econômicos. Portanto, poderia ser encarada como ciência e arte que reflete as preocupações com os aspectos técnicos que fornecem subsídios à tomada de decisão, considerando as vantagens e desvantagens de uma proposta em sua dimensão econômica, social e ecológica.

A Avaliação de Impacto Ambiental (AIA) é abordada enquanto processo de avaliação dos efeitos ambientais, econômicos e sociais, que podem advir da implantação de atividade antrópicas (IBAMA, 1995).

Portanto, a legislação brasileira vincula a utilização da AIA aos sistemas de licenciamento de órgãos estaduais de controle ambiental para atividades poluidoras ou mitigadoras do meio ambiente, em três versões a serem requeridas pelos responsáveis dos empreendimentos, a saber: Licença Prévia (LP) - é 
utilizada na fase preliminar do projeto, contendo requisitos básicos para localização, instalação e operação, observando-se os planos municipais, estaduais e federais de uso do solo; Licença Instalação (LI) - autoriza o início da implantação, de acordo com as especificações constantes no projeto executivo aprovado; Licença de Operação (LO) - autoriza, após verificação, o início das atividades licenciadas e o funcionamento de seus equipamentos descontrole de poluição.

\subsection{MEDIDAS MITIGADORAS}

Os impactos ambientais causados pelo homem no meio são constantes. As medidas mitigadoras são ações que visem à redução ou eliminação dos impactos negativos oriundos da implantação, operação, manutenção ou, até mesmo, desativação de determinado empreendimento. Os órgãos ligados à proteção do meio ambiente criam mecanismos e diretrizes.

Essas medidas são aplicadas com o auxilio governamental e fazem parte das leis específicas que regem a utilização de ambientes naturais. As Medidas Mitigatórias funcionam ainda como parâmetro para avaliar danos que venham a ser provocados por empresas que realizem suas explorações em área destinada à preservação ambiental ou se estas, de alguma maneira, ultrapassarem os limites estabelecidos para as suas atividades.

De acordo com o art. $6^{\circ}$, inciso III e art. $9^{\circ}$, inciso VI da Resolução CONAMA $n^{\circ} 1 / 1.986$, as medidas compensatórias diferem, essencialmente, das medidas mitigadoras. As medidas mitigadoras são aquelas estabelecidas antes da instalação do empreendimento, e visam à redução dos efeitos provenientes dos impactos ambientais negativos gerados por tal ação.

Para definir essas medidas, as avaliações devem ser executadas juntamente aos demais profissionais envolvidos na elaboração dos projetos do empreendimento, a fim de obter soluções viáveis para amenizar os danos ambientais. Já as medidas compensatórias são aplicadas para compensar, de alguma forma, os prejuízos e danos ambientais efetivos advindos da atividade modificadora do ambiente.

Os tipos de Medidas Mitigatórias, segundo o IBAMA: Medidas mitigadoras preventivas; Medidas Mitigadoras Corretivas; Medidas Mitigadoras Compensatórias e Medidas Potencializadoras (ZEFERINO, 2018).

\section{METODOLOGIA}

0 procedimento metodológico foi desenvolvido em duas etapas:

\subsection{COLETA DOS DADOS}

A coleta de dados foi realizada a partir de dois procedimentos: pesquisa bibliográfica, a fim de definir conceitos que possibilitem a compreensão da realidade social como dado científico e visitas aos moradores de regiões do município afetadas pela atividade mineradora. Após os primeiros contatos com os dados acerca dos impactos ambientais perceptíveis em decorrência da atividade mineradora foram realizadas visitas em campo para determinação desses impactos, usando como método de avaliação de impacto ambiental o checklist.

A metodologia de Avaliação através do checklist ou listagem de controle consiste de uma lista de fatores ambientais que podem ser afetados pelo empreendimento, a ser utilizada para uma avaliação rápida dos impactos ambientais. Tem como vantagens ser um método de fácil e simples aplicação, fácil de implementar para não especialistas e é considerado uma boa ferramenta para estudo de campo (SÁNCHEZ, 2006). 0 checklist foi elaborado durante a pesquisa.

\subsection{DA ANÁLISE DOS DADOS}

Os dados levantados nas visitas usando o checklist descritivo, que visa detectar os principais impactos negativos da atividade mineradora local:

- Supressão da vegetação;

- Alteração na topografia;

- Deposição de estéril; 
- Sucatas dispersas sem controle;

- Acumulo de lixo doméstico sem controle;

- Alteração da paisagem;

- Poluição do solo;

- Poluição sonora e vibração;

- Processos erosivos;

- Contaminação das águas

- Poluição Atmosférica

- Deslocamento da fauna;

\subsection{RESULTADOS E DISCUSSÃO}

Após um vasto levantamento bibliográfico a fim de compreender a situação ambiental e social que seria encontrada em campo, em seguida formulou-se o checklist que foi utilizado para indeficação de impactos ambientais. Logo após iniciou-se o trabalho de campo nos garimpos localizados nos arredores do municipio de Picui-PB Foram visitados seis garimpos, a seleção das áreas visitados se deu através da proximidades entre as áreas, como também da autorização concedida para entrar nestas áreas.

O garimpo Cova do Negro encontra-se ativo onde há extração de feldspato com lavra a ceú aberto, no momento da visita foi possivel indentificar atraves do checklist os seguintes impactos ambientais: supressão da vegetação, alteração na topografia, deposição de esteril, acumulo de lixo, deslocamento de fauna, alteração na paisagem, risco de desmoronamento, contaminação do solo por hidrocarbonetos e assoriamento de riacho.

Dentre todos os danos encontados no local os que mais nos chamou anteram foram o risco eminente de acidente, onde já havia ocorrido um grande desmoronanmento causado por um talude negativo, a contaminação por hidrocarboneto causada por vazamento em maquinas usadas na lavra e o assoriamento de um riacho. Na Figura 3 é possivel observar alguns dos impactos ambientais detectados neste garimpo.

Figura 3:Impactos ambientais identificados no garimpo Cova do Negro (A) Assoreamento do riacho; (B) Contaminação do solo por hidrocarbonetos; (C) Deposição de lixo aleatoriamente e (D) Desmoronanmento causado por um talude negativo.

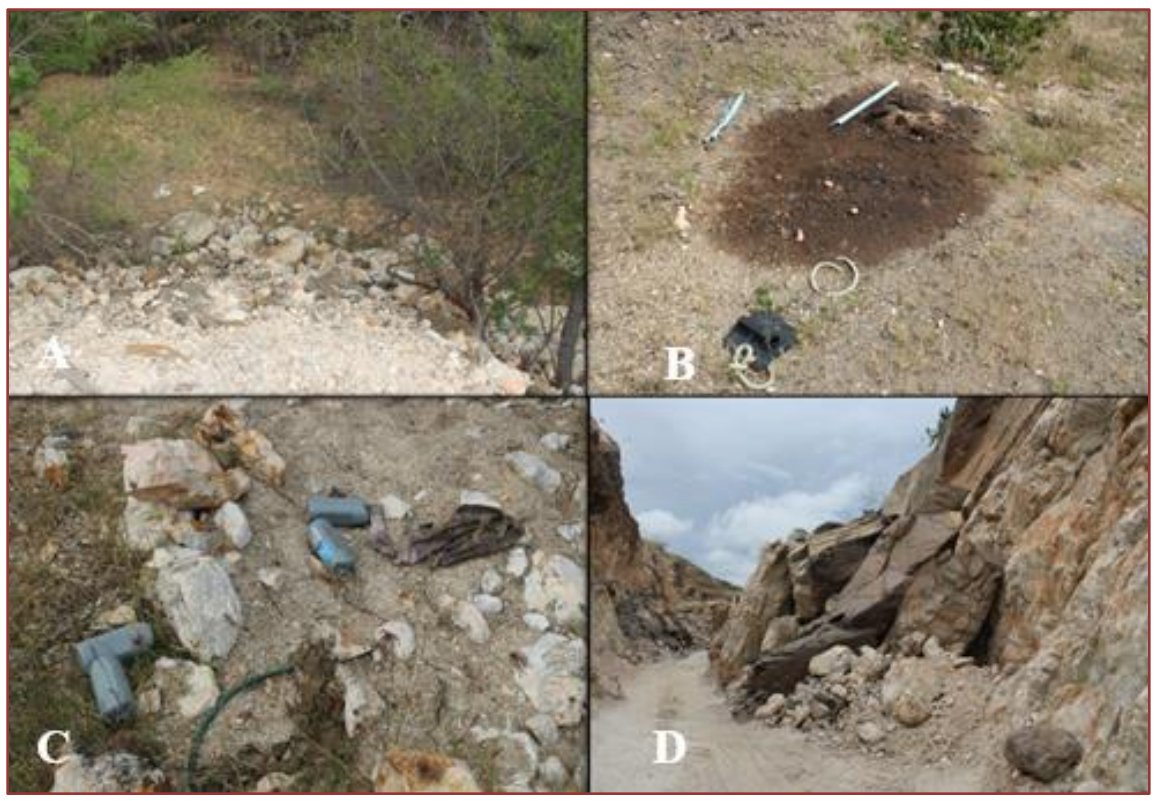

Fonte: Dados da pesquisa. 
Figura 4: Impactos ambientais identificados no garimpo Alto do Cuscuz. (A) Deposição de estéril; (B) Risco de desmoronamento; (C) Frente de Lavra e (D) Deposição de estéril

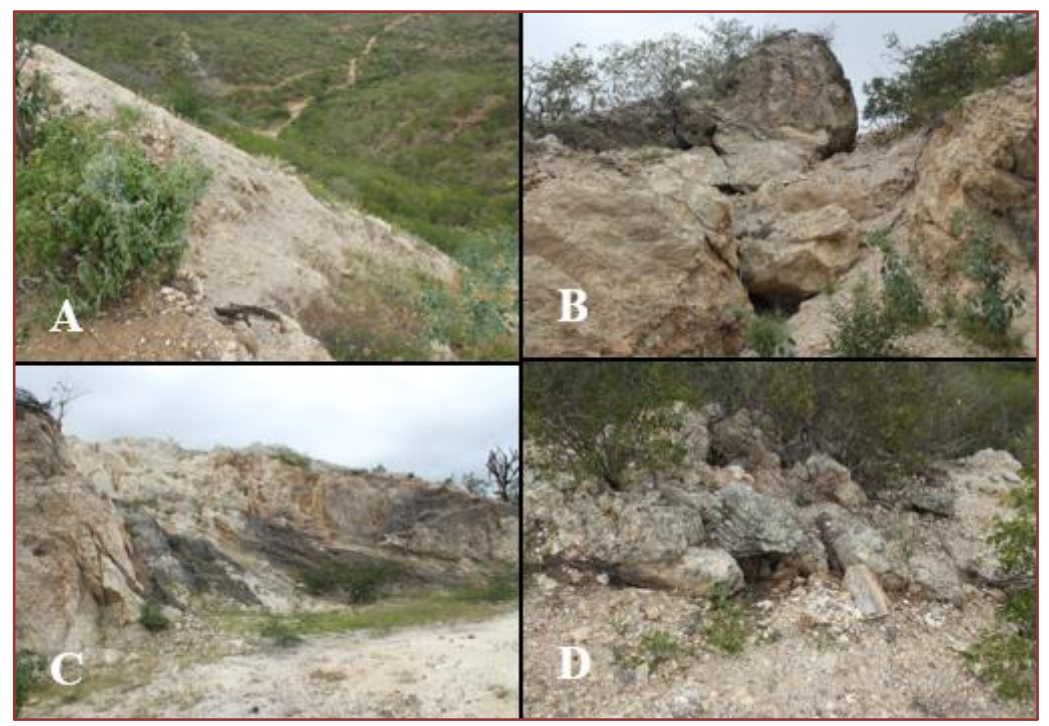

Já o garimpo Alto do Cuscuz encontra-se inativo, a extração de feldspato com lavra a céu aberto, foram observados os impactos ambientais: Supressão da vegetação, alteração na topografia, deposição aleatória de estéril, acúmulo de lixo, processos erosivos, perigo de desmoronamento e deslocamento de fauna (Figura 4). 0 garimpo é situado em uma zona de declive e foi possivel observar que parte das pilhas de estéril estava desmorando pela encosta.

O garimpo Saco do Cordeiro estava inativo na data da visita. Neste garimpo, a extração é realizada através da lavra subterrânea. Também detectou-se alguns impactos como: supressão da vegetação, alteração na topografia (causada pela deposição de estéril), acúmulo de lixo, processos erosivos, risco eminente de desmoronamento. Na Figura 5 é possivel observar esses impactos.

Por se tratar de uma mineração subterrânea, os impactos visuais são menores. Não foi possivel analisar impactos dentro da mina, pois não continha iluminação e havia um risco eminente de desmoronamento. Ao andar pelo terreno observou-se grande deposiçao de estéril.

Figura 5: Impactos ambientais identificados no garimpo Saco do Cordeiro. (A) Abertura de entrada da mina; (B) Deposição de estéril; (C) Supressão da vegetação e (D) Risco de acidente.

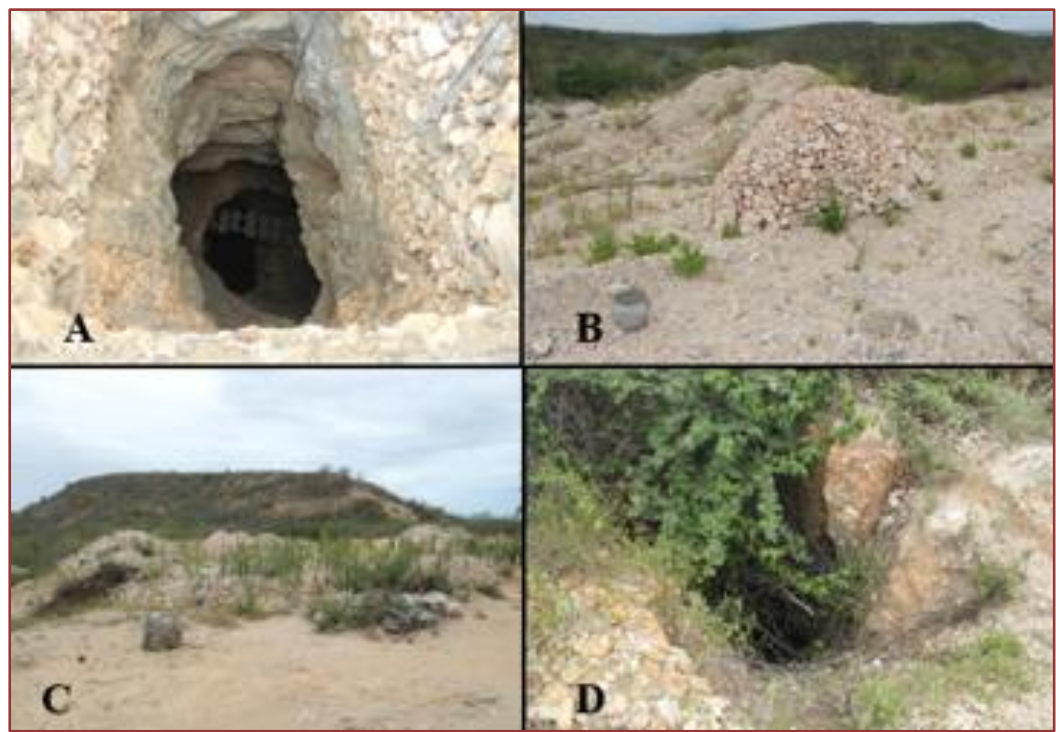

Fonte: Dados da pesquisa 
Garimpo Lagoa do André 1, encontrava-se inativo. A lavra é subterrânea, com extração de feldspato. Com relação aos impactos ambientais vistos na data da visita, foram; supressão da vegetação, alteração na topografia, deposição desordenada de estéril, risco eminente de desmoronamento como pode ser visto na Figura 6. Dentre os impactos vistos no local o risco de acidentes foi algo que chamou atenção nos acessos para exploração que é feita de forma rustica.

Figura 6: Impactos ambientais identificados no garimpo Lagoa do André 1. (A) Deposição aleatória de estéril; (B) Risco de acidente; (C) Acesso para extração mineral com alto risco de desmoronamento; (D) Pilhas de estéril

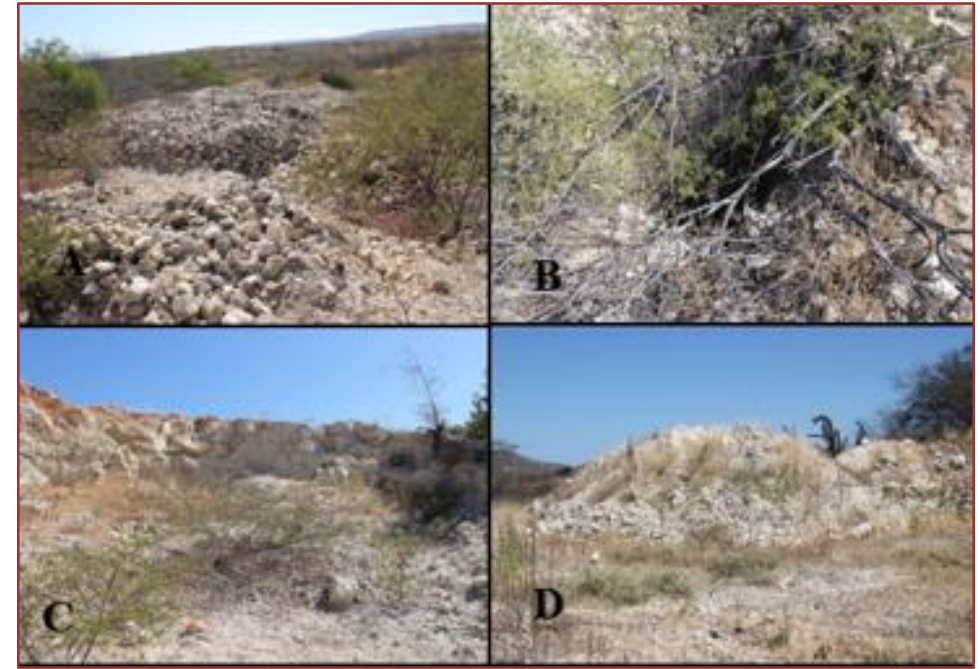

Fonte: Dados da pesquisa

O garimpo Lagoa do André 2 encontrava-se inativo no dia da visita. Sabe-se que a extração era feita através da lavra e a céu aberto e a substância mineral explorada era o feldspato. Foi identificado diversos impactos ao meio ambiente dentre eles: supressão da vegetação, alteração drástica da topografia, deposição desordenada de estéril, processos erosivos, risco de desmoronamento e deslocamento de fauna. Os processos erosivos estão em estado avançado, o risco de acidentes eminente, pois, não havia nenhuma sinalização que indicasse declives e os taludes são irregulares. Todos esses impactos podem ser melhores compreendidos observando a Figura 7.

Figura 7: Impactos ambientais identificados no garimpo Lagoa do André 2. (A) Risco de desmoronamento dos taludes; (B) Lixo depositado aleatoriamente; (C) Pilhas de estéril e (D) Processos erosivos.

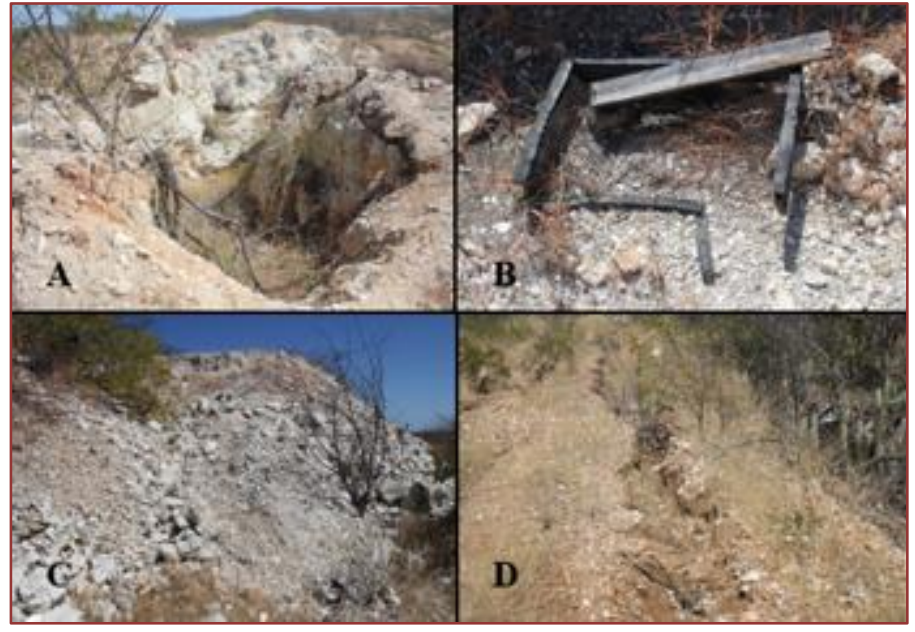

Fonte: Dados da pesquisa 
O garimpo denominado de Alto do Urubu localiza-se bem próximo da zona urbana, encontra-se inativo. A lavra também é a céu aberto e a extração também de feldspato. Como nos garimpos anteriores esse apresentou supressão da vegetação, alteração da topografia, deposição desordenada de estéril, sucatas dispersas, acumulo de lixo, diversos processos erosivos, risco de desmoronamento, assoreamento de riacho e contaminação de águas (Figura 8).

Por estar em situação de abandono, o acúmulo de lixo no local é preocupante, o assoreamento parcial de um riacho que conduz água ao principal açude da cidade, Várzea Grande, no município e que fornece agua para algumas cidades da região, o alto risco de acidentes, pois, no local não existe nenhum tipo de sinalização que indique fossos, locais com risco de desmoronamento, entre outros.

A implantação de medidas para atenuar esses impactos é de extrema importância para minimizar os impactos ambientais decorrentes da extração mineral o que propiciará aspectos positivos na atividade atual bem como maximizará os benefícios relacionados aos impactos que não podem ser mitigados.

Tendo como objetivo manter o meio ambiente que sofre influência direta bem como seu entorno, o mais próximo possível das condições ambientais atuais, buscando também compensar ou atenuar os efeitos degradativos existentes, buscando sempre uma condição menos impactante possível o que é o caminho da sustentabilidade (VASCONCELOS et al., 2009).

Figura 8: Impactos ambientais identificados no garimpo Alto do Urubu. (A) Deposição de lixo a céu aberto;

(B) Risco de desmoronamento; (C) Alteração da paisagem e (D) Deposição aleatória de estéril.

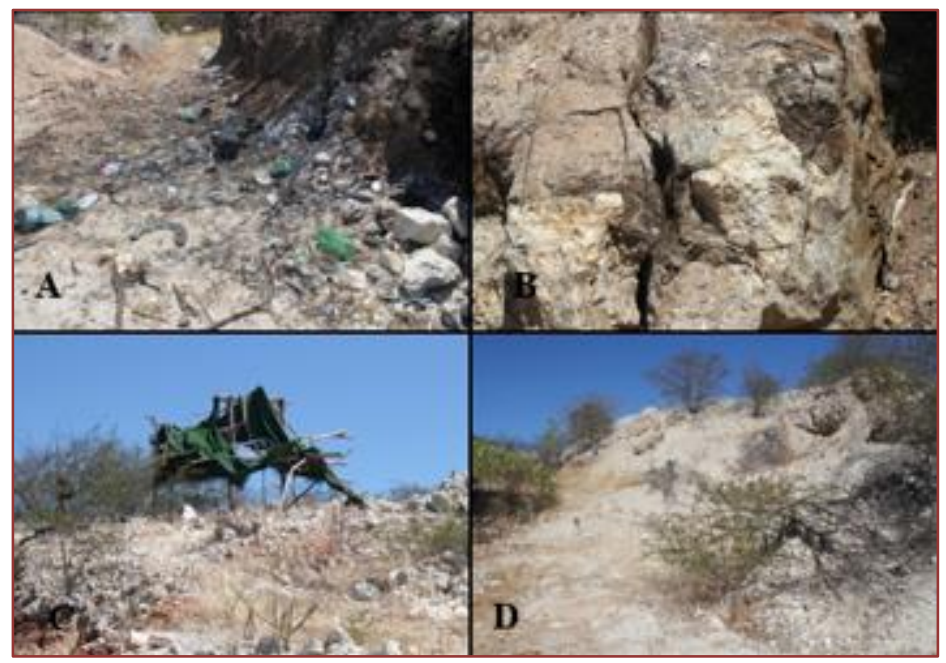

Fonte: Dados da pesquisa

É importante mencionar que a atividade mineradora é, de toda forma, vital para o desenvolvimento das sociedades. Mas isso não significa, no entanto, que ela deva ser realizada de maneira não planejada e sem a devida fiscalização de suas instalações.

\section{CONCLUSÕES E RECOMENDAÇÕES}

Ficou claro que na área pesquisada há um numero considerável de impactos ambientais causados pela atividade de extração mineral. No período da pesquisa, a maioria dos garimpos visitados encontraram-se inativos, isso seu deu devido ao fato de uma maior fiscalização com relação ao uso de explosivos, dificultando o trabalho dos garimpeiros.

A metodologia utlizada para avaliação dos impactos ambietais foi considera satisfatoria, pois, é de facil apliacação e entediento, o que facilitou a analise dos dados.

Os Principais Impactos detectados foram: assoreamento de riacho, contaminação do solo, deposição de lixo e estéril aletoriamente, supressão da vegetação, perigo de desmoronamento, alteração da topografia e erosão. 
Há necessidade da aplicação de medidas para atenuar esses danos ambientais, como também é muito importante a conscientização desses trabalhadores com relação ao tema.

É necessário um programa eficiente de disposição de resíduos gerados por parte da mineração, pois de uma forma geral, precisa-se fazer uso dos bens minerais no momento, porém, é preciso proporcionar um meio ambiente adequado para as futuras gerações, lembrando sempre que esses recursos não são renováveis.

Ao termino da pesquisa recomenda-se algumas que poderiam diminuir tais problemas, como: os garimpeiros procurar ógãos publicos para orientações com pesquisadores e grupos de estudo, como por exemplo o IFPB no qual existem trabalhos e pesquisas que facilitam e fornecem mais informações para melhor desenvolver o trabalho nos garimpos sem tanta geração de impactos ambientais, procurar órgãos como a prefeitura municipal para mais informações, cursos, palestras e informações favoravéis ao ambiente, bem como orgãos ambientais e orgão ligados a mineração.

\section{REFERÊNCIAS}

[1] Bacci, D.L.C.; Landim, P.M.B.; Eston, S.M. Aspectos e impactos ambientais de pedreira em área urbana. Ouro Preto, vol. 59 no 1, jan. mar. 2006. Disponível em: <http://www.scielo.br/scielo.php?pid=S0370$44672006000100007 \&$ script=sci_arttext > Acesso em: 09 de ago. 2017.

[2] Barbieri, J. C. Gestão Ambiental Empresarial: conceitos, modelos e instrumentos. São Paulo: Saraiva, 2004.

[3] Bitar, O. Y. Avaliação da recuperação de áreas degradadas por mineração na região metropolitana de São Paulo. Tese de Doutorado em Engenharia Mineral. Escola Politécnica da Universidade de São Paulo. São Paulo, 184 pg. 1997.

[4] Cprm. Diagnóstico do município de Picuí. Projeto Cadastro de Fontes de Abastecimento por Água Subterrânea, estado da Paraíba, 2005.

[5] Francisco, P. R. M.; Pereira, F. C.; Medeiros, R. M. de; Sá, T. F. F. de. Zoneamento de risco climático e aptidão de cultivo para o município de Picuí - PB. Revista Brasileira de Geografia Física, n. 4, v. 5, 1043-1055 p. 2011.

[6] Ibama - Instituto Brasileiro do Meio Ambiente e dos Recursos Naturais Renováveis. Avaliação de impacto ambiental: agentes sociais, procedimentos e ferramentas. Brasília, 136 p. 1995.

[7] Instituto Brasileiro de Geografia e Estatística (IBGE), Picuí. Disponível em: < http://cidades.ibge.gov.br >. Acesso em jan. 2018.

[8] Krüger, P. V. Estudo 57: Mineração. PIS - Perspectiva de Investimentos Sociais no Brasil. UFMG, Minas Gerais, 1880 p. 2009.

[9] Lima, H. C. A Trajetória do Setor Mineral no Município de Pedra Lavrada - PB: Uma Análise das Ações Públicas para Pensar o Desenvolvimento. Dissertação de Mestrado, UEPB, Campina Grande, 2013.

[10] Mechi, A. Analise Comparativa da Gestão Ambiental de cinco Pedreiras: Proposta de um Sistema de Gestão Ambiental. Campinas: Instituto de Geociências, Universidade Estadual de Campinas, 1999.

[11] Oliveira JR. J.B. e Coelho, M. O. Mineração S.A. - Plano de Recuperação de áreas degradadas: Espaço Alfa. 1994. 42 Paraná Mineral - programa de desenvolvimento da indústria mineral paranaense - perfil da indústria de agregados, 1999.

[12] Sánchez, L. E. Avaliação de impactos ambientais: conceitos e métodos. São Paulo: Oficina de Textos, 495 p. 2006.

[13] Santos, E.J.; Ferreira, C.A. e Silva JR., J.M.F. Geologia e recursos minerais do Estado da Paraíba: Texto explicativo dos mapas geológicos e de recursos minerais do Estado da Paraíba. Recife, Serviço Geológicos do Brasil/Departamento Nacional de Produção Mineral, 142 p. 2002.

[14] Tommasi, L.R. Estudo de impacto ambiental. São Paulo: CETESB: Terragraph Artes e Informática, 354 p. 1993.

[15] Vasconcelos, R. F. et al. Propostas de medidas mitigatórias em áreas de mineração em município do estado da Paraíba. XXIX ENCONTRO NACIONAL DE ENGENHARIA DE PRODUÇÃO, Salvador -BA, 2009.

[16] Zeferino, M. C. Legislação e Licenciamento: Medidas Mitigadoras e Compensatórias de Impactos Ambientais. Blog Mata Nativa, < http://www.matanativa.com.br/blog/medidas-mitigadoras-e-compensatorias-de-impactosambientais/> Acesso: abr. 2018. 


\section{Capítulo 3}

Cultivo e extrativismo da mangaba no Vale do Sambito: Uma estratégia economica para o municipio de Inhuma-Pi.

Francisco José dos Santos

Neydiane Pereira Lopes

Olimpio José dos Santos

Claudimeire Lima de Sousa

Resumo: As transformações no semiárido brasileiro tem se intensificado nas últimas décadas e as mudanças ocorridas fazem emergir novas posturas profissionais da população. 0 extrativismo é, portanto um método muito importante de convivência com as características peculiar dessa região, sendo o extrativismo da mangaba um bom exemplo disso. 0 cenário de estudo escolhido foi uma pequena comunidade da cidade de Inhuma-PI, Povoado Mangabas. A presente pesquisa tem como principal finalidade demonstrar a população da região, explorar o cultivo e extrativismo da mangaba, de forma que venha gerar uma renda sem agredir o meio ambiente. Foi desenvolvida a partir de um estudo de caso e bibliográfico, visitas "in loco", fotografias, realização de palestras, e questionário estruturado, onde se obteve os resultados sobre os benefícios da fruta, pois em alguns estados do Nordeste Brasileiro a atividade de cultivo e extração da mangaba é bem presente, e tem contribuído positivamente para as condições de vida dos indivíduos desta região. Foi constatado que na região há ocorrência de mangaba, mas que por falta de conhecimento dos benefícios nutritivos e econômicos a população não se beneficia como deveria, fazendo-se necessário ter incentivo e informação para desenvolver um manejo sustentável, gerando renda para a comunidade. No desenvolvimento da pesquisa foram mostrados para a comunidade os benefícios da mangaba, alguns benefícios que esse vegetal pode trazer para a região de Inhuma- PI, por isso cultivar e extrair a mangabeira pode ser uma alternativa sustentável para as famílias desta região e ao mesmo tempo uma estratégia socioambiental.

Palavras-chave: Transformação do semiárido, Extração, Cultivo da mangaba, Sustentabilidade. 


\section{INTRODUÇÃO}

As Mangabas é uma pequena comunidade da cidade de Inhuma-PI, precisamente localizada no Vale do Sambito, na região do Nordeste Brasileiro (NB), situado no "Polígono das Secas" parte do semiárido, que abrange ecossistemas frágeis e de baixa renda, devido às condições climáticas. 0 nome dessa pequena comunidade "Mangabas" surgiu devido existir a ocorrência com abundância do fruto Mangaba na região.

Sabe-se que o NB passa por dificuldades, pois se trata de uma região onde os recursos hídricos são escassos; problema causado por má distribuição de chuvas. 0 cultivo e extrativismo de vegetais tem sido uma estratégia socioambiental de sobrevivência e essa ideia tem mudado a realidade de muitas comunidades na região do NB, mais infelizmente por falta de conhecimento ainda existe regiões que não tem procurado essa estratégia tão importante, como é o caso da região de Inhuma-PI.

A mangaba (Hancornia speciosa Gomes) é um fruto bastante apreciado pelas excelentes características físicas, aroma e sabor, associado ao elevado valor nutritivo. Os frutos possuem aparentemente grande potencial de mercado, uma vez que a oferta não atende a demanda. Possuem polpa amarela adocicada, que é consumida in natura, como também utilizada para industrialização sob a forma de doces, geléias, compotas, vinho, vinagre, suco e sorvete (PERFEITO, 2014).

A mangabeira em algumas regiões possui mais de um nome popular, dependendo da região, diante deste fato para que os pesquisadores se comuniquem e tenham convicção que estão se referindo a mesma espécie, e de suma importância que a mesma possua um nome cientifico onde há ocorrência deste vegetal para que assim venha facilitar o manejo com esta planta. 0 nome cientifico da mangabeira é Hancornia Speciosa Gomes. (LIMA; SCARIOT, 2010).

O cultivo e a extração desse vegetal pode ser útil para diversos fins, até mesmo na medicina, considera-se que a mesma pode contribui tanto no desenvolvimento econômico como ambiental, podendo trazer uma vida melhor para os habitantes do vale do sambito.

A presente pesquisa foi desenvolvida a partir de um estudo de caso na região do Vale do Sambito precisamente no povoado Mangabas município da cidade de Inhuma-PI. Inicialmente foi realizada a coleta de dados bibliográficos onde analisou-se de livros, artigos e teses científicas na internet, precisamente no "google acadêmico" e em seguida realizada pesquisa de campo com fotografias, observação do local, e uma palestra de incentivo na I Feira de Articulação "O Despertar para Empreender", onde se encontrava todas as autoridades e comunidade em geral e em seguida foi executado um questionários semiestruturados (anexo1) onde 50 pessoas foram interrogadas na região de Inhuma-PI.

A principal finalidade deste trabalho é de demonstrar a comunidade da região, explorar o cultivo e extrativismo da mangaba, de forma que geri uma renda sem agredir o meio ambiente, mostrando para eles a importância dessa atividade e com tudo maximizar a conservação dos recursos genéticos do vegetal na comunidade e minimizar a escassez da espécie contribuindo positivamente para a sustentabilidade econômica e ambiental.

\section{SEMIÁRIDO BRASILEIRO}

O Semiárido brasileiro (SB) ocupa uma área de $969.589 \mathrm{~km}$ e inclui os Estados do Ceará, Rio Grande do Norte, a maior parte da Paraíba e Pernambuco, Sudeste do Piauí, Oeste de Alagoas e Sergipe, região central da Bahia e uma faixa que se estende em Minas Gerais, seguindo o Rio São Francisco, juntamente com um enclave no vale seco da região média do rio Jequitinhonha (CORREIA et al., 2010), Conforme a figura 1. 
Figura 1. Delimitação do Semiárido Brasileiro.

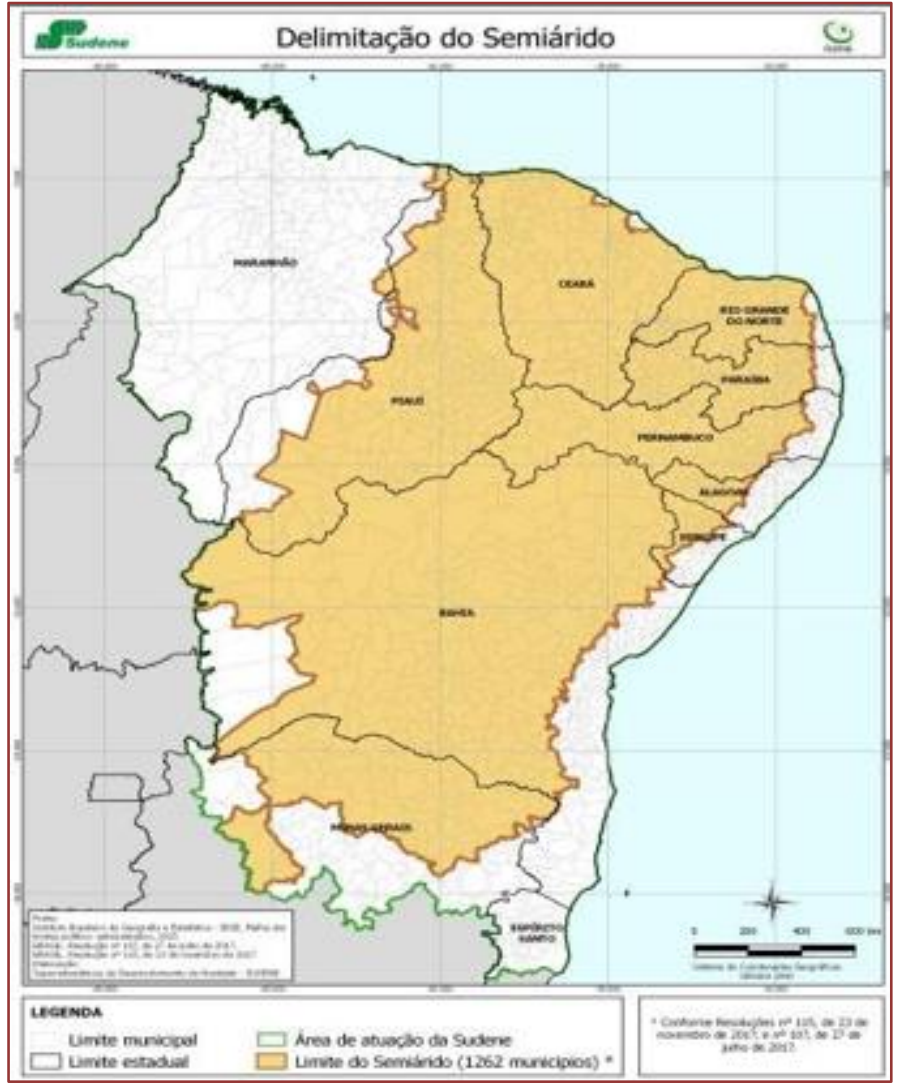

Fonte: IBGE, 2015

Uma das propriedades marcantes das perspectivas do Semiárido brasileiro é a vegetação de caatinga, com grande biodiversidade, no qual se destaca a formação vegetal xerófila (cactáceas, espécies arbóreas, herbáceas e arbustivas). A escassez de conhecimento, ainda, sobre o SB é a ocupação desordenada desse espaço levou à introdução de diversas atividades produtivas que não respeitaram as características da região, a sua vulnerabilidade climática, as particularidades dos solos dos recursos hídricos. A ocupação da área vem tornando os ecossistemas mais frágeis, proporcionando sérios riscos à sobrevivência humana com o uso intempestivo dos recursos naturais (SILVA et all 2010).

A insuficiência de chuvas, as temperaturas elevadas e as altas taxas de evaporação influenciam fortemente as demais condições naturais e sociais desse meio. Essas características influem diretamente nos recursos hídricos, nos solos, na paisagem e na vegetação, predominantemente constituída pelo bioma caatinga, e a multiplicidade de espécies que compõem essa biodiversidade. Agregam-se a esses fatores a histórica concentração da terra e da água, que favoreceu a dominação política, baseada no autoritarismo, no paternalismo e no clientelismo (CONTI; SCHROEDER, 2013).

\section{SEMIÁRIDO PIAUIENSE}

De acordo com a região Piauiense com base nos fins do Planejamento Participativo Territorial para o Desenvolvimento Sustentável do Estado, a Macrorregião do Semiárido piauiense foi dividida em quatro Territórios de Desenvolvimento: Vale do Rio Guaribas, Vale do Rio Canindé, Vale do Rio Sambito e Serra da Capivara (SILVA et all 2010).

A região do semiárido piauiense está ocupada com os principais rios: Canindé, Itaim, Guaribas e Riachão, todos temporários; a água nos seus leitos só permanece durante o período chuvoso. A utilização desses rios para o cenário socioeconômico ainda deixa muito a desejar, pois o mesmo poderia ser aproveitado por meio da cultura de vazantes, irrigação para culturas como feijão, milho, algumas hortaliças e alho, e assim beneficiar toda a comunidade já está em decadência há alguns anos. Na realidade, existe um sub aproveitamento dos recursos hídricos da região, tanto dos rios como das barragens e da água subterrânea mais ainda está muito disperso. (SILVA et all 2010). 
Território Vale do Sambito ocupa cerca de 19\% da área da Macrorregião de Desenvolvimento do Semiárido na sua porção norte, com 1.374.115 hectares. Conforme segue a figura 2.

Figura 2. Mapa Territorial do vale do sambito.
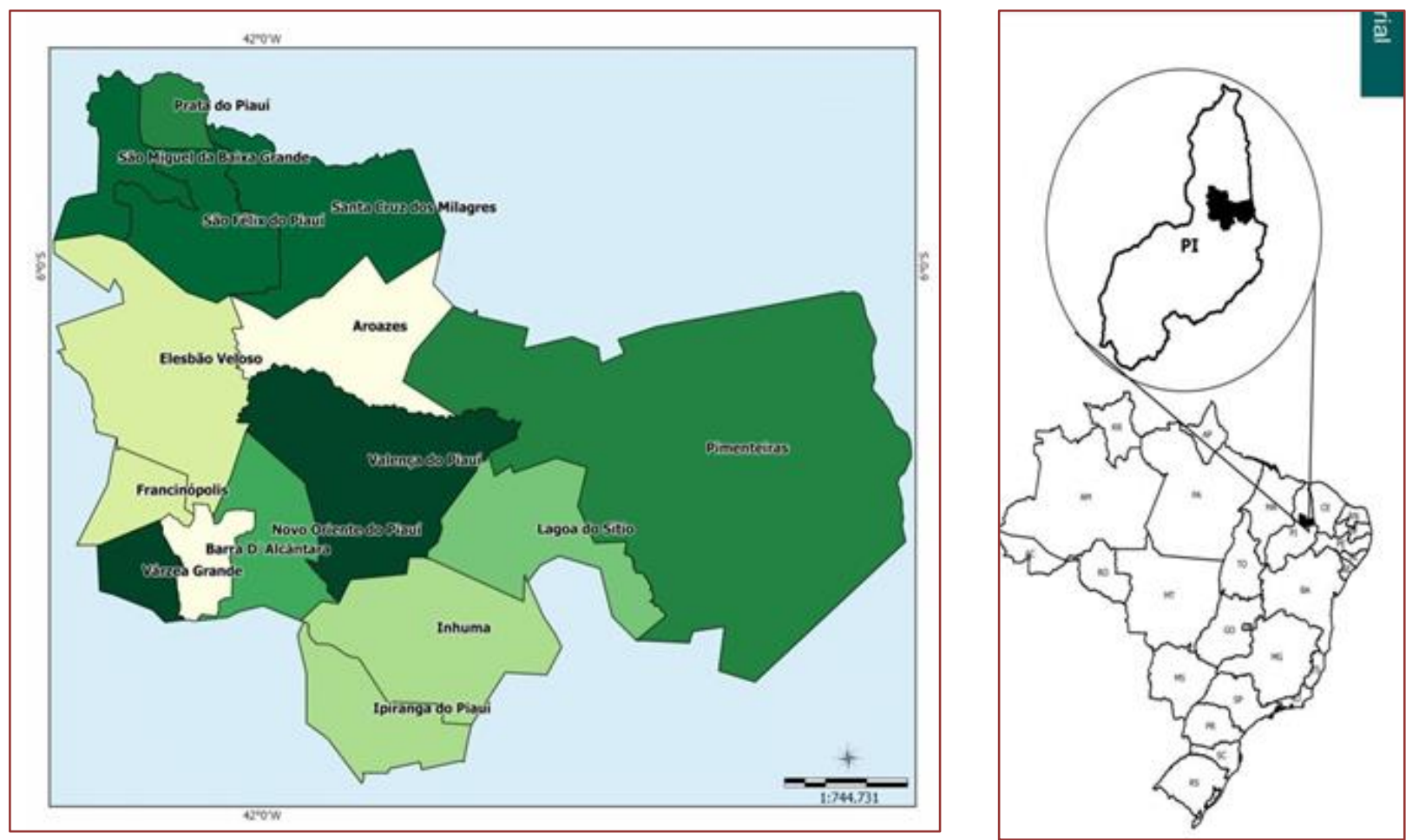

A atividade de agropecuária na região do vale do sambito supera a vegetação da caatinga e o que mais se destaca é uma grande área empresarial de caju na área do município de Pimenteiras. 0 quadro 01 apresenta as principais culturas da macrorregião do semiárido vale do sambito. A pecuária bovina é destaque em Pimenteiras e em Elesbão Veloso; suínos em Inhumas; e caprinos em Valença do Piauí e Pimenteiras (CODEVASF/PLANAP, 2006, vol. 13).

Quadro 01. Principais culturas da Macrorregião do Semiárido Vale Do Sambito.

\begin{tabular}{|c|c|c|c|c|c|}
$\begin{array}{c}\text { MUNICÍPIO DO VALE DO } \\
\text { SAMBITO. }\end{array}$ & $\begin{array}{c}\text { ARROZ } \\
\text { EM CASCA }\end{array}$ & $\begin{array}{c}\text { CASTANHA DE } \\
\text { CAJU }\end{array}$ & \multicolumn{2}{|c|}{ FEIJOÃO } & \multicolumn{2}{c|}{ MANDIOCA } & MILHO \\
\hline Pimenteiras & $\mathrm{X}$ & $\mathrm{X}$ & $\mathrm{X}$ & $\mathrm{X}$ & \\
\hline Valença do Piauí & $\mathrm{X}$ & & & $\mathrm{X}$ & \\
\hline Elesbão Veloso & $\mathrm{X}$ & & & & \\
\hline Inhumas & & $\mathrm{X}$ & $\mathrm{X}$ & $\mathrm{X}$ & \\
\hline Aroazes & & & $\mathrm{X}$ & & \\
\hline Ipiranga do Piauí & & & & $\mathrm{X}$ & \\
\hline Lagoa do Sítio & $\mathrm{X}$ & & & & $\mathrm{X}$ \\
\hline
\end{tabular}

Fonte: codevasf/planap, 2006, vol. 13. 
O território da cidade de Inhuma-Pi ocupa área de 1.042,8 $\mathrm{Km}^{2}$ da Macrorregião do Semiárido Piauiense, sua vegetação está caracterizada como Cerrado, o solo está caracterizado como Latossolo e Neossolo, 0 clima é predominantemente semiárido quente, segundo a classificação de Koeppen, com 6 a 8 meses secos no ano, Temperatura média anual de cerca de $24{ }^{\circ} \mathrm{C}$ e máxima anual de $33{ }^{\circ} \mathrm{C}$ (CODEVASF/PLANAP, 2006,

vol. 13.).

Figura 3. Localização geográfica da região de Inhuma-PI.

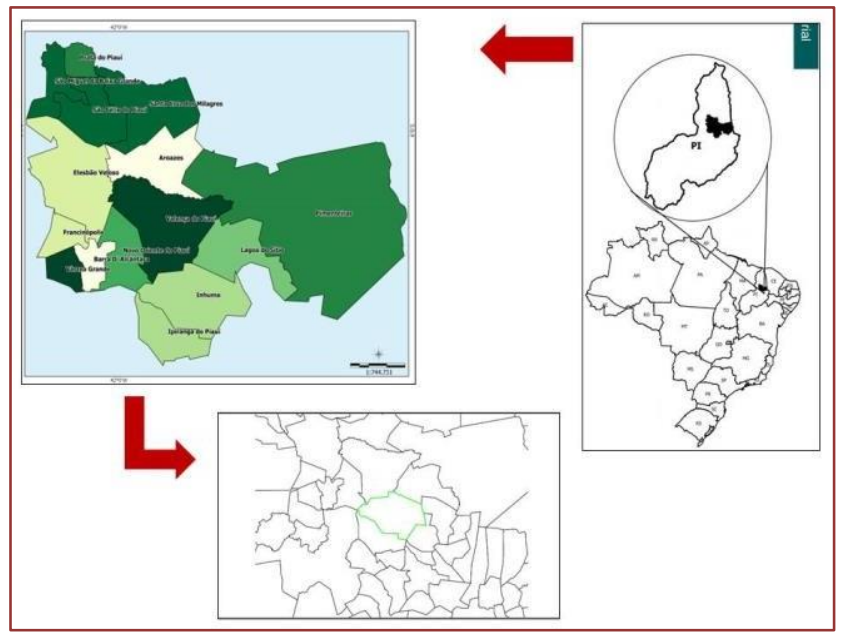

Fonte: Dados da pesquisa

\section{CULTIVO, EXTRATIVISMO DA MANGABA E 0 MEIO AMBIENTE.}

A atividade de extração e do cultivo no semiárido é bem presente e tem um enorme potencial. As principais culturas são manejo com: sementes, flores, frutas, folhas, raízes, cascas, látex, óleos, resinas e madeiras que possuem inúmeras utilidades como alimentos, medicamentos, utensílios, ferramentas e artesanatos. Muitas dessas atividades trazem diversos benefícios tanto para a utilização domestica quanto para a comercialização e assim proporcionar renda para as famílias (LIMA e SCARIOT, 2010).

Tomazi, R, (2016), destaca que a exploração do vegetal mangaba é feita de duas formas:

1) extrativismo, em pomares nativos, usando mão-de-obra desqualificada, caracterizando a sua importância socioeconômica para as populações da zona rural, que a tem como fonte de renda, sem nenhum investimento prévio, considerando-se que se encontra em estado silvestre;

2) pomares cultivados tecnicamente. Por ser uma cultura que está despontando no negócio da fruticultura pelas suas aplicações, tem gerado uma expectativa de crescente demanda.

A cultura de cultivo da Mangabeira é bem simples, no entanto bem acessível, pois a semente de mangaba demora de 15 a 40 dias para germinar, sendo que de cada 100 sementes, 80 a 90 vão germinar, destas de 15 a 20 mudas provavelmente irão morrer depois de plantadas (LIMA e SCARIOT, 2010).

0 fruto da mangabeira (Hancornia speciosa Gomes), mangaba é um produto extrativo de grande relevância para o país, constando nos relatórios anuais do Panorama do Extrativismo Vegetal e da Silvicultura (PEVS), publicação anual do Instituto Brasileiro de Geografia e Estatística (IBGE). A árvore ocorre nas cinco regiões do Brasil, Precisamente na região nordeste nos estados do Sergipe, Paraíba, Pernambuco, Ceará, Piauí, Maranhão e parte do estado da Bahia - excetuando-se os estados de Santa Catarina e Rio Grande do Sul (na região Sul do país), bem como Acre e Roraima (na região Norte do país) apresentando-se em seis variedades botânicas aceitas, que se diferenciam principalmente por diferenças morfológicas das flores, folhas (OLIVEIRA, et all 2017).

O trabalho das mulheres (catadoras) se resume em derrubar o fruto "de vez", com auxílio de um gancho de arame, acoplado ou não a uma vara e colher os frutos que caem. Após a catação, os frutos são colocados em baldes e transportados para as residências. Embora aqueles frutos colhidos, ao caírem no chão, naturalmente, sejam reconhecidos como mais saborosos, são sensíveis ao manuseio e transporte e assim 
promove algumas alterações negativas a fruta proporcionando um consumo não exitoso pela a clientela (GONÇALVES, G. A. S. 2017).

O extrativismo da mangada traz benefícios para milhares de famílias e mesmo contribuindo para conservação da biodiversidade, enfrenta muitos desafios, sendo um deles a logística, desde o momento em que o delicado fruto cai até sua comercialização desorganizada por estes motivos as famílias que trabalham com esta atividade acham o valor econômico do fruto baixo (LIMA e SCARIOT, 2010).

OLIVEIRA, et all (2017) destaca que apesar da importância socioeconômica da espécie para Sergipe e a Paraíba, as áreas onde há ocorrência natural das mangabeiras estão sofrendo intensa pressão por parte do cultivo de monoculturas (como cana-de-açúcar, coqueiro e eucalipto), expansão imobiliária, avanço turístico e implantação ilegal de viveiros de camarão o que diminui as áreas disponíveis para extrativismo o que proporciona sérios problemas.

\section{IMPORTÂNCIA SOCIOAMBIENTAL E ECONÔMICA DA MANGABA}

No mercado o vegetal mangaba são muito bem requisitados tanto para serem consumidos processados ou puros da forma in natura. 0 processamento industrial do vegetal resulta em vários produtos, como polpas, geleias, sorvetes, sucos, doces, bolos, biscoitos e licores. Na Região Nordeste, uma das frutas mais requisitadas na indústria de frutas nativas da região é a mangaba, na fabricação, polpas congeladas e sorvetes (LIMA; SCARIOT, 2010).

Na concepção de Tomazi, R, (2016) a mangaba é um fruto de alto valor nutricional, rico em provitamina A, vitaminas B1, B2 e C, além de ferro, fósforo e zinco. Havendo a presença de taninos, compostos fenólicos e pigmentos naturais, elevando o potencial para industrialização, conferindo desta forma à mangabeira um sabor exótico e aroma peculiar Seus frutos são aromáticos, saborosos e nutritivos, com ampla aceitação de mercado, tanto para o consumo in natura quanto para a agroindústria.

Além dos frutos, outras partes da planta são utilizadas na medicina popular, sendo a casca utilizada contra dermatoses e como estimulante de funções hepáticas e o látex para combater a tuberculose e o tratamento de úlceras. A madeira é usada como lenha. Seu látex, conhecido como "leite de mangaba" foi muito usado no início do século XX como substituto da borracha (Hevea brasiliense), embora de qualidade um pouco inferior (LIMA, 2008).

De acordo com Santos, E. A; Souza, R. M (2016) dos frutos comercializados em Sergipe, 90\% provém de áreas nativas nas quais populações tradicionais desenvolvem o extrativismo há séculos. No estado cerca de 2500 famílias correspondendo a 7500 pessoas sobrevivem da extração de recursos naturais locais. 0 extrativismo da mangaba tem uma importância social e econômica para essas populações, uma vez que é relevante para a segurança alimentar desse grupo e responsável por $60 \%$ dos seus rendimentos anuais.

Apesar da sua importância socioeconômica e de ser reconhecida como árvore símbolo do Estado pelo decreto no 12.723/ 1992 a mangabeira não tem proteção legal que proíba o corte e que possibilite o livre acesso das extrativistas nas áreas de ocorrência, gerando mais problemas para a comunidade extrativista da região.

Nas conjecturas de Lima; Scariot (2010) destacou que em alguns estados do nordeste há varias instruções de manejo com a mangabeira que contribui para o extrativista coletar o fruto da melhor maneira possível, sem que danifique a planta e o fruto, contribuindo para a preservação da mesma, Visto que essas recomendações trazem vários benéficos, um deles e o índice de qualidade da fruta o que facilita comercializa-la da melhor forma possível (LIMA, SCARIOT, 2010).

A mangabeira pode ser utilizada em varias finalidades como produto medicinal e na fabricação de doces, sorvetes e geleias, sendo uma das espécies nativas de importância para o fomento de uma economia baseada na utilização e conservação de recursos naturais das regiões em que se desenvolvem, todos esses subprodutos do fruto em estudo tem fundamentos no seu importante valor nutritivo e que devido ao sabor e aroma excelentes, há uma crescente demanda para consumo in natura e na agroindústria. 0 óleo das sementes ainda não tem seu estudo explorado e pode também ser uma alternativa de exploração sustentável (TOMAZI, R, 2016). 


\section{RESULTADOS E DISCUSÕES}

Os dados obtidos no questionário aplicados foram catalogados em gráficos que serão apresentados a seguir

Figura 4.

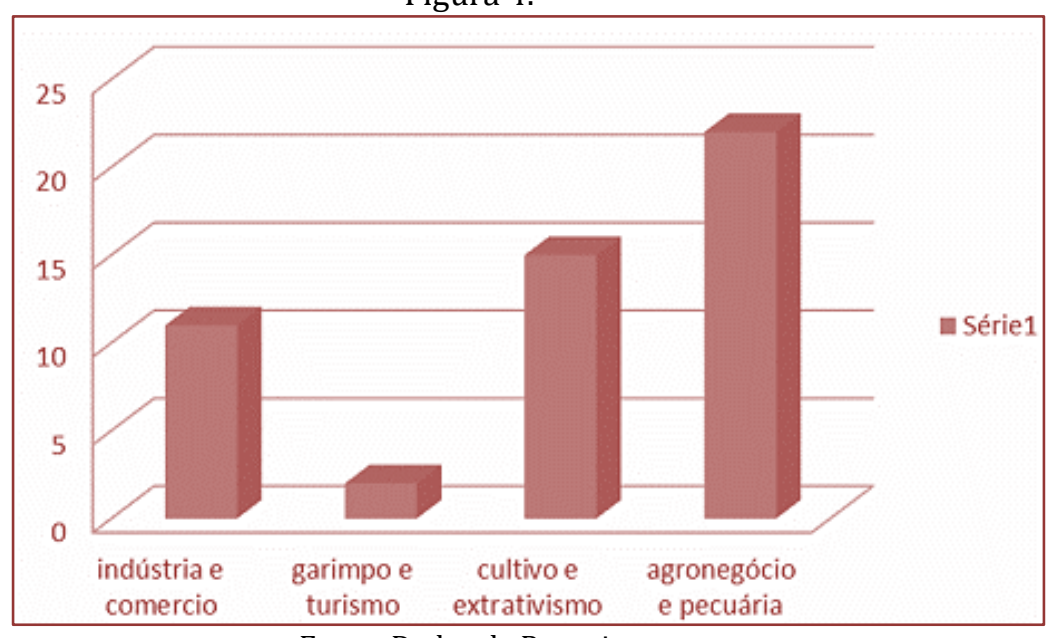

Fonte: Dados da Pesquisa

De acordo com os dados da figura 4, considerando qual seria a melhor estratégia de convivência com o semiárido Inhumense, das 50 pessoas entrevistadas 11 pessoas afirmaram que é atividade de indústria e comercio, 2 pessoas afirmam que é garimpo e turismo, 15 pessoas apostam na atividade de cultivo e extrativismo e 22 pessoas acreditam no agronegócio e pecuária, diante dos dados constatou-se que a atividade de agronegócio e comercio e vista pela a maioria dos entrevistados que é a melhor estratégia de convivência com o semiárido, o que leva a entender que eles não tem o conhecimento das potencialidades do cultivo e do extrativismo nessa região.

Figura 5.

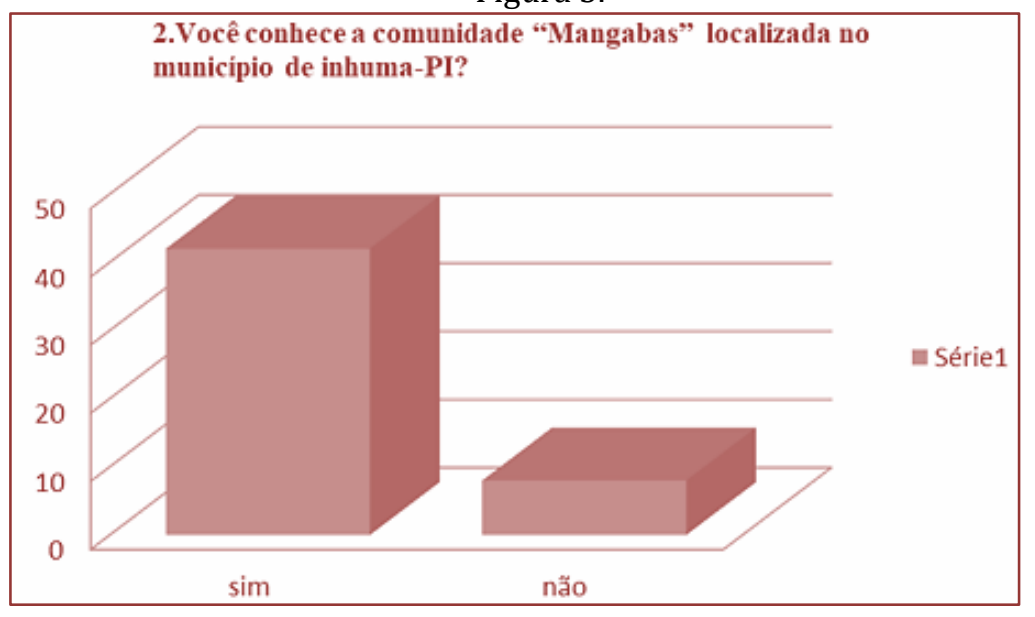

Fonte: Dados da Pesquisa

Observando os dados da figura 5, conclui-se que das 50 pessoas entrevistadas 42 pessoas conhecem a comunidade mangabas, restando apenas 8 pessoas que não conhecem a comunidade e foi questionado por que a comunidade recebeu esse nome? Das 50 pessoas entrevistadas 40 pessoas afirmaram que sim que foi por que havia ocorrência com abundancia do vegetal mangaba na região antes de sofrer a ação antrópica, 5 pessoas acha que é por que lá existe pessoas com esse sobrenome e as outras 5 pessoas afirmam que é por que existe uma lenda. 
Figura 6.

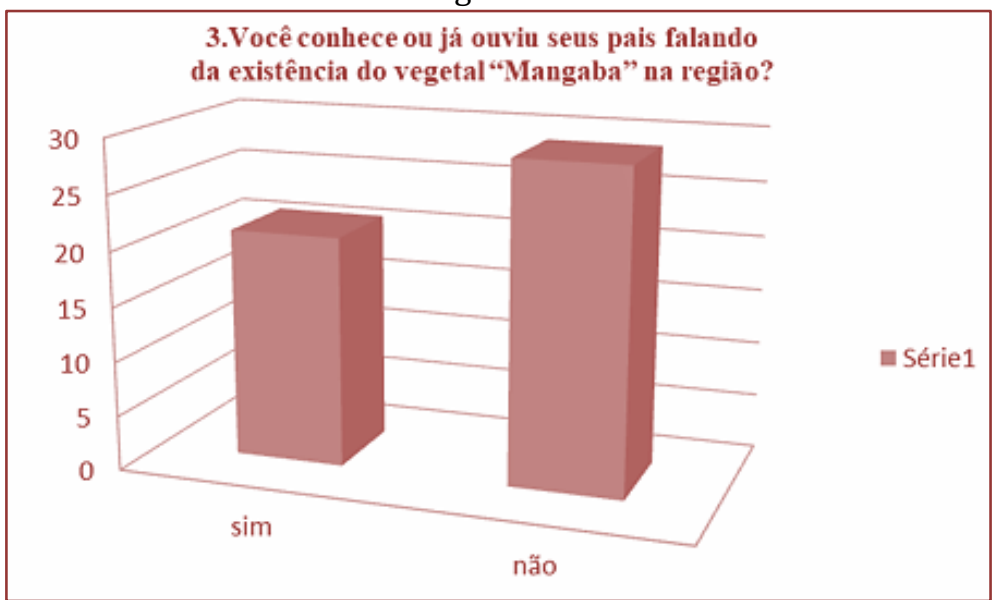

Fonte: Dados da Pesquisa

Analisando os dados da figura 6, estima-se que das 50 pessoas entrevistadas 21 pessoas relatam que não conhece e nunca viram seus pais falando da existência do vegetal mangaba e 29 pessoas das entrevistadas afirmam que conhece ou já viram os seus pais falando da existência da fruta, conclui que a maioria tem o conhecimento da existência da fruta e isso contribuir positivamente para a execução da atividade de cultivo e extrativismo na região.

Figura 7

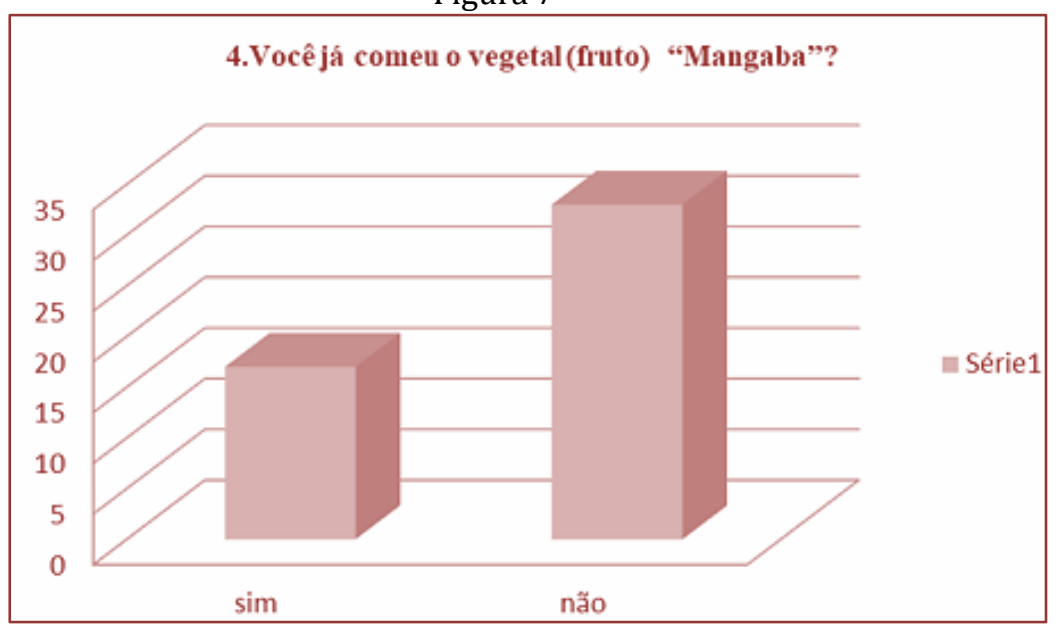

Fonte: Dados da Pesquisa

Conforme verificado na figura 7, no que se refere quem já comeu ingeriu o vegetal mangaba observa-se que apenas 17 pessoas das 50 entrevistadas degustaram do vegetal

mangaba e 33 pessoas dessas 50 nunca provaram a fruta, ou seja, não tiveram a oportunidade de comer, algumas até já ouviram falar da existência da fruta, conforme os dados destacados da figura 09, ou seja, não sabem que sabor tem o que desperta muita curiosidade. 
Figura 8.

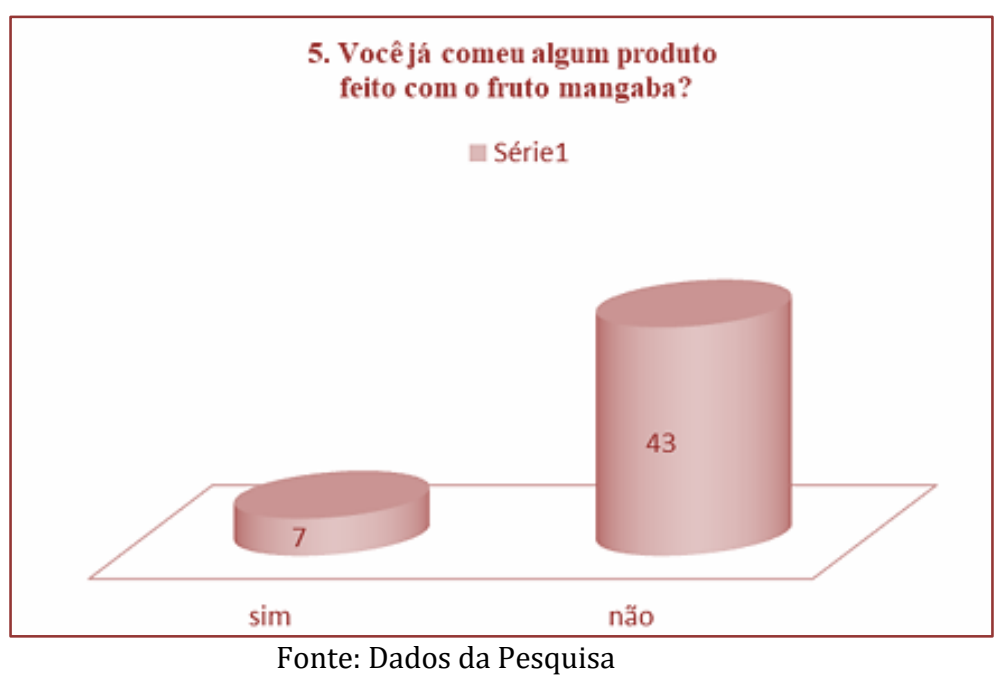

A figura 8, destaca que das 50 pessoas entrevistadas 7 pessoas comeram produtos processados da fruta mangaba e que 43 destas nunca provaram nada que pudesse ser derivados da mangaba. Configura que boa parte destes não conhece nem um terço do que se pode fazer com o processamento da fruta, o que pode trazer vários benefícios para todos da região ao aderi a atividade de cultivo e extrativismo do vegetal visto que o já existe ocorrência de mangabeira nessa região, por isso e importante conhecer os benefícios nutritivos e econômicos que a mangaba proporciona.

Figura 9.

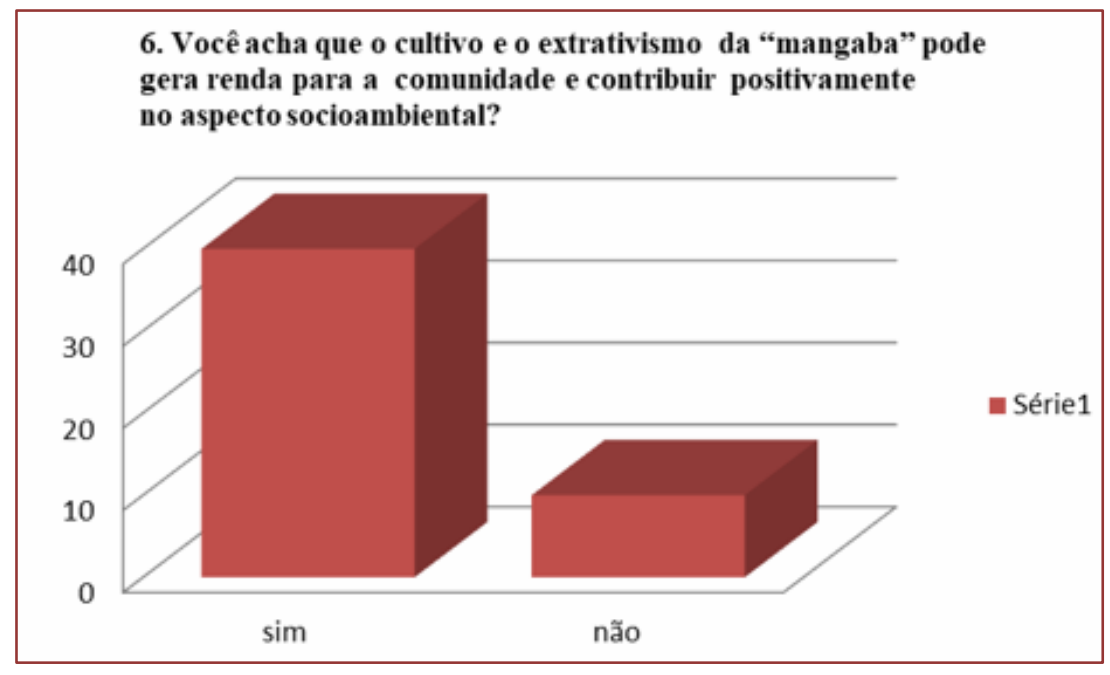

Fonte: Dados da Pesquisa

Considerando os dados da figura 9, observa-se que 40 pessoas das 50 entrevistados acredita que a atividade de cultivo e extrativismo do vegetal mangaba pode gerar renda para a comunidade e contribuir no aspecto socioambiental; e apenas 10 pessoas destas não acreditam nessa possibilidade, diante dos fatos pode-se analisar que a maioria dos entrevistados tem consciência dos impactos positivos que essa cultura pode proporcionar, isso no âmbito social, econômico, e ambiental.

Pois em alguns estados do Nordeste Brasileiro a atividade de cultivo e extração da mangaba é bem presente, e tem contribuído positivamente para as condições de vida dos indivíduos desta região. Por ser um vegetal adepto a clima seco o cultivo dela na região de Inhuma-PI pode contribuir positivamente no cenário socioeconômico e ambiental melhorando a realidade de vida de muitos que sofrem impactos causados pelas condições climáticas da região. 


\section{CONSIDERAÇõES FINAIS}

Foi constatado que na região há ocorrência de mangaba, mas que por falta de conhecimento dos benefícios nutritivos e econômicos a população não se beneficia como deveria, fazendo-se necessário ter incentivo e informação para desenvolver um manejo sustentável, gerando renda para a comunidade.

No desenvolvimento da pesquisa foram mostrados para a comunidade os benefícios da mangaba, pois os frutos da mangabeira são bem aceitos no mercado, tanto para serem consumidos puros quanto processados; o processamento da fruta resulta em vários produtos: geleias, sorvetes, sucos, doces, biscoitos e licores. Outras partes da planta também são utilizadas, a madeira é usada como lenha; a casca utilizada contra dermatoses e como estimulante de funções hepáticas; o látex é usado para combater a tuberculose; as folhas e raízes também são usadas na medicina popular. É um fruto de alto valor nutricional, rico em provitamina A, vitaminas B1, B2 e C, além de ferro, fósforo e zinco.

São muitos os benefícios que esse vegetal pode trazer para a região de Inhuma-PI, por isso cultivar e extrair a fruta mangaba pode ser uma alternativa sustentável para as famílias desta região e ao mesmo tempo uma estratégia socioambiental e de convivência com o semiárido. Diante de todas as conjecturas analisadas e demostradas, o setor publico municipal da cidade de inhuma abraçou a ideia e está sendo implantada uma associação de cultivo e extrativismo de mangaba no Pov. Mangabas e assim contribuir positivamente no aspecto econômico e ambiental da região.

\section{REFERÊNCIAS}

[1] Correia, R. C. et al. A região semiárida brasileira. Produção de Caprinos e Ovinos no Semiárido. Petrolina, 2010.

[2] Conti, I. L; Schroeder, E. O. Estratégias de convivência com o semiárido brasileiro.

[3] Textos e artigos de alunos(as) participantes. Brasília, 2013. CODEVASF/PLANAP - Síntese Executiva Uso da Terra, v. 13, 2006.

[4] Gonçalves, G. A. S. Estabilidade da Polpa de Mangaba (Hancornia Speciosa Gomes) Congelada d Armazenada. Tese (doutorado) - Universidade Federal de Lavras - Lavras-MG 2017.

[5] Instituto Brasileiro de Geografia e Estatística- IBGE, Malha dos limites politico- administrativo, 2015.

[6] Lima, I. L. P. Etnobotânica quantitativa de plantas do cerrado e extrativismo de mangaba (HancorniaSpeciosa Gomes) no norte de Minas Gerais: Implicações para o manejo sustentável. Dissertação de mestrado em ecologia. Brasília, 2008.

[7] Lima, I. L. P.; Scariot, A. Boas práticas de manejo para o extrativismo sustentável da Mangaba. Distrito Federal: Embrapa Recursos Genéticos e Biotecnologia, 2010. Disponível em: < http://docplayer.com.br/41912106boas-praticas-de-manejo-para-o-extrativismo- sustentavel-da-mangaba.html> acessado em: 06 nov. 2017.

[8] Mota, D.M.; Silva Júnior, J.F.; Schmitz, H. Os catadores de mangaba e a conservação da biodiversidade no território Sul sergipano. In: Congresso Brasileiro de Economia e Sociologia Rural . 43, Ribeirão Preto, 2005, Anais, Brasília: SOBER. Pesquisa financiada com recursos do MCT/CNPq. Disponível em: < http://docplayer.com.br/9553184- os-catadores-de-mangaba-e-a-conservacao-da-biodiversidade-no-territorio-sulsergipano- 1.html> acessado em: 02 Dez 2017.

[9] Oliveira, D. M; Cruz, D. S; Freitas, B. A.; Lima, L; T. N. M; GOMES, L. J; Identificação dos pontos críticos no sistema extrativista da mangaba (Hancornia speciosa Gomes) em Sergipe. Guaju, Matinhos, v.3, n.1, 2017.

[10] Perfeito, D. G. A. Processamento da polpa de mangaba (Hancorniaspeciosa Gomes). Tese de doutorado em tecnologia de alimentos. Campinas, 2014.

[11] Silva, C. M. S; Lima, E. S; Cantalice, M. L; Alencar, M. T.; Silva, W. A. L; Semiárido Piauiense: Educação e Contexto / (Orgs), INSA. Campina Grande: 2010. 236p ISBN: 978-85-61175-05-4. Disponível em: < https://pt.slideshare.net/mcti/semirido- piauiense-educao-e-contexto> acessado em: 01 jan. 2018.

[12] Santos, E. A; Souza, R. M; Territorialidade das Catadoras de Mangaba no litoral Sul de Sergipe. Geosaberes, Fortaleza, v. 6, número especial (3), 2016.

[13] Tomazi, R. A potencialidade da produção de mangabeiras (Hancorniaspeciosa Gomes) para o desenvolvimento do Amapá: caracterizações físicas, físico-químicas e químicas. Dissertação (Mestrado) - Fundação Universidade Federal do Amapá, Programa de Pós-Graduação em Desenvolvimento Regional. - Macapá, 2016. Disponível em: < http://www2.unifap.br/ppgmdr/files/2016/03/a-potencialidade-da-produ $\tilde{A} \ddagger \tilde{A} f o-d e-$ mangabeira.pdf> acessado em: 05 Fev. 2018. 


\section{ANEXO I}

\section{QUESTIONÁRIO}

1) Considerando que o município de Inhuma-PI fica localizado no semiárido brasileiro, e por tanto tem clima seco, com base nas potencialidades do município, em sua opinião qual seria a melhor estratégia para conviver com essa realidade?

2) Você conhece a comunidade "mangabas" localizada no município de Inhuma-PI?

3) Você conhece ou já ouviu seus pais falando da existência do vegetal "Mangaba” na região?

4) Você já comeu o vegetal (fruto) "Mangaba”?

5) Você já comeu algum produto feito com o fruto mangaba?

6) Você acha que o cultivo e o extrativismo da "mangaba" pode gera renda para a comunidade e contribuir positivamente no aspecto socioambiental? 


\section{Capítulo 4}

Veredas do semiárido cearense: 0 fomento ao geoturismo no parque estadual das Carnaúbas

\section{Hermógenes Henrique Oliveira Nascimento}

Resumo: Este trabalho objetiva analisar o potencial geoturístico do Parque Estadual das Carnaúbas, localizado no município de Granja, aproximadamente 365 km de Fortaleza, buscando contribuir com o registro, valorização e conservação da sua geodiversidade. Para tanto, a metodologia adotada se baseou no estudo por documentação indireta e direta, caracterizando-se de cunho qualitativo. Com a análise de campo foi possível apresentar um roteiro geoturístico composto de uma trilha para o Parque, abordando além de atrativos geológicos, toda a evolução histórico-cultural da região. Por fim, constatou-se que, se realizada de forma sustentável, a integração do geoturismo com as demais modalidades de turismo, conjuntamente com as atividades ambientais do Parque pode representar um grande desenvolvimento econômico regional.

Palavras-Chave: Geodiversidade; Parque Estadual das Carnaúbas; Geoturismo. 


\section{INTRODUÇÃO}

A atividade turística vem se transformando nas últimas décadas, resultante das mudanças de ordem econômica, ambiental, social e cultural. 0 surgimento de novos interesses e motivações contribui para o incremento de modalidades alternativas do turismo. Entre elas, encontra-se o geoturismo e dentre este, mais especificamente, o espeleoturismo. Esta categoria direciona a realização das atividades em ambientes cavernícolas, já o geoturismo tem uma relação muito próxima com a denominada geoconservação, contribuindo para o desenvolvimento de um turismo voltado para a preservação e conservação em sistemas cársticos.

0 conceito de geodiversidade é relativamente novo. Sua utilização se inicia a partir dos anos de 1990, consolidando-se ao longo dos últimos anos dessa década. Na literatura internacional, a geodiversidade tem sido aplicada com maior ênfase aos estudos de geoconservação. Nesse sentido, destacam-se os estudos destinados à preservação do patrimônio natural, tais como monumentos geológicos, paisagens naturais, sítios paleontológicos etc.

Já Eberhard (1997) introduz o conceito de geodiversidade com esse viés, definindo-o como "a diversidade natural entre aspectos geológicos, do relevo e dos solos". Cada cenário da diversidade natural (ou paisagem natural) estaria em constante dinâmica por meio da atuação de processos de natureza geológica, biológica, hidrológica e atmosférica. E Gray (2004) concebe uma definição bastante similar; todavia, estende sua aplicação aos estudos de planejamento territorial, ainda que com ênfase destinada à geoconservação.

As relações mais diretas entre o turismo e a paisagem cárstica se dão em função do meio físico. Todavia, elas não são as únicas existentes, pois isso seria uma perspectiva que reduz o turismo à simples interpretação, compreensão e uso dos aspectos geológicos, geomorfológicos, pedológicos e climáticos de um determinado lugar. Entende-se que as relações com o meio biótico e com as sociedades e culturas locais também influenciam e interferem no potencial e na qualidade dos produtos geoturísticos.

Neste pano de fundo, o presente trabalho vem mostrar que o Parque Estadual das Carnaúbas (PEC) engloba uma pequena fração do enclave úmido do Planalto da Ibiapaba no município de Viçosa do Ceará, incluindo uma parcela significativa da Serra de Ubatuba que é revestida por relíquias de cerrados, localizada em uma área que apresenta significativa variedade de sistemas ambientais e uma biodiversidade extremamente rica. A área também inclui superfícies pediplanadas sertanejas do município de Granja revestidos por caatingas, abrangendo planícies fluviais e áreas de inundações sazonais onde estão adensados os carnaubais que emprestam o nome a UC.

O PEC fica situado sobreposto na APA da Serra da Ibiapaba, apresenta-se, em boa porção, com um relevo ruiniforme elaborado sobre o arenito, um tipo de relevo onde a paisagem se parece com ruínas abandonadas, cuja gênese particular está intimamente associada à erosão pluvial que atuou sobre as variações faciológicas mais resistentes do arenito do Grupo Serra Grande, o que permitiu que essas formações ganhassem ressalto topográfico em relação ao entorno imediato, litologicamente mais tenro.

Mediante a realidade exposta, referente ao objeto de estudo, justifica-se essa pesquisa, na medida que é importante compreender a potencialidade existente na referida UC no que tange o seu acervo geológico, onde guarda jazidas paleontológicas e monumentos arqueológicos que remontam à época do homem préhistórico, pois, assim, o turismo em áreas protegidas abre perspectivas para a valorização e revitalização do patrimônio e da geodiversidade, do revigoramento das tradições e da história local, da redescoberta de bens culturais materiais e imateriais, muitas vezes reprimidas pela concepção consumista moderna.

Dessa forma, esse trabalho objetiva investigar se a implantação de políticas públicas a partir de uma trilha geoturística no Parque Estadual das Carnaúbas pode oferecer ao visitante um aprofundamento sobre as origens da história do ambiente com base em informações geológicas, ao mesmo tempo em que constitui igualmente um elemento essencial para incluir pessoas no contexto das discussões e reflexões, além de explorar toda a geodiversidade e paisagem cárstica local.

\section{METODOLOGIA}

A metodologia científica pode ser compreendida, de forma resumida, como a soma de técnicas e processos empregados na realização de uma pesquisa (MARCONI; LAKATOS, 2003). A partir dessas técnicas foi possível correlacionar os dados obtidos em fontes documentais e empíricas, o que oportunizou o entendimento mais aprofundado e contextualizado da área de estudo do PEC e da temática abordada. Dando continuidade, foram elaborados os mapas empregados na pesquisa (área de estudo, localização do 
geopatrimônio, alvos de conservação e geomorfologia), os quais foram elaborados com a supervisão de um especialista em geoprocessamento, tendo como referência a base cartográfica obtida durante a pesquisa documental e imagens de satélite do Google Earth. A parte de campo, baseada por GPS de precisão, corresponde ao levantamento de dados no próprio local onde os fenômenos ocorrem, nesse caso, o Parque Estadual das Carnaúbas. Foi realizada em duas etapas, uma no ano de 2015 e outra em 2016, totalizando cerca de 20 dias, com o objetivo de compreender melhor as características naturais da área de estudo, bem como identificar, georreferenciar e fazer o registro fotográfico dos atrativos de base natural e cultural

\section{RESULTADOS E DISCUSSÃO}

A Organização das Nações Unidas (ONU) determinou que 2017 será o Ano Internacional do Turismo Sustentável para o Desenvolvimento. Em meio a essas riquezas naturais se encontra a sua vertente geológica, com as conexões com a história e cultura local. Assim, surgindo um campo turístico relativamente novo no Brasil se comparado aos demais países, principalmente europeus: o Geoturismo.

Na definição de Ruschmann (2004), “Geoturismo é um segmento da atividade turística que utiliza de forma sustentável o patrimônio natural e cultural de uma região buscando, além de sua conservação, a formação de uma consciência ambientalista, através da interpretação do ambiente e da promoção do bemestar das populações envolvidas".

Sob o enfoque em tela, a área de abrangência do Parque apresenta características geomorfológicas truncadas por superfície erosiva desenvolvida sob condições de morfogênese mecânica, traduzindo- se no sistema ambiental da Depressão Sertaneja. Exibe uma superfície topográfica aplainada a moderadamente dissecada, com solos rasos e grande ocorrência de afloramentos rochosos, como mostrado na figura 1.

Figura 1: Painel interpretativo, com destaque em vermelho de um trecho da Trilha das Serra das Flores e com destaque do círculo em azul para a Gruta da Pirapora

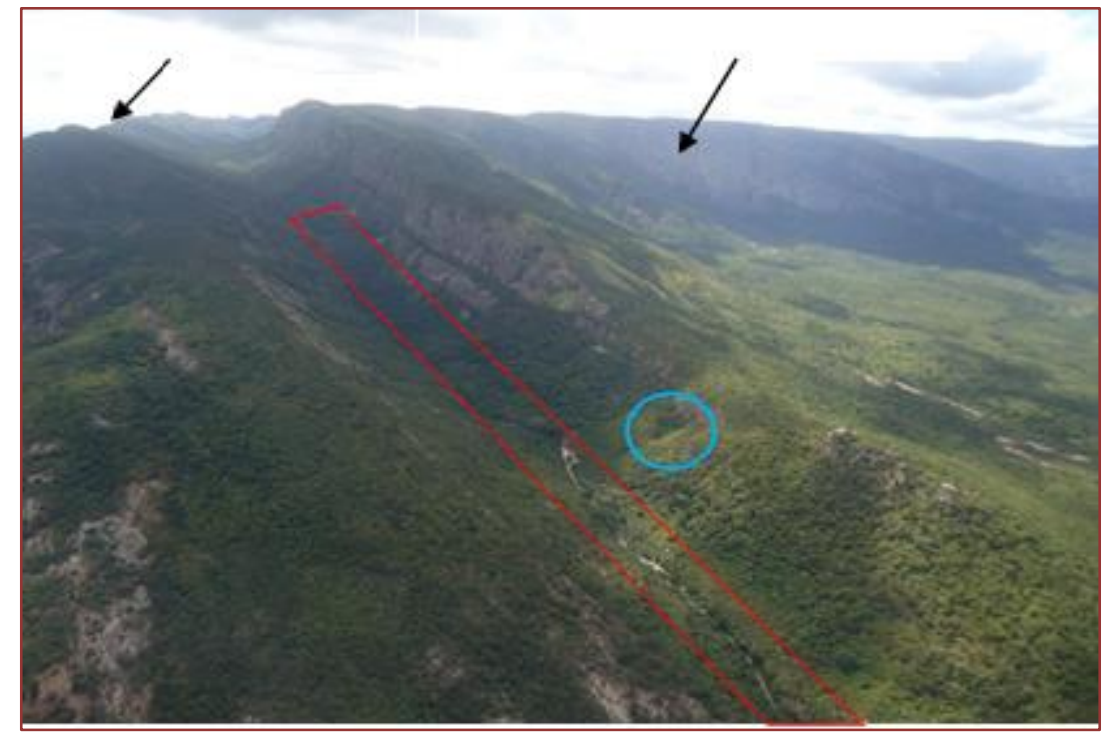

Fonte: 0 autor (2017)

Com esses recortes geológicos, o Parque configura diversos atrativos para as pessoas se deslocarem de seu entorno habitual, precisam de motivação, políticas públicas que despertem seu interesse. Observou-se que em relação à Gruta da Pirapora, ainda falta mais pesquisa e informação para um manejo correto e de forma sustentável.

Todo esse geopatrimônio observado no PEC está intimamente relacionado à definição de sítios geomorfológicos, os geomorfossítios, cujas formas de relevo e depósitos correlatos, isoladamente ou em conjunto, devem ser representativas de determinados processos morfogenéticos (VIEIRA e CUNHA, 2004). Panizza (2001) conceitua os geomorfossítios como as formas de relevo que adquiriram um valor científico, cultural/histórico, estético e/ou socioeconômico, devido à percepção humana ou exploração. 
Com essas considerações arrazoadas, percebe-se que uma política de incentivo ao geoturismo no PEC se viabiliza em uma grande oportunidade de preconizar a preservação e a educação ambiental para a comunidade do entorno e visitantes. Para isso, foi necessário mapear a representatividade e valor ambiental desse produto geoturístico que é a Trilha supracitada, referenciada no quadro abaixo.

Figura 2: Perfil em vermelho da Trilha da Serra das Flores, com o desenho da poligonal do PEC, em amarelo

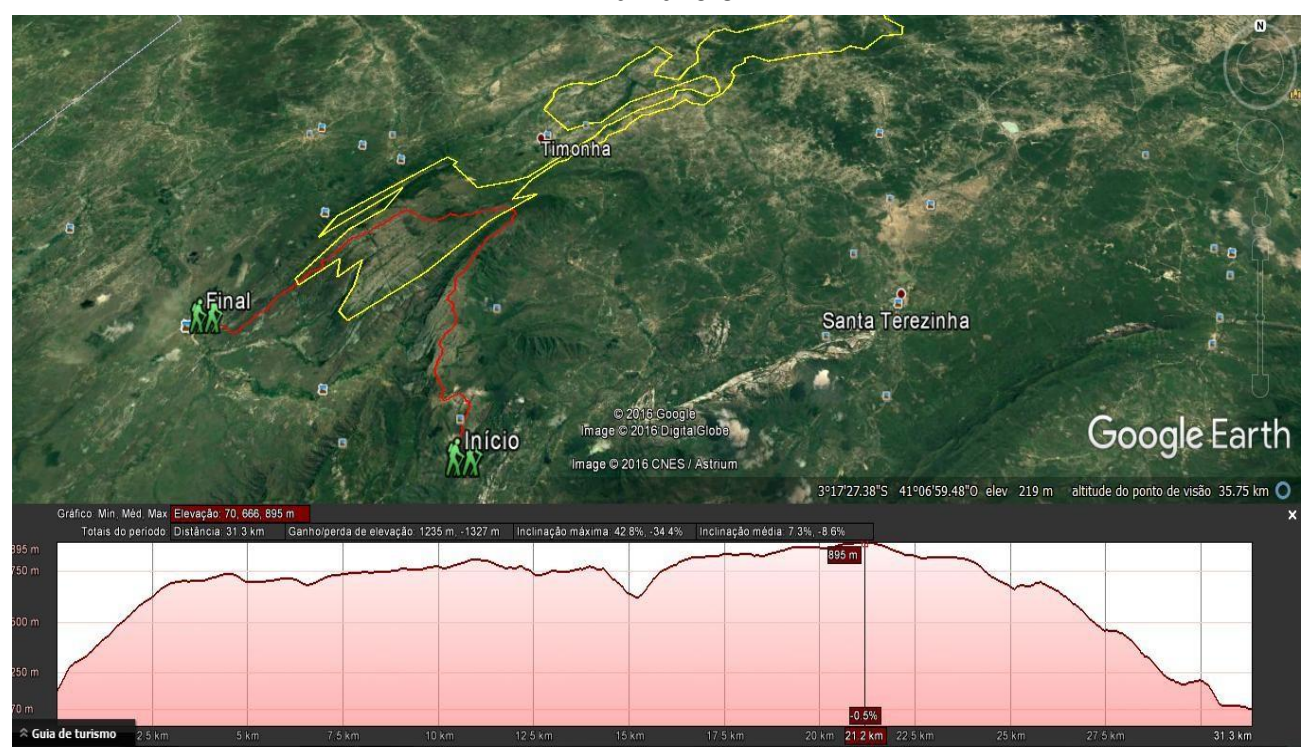

Fonte: O Autor (2017)

Já, em relação à Figura 2, pode-se confirmar pela interpretação do mapa em tela, que o início da trilha se deu na cota $162 \mathrm{~m}$, no distrito de Passagem da Onça, do município de Viçosa/CE, chegando ao topo na cota $895 \mathrm{~m}$. A trilha percorrida na modalidade de trekking tem grau de dificuldade considerada alta, pois o seu percurso é entorno de $31,3 \mathrm{~km}$, com um aclive íngreme. 0 término da trilha se situa no distrito de Ubatuba, do município de Granja/CE.

\section{CONCLUSÕES}

Compreendeu-se que a proposta da Trilha da Serra das Flores é relevante como um produto geoturístico e que aproveitamento dos diferentes conteúdos da geodiversidade sob diversos potenciais de uso pode, inclusive, conferir à paisagem do PEC novas funcionalidades, serviços ecossistêmicos integrados, dinâmicas econômicas e transformação social da realidade local.

Espera-se o fomento de políticas públicas nesta área e que os trabalhos na região do Parque continuem e favoreçam a compreensão de seu valor ambiental, cultural e científico, além de estimular a realização de mais atividades de pesquisa e ensino em geomofossítios, envolvendo todoeste geopatrimônio e acabe por aumentar o reconhecimento dos benefícios da preservação na população local e nos visitantes.

Constatou-se ao longo da pesquisa que a análise integrada dos atrativos naturais e culturais, baseada na metodologia adotada do conjunto de informações levantadas sobre a área de estudo, bem como a base de geodiversidade dos elementos envolvidos, suas devidas sobreposições e os perfis geoecológicos, juntamente com um reconhecimento de campo, favoreçam a compreensão de seu valor ambiental e científico para a manutenção dos serviços ecossistêmicos da Chapada da Ibiapaba. 


\section{REFERÊNCIAS}

[1] Eberhard, R. Pattern and process: towards a regional approach to national estate assessment of geodiversity. Technical Series, n. 2. Australian Heritage Commission; Environment Forest Taskforce, Environment Australia, Canberra, 1997.

[2] Gray, M. Geodiversity: valuing and conserving abiotic nature. Jonh Wiley \& Sons Ltd. Londres/Inglaterra, 434 p. 2004.

[3] Lakatos, E. M.; Marconi, M. de A. Fundamentos de metodologia científica. 5. ed. São Paulo: Atlas, 2003.

[4] Panizza, M. Geomorphosites: concepts, methods and examples of geomorphological survey. Chinese Science Bulletin, v. 46, Supp, p. 4-5, 2001.

[5] Ruschmann, D. V. de M. Turismo e planejamento sustentável: a proteção do meio ambiente. 11 ed. Campinas: Papirus. (Coleção Turismo). 2004.

[6] Vieira, A.; Cunha, L. Patrimônio geomorfológico: tentativa de sistematização. In: III Seminário Latino Americano de Geografia Física, Puerto Vallarta, México. 2004. Disponível em: < http://georeferencias.no.sapo.pt/VieiraCunha-PatrimonioGeomorf.pdf>. Acesso em: 15 de abril de 2017. 


\title{
Capítulo 5
}

Migração sazonal de trabalhadores do semiárido com destino aos canaviais

\author{
Wallysson Klebson de Medeiros Silva \\ Daisy Caroline Nascimento Pereira \\ Jean Carlos dos Santos \\ Susane Eterna Leite Medeiros \\ Raniela Alves Targino \\ Emanuel Jhonata Gomes da Silveira
}

Resumo: Nos últimos anos, o cenário para o setor sucroalcooleiro tem melhorado significativamente, pois o Brasil é o maior produtor mundial de açúcar e o segundo maior produtor de etanol. Diante desse cenário, o número pessoas saindo do semiárido em busca de melhores condições socioeconômicas vem potencializando a migração de forma sazonal, para os canaviais. 0 desenvolvimento dessa pesquisa buscou investigar as migrações e as condições de trabalho, na cultura canavieira, a partir de uma ótica paradoxal. Enquanto cresce o mercado sucroalcooleiro, a condição de vida dos trabalhadores da cana parece piorar a cada ano. Com vistas a uma análise mais ampla, acerca do setor sucroalcooleiro e suas condições de trabalho, o objetivo geral deste artigo foi: conhecer os aspectos gerais do setor sucroalcooleiro e os principais impactos da atividade no trabalhador, que migram de forma sazonal do semiárido para trabalhar nos canaviais. Os objetivos específicos que nortearam esse artigo foram: apresentar brevemente a atual situação do setor sucroalcooleiro brasileiro; analisar a migração sazonal dos trabalhadores do semiárido para os canaviais e realizar um panorama das condições do trabalho canavieiro e suas necessidades. Para alcançar o objetivo proposto, o procedimento metodológico da pesquisa foi de caráter descritivo, com base nos objetivos, sendo utilizada a investigação bibliográfica e análise de dados secundários. A análise e discussão dos resultados mostram que mesmo com grande incremento, tanto na produção, quanto na economia, o trabalho no setor sucroalcooleiro continua inseguro e a saúde dos trabalhadores deteriorandose. 0 cenário que ora se apresenta e as perspectivas futuras do setor recomendam que este seja um período oportuno, para se compactuar com uma reversão no quadro das relações de trabalho, no setor do país, visto que o setor só cresce economicamente e regride, no âmbito trabalhista. Faz-se necessário uma política pública eficiente nos locais de origem desses trabalhadores, de maneira a criar oportunidades de emprego e renda.

Palavras-chave: Semiárido. Setor Sucroalcooleiro. Migração. Condições de Trabalho. 


\section{INTRODUÇÃO}

Tradicionalmente, a seca tem sido indicada como o principal motivo da migração. Tribos indígenas que residiram a região antes da chegada dos portugueses viam-se constantemente forçadas a migrar, devido as secas. Os colonizadores portugueses também foram obrigados a saírem dos seus locais de abrigo, em razão das secas até a ocupação definitiva do "nordeste interior" (ANDRADE, 2010). Contudo, na contemporaneidade, a seca deixou de ser o principal fator da migração, tornando-se uma razão secundária e assim deve ser analisada. A má distribuição das terras é o determinante principal da migração (ALMEIDA, 2010).

Nos últimos anos, o cenário para o setor sucroalcooleiro tem melhorado significativamente, pois o Brasil é o maior produtor mundial de açúcar e o segundo maior produtor de etanol. Diante desse cenário, o número de pessoas em busca de melhores condições socioeconômicas vem potencializando a migração de forma sazonal para os canaviais, sendo fortalecido pela necessidade de um aumento da mão-de-obra e uma maior conscientização de empregadores, os quais vêm cada vez mais respeitar às novas legislações ${ }^{1}$, com objetivo de diminuir os acidentes e doenças ocupacionais nos canaviais.

Paralelamente a isso, cabe ressaltar que a exploração nos canaviais ainda não é página virada na história do Brasil, tendo em vista que, o Ministério do Trabalho vem encontrando indícios de trabalho análogo à escravidão ${ }^{2}$, no setor sucroalcooleiro, em todos os estados do Brasil (MTE, 1999). Sendo assim, o trabalhador desse setor, vem sendo marcado, desde o corte até a produção, com jornadas exaustivas, desgaste corporal e psicológico, pagamento por produtividade, falta de equipamentos de segurança e submetidos a todos os tipos de intempéries.

Com vistas a uma análise mais ampla acerca do setor sucroalcooleiro e suas condições de trabalho, o objetivo geral deste artigo foi: Conhecer os aspectos gerais do setor sucroalcooleiro e os principais impactos da atividade no trabalhador que migram de forma sazonal do semiárido para trabalhar nos canaviais. Os objetivos específicos que nortearam esse artigo foram: Apresentar brevemente a atual situação do setor sucroalcooleiro brasileiro; Analisar a migração sazonal dos trabalhadores do semiárido para os canaviais e Realizar um panorama das condições do trabalho canavieiro e suas necessidades.

\section{METODOLOGIA}

O objeto de estudo dessa pesquisa foi o semiárido brasileiro, cuja região abrange partes dos estados de Alagoas, Bahia, Ceará, Minas Gerais, Paraíba, Pernambuco, Piauí, Rio Grande do Norte e Sergipe, com uma área de 982.563,3 km² (BRASIL, 2005).

Os procedimentos metodológicos utilizados neste estudo, além de ser bibliográfico, foi também descritivo, onde foi realizado um levantamento por meio de dados secundários junto às instituições como Instituto Brasileiro de Geografia e Estatística (IBGE), Companhia Nacional de Abastecimento (CONAB) e Ministério da Agricultura, Pecuária e Abastecimento (MAPA).

A pesquisa descritiva, tornou-se fundamental para o artigo, uma vez que proporcionou um maior conhecimento sobre o tema, uma maior descrição dos fenômenos ocorridos e seus determinantes, facilitando, assim, encontrar respostas para os objetivos propostos.

Quanto à pesquisa bibliográfica Gil (2008, p. 44), estabelece que “[...] a pesquisa bibliográfica é desenvolvida com base em material já elaborado, constituído principalmente de livros e artigos científicos". A pesquisa bibliográfica permitiu descrever de forma detalhada o conteúdo estudado, através de material já elaborado como: livros, artigos científicos, teses, dissertações, periódicos e etc.

\section{RESULTADOS E DISCUSSÃO}

\subsection{ATUAL SITUAÇÃO DO SETOR SUCROALCOOLEIRO}

\footnotetext{
${ }^{1}$ A Norma Reguladora ${ }^{\circ}$ 31, trata da segurança e da saúde na agricultura, pecuária, silvicultura, exploração florestal e aquicultura, cujo escopo, é estabelecer princípios a serem observados no meio ambiente do trabalho rural (BRASIL, 2005).

2 Segundo o Artigo 149 do Código Penal, a condição trabalhista "análoga á de escravo", é um crime contra a dignidade humana.
} 
Nos últimos anos, o cenário para o setor sucroalcooleiro tem melhorado significativamente. O Brasil é o maior produtor mundial de açúcar e o segundo maior produtor de etanol, ficando atrás apenas dos EUA. A produção de ambos os produtos, concentra-se na região Centro-Sul do país. Conforme o Mapa (2016), o número de unidades em operação em dezembro de 2015 era 376, equivalendo a uma capacidade de moagem efetiva, de cerca de 750 milhões de toneladas. Conforme avaliações da Conab (2017), a produtividade média do país aumentou 1,5\% na safra 2017/18 com relação à anterior, atingindo 73,7 tc/ha.

De acordo com a Conab (2017), a produção estimada da cana-de-açúcar na safra 2017/18 foi de 646,4 milhões toneladas, deste total, $54 \%$ é produzido em São Paulo. No que diz respeito a produção do açúcar, o centro-sul corresponde a $91,7 \%$ da produção, enquanto que a região nordeste representa apenas 8,2\%. A distribuição da produção por estado indica que os estados do Paraná, São Paulo, Minas Gerais, Goiás e Alagoas, são os maiores produtores do açúcar. Por sua vez, a produção total de etanol foi de 26,12 bilhões de litros, na safra 2017/18. Na figura 1, pode-se observar a produção de cana-de-açúcar e percentual destinado ao etanol e açúcar no Brasil.

Podemos observar que o percentual indicado para a fabricação de açúcar será maior que o do ano anterior, de 47,88\% versus 45,91\%; ao mesmo tempo que o percentual atribuído para a produção de etanol será inferior, de 52,12\% contra 54,09\%. Sobre duas safras seguidas, percebeu-se um crescimento no percentual de cana-de-açúcar determinado para a produção de açúcar devido aos maiores rendimentos obtidos com a venda do adoçante.

De acordo com Vilela et al. (2010) "a importância estratégica do setor sucroalcooleiro na economia nacional é manifestada não somente na produção, consumo e exportação de seus produtos, mas também na ação da matriz energética brasileira que é crescente". Com base nessa análise, percebe-se que o setor sucroalcooleiro vem crescendo e se consolidando a cada ano. Em decorrência de sua contribuição, para os combustíveis usados no transporte e bioeletricidade. Tal fato colabora para o aumento do número de migrantes para a região canavieira.

Figura 1. Produção de cana-de-açúcar e percentual destinado ao etanol e açúcar no Brasil

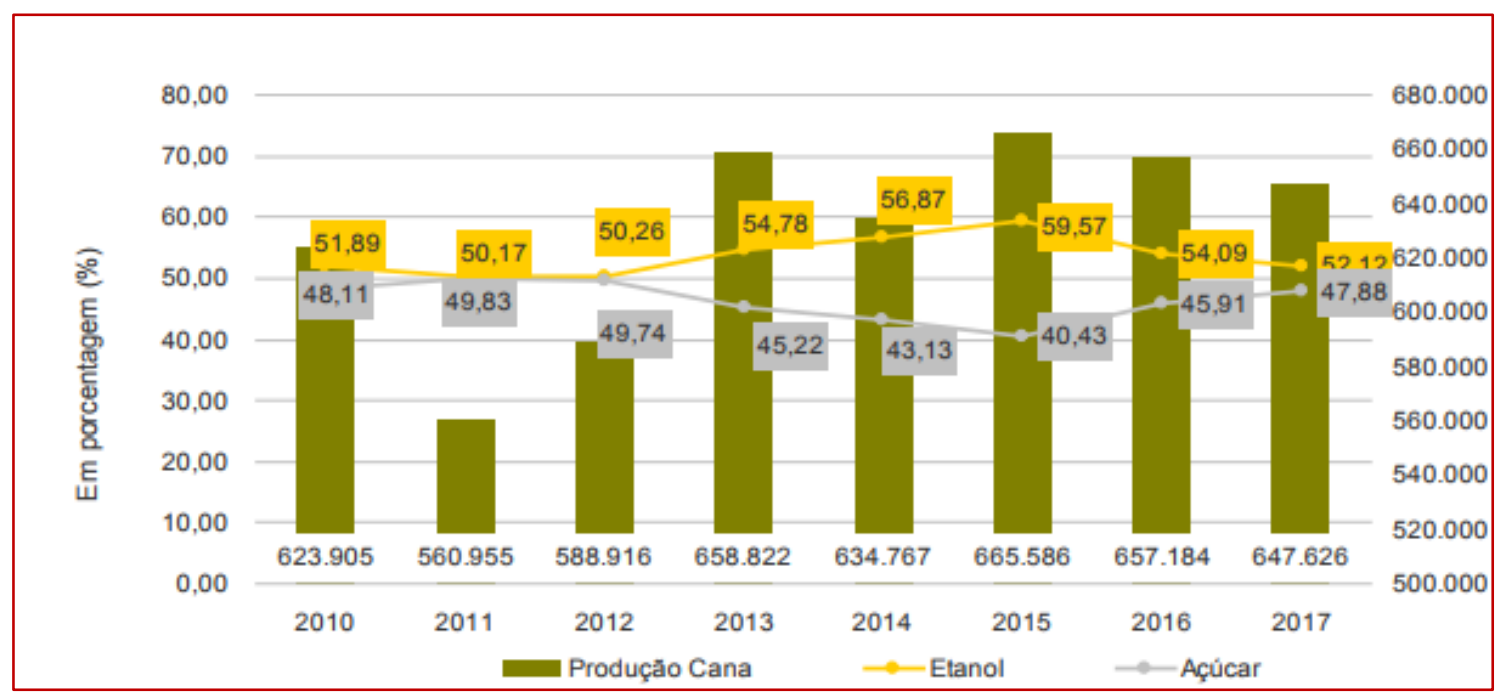

Fonte: CONAB (2017)

\subsection{MIGRAÇÃO SAZONAL DO SEMIÁRIDO PARA OS CANAVIAIS}

As grandes migrações sazonais no Nordeste brasileiro começaram ao fim do século XIX e começo do século XX, com destino principal a Zona da Mata, as capitais e outras regiões do País. O perfil do migrante é predominantemente pobre, jovem, desempregado e camponês com pouca terra. De acordo com Caron (2003, p. 93) "há situações em que a migração garante a sobrevivência de muitas famílias camponesas durante uma parte do ano, é fonte regular de renda, de estabilidade e de redução de riscos”. Ao migrar do 
semiárido para os canaviais, o sertanejo ${ }^{3}$ tem sua rotina alterada, seu corpo passa a ser resignado a uma dura disciplina, sendo muitas vezes vigiado, da mesma maneira que exigido de forma cruel. 0 corte da cana-de-açúcar requer prática com o trabalho bruto, pede corpos apropriados para fortes e duras jornadas laborais (ALBUQUERQUE; CANIELO, 2011).

Deste modo, o migrante que parte do semiárido (principalmente do sertão) em direção aos canavieiros, tem como objetivo conseguir juntar um bom valor em dinheiro, para com isso assegurar a sua reprodução e a da sua família e garantir a manutenção e o aperfeiçoamento de sua propriedade. No momento atual, devido as mudanças trabalhistas, a exemplo do recebimento de um seguro desemprego a cada duas safras, contribui para intensificar a migração (ALBUQUERQUE; CANIELO, 2011).

Desta maneira, o setor sucroalcooleiro é responsável por gerar 1,2 milhão de empregos direto. Sendo que desse total, 300 mil são cortadores de cana. 0 perfil do cortador é migrante e de baixa escolaridade e sua participação no setor sucroalcooleiro é sazonal, pois costuma deixar a sua cidade de origem somente durante o período da colheita de cana. Geralmente, como mostrado na Figura 2, a maioria dos migrantes sai do Nordeste ou do Vale do Jequitinhonha em Minas Gerais, em direção ao interior de São Paulo, que é o maior produtor do país (ONG, 2015). Segundo Gonçalves (2001) os principais locais de origem dos migrantes sazonais são os estados da Paraíba, Ceará e Bahia, ao mesmo tempo que São Paulo, Mato Grosso do Sul e Pernambuco são os principais destinos desses trabalhadores.

Figura 2. Migração sazonal dos cortadores de cana

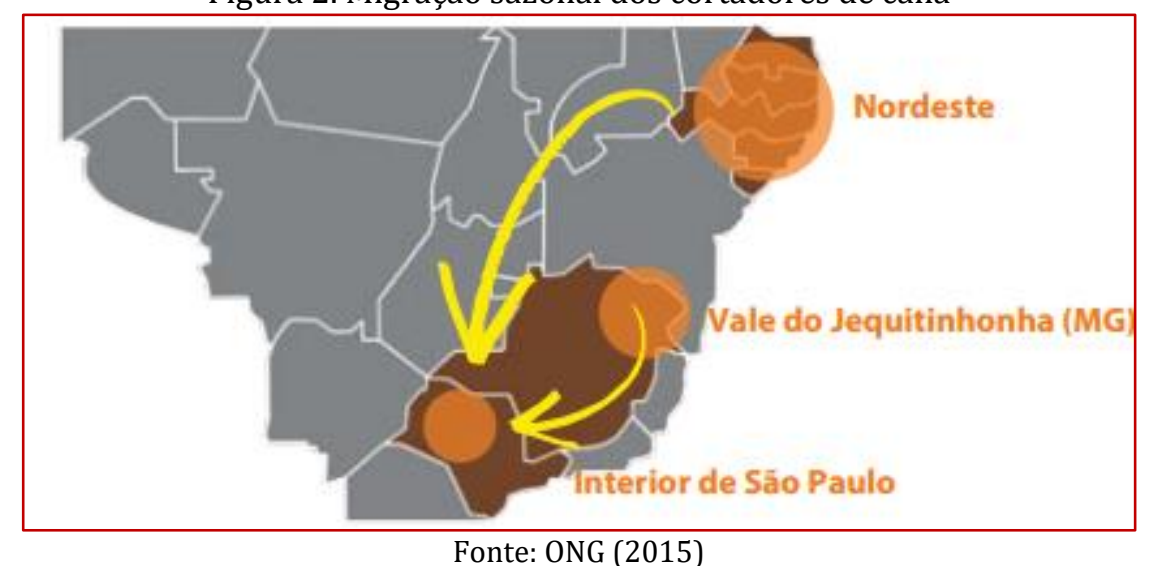

De acordo com Silva (2012, p. 49), a expansão da cana-de-açúcar tem colaborado para migração de trabalhadores do semiárido nordestino, principalmente para os canaviais paulistas, sendo considerados "gente que veio de longe, atraídos, dizem alguns pelo ouro verde da cana; iludidos, dizem outros pelo apelo das mil e uma mercadorias que lhes acenam com a promessa de felicidade; empurrados, dizem ainda outros, pela fome e pela miséria de suas regiões de origem". Assim, esse processo cruel não está conexo a liberdade do indivíduo, mas as estruturas que o impulsionam (CARMO, 2012).

Apesar disso, observa-se nos últimos anos, uma diminuição de migrações sozonais. A Figura 3, destaca que o crescimento da população residente pode ser empregado como proxy para sugerir essas mudanças (Figura 3a). Constata-se que boa parte da população do semiárido (848) cresceu entre 2000 e 2010. Além disso, houve uma ampliação na taxa de urbanização (Figura 3b). Um dos fatores para que isso venha acontecendo, é o crescente movimento entre origem e destino mais próximos, ocasionado por causas de atração (melhores condições socioeconômicas) do que por fatores clássicos de expulsão (seca, renda, trabalho etc.) (BUAINAIN; GARCIA, 2013).

\footnotetext{
${ }^{3}$ Nome dado a todos os migrantes que partem do semiárido nordestino para os canaviais.
} 
Figura 3. a) Variação percentual da população residente por munícipio do semiárido 2000-2010 e b) Taxa de urbanização dos municípios do semiárido em 2010

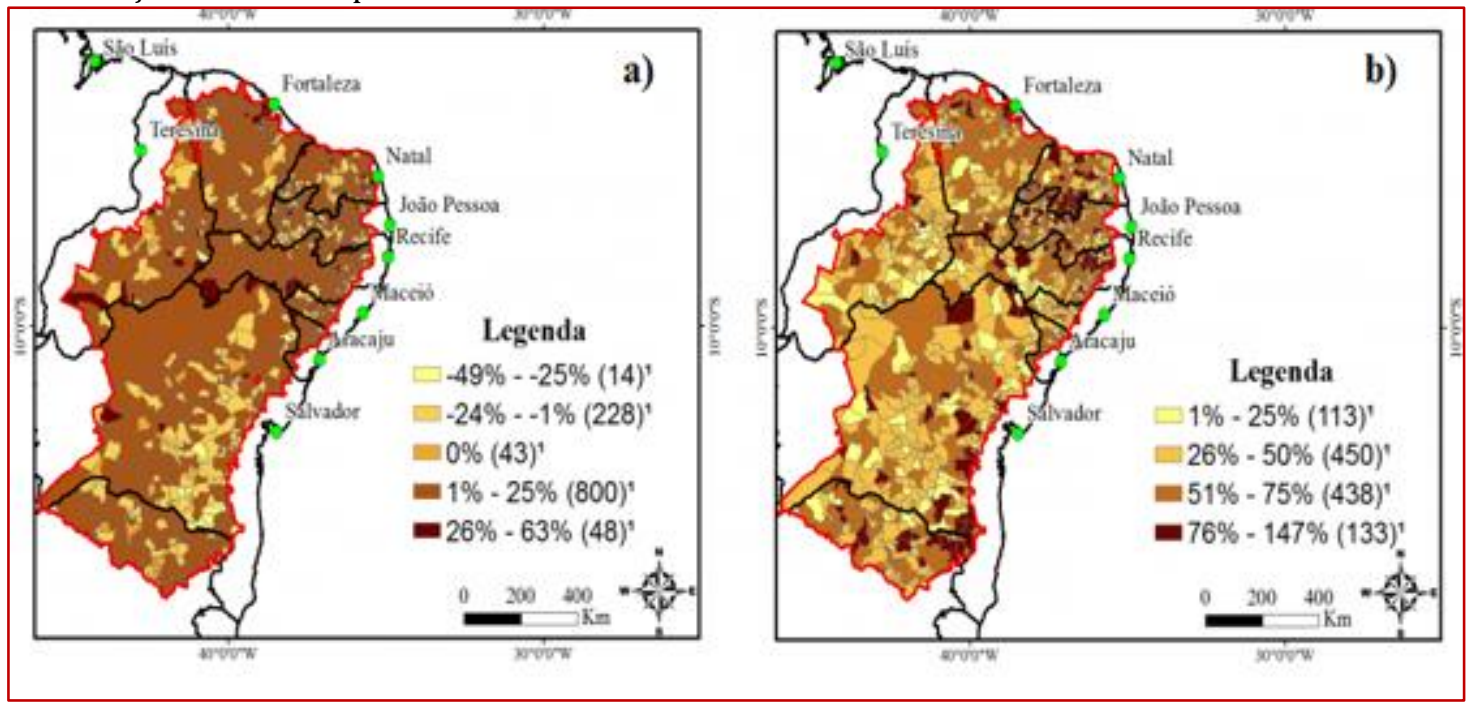

Fonte: Buainain e Garcia (2013) com base no IBGE (2010)

\subsection{AS RELAÇõES E CONDIÇõES DE TRABALHO DO MIGRANTE NOS CANAVIAIS}

Devido a vulnerabilidade dos trabalhadores que migram do seu município de origem em busca de melhores condições sociais e econômicas, faz com que os mesmos, tornam-se suscetíveis ao trabalho análogo a escravidão.

As seleções dos cortadores de cana-de-açúcar usualmente são realizadas por agenciadores, que são as pessoas responsáveis para contratar esses trabalhadores, geralmente buscam pessoas fortes e com bastante resistência para o trabalho exaustivo (MOREIRA et al., 2001). Mesmo o corte de cana-de-açúcar sendo um trabalho muito desgastante e exaustivo, é a única renda de um grande número de trabalhadores, que devido ao baixo nível educacional, encontram no corte de cana, uma maneira de garantir o sustento da família (ALVARENGA; QUEIROZ, 2008). Logo, as condições de trabalho no setor sucroalcooleiro são marcadas pelo aumento da produtividade estabelecida.

Esses imigrantes longe de casa e de suas famílias ficam alojados em casas no meio dos próprios canaviais ou na periferia das cidades, provocando diversos problemas de infraestrutura urbana e rural. 0 agenciador tem sua remuneração baseada na produtividade dos trabalhadores, que é a produção per capita, isso o leva a pressionar os trabalhadores a jornadas exaustivas de $10 \mathrm{~h}$ a $12 \mathrm{~h}$ diárias e muitas vezes os trabalhadores são roubados no peso da produção de cana. Além disso, os ônibus que transportam os trabalhadores são dos agenciadores, assim ele consegue ter maior controle do meio de trabalho, com isso muitos vão trabalhar doentes para não perder a produção (SILVA, 2008).

A contratação da mão de obra é feita desde a fase de preparação de mudas, passando pelo combate as formigas, colheita manual até a retirada das sobras, que é feita após o corte da cana, onde a parte que mais demanda trabalhadores é a colheita. De maneira geral, os trabalhadores recebem por produtividade, o que leva os trabalhadores a chegarem aos seus limites, em busca de aumentar sua produtividade e seu rendimento mensal. Sendo o corte de cana-de-açúcar uma atividade muito árdua e exaustiva, provoca uma redução na expectativa de vida dos trabalhadores, em torno de 10 anos (RODRIGUES; ORTIZ, 2006).

A relação de trabalho torna-se evidente por uma série de problemas, que acontecem desde o alojamento dos trabalhadores na usina, até a carência de condições de higiene e limpeza, o comparecimento da figura do agenciador que manda, organiza e recruta os trabalhadores para o setor sucroalcooleiro, o controle do número de cana colhida, os custos de manutenção desse trabalhador e do suporte a família que o mesmo deixou em sua região de origem, as dívidas derivadas da viagem, a falta de assistência médica ao longo de seu período de trabalho, as relações sociais, as jornadas excessivas e uma série de outros fatores determinantes que contribuem para a diminuição da qualidade do trabalho (SPECIAN; FIGUEIREDO, 2010).

Assim, as condições de trabalho nas lavouras são consideradas medievais, pois o corte da cana ainda é feito de maneira manual, repetitivo e exaustivo. Além disso, os canavieiros trabalham em condições 
precárias, visto que o corte de cana normalmente é feito sobre sol forte, durante todo dia, sem muita proteção.

0 reflexo disso é a média de extração por cortador de cana, em 1960 era de 2 toneladas/dia, em 1980 subiu para 8 toneladas/dia e atualmente chega a 12 toneladas/dias. Isso ocorre devido à competição com as máquinas, horas extras e trabalho por produção. Ao final do expediente, estudos estipulam que os trabalhadores perdem em média oito litros de água, fazendo com que muitos acabem falecendo por parada cardíaca. Logo, o equipamento de proteção individual (EPI) é de extrema importância na tentativa de reduzir os possíveis acidentes de trabalho, que são: boné com abas, luvas, botinas ${ }_{\llcorner}$perneiras, óculos etc (RONQUIM, 2010).

Baseado no estudo "por que morrem os cortadores", de Francisco Alves, averiguamos a discrepância e injustiças que esse setor oferece aos trabalhadores. Atualmente, os migrantes cortam em média 12 toneladas de cana por dia, caminham 8,8 quilômetros, desfere 133.332 golpes de facão, faz 36.630 flexões e giros no corpo e perde 8 litros de água (ALVES, 2006).

Entre 2003 e 2013, fiscais do trabalho resgataram 10.709 trabalhadores canavieiros, em condições análogas ás de escravos. Porém, historicamente esse número vem diminuindo, devido as pressões sociais, mídias e aumento das fiscalizações, contribuindo para redução de trabalho análogo e irregularidades trabalhistas (ONG, 2015).

\section{CONCLUSÕES}

Mediante o desenvolvimento deste artigo, tornou-se possível refletir acerca das dinâmicas socioespaciais dos trabalhadores migrantes vindo do semiárido aos canaviais. Desta maneira, conclui-se que:

- - A migração sazonal tornou-se uma estratégia de reprodução e sobrevivência de diversas famílias semiáridas, como forma de melhorar suas condições socioeconômicas,

- - A migração geralmente ocorre devido a fatores de "expulsão", ocasionados nas localidades de origem, devido a estagnação econômica, seca, falta de emprego, baixa produtividade de terra etc.

- - Para receber mais, os migrantes acabam trabalhando mais, chegando a sua exaustão e consequentemente a condições análogas à escravidão.

- $\quad$ - 0 custo da mão de obra migrante é extremamente baixo, ao analisar o lucro que os grandes empresários recebem com a produção de álcool e tanto outros produtos, que é possível produzirem com a cana-de-açúcar, como os ácidos, aguardente, rum etc, se torna algo surreal.

- $\quad$ - O movimento migratório é significativo para todos os agentes do processo, por essa razão é tão forte e sem expectativas de acabar, excetuando-se pela mecanização crescente, que mesmo assim não atingirá todas as áreas dos canaviais.

- $\quad$ - Torna-se fundamental uma política pública eficiente, nos locais de origem dos trabalhadores migrantes, de maneira a criar oportunidades de emprego e renda.

- - Faz-se necessário criar ações na perspectiva de que os sertanejos sejam protagonistas na realidade onde vivem, em consenso com sua cultura, crença, costumes e valores.

\section{REFERÊNCIAS}

[1] Albuquerque, C. F.; Canielo, M. M. Migração: a amarga vida de canavieiro do camponês do Semiárido. Latitude, v. 5, n. $\quad$ 1, p. 113-131, 2011. Disponível $\quad$ em: http://www.seer.ufal.br/index.php/latitude/article/view/1001>. Acesso em: 27 mar. 2019.

[2] Almeida, L. S. Manuel Correia de Andrade: os empobrecidos e a terra. Revista economia política do desenvolvimento, v. 3, Edição Especial, p. 9-44, 2010. Disponível em: < http://www.seer.ufal.br/index.php/repd/article/view/149>. Acesso em: 27 mar. 2019.

[3] Alvarenga, R. P. Queiroz, T. R. Caracterização dos aspectos e impactos econômicos, sociais e ambientais do setor sucroalcooleiro paulista. In: XLVI Congresso da sociedade brasileira de economia, administração e sociologia rural - Sober, 2008, Rio Branco. Anais... Rio Branco: UFAC, 2008. Disponível em: < https://ageconsearch.umn.edu/bitstream/113960/2/691.pdf>. Acesso em: 27 mar. 2019.

[4] Alves, F. Por que morrem os cortadores de cana. Saúde e Sociedade, v. 15, n. 3, p. 90-98, 2006. Disponível em: < http://www.scielo.br/scielo.php?script=sci_arttext\&pid=S0104-12902006000300008>. Acesso em: 27 mar. 2019. 
[5] Andrade, Lopes. Introdução à sociologia da seca. Fortaleza: Banco do Nordeste, 2010.

[6] Brasil. Ministério da integração nacional. Relatório final grupo de trabalho interministerial para redelimitação do semi-árido nordestino e do polígono das secas. Brasília: MIN, 2005. Disponível em: < http://www.cpatsa.embrapa.br/public_eletronica/downloads/OPB1839.pdf>. Acesso em: 27 mar. 2019.

[7] Buainain, A. M.; Garcia, J. R. Desenvolvimento rural do semiárido brasileiro: transformações recentes, desafios e perspectivas. Confins (Paris), $\quad$ v. 1, p. 1, 2013. Disponível em: < https://journals.openedition.org/confins/8633?lang=pt>. Acesso em: 27 mar. 2019.

[8] Carmo, M. A. A. Migrações temporárias e as relações de trabalho no campo: o caso da cafeicultura no cerrado. In: XXI Encontro nacional de geografia agrária, 2012, Uberlândia. Anais... Uberlândia: UFU, 2012. Disponível em: < http://www.lagea.ig.ufu.br/xx1enga/anais_enga_2012/eixos/1402_1.pdf>. Acesso em: 27 mar. 2019.

[9] Conab, Companhia Nacional de Abastecimento. Acompanhamento da safra brasileira de cana-de-açúcar. v. 4, safra 2017/18, n. 2, 2017. Disponível em: <www.conab.gov.br>. Acesso em: 27 mar. 2019.

[10] Caron, Patrick; Sabourin, Eric. Camponeses do sertão: mutação das agriculturas familiares no Nordeste do Brasil. Brasília, DF: Embrapa Informação Tecnológica, 2003. Disponível em: < http://agritrop.cirad.fr/519181/>. Acesso em: 27 mar. 2019.

[11] ONG Repórter Brasil. Escravo, nem pensar!:uma abordagem sobre trabalho escravo contemporâneo na sala de aula e na comunidade. As condições de trabalho no setor sucroalcooleiro/ Repórter Brasil (Programa Escravo, nem pensar!) - São Paulo: Repórter Brasil, 2015. Disponível em: < https://reporterbrasil.org.br/wpcontent/uploads/2015/02/livro_escravo_nem_pensar_baixa_final.pdf>. Acesso em: 27 mar. 2019.

[12] Gil, Antonio Carlos. Como elaborar projetos de pesquisa. 4. ed. São Paulo: Atlas, 2008.

[13] Gonçalves, J. A. Migrações internas: Evoluções e desafios. Estudos Avançados. Brasília, 2001.

[14] Mapa, Ministério da Agricultura, Pecuária e Abastecimento. Acompanhamento da produção sucroalcooleira. Levantamento da Safra 2016. Disponível em: <www.agricultura.gov.br/acesso-a-informacao/acoes-eprogramas/cartas-de-servico/politica-de-agroenergia/acompanhamento-da-producao-sucroalcooleira>. Acesso em: 27 mar. 2019.

[15] Moreira, Emília. et al. A visão dos atores sociais sobre a crise do emprego rural na zona canavieira da Paraíba. Revista da ABET, v. I, n. 1-2, p. 40-65, $2001 . \quad$ Disponível em: <http://www.periodicos.ufpb.br/ojs/index.php/abet/article/view/15425>. Acesso em: 27 mar. 2019.

[16] Mte, Ministério do Trabalho e Emprego. Mapa do indicativo do Trabalho da Criança e do Adolescente. Brasília, DF, 1999.

[17] Rodrigues, D.; Ortiz, L. Em direção à sustentabilidade da produção de etanol de cana-de-açúcar no Brasil. 2006. Disponível em: <http://www.vitaecivilis.org.br/anexos/etanol_sustentabilidade.pdf>. Acesso em: 27 mar. 2019.

[18] Ronquim, Carlos Cesar. Queimada na colheita de cana-de-açúcar: impactos ambientais, sociais e econômicos. Embrapa Monitoramento por Satélite, Documentos 77. p. 45, 2010. Disponível em: < https://www.embrapa.br/buscade-publicacoes/-/publicacao/878010/queimadas-na-colheita-da-cana-de-acucar-impactos-ambientais-sociais-eeconomicos>. Acesso em: 27 mar. 2019.

[19] Silva, M. S. Trabalhadores migrantes nos canaviais paulistas: Sociabilidades, condições de trabalho e formas de resistência!. 2012. 321 f. Tese (Doutorado em Ciências Sociais) - Centro de Humanidades, Universidade Federal de Campina Grande, Campina Grande. 2012

[20] Silva, Zelito. Etanol: nesfato impacto social e ambiental. Coordenação do MTL-DI, Goiás, 2008. Disponível em: < https://www.lsr-cit.org/2008/03/31/etanol-nefasto-impacto-social-e-ambiental/>. Acesso em: 27 mar. 2019.

[21] Specian, V.; Figueiredo, M. A. G. O setor sucroalcooleiro e os indicadores da rede de agricultura sustentável para o trabalho no corte da cana: uma possibilidade de aplicação. In: V Enanppas, Encontro nacional da ANPPAS, 2010, Santa Catarina. Anais... Santa Catarina: UFSC, 2010. Disponível em: <https://www.researchgate.net/publication/315665002_O_Setor_Sucroalcooleiro_e_os_Indicadores_da_Rede_de_Agri cultura_Sustentavel_para_o_Trabalho_no_Corte_da_Cana_uma_possibilidade_de_aplicacao $>$. Acesso em: 27 mar. 2019.

[22] Vilela, P. S.; Gomes A. C. A.; Veloso A. F. Evolução e tendências do agronegócio da cana-de-açúcar em Minas Gerais. Belo Horizonte: FAEMIG, 2010. 


\section{Capítulo 6}

Perspectiva de familiares na convivência com os portadores de transtornos mentais

\section{Nivea Mabel Medeiros}

Rita Duarte Brito Dantas

Aissa Romina Silva do Nascimento

Rogênia Araújo Campos

Genicléia Lisboa Rolim

Resumo: 0 cuidado à pessoa com transtorno mental envolve diversas dificuldades a família, que passa a vivenciar situações de preocupação. Desta forma objetivou-se analisar a convivência dos familiares com portadores de saúde mental. Trata-se de um estudo de pesquisa de campo, com abordagem qualiquantitativa e exploratória, desenvolvido no Município de Ipaumirim, CE. A população do estudo foi composta por 16 famílias da UBS Sede I e 6 famílias da UBS Sede II. A amostra foi composta por 10 famílias que convivem com portador de transtornos mentais destas Unidades Básicas de Saúde (UBS).Os resultados demonstram que os familiares são, predominantemente, do sexo feminino e solteiros, de faixa etária entre 30 e 40 anos, com um expressivo percentual de idade acima de 62 anos. Com relação aos dados relevantes do estudo foi possível perceber que a convivência com o portador de transtorno mental é difícil e estressante, principalmente devido à instabilidade do paciente.

Palavras-chave: Enfermagem, Família, Saúde Mental. 


\section{INTRODUÇÃO}

No processo de reabilitação do paciente, a família deve ser considerada como indispensável ator social, uma vez que a efetividade do tratamento psiquiátrico depende do acolhimento e ressocialização do indivíduo. Nesse contexto, a inclusão da família no plano de cuidados oferecido ao paciente amplia a rede comunitária. Contudo, é importante ter em vista que a família também passa por uma profunda reestruturação em sua rotina, de modo que o tratamento e as ações devem ser direcionadas não apenas ao portador de transtornos mentais, mas também à sua família (FERNANDES et al., 2012). Ressalta-se, portanto, a importância da participação da família no tratamento, no sentido de favorecer uma melhor convivência com o portador de transtorno mental, uma vez que, inserida no processo terapêutico, a família tem a oportunidade de compreender a doença e dessa forma, prestar uma melhor assistência.

Ademais, percebe-se uma necessidade de levar mais esclarecimento às famílias, visando favorecer a participação desta no tratamento e, de posse de mais informações acerca da doença e do processo terapêutico, proporcionar uma convivência mais harmônica e positiva para todo o grupo familiar. Com base nesses relatos, esse estudo foi desenvolvido a partir do seguinte questionamento: Qual a perspectiva dos familiares com relação à convivência com portadores de transtorno mental? 0 objetivo deste estudo é, analisar a perspectiva de familiares na convivência com portadores de transtornos mentais. A escolha desse tema se justifica em face da relevância de abordar o papel da família na convivência com o indivíduo portador de transtorno mental, contribuindo para a promoção de cuidados mais adequados às realidades dessa clientela. Além disso, essa pesquisa tem a pretensão de incrementar a literatura específica, lançando novos olhares sobre os aspectos que caracterizam a convivência do portador de transtornos mentais com sua família.

\section{REFERENCIAL TEÓRICO}

\subsection{TRANSTORNOS MENTAIS: UMA ABORDAGEM GERAL}

Os transtornos mentais se apresentam de diversas formas e afetam as pessoas em diferentes graus de severidade, de forma que é possível distinguir entre os portadores, aqueles que ainda são aptos ao trabalho e outras atividades, ao passo que outros se tornam incapacitados para exercer tais funções. Os transtornos mentais caracterizam-se por uma combinação de pensamentos anormais, comportamentos, emoções e relacionamentos com os outros, sendo que para a maioria dessas doenças existem tratamentos eficazes. Os distúrbios mentais estão entre as principais causas de incapacidade no mundo e representam um impacto negativo de grande importância para a vida das pessoas. 0 diagnóstico geralmente ocorre tanto pela análise das características psicológicas, como também por meio dos aspectos ambientais ou biológicos do paciente (BEZERRA, 2013).

Tendo em vista o conceito anteriormente apresentado de maneira breve, é importante ressaltar, em outros termos, que os transtornos mentais são tidos como as condições crônicas mais prevalentes em todo o mundo, afetando pessoas em todas as idades e classes sociais e constituindo um importante problema de saúde pública. A doença mental corresponde a respostas mal adaptadas a aspectos estressores, de origem interna e externa ao indivíduo, sendo exteriorizadas por meio de pensamentos, sentimentos e comportamentos contraditórios, interferindo diretamente na convivência social, na vida física e funcional. Em consequência das características dos transtornos mentais, essa condição determina intenso sofrimento para o indivíduo, bem como para a família e para o meio social (FERREIRA, 2015).

\subsection{TRATAMENTO EM SAÚDE MENTAL}

Historicamente a família foi excluída do tratamento voltado às pessoas com transtorno mental, tendo em vista que os hospitais psiquiátricos geralmente eram construídos distante das metrópoles, dificultando o aceso dos familiares. No Brasil, os chamados hospícios muitas vezes recebiam pessoas que sequer eram realmente portadoras de transtornos mentais, sendo forçadas a conviver com as pessoas doentes e em condições desumanas. Os pacientes eram esquecidos nesses locais, que abrigavam pessoas de todas as idades e em poucos casos recebiam alta hospitalar. As antigas formas de tratamento incluíam o eletrochoque, lobotomia e castigos físicos (BORBA et al., 2011). A partir da Reforma Psiquiátrica, surgiu um processo de reflexão, transformação que abrangeu os diferentes níveis assistenciais, culturais e políticos, estendendo-se por várias décadas no sentido de romper com o estigma do transtorno mental e assegurar o direito da cidadania aos portadores, para que possam conviver com a família, inseridos na mesma comunidade (BESSA; WAIDMAN, 2013). 
Os CAPS representam um importante passo no processo de conquista de direitos dos indivíduos portadores de transtornos mentais, visto que incorporam nas ações de saúde mental os princípios e garantias preconizados pelos direitos humanos. 0 atendimento nos CAPS visa alcançar a recuperação da saúde mental do indivíduo portador de transtornos, reinserindo o mesmo em sua comunidade, contexto social e ambiente familiar, posteriormente no trabalho e na sociedade de maneira plena, voltando a exercer atividades porventura interrompidas em razão da doença, trazendo benefícios e melhorias para o usuário de maneira gratuita e universalizada (SANTOS et al., 2015). Modernamente, o uso de medicamentos no tratamento de transtornos mentais passou a ser um recurso terapêutico aliado de outras práticas, e não uma medida coercitiva. Além disso, recursos como atendimentos psicológicos e outras medidas são incorporadas ao tratamento que é realizado nos CAPs e podem ser continuados pela própria família. Consequentemente, ocorre a melhoria da qualidade de vida, uma vez que o portador permanece, na maior parte do tempo, convivendo com sua família (FERREIRA, 2015).

\subsection{A FAMÍLIA NA CONVIVÊNCIA COM O PORTADOR DE TRANSTORNO MENTAL}

É importante destacar, a princípio, que praticamente em toda família existem tendências à saúde e à doença e, o fator mais relevante é a forma como a família enfrenta as situações de crise, o que depende da eficiência da comunicação e da afetividade entre os membros do grupo. 0 adoecimento de um membro da família, especialmente quando se trata de uma doença crônica, grave ou de caráter duradouro, é sempre um evento que provoca um importante abalo, uma brusca mudança na rotina. Nessa perspectiva, o transtorno mental é uma das enfermidades que mais provocam impacto na família, implicando em diversas dificuldades e, muitas vezes, culminando com o isolamento comunitário do indivíduo diagnosticado com o transtorno (BUDINI; CARDOSO, 2012).

No atual contexto de atenção à saúde mental, a família assume um lugar delimitado, participando de maneira fundamental do processo terapêutico do paciente. Contudo, é certo que isso gera uma grande sobrecarga, pois os familiares compartilham com os serviços de saúde a responsabilidade de promover o tratamento do ente querido, convivendo muitas vezes com situações de crise de difícil controle, e ainda com a imprevisibilidade do estado de saúde do portador de transtorno mental.

As famílias que convivem com o portador de transtorno mental experimentam o temor e a insegurança, sentimentos muitas vezes relacionados à possibilidade de surgirem comportamentos agressivos. Quanto maior é o comprometimento psiquiátrico, maior é a possibilidade de surgirem comportamentos de difícil controle, tais como os atos violentos. Contudo, esse comportamento muitas vezes é desencadeado por estímulos do meio, a exemplo dos conflitos gerados na própria família (CAMPANA; SOARES, 2015).

\section{METODOLOGIA}

O estudo foi do tipo pesquisa de campo, com abordagem qualiquantitativa e exploratória, por ser essencial para o alcance dos objetivos, tendo em vista que foi necessário entender a visão da família acerca da convivência com o portador de transtorno mental. Este artigo científico foi extraído de um projeto monográfico. Perspectiva de familiares na convivência com os portadores de transtornos mentais é o seu titulo original. E os demais fragmentos utilizados no artigo são dados considerados significante da monografia. 0 estudo foi realizado no Município de Ipaumirim, localizado na mesorregião do sul cearense. Na sede existem mais duas unidades. A pesquisa foi realizada nas Unidades Básicas de Saúde Sede I e Sede II, localizadas, respectivamente, no Centro da cidade e no bairro Fazendinha, zona urbana. Dessa forma, a amostra foi composta por 10 famílias que convivem com um portador de transtornos mentais e que estavam incluso na pesquisa e aceitaram participar. Como inclusão, famílias de portador de transtorno mental cadastradas nas UBS mencionadas, que aceitaram participar da pesquisa, sendo maiores de 18 anos e convivendo com o portador de transtorno mental há mais de 6 meses. A pesquisa foi desenvolvida em conformidade com as exigências formais definidas na resolução 466 de 2012, do Conselho Nacional de Saúde (CNS), a qual tem por objetivo regulamentar a pesquisa envolvendo seres humanos, com base na autonomia, não maleficência, beneficência, justiça e equidade, entre outros princípios (BRASIL, 2012). Após a aprovação do projeto pelo Comitê de Ética e Pesquisa (CEP) da Universidade Federal de Campina Grande, CAAE: 57738316.9.0000.5575, sobre número do parecer 1.667.329. 


\section{RESULTADOS E DISCUSSÃO}

Tabela 1 - Caracterização sociodemográfica dos participantes da pesquisa.

\begin{tabular}{|c|c|c|}
\hline $\begin{array}{l}\text { VARIÁVEIS } \\
\text { UBS }\end{array}$ & $\mathrm{F}$ & $\%$ \\
\hline Sede I & 7 & 70 \\
\hline Sede II & 3 & 30 \\
\hline \multicolumn{3}{|l|}{ FAIXA ETÁRIA } \\
\hline $30-40$ anos & 4 & 40 \\
\hline 41-51 anos & 1 & 10 \\
\hline 52-62 anos & 2 & 20 \\
\hline Acima de 62 anos & 3 & 30 \\
\hline \multicolumn{3}{|l|}{ GÊNERO } \\
\hline Feminino & 9 & 90 \\
\hline Masculino & 1 & 10 \\
\hline \multicolumn{3}{|l|}{ ESTADO CIVIL } \\
\hline Solteiro (a) & 5 & 50 \\
\hline Casado (a) & 3 & 30 \\
\hline Separado (a) & 1 & 10 \\
\hline Viúvo (a) & 1 & 10 \\
\hline \multicolumn{3}{|l|}{$\begin{array}{l}\text { № DE PESSOAS } \\
\text { RESIDENTES }\end{array}$} \\
\hline Até 2 pessoas & 1 & 10 \\
\hline Até 3 pessoas & 2 & 20 \\
\hline Mais de 3 pessoas & 7 & 70 \\
\hline \multicolumn{3}{|l|}{ RENDA SALARIAL } \\
\hline Um salário & 6 & 60 \\
\hline Dois salários & 2 & 20 \\
\hline Mais de dois salários & 2 & 20 \\
\hline TOTAL & 10 & 100 \\
\hline
\end{tabular}

Fonte: Dados da pesquisa, 2016.

Os dados revelam, portanto, que a maior parte das famílias é composta por vários membros, a maior parte dos quais possuem baixos índices de renda salarial, evidenciando a situação de dificuldades socioeconômicas enfrentadas por essa população. Em muitos casos, a composição das famílias visitadas se distanciou do modelo nuclear, com pais e filhos, apresentando também pessoas de diferentes graus de parentesco. Em um estudo realizado com 12 familiares responsáveis pelo cuidado de portadores de transtorno mental, contatadas através do cadastro em uma Unidade Básica de Saúde, demonstrou que a maior parte eram casados e com faixa etária de 60 a 69 anos (OLIVEIRA; CIRILO; COSTA, 2013).

Ademais, dois estudos realizados com familiares de portadores de transtorno mental também apontaram caracterização sociodemográfica semelhante, porém, objetivos de estudo ligeiramente diferentes. No primeiro, Nascimento et al. (2016) constataram a predominância do gênero feminino e a faixa etária entre 41 e 60 anos, em um estudo com 19 familiares entrevistados. Já no estudo conduzido por Estevam et al. (2011), participaram 12 famílias como informantes, sendo que em duas delas foram identificados mais de um portador de transtorno mental. Nesse estudo, prevaleceu o gênero masculino, sendo que alguns possuem ocupação e contribuem para a renda familiar.

Tendo em vista os resultados alcançados no presente estudo com relação à caracterização sociodemográfica dos participantes, especialmente quanto ao gênero e idade dos familiares, depreende-se que na maior parte dos casos as mulheres atuam como cuidadoras dos portadores de transtorno mental, sendo que, a faixa etária sempre varia por muitas vezes serem a mãe do paciente. 
Gráfico 1 - Dados relevantes à pesquisa de acordo com a perspectiva em conviver com o portador de transtorno mental (amostra $=10)$.

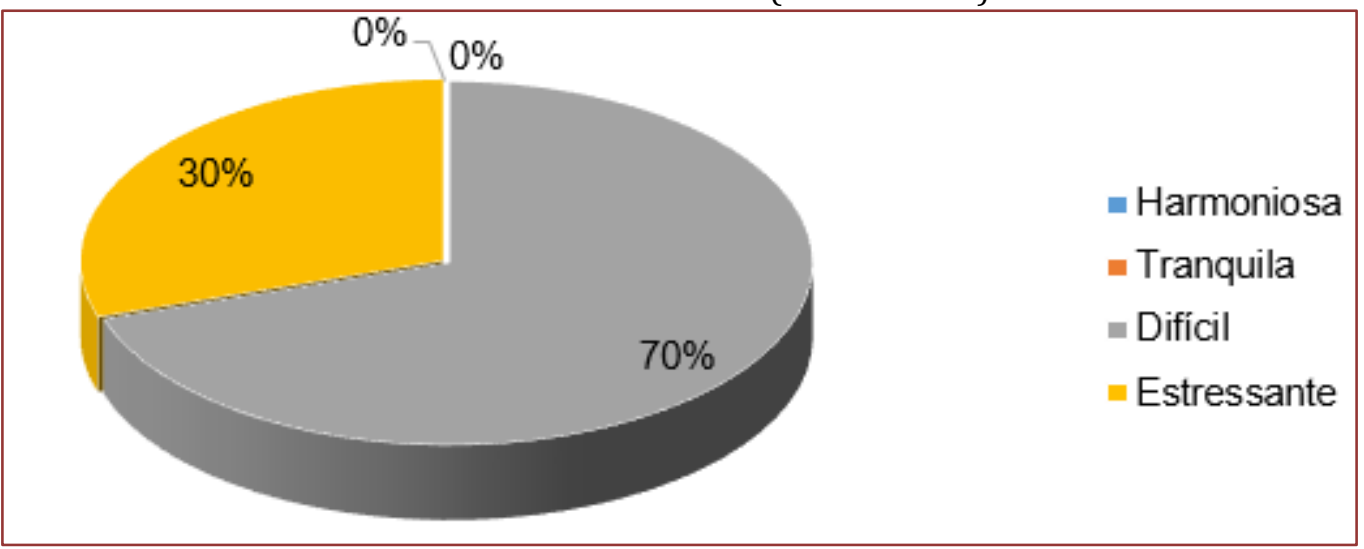

Fonte: Dados da pesquisa, 2016.

Dentre as categorias trabalhadas, alguns familiares relataram como essa dificuldade é vivenciada, conforme é possível perceber através de alguns relatos transcritos a seguir:

Para mim é sofrimento, ver ele nessa situação e não ter cura; e ele se transforma de uma hora para outra, a gente tem medo mas não pode fazer nada. (Familiar 6)

É ruim porque ela sai de casa as vezes ela não toma remédio. Fica agressiva tem dias que fica calma tem dia que ajuda nas atividades de casa. (Familiar 7)

É possível observar, de acordo com os relatos, que a convivência dos familiares com os portadores de transtorno mental geralmente é difícil, marcada por medo e insegurança, pela agressividade do portador e sofrimento de toda a família, fato que indica falhas na assistência recebida pela família com relação às formas de lidar com o paciente portador de transtorno metal. A instabilidade do paciente também é apontada como importante motivo de sofrimento, uma vez que a mudança de humor e comportamento é repentina e pode representar risco para familiares ou para outras pessoas que, por desconhecerem características da doença, muitas vezes chegam até mesmo a não compreender as dificuldades vivenciadas.

Segundo Borba et al. (2011), o cuidado à pessoa portadora de transtorno mental sempre representa um desafio para a família, pois envolve sentimentos relacionados à vivencia diária com a possibilidade de crises e imprevistos, além dos próprios preconceitos da família com relação à doença. Dessa forma é importante que os familiares sejam capazes de perceber o ser humano por trás da doença, suas capacidades e possibilidades. Apesar do desgaste que ocasiona, a melhor forma de cuidar do portador de transtorno mental é em meio à sua família.

As dificuldades no cuidado aos portadores de transtorno mental são evidenciadas através das preocupações, impaciência, incômodos ou sentimentos de medo pelo comportamento do portador. A sobrecarga atinge toda a família, mas, especialmente, o membro que se responsabiliza por cuidar do paciente, administrar medicamentos e desenvolver uma vivência melhor. Nesse sentido, observa-se que na maior parte dos casos, as dificuldades enfrentadas pelos familiares repercutem nas relações desenvolvidas com o portador de transtorno mental, gerando condutas que nem sempre é ideal para o tratamento, como isolamento do paciente no ambiente doméstico, medo de se aproximar e conviver com o familiar e até mesmo, a internação psiquiátrica. 
Gráfico 2 - Dados relevantes à pesquisa de acordo com as dificuldades encontradas para conviver com o portador de transtorno mental (amostra $=10$ ).

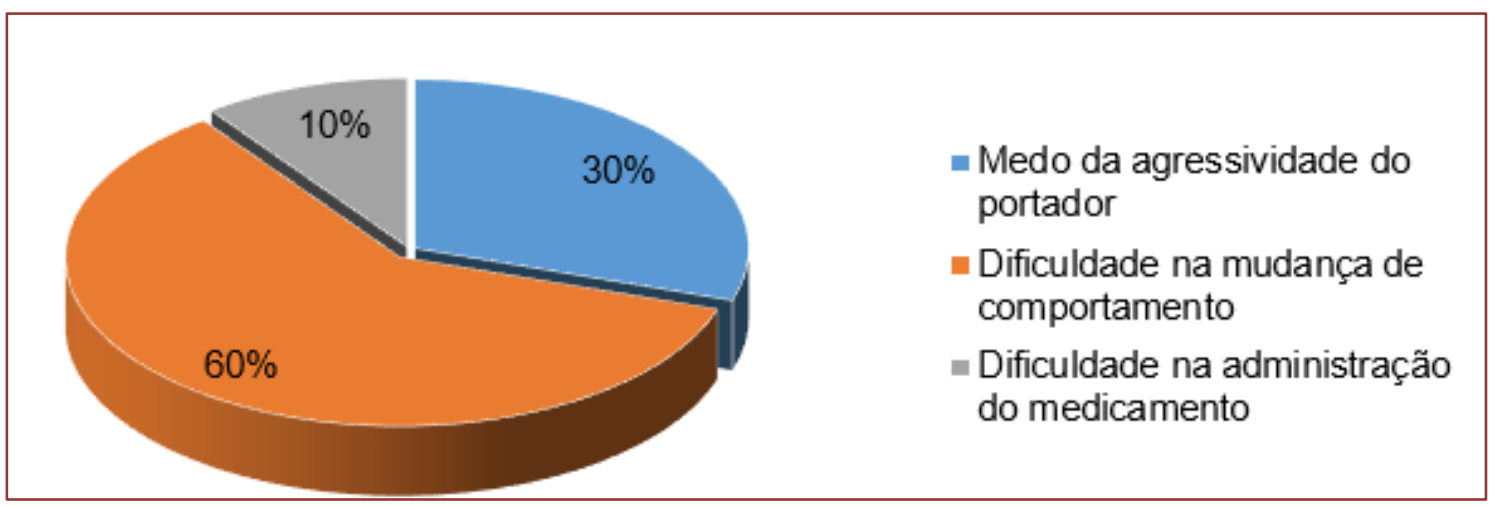

Fonte: Dados da pesquisa, 2016.

Os relatos dos entrevistados estão transcritos a seguir:

Porque às vezes ela fica agressiva comigo chama nome feio, já chegou a jogar uma concha em mim, cortou e saiu sangue. (Familiar 8)

São muitas dificuldades, até porque quando ele tá em crise ele fica muito agressivo, tem que tá supervisionando e não durmo direito porque tem que tá atendo a ele. (Familiar 10)

Observou-se que para alguns familiares o cuidar do portador de transtorno mental é algo que traz intenso sofrimento, uma tarefa sem fim, que parece se complicar mais a cada dia. A convivência geralmente traumática, marcada pela iminência de uma crise ou uma mudança de comportamento abrupta. As famílias acabam colocando a doença como centro de suas vidas, pois dificilmente conseguem estabelecer outras relações.

De acordo com Campana e Soares (2015), é necessário cuidar não apenas do portador de transtorno mental, mas, também, da família, tendo em vista à intensa sobrecarga e dificuldades que precisa atravessar. 0 cuidado voltado às famílias e, especialmente, aos familiares que cuidam do portador de transtornos mentais, deve permear as principais dificuldades do cotidiano e proporcionar acolhimento aos cuidadores, para que não venham também a adoecer de alguma forma.

Nesse aspecto os relatos dos participantes evidenciam que a convivência com o portador de transtorno mental traz preocupações constantes com relação ao doente, insegurança com o futuro e, principalmente, quando o familiar possui idade avançada e não possuiu conhecimento da doença. É importante observar que a condição de familiar não preparado para a situação de convivência, pode trazer um forte impacto para a qualidade de vida, pois existe uma severa limitação da rotina em função dos cuidados ao portador.

Nesse sentido, ressalta-se que o cuidado da família com relação ao portador de transtorno mental necessita do apoio dos profissionais de saúde, uma vez que a Reforma Psiquiátrica toma como prioridade a cidadania, o acesso aos serviços e a reabilitação psicossocial do portador. Sabe-se da importância da participação da família no tratamento do sujeito portador de transtorno mental, mas, ao mesmo tempo, fica claro que muitas famílias dependem de assistência e orientação para poderem fornecer aos portadores os cuidados necessários. 
Gráfico 3 - Dados relevantes à pesquisa de acordo com a forma como a família lida com os momentos de crises psiquiátrica do portador (amostra $=10$ ).

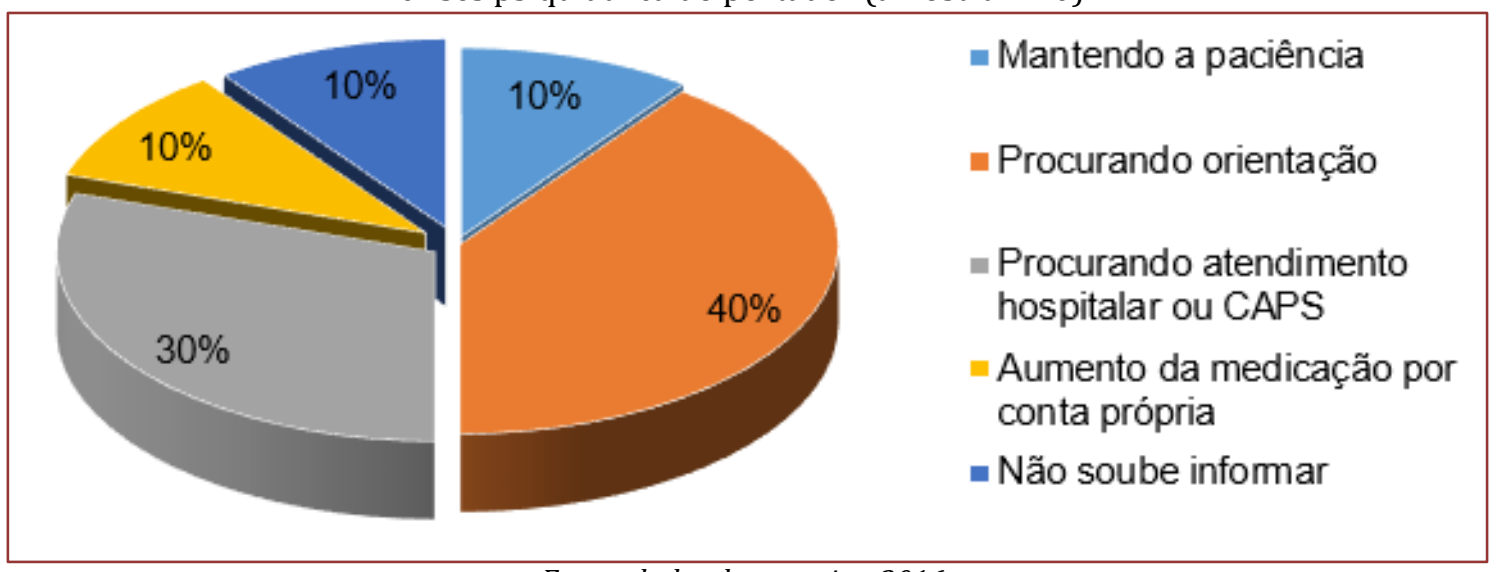

Fonte: dados da pesquisa, 2016.

Os relatos transcritos a seguir evidenciam que:

É uma situação difícil e constrangedora, ele passa por mais tempo em crise do que melhor, então nunca se sabe o dia de amanhã, então ele precisa estar preso por trás de uma grade porque não tem condições de ficar solto. (Familiar 1)

É difícil de lidar porque ele fica muito nervoso, então a gente leva ele para o CAPS e eles mudam o remédio e a gente volta. (Familiar 9)

Segundo expressa Nascimento et al. (2016), lidar com situações de crise é sempre uma tarefa complexa, pois exige intensa participação da família e de profissionais de saúde. Com relação às respostas dos participantes da pesquisa, a maior parte afirmou buscar orientação, mas também foi mencionado o aumento da medicação por conta própria, como forma de controlar a crise, independente de orientação nesse sentido. Isso demonstra que há uma necessidade de acompanhamento, supervisão às famílias com portadores de transtorno mental, auxiliando no cuidado e orientando a respeito do manejo de crises.

Ainda existe uma tendência de manutenção do modelo biomédico, priorizando o uso de medicamentos e hospitalização. Dessa forma, os familiares e os portadores de transtornos mentais são ainda mais prejudicados pela ausência de uma rede específica em saúde no município, tendo que se deslocarem para outros municípios. Necessitando de uma assistência que poderia potencializar a capacidade de cuidado da família.

\section{CONSIDERAÇÕES FINAIS}

No estudo, observamos que a perspectiva dos familiares com relação ao portador de transtorno mental é principalmente de preocupação, medo e sofrimento, devido às mudanças de comportamento, à imprevisibilidade do paciente e ao futuro incerto. Nesse sentido, a assistência dos profissionais de saúde aos familiares é imprescindível, pois contribui na relação que se faz necessária entre os familiares e portadores de transtornos mentais para que seja possível compreender as manifestações da doença. De um modo geral, foi possível perceber que a relação entre os familiares e o portador de transtorno mental se dá principalmente em função da imprevisibilidade do paciente, a ausência de afeto e a constante preocupação com a possibilidade de crises inesperadas. A realização da presente pesquisa envolveu algumas dificuldades, haja vista que não foi possível contatar parte das famílias na primeira visita, sendo necessário localizar o Agente Comunitário de Saúde responsável pelas respectivas áreas para facilitar a entrevista. Além disso, o pouco tempo disponível para a coleta de dados tornou necessário acelerar diversas etapas do estudo. Recomenda-se a realização de estudos que possam contribuir para incrementar a literatura específica, elucidando as diferentes formas como se dá o relacionamento e a perspectiva dos familiares e cuidadores com relação ao paciente portador de transtorno mental. 


\section{REFERÊNCIAS}

[1] Bezerra, I. C. Uso de psicofármacos na atenção psicossocial: sujeito, autonomia e corresponsabilização. Dissertação (Mestrado em Saúde Coletiva) - Universidade Estadual do Ceará, Fortaleza, 2013.

[2] Bessa, J. B.; Waidman, M. A. P. Família da pessoa com transtorno mental e suas necessidades na assistência psiquiátrica. Texto Contexto Enfermagem, Florianópolis, v. 22, n. 1, p. 61-70, jan./mar., 2013.

[3] Borba, L. O.; PAES, M. R.; GUIMARÃES, A. N.; LABRONICI, L. M.; MAFTUM, M. A. A família e o portador de transtorno mental: dinâmica e sua relação familiar. Revista Escola de Enfermagem USP, v. 45, n. 2, p. 442-449, 2011.

[4] Budini, C. R.; Cardoso, C. Concepções de doença mental por familiares de pacientes com diagnóstico de esquizofrenia. Perspectiva, Erechim, v. 36, n. 136, p. 143-154, dezembro, 2012.

[5] Campana, M. C.; SOARES, M. H. Familiares de pessoas com esquizofrenia: sentimentos e atitudes frente ao comportamento agressivo. Cogitare Enfermagem, v. 20, n. 2, p. 338-344, abr./jun., 2015.

[6] Fernandes, M. A.; MAIA, M. A. B.; Meireles, P. C. J.; Sousa, L. E. N. Reforma psiquiátrica: percepção da família do portador de transtorno mental. Revista Interdisciplinar Uninovafapi, Teresina, v. 5, n. 3, p. 21-25, jul./ago./set., 2012.

[7] Ferreira, A. C. Z. A complexa vivência do portador de transtorno mental no uso de psicofármacos. Dissertação (Mestrado em Enfermagem) - Universidade Federal do Paraná, Curitiba, 2015.

[8] Nascimento, K. C.; Kolhs, M.; Mella, S.; Berra, E.; Olschowsky, A.; Guimarães, A. N. O desafio familiar no cuidado às pessoas acometidas por transtorno mental. Revista Enfermagem UFPE On Line, Recife, v. 10, n. 3, p. 940948, mar., 2016.

[9] Oliveira, L. V.; Cirilo, L. S.; Costa, G. M. C. O cuidar do portador de transtorno mental: significado para a família. Revista Baiana de Saúde Pública, v. 37, n. 1, p. 164-178, jan./mar., 2013.

[10] Santos, R. A. S.; Barbosa, K. K. S.; Lellis, M. F.; Sampaio, S. F.; Porto, E.; Albuquerque, R. S. Dificuldades enfrentadas pela família na convivência com o portador de transtorno mental. SANARE, v. 14, Supl. 1, p. $20,2015$. 


\section{Capítulo 7}

As TIC's como proposta de inovação do conhecimento na agricultura familiar do Semiárido Potiguar Brasileiro

Zildenice Matias Guedes Maia

Christiane Fernandes dos Santos

Danielle Simone da Silva Casillo

Leonardo Augusto Casillo

Resumo: Atualmente, observar-se um fortalecimento da relação entre o poder público e sociedade civil organizada, no que diz respeito à implantação de políticas públicas para o contexto rural. Considerando essa realidade no contexto do semiárido potiguar brasileiro, a Universidade Federal Rural do Semi-Árido (UFERSA) vem implantando a cultura digital, através do Programa "Estruturação de Telecentros e Casas Digitais e Formação de Multiplicadores em Comunidades Rurais de Municípios do Semiárido Potiguar - Semiárido Digital", em diferentes municípios do Estado do Rio Grande do Norte: Angicos, Apodi, Caraúbas, Fernando Pedroza, Janduís e Mossoró. A finalidade do Programa é desenvolver a cultura digital no âmbito de comunidades rurais e urbanas desses municípios por meio da reestruturação dos Telecentros e Casas Digitais disponíveis nas comunidades. Também, propõe a oferta de cursos básicos de informática, cursos à distância de formação, além de formar multiplicadores do conhecimento. Dessa maneira, o artigo em questão, tem como objetivo apresentar os principais resultados alcançados através das etapas já realizadas pelo "Semiárido Digital". Ações como manutenção e instalação dos equipamentos de informática, softwares e internet, já foram realizadas nos municípios de Janduís (4 telecentros), Mossoró (1), Apodi (3), Fernando Pedroza (2) e Angicos (2). Os cursos de Informática Básica e o de Introdução a Educação à Distância e ao ambiente Moodle, já foram realizados nos telecentros presentes no município de Janduís. Dessa forma, um total de 46 alunos foram contemplados com o Curso de Informática e o de Introdução a Ead e ao Ambiente Moodle, sendo 18 concluintes da comunidade de Setubal, 11 de Pacuti e 16 da Associação Santa Teresinha. Estão em curso as aulas de informática no município de Angicos e Fernando Pedroza, Mossoró (Maísa) e também em Janduís, capacitando novas pessoas. As diferentes estratégias de inovações permitidas pelas TICs foram pensadas mediante o contexto e necessidades do local. Desse modo, surgem como possibilidade de fortalecer a vivência das pessoas na própria comunidade, seja através da formação presencial e/ou à distância, proporcionando a possibilidade de otimização das suas atividades produtivas e da valorização do local, através da inclusão digital e social.

Palavras-chave: TIC's, Semiárido Digital, Agricultura familiar. 


\section{Introdução}

O semiárido brasileiro abrange um total de 1.133 municípios. Apresenta uma área de 969.589,4 $\mathrm{Km}^{2}$, concentrando uma população de mais de 21 milhões de habitantes, que corresponde, em média, a $11 \%$ da população brasileira (SILVA, 2006). Essa região, apesar de apresentar alguns avanços sociais e econômicos nas últimas décadas, revela um baixo dinamismo econômico e social, além de uma expressiva degradação ambiental. A persistência das graves problemáticas presentes nessa região pode estar associada às políticas públicas que vinham sendo desenvolvidas, sem considerar as especificidades e características locais, bem como a participação social.

Nesse sentido, é possível que a ausência ou ínfima participação da sociedade foi decorrente do cenário de centralização e das relações assimétricas presentes no contexto da sociedade civil. Contudo, é a partir de 1990 que a sociedade reivindica de forma contundente o reconhecimento do seu protagonismo. Müller (2007, p. 13), em seu estudo sobre a construção de políticas públicas, aponta que a partir desse momento, o papel do Estado tem passado por modificações no que concerne a sua atuação de agente centralizador e interventor. Considerando tal fato, revela que "o Estado sozinho é incapaz de garantir o bem-estar da Sociedade" e que "a participação dos beneficiários no processo de construção, implantação e gestão das políticas públicas potencializa os benefícios trazidos das políticas".

A partir de então, os movimentos pela participação e descentralização nas políticas públicas tornaramse crescentes, assim como aquelas de maior reconhecimento da importância da agricultura familiar. De acordo com Leff (2006) as políticas públicas voltadas para medidas de cooperação entre o mercado, o Estado e a organização produtiva das comunidades, surgem como forma de incorporar critérios de sustentabilidade às políticas de desenvolvimento rural. Destarte, entende-se que o processo de construção das políticas de desenvolvimento rural no Brasil, desde a redemocratização, deu-se em momentos contínuos e não estanques de fortalecimento da agricultura familiar, marcados por lutas sociais, por uma agenda de reivindicação por garantia de direitos - como o acesso a terra e ao território, à cidadania e ao desenvolvimento econômico - e por avanços na dinâmica de formulação e atuação do Poder Público (BRASIL, 2013).

Desse modo, a democratização do país propiciou uma aproximação entre instâncias do Estado e organizações da sociedade civil, além do maior envolvimento dessas últimas na execução de alguns programas. Sendo necessário salientar que nem sempre essas políticas se tornam uma proposta exitosa e promotora da sustentabilidade. Observa-se que as políticas públicas voltadas para o semiárido brasileiro passaram por modificações significativas nas últimas décadas, ultrapassando o seu alcance no que se refere á disponibilidade de políticas meramente assistencialistas e, portanto, insustentável.

Atualmente, é possível observar um fortalecimento da relação entre o poder público (nas diferentes esferas) e da sociedade civil organizada, no que concerne a implantação de políticas públicas, e adotando um posicionamento mais crítico sobre o desenvolvimento onde os aspectos econômicos, sociais, políticos, tecnológicos, culturais e ambientais devem ser analisados de maneira inter-relacionada e em igual grau de relevância. Percebe-se, ainda, uma transformação no rural brasileiro, instigando a compreendê-lo como espaço de produção e reprodução social de sua população. Dessa maneira, o rural tem se constituído, além de loco de produção agrícola, como loco de reprodução social, de vida e trabalho (WANDERLEY, 2009). Condição que atualmente passava despercebida pela maioria dos estudiosos, essas novas configurações observadas no meio rural, têm sido fortalecidas pela intervenção de diferentes políticas públicas destinadas a esse espaço, ultrapassando o seu alcance quanto à disponibilidade de crédito, estabilização de preços e assistência técnica, incorporando outras políticas que promovam a sustentabilidade social, cultural e tecnológica, capazes de promover o protagonismo do homem do campo.

Considerando a importância do cenário de definição de políticas voltadas para a realidade da sociedade brasileira, e mais especificamente a região do semiárido potiguar, destaca-se o Programa Territórios Digitais e o Programa Telecentros Comunitários, atraindo organizações que atuam na gestão e desenvolvimento de políticas sustentáveis. Assim, buscam envolver a sociedade civil na construção de processos participativos para proposição, realização, avaliação e controle social das políticas públicas, na perspectiva da sustentabilidade.

De acordo com as informações obtidas no site oficial do Ministério do Desenvolvimento Agrário - MDA, em 2008 foi criado o projeto Territórios Digitais, com o objetivo de "oferecer gratuitamente o acesso à informática e internet para populações rurais, por meio da implantação de Casas Digitais". Estas deverão ser escolhidas pela própria comunidade, e tem como finalidade a garantia de um ponto de acesso comunitário gratuito para os agricultores e agricultoras familiares. "A ideia central é garantir ao público-alvo a universalização do acesso às tecnologias de informação e comunicação e à rede mundial de 
computadores."

Já os Telecentros Comunitários, de acordo com o Ministério das Comunicações, são espaços públicos sem fins lucrativos, que dispõem de computadores conectados à internet, disponíveis para diversos usos. 0 Programa tem por objetivo promover o desenvolvimento social e econômico das comunidades atendidas, visando reduzir a exclusão social, e criando oportunidades de inclusão digital aos cidadãos. Os telecentros comunitários visam oferecer cursos e atividades, além de funcionarem como espaço de integração, cultura e lazer. Os beneficiários devem contar com assistência de monitores qualificados, que por sua vez devem ser atores locais. Segundo informações desse mesmo Ministério, atualmente, existem 7.755 telecentros em todo o Brasil. Os mesmos foram instalados por meio de uma parceria entre ministérios, prefeituras e entidades, que são responsáveis pela manutenção desses espaços.

As Universidades brasileiras, com a estratégia de ir ao encontro dessa demanda voltada para o contexto rural, vêm desenvolvendo ações de extensão que propiciam, de fato, a inclusão dos agricultores familiares no mundo digital, como é o caso do Programa "Estruturação de Telecentros e Casas Digitais e Formação de Multiplicadores em Comunidades Rurais de Municípios do Semiárido Potiguar Semiárido Digital", realizado pela Universidade Federal Rural do Semi-Árido (UFERSA) em diferentes municípios do Estado do Rio Grande do Norte: Angicos, Apodi, Caraúbas, Fernando Pedroza, Janduís e Mossoró. 0 objetivo do Programa é desenvolver a cultura digital no âmbito das comunidades rurais e urbanas desses municípios de por meio da reestruturação física e lógica dos Telecentros e Casas Digitais disponíveis nas comunidades. Também, propõe a oferta de cursos básicos de informática, cursos à distância de formação profissional e realização de mostras e eventos culturais, além de formar multiplicadores do conhecimento nas próprias comunidades.

Dessa maneira, o artigo em questão, apresenta os resultados das etapas já realizadas pelo "Semiárido Digital" que consistiram no diagnóstico socioeconômico, estruturação dos telecentros e realização de cursos de informática básica (na modalidade presencial) e curso introdutório de educação à distância e ao ambiente moodle, na modalidade à distância.

\section{METODOLOGIA}

0 desenho metodológico do presente artigo corresponde àquele delineado para a efetivação das ações do Programa Semiárido Digital uma vez que se trata da apresentação dos resultados das diferentes etapas. Entretanto, cabe enfatizar que o mesmo ainda se encontra em fase de continuidade, mas que diversas ações já foram realizadas até o presente momento.

As comunidades beneficiadas pelo Programa Territórios Digitais do Ministério de Desenvolvimento Agrário (MDA) e pelos Telecentros Comunitários implantados pelo Ministério das Comunicações foram, em sua maior parte, contempladas com equipamentos que propiciassem o acesso à informática e internet. No entanto, a atuação destes programas limitou-se à doação dos equipamentos como computadores e impressoras. Em algumas comunidades, tais equipamentos permaneceram guardados por meses por não haverem pessoas com conhecimento técnico suficiente para a instalação dos computadores e para o acesso à internet. Por se tratarem de aparelhos eletrônicos, a sua não-utilização por um longo período ocasiona um mal funcionamento, podendo levar até mesmo a inutilização do equipamento.

Tendo conhecimento de tal fato, a primeira providência tomada por parte da equipe responsável pelo programa Semiárido Digital foi realizar uma visita técnica em cada uma das comunidades selecionadas, a fim de fazer um diagnóstico sobre o estado físico de cada um dos Telecentros e Casas Digitais. Os equipamentos que foram encontrados ainda lacrados foram ligados, formatados, revisados e tiveram os principais softwares gratuitos - como o sistema operacional e o pacote de aplicativos de escritório - instalados. Também foram realizados os serviços de instalação da impressora e equipamentos para o acesso à internet. Para os Telecentros que já estavam utilizando os computadores, todos foram revisados, formatados e os softwares instalados. Os equipamentos que apresentaram problemas de funcionamento foram reparados, substituídos, ou foi indicado para as associações responsáveis quais as ações necessárias para sua adequação. Quanto ao acesso à internet, nas visitas realizadas foram pensadas e aplicadas as soluções para a viabilização dos provedores e sinais de internet necessários, bem como a instalação da rede lógica para propiciar tal operação.

Nesta etapa também foi analisado o ambiente no qual os computadores foram instalados. Em parceria com as Associações e Comunidades, foram analisadas questões relativas ao calor, ergonomia, segurança e economia quanto ao consumo de energia e sugeridas as modificações necessárias para o bem-estar dos participantes. 
A partir do momento em que os equipamentos de informática estavam em condições de uso, a próxima etapa do Programa foi a realização de um diagnóstico socioeconômico em cada comunidade, buscando fazer uma análise das características das pessoas interessadas em se tornarem alunos dos cursos oferecidos e, também verificar a os dias e horários de maior interesse e disponibilidade do público-alvo. Para a realização dessa análise, a abordagem dos habitantes se deu por meio da aplicação de questionários, os quais, voluntariamente, os moradores se dispuseram a responder.

Os questionários elencaram perguntas básicas de identificação e questionamentos relacionados aos conhecimentos e interesses na área de informática e conhecimentos voltados para a área rural. Esta etapa visa oferecer para cada comunidade os cursos online que sejam de maior interesse ou que beneficiem mais a comunidade quanto aos aspectos econômicos e laborais. Até o presente momento, os cursos online disponíveis são Introdução a Educação à Distância e ao Ambiente Moodle, Agricultura familiar, Agroecologia, Empreendedorismo rural e meio ambiente.

É importante ressaltar que esta etapa não possui um caráter eliminatório, sendo o único fator limitante a necessidade de o aluno saber ler e escrever, visto que este conhecimento é necessário para a realização das atividades dos cursos oferecidos. 0 público-alvo inicialmente definido pela equipe do programa era composto por agricultores, donas-de-casa e estudantes, mas devido à alta procura em algumas comunidades, não foi imposto limite de idade ou profissão, estando aberto a todos os interessados, com restrições apenas pela quantidade de computadores disponíveis nas turmas oferecidas.

Após a seleção de alunos, a etapa seguinte refere-se ao curso presencial de informática básica. Este curso tem por objetivos a inclusão digital de pessoas que até então não haviam tido a oportunidade de utilizarem equipamentos de informática; a atualização de pessoas que já fizeram cursos de informática, mas que, em virtude do contínuo avanço tecnológico, este conhecimento já está defasado ou mesmo tornou-se obsoleto; e, preparar o aluno para conhecer o ambiente de ensino à distância utilizado pela equipe do programa, e esteja apto a participar dos cursos on-line. O curso presencial de informática básica, além de apresentar o básico de hardware e software, terá como foco auxiliar o aluno em atividades necessárias para o seu cotidiano ou para o mercado de trabalho, como, por exemplo, preparar corretamente um currículo, criar uma planilha financeira, preparar uma apresentação de trabalho, ou realizar buscas mais confiáveis na internet.

Para cada curso realizado, seja presencial ou à distância, desde que o aluno atinja um limite de cargahorária e desempenho satisfatório das atividades, será disponibilizado certificado, o que irá auxiliar o aluno no mercado de trabalho, que atualmente exige conhecimentos em informática como requisito obrigatório para diversas atividades.

Desta feita, o Programa vem proporcionando às comunidades rurais, e também urbanas, uma nova perspectiva de desenvolvimento local onde o acesso ao computador e a internet se constituem como ferramentas capazes de promover inovações nos aspectos organizacionais, produtivos, de cultura e lazer, conforme pode ser evidenciados nos resultados, ora, obtidos.

\section{RESULTADOS E DISCUSSÃO}

\subsection{O PROGRAMA SEMIÁRIDO DIGITAL E AS TECNOLOGIAS DA INFORMAÇÃO E COMUNICAÇÃO NO SEMIÁRIDO POTIGUAR BRASILEIRO}

O Programa Semiárido Digital tem como principal finalidade difundir a cultura digital em diferentes municípios do interior do Rio Grande do Norte, criando oportunidades de inclusão social, por meio do acesso digital em comunidades que se encontram à margem das Tecnologias da Informação (TI). De acordo com Silva (2003, p.15-16) a TI surgiu como ferramenta de apoio à gestão das empresas a partir da década de 90, sendo entendida como uma ferramenta de "integração das operações da empresa e entre empresas, com ganhos de agilidade e redução nos custos operacionais". E, compreende: "o conjunto convergente de tecnologias em microeletrônica, computação, telecomunicações/radiodifusão, e optoeletrônica, incluindo também a engenharia genética" (Castells, 2000, p. 49).

Essa ação de extensão se caracteriza pelo fato de envolver tanto o poder público como organização comunitária, deixando explícita a participação social durante todo o processo. Nesse sentido, Afirma Weber (2002, p. 130): 
[...] as opções tecnológicas não se reduzem à dimensão dos investimentos ou à dos ganhos de eficácia. Elas modificam os usos que fazemos dos recursos e, em consequência disso, os modos de apropriação, vale dizer, as representações e os processos de tomada de decisão.

O Semiárido Digital ultrapassa a ideia de investimentos em estrutura física tecnológica à medida que incorpora em sua proposta, e faz acontecer, cursos de formação cuja proposta de conteúdo foi construída através de um processo de tomada de decisão pautado no diálogo entre Universidade e o público alvo. Essa dialogicidade interfere, positivamente, na forma que os indivíduos se apropriam dessas tecnologias, pois a partir de então já passam a conhecê-la melhor.

o Programa já iniciou suas atividades de estruturação física e lógica nos Telecentros e Casas Digitais, bem como a realização de cursos presenciais nos municípios de Janduís, nas comunidades rurais de Setúbal, Pacuti e Associação Santa Terezinha (zona urbana da cidade de Janduís), Angicos, Fernando Pedroza e em Mossoró, na comunidade Maísa. As comunidades de Janduís, por terem sido escolhidas como projetopiloto, são as que estão com as atividades mais adiantadas, pois já em execução os cursos à distância. 0 município de Apodi é o que está em maior dificuldade, devido à estrutura precária dos espaços físicos e grau de deterioração dos equipamentos de informática. 0 município de Caraúbas é o único município que ainda não iniciou suas atividades.

Acosta-Hoyos (1985) ressalta que a tecnologia consiste em parte integrante da cultura, e por isso está presente na sociedade. E corrobora Rocha Loureiro (2009, p. 99) "as tecnologias não são mais apenas dispositivos imutáveis, mas cada vez mais dependem dos arranjos sociais entre as partes interessadas". Nesse contexto, Leff (2006) sinaliza que como o Estado tem um histórico de intervenção baseado em medidas dissociadas das realidades locais das comunidades rurais, só uma ação baseada na redefinição do seu papel combinada com a participação da comunidade local é que poderá levar ao êxito do desenvolvimento social.

Em todas as comunidades visitadas, foi realizada uma aula inaugural, com a presença dos coordenadores do Programa, os bolsistas responsáveis pelas aulas de informática, os bolsistas responsáveis pela elaboração do material didático dos cursos à distância, demais colaboradores e autoridades convidadas. Foram realizados termos de compromisso com as prefeituras locais para formalização das atividades a serem realizadas, e as Associações e comunidades foram previamente visitadas para maiores explicações e questionamentos, bem como para combinar o melhor dia e horário para a aplicação dos questionários. Dessa maneira, pode-se inferir que o avanço das etapas do Programa em alguns municípios deve-se a contrapartida oferecida pelo poder público local e, também, pelo poder de mobilização da sociedade civil organizada, pois o envolvimento desses agentes para o êxito do Programa reflete uma situação de intervenção que vai ao encontro da realidade e interesse local.

A etapa do questionário socioeconômico foi realizada em todas as comunidades, com exceção de Caraúbas. Os gráficos a seguir, representados pela Figura 1, são resultantes da compilação das 421 respostas obtidas (Angicos - 111; 117 Apodi - 117; Fernando Pedroza - 88; Janduís - 20 e em Mossoró - 85) no decorrer do diagnóstico, até então realizado.

Pode-se perceber que $44 \%$ do público alvo interessado nas ações do programa encontra-se em média na faixa de 15 a 20 anos e $34 \%$, acima de 20 . Sendo que dentro destes, $58 \%$ correspondem ao gênero feminino; quando relacionado às pessoas que possuem curso de informática, apenas 34\% responderam já ter realizado curso nessa área. Por outro lado, $78 \%$ destes informaram ter acesso diário a internet; Os cursos mais requisitados foram: agricultura familiar (37\%), empreendedorismo rural (32\%), meio ambiente (18\%), administração de negócios (7\%) e agroecologia (6\%). 0 interesse representado pelas temáticas afirmadas serviu de base para o planejamento dos cursos na modalidade à distância, pois o propósito do Programa é aprimorar o conhecimento que é pertinente para o fortalecimento da vivência e prática das comunidades, e que não seja antagônico com a cultura do local.

Assim, apreende-se que o desenvolvimento de políticas para comunidades do semiárido deve ao mesmo tempo em que situar o ser humano no seu entorno e despertar nele a consciência da materialidade social, trazer o dinamismo proveniente da cultura local, uma vez que esta é a portadora das representações e do imaginário possível do uso e das decisões dos recursos sociais e naturais. Assim tratar a concepção de desenvolvimento de uma comunidade deve ter o modo de vida local e o progresso das comunidades como referências matriciais (SCHALLENBERGER, 2003). Portanto, não se deve impor um conhecimento ou vivências externas, mas sim fortalecer práticas e valores locais de modo a que as ferramentas inseridas sejam utilizadas para construir e fortalecer a comunidade e não destruir seus valores. 
Figura 1 - Compilação dos dados do questionário socioeconômico

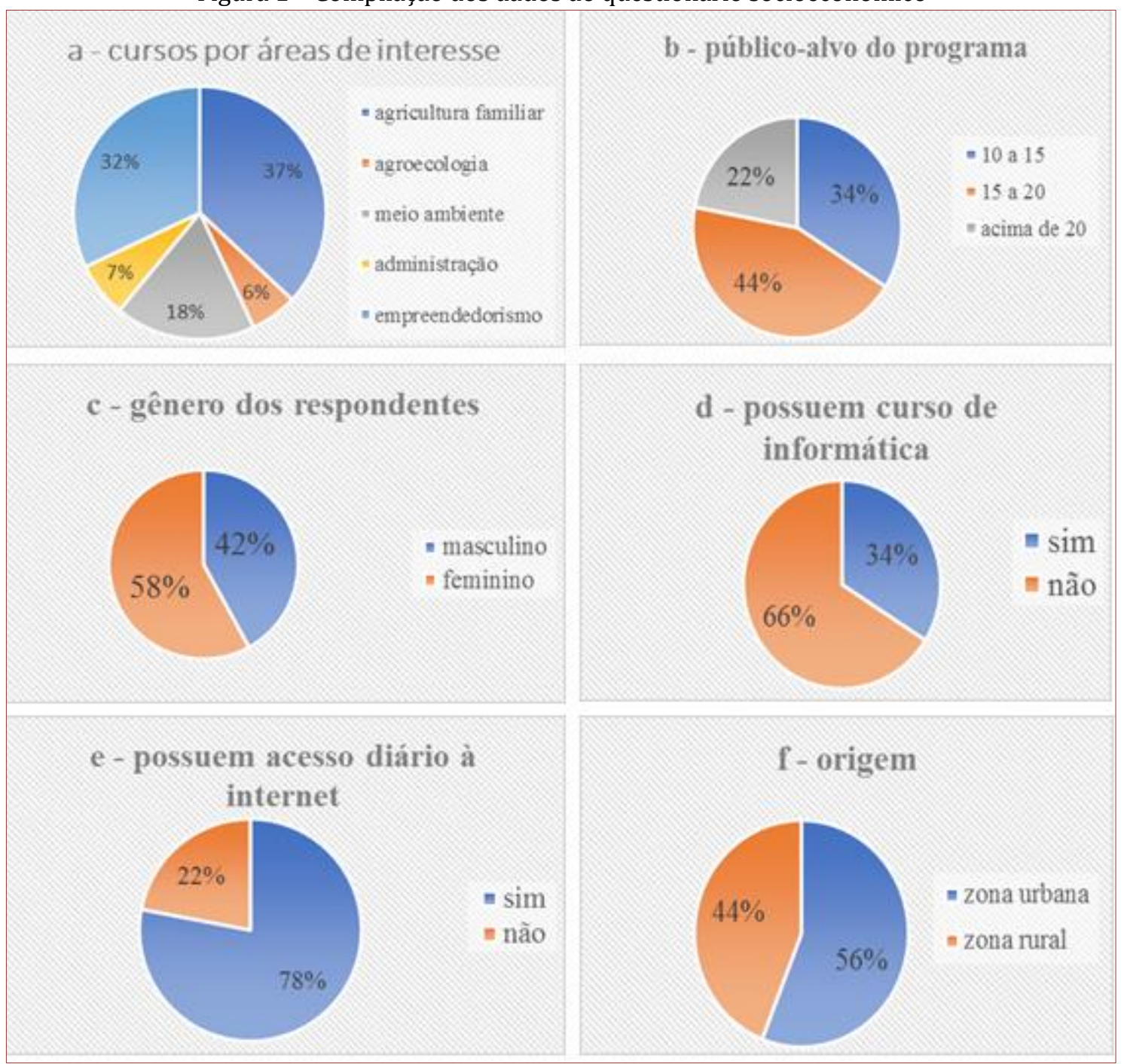

Fonte: Semiárido Digital, 2017.

Os dados mostram que os moradores das comunidades que preencheram o questionário são, em sua maioria, mulheres, adolescentes e jovens que vivem na zona urbana do município, embora tenha ocorrido interesse de moradores da zona rural. A maioria dos entrevistados já possuem um certo conhecimento em informática, e acessam constantemente a internet, em sua maior parte redes sociais, principalmente por meio de telefones celulares, mas que se interessaram pelo curso em razão de um melhor aprendizado das ferramentas e pela emissão de certificado. Os cursos online pretendidos.

Ações como manutenção e instalação dos equipamentos de informática, softwares e internet, já foram realizadas nos municípios de Janduís (4 telecentros), Mossoró (1), Apodi (3), Fernando Pedroza (2) e Angicos (2). Os cursos de Informática Básica e o de Introdução a Educação à Distância e ao ambiente Moodle, já foram realizados nos telecentros das comunidades de Pacutí e Setúbal. Ressaltando-se que, inicialmente, a proposta era que os cursos fossem ofertados apenas nestas duas comunidades, entretanto devido à construção de novas parcerias, foram possíveis a instalação de mais dois telecentros na zona urbana. Dessa forma, um total de 46 alunos foram contemplados com o Curso Básico de Informática e o de Introdução à Ead e ao Ambiente Moodle ministrados pelo programa, sendo 18 concluintes nas comunidades de Setubal, 11 em Pacuti e 16 na Associação Santa Teresinha, no município de Janduís. Estão em curso as aulas de informática no município de Angicos e Fernando Pedroza, Mossoró (Maísa) e também em Janduís, capacitando novas pessoas. A próxima etapa então consistirá na aplicação do curso de "Agricultura Familiar". 
A Figura 2 apresenta três momentos do Programa em uma das comunidades atendidas: momento em que o laboratório de informática foi entregue totalmente operacional para a comunidade (A); registro da primeira aula do Curso de informática Básica (B) e , a entrega dos certificados de conclusão do Curso de Informática e do Curso Introdutório sobre Educação à Distância e ao Ambiente Moodle (3).

Figura 2 - Estruturação, momento de formação e certificação na comunidade de Setubal Janduís/RN

(A)

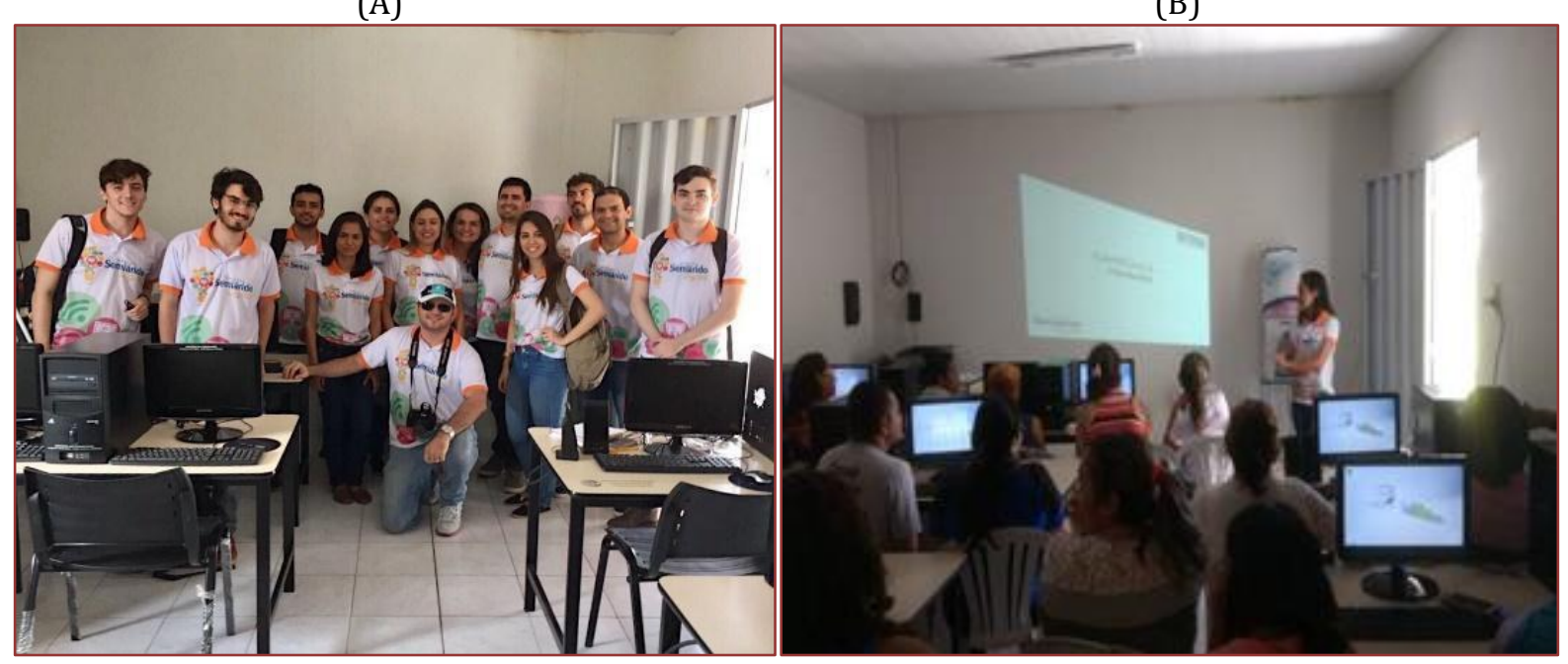

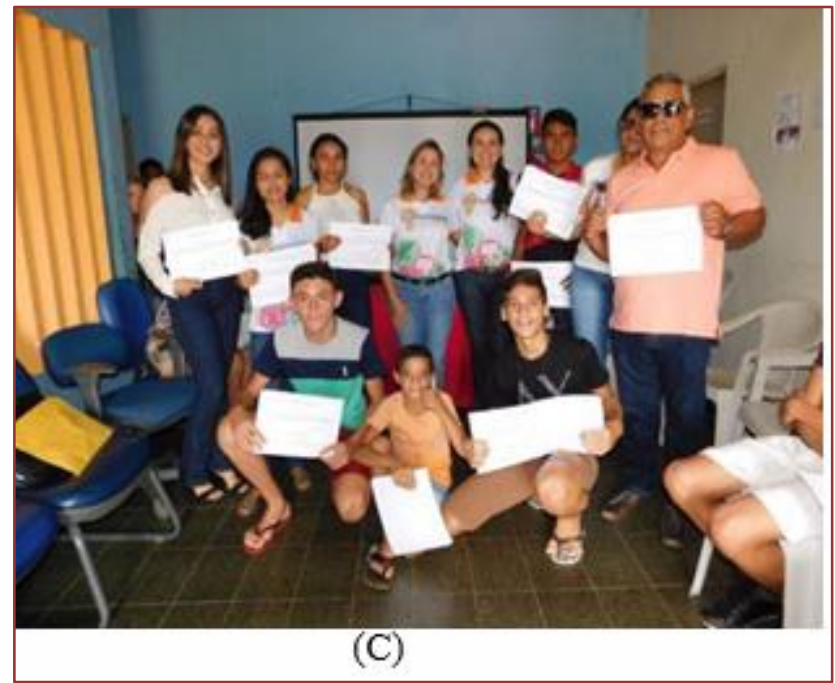

Fonte: Semiárido Digital, 2017.

Com relação aos municípios que já concluíram o curso de informática, percebeu-se que, apesar de muitos dos participantes terem assinalado no questionário que já tinham certo conhecimento em informática, como a maioria destas não possui computador em suas residências, muitos apresentaram dificuldades na execução das atividades, como por exemplo, em simples funções do teclado. Contudo, ao final do curso, estes consideraram o curso como uma atividade ímpar e que serviu de grande motivação para os mesmos aprofundar os conhecimentos obtidos e estudar os cursos à distância. Os alunos também se mostraram satisfeitos com a oportunidade de participar de um curso gratuito com conhecimentos relevantes ofertados por uma Universidade, e elogiaram a iniciativa de incluir regiões rurais que sofrem com a falta de acesso à informação e estruturação física precária.

Conforme visto, o uso das TICs nas comunidades contempladas pelo Programa mostra-se como uma possibilidade de incrementar as atividades produtivas á medida que procura instigar 0 
desenvolvimento profissional e pessoal do público envolvido, no seu espaço de vida e trabalho.

\section{CONCLUSÕES}

A utilização das TICs tem sido incorporada velozmente nas organizações brasileiras, como forma de otimizar as suas práticas administrativas e torná-las mais competitivas. Entretanto, esse processo não se deu de igual maneira, principalmente, quando se compara os diferentes segmentos de organizações. Apreende-se que quando se trata de organizações comunitárias, que possuem característica sem fins-lucrativos, o mesmo não acontece. Pois, essas mesmas organizações, na maioria das vezes, no que tange ao acesso das TICs, sempre ficam a mercê do interesse público. No contexto rural, essa realidade torna-se cada vez mais complexa, apesar das diferentes conquistas que as organizações podem adquirir através do uso dessas tecnologias.

As diferentes estratégias de inovações permitidas pelas TICs deverão ser pensadas mediante o contexto local e do objetivo real das organizações que delas se apropriarem. Diante desse cenário, elas surgem como possibilidade de fortalecer a vivência das pessoas na própria comunidade, seja através da formação presencial e/ou à distância, proporcionando a possibilidade de otimização das suas atividades produtivas e da valorização do local, através da inclusão digital e social. É dessa maneira que as ações do programa de extensão Semiárido Digital vêm disseminando suas ações.

Quanto à importância desta ação extensionista para a Universidade e para a comunidade acadêmica por parte dos alunos e servidores, é notório que o Programa Semiárido Digital atinge os objetivos no que tange ao cumprimento do tripé ensino-pesquisa-extensão como fator determinante para o aprofundamento dos conhecimentos gerados e obtidos na Universidade, propiciando a oportunidade de ampliação dos saberes e de suas habilidades, e colocando em prática o aprendizado acadêmico, com o adicional de poder auxiliar a comunidade externa, não apenas no quesito educacional e profissional, como também contribuir para melhorar a qualidade de vida das pessoas, respeitando a sua cultura, os seus costumes e as suas múltiplas possibilidades.

\section{REFERÊNCIAS}

[1] Leff, Enrique. Racionalidade ambiental: a reapropriação social da natureza. Rio de Janeiro: Civilização Brasileira, 2006. 551p.

[2] Müller, Ana Luíza. A construção das políticas públicas para a agricultura familiar no Brasil: o caso do Programa de Aquisição de Alimentos. Dissertação (Mestrado em Desenvolvimento Rural) - Universidade Federal do Rio Grande do Sul. Porto Alegre, 2007.

[3] Programa Semiárido Digital entrega Certificados de cursos a estudantes de Janduís/RN. Disponível em: <https://assecom.ufersa.edu.br/2017/07/19/programa-semiarido-digital-entrega- certificados-de-cursos-aestudantes-de-janduisrn/>. Acesso em: 23 set 2017.

[4] Schallenberg, Erneldo. Cooperativismo e desenvolvimento comunitário. Revista Mediações, Londrina, v.8, n.2, p.9-26, jul./dez. 2003. Disponível em: < http://www.uel.br/revistas/uel/index.php/mediacoes/article/view/9066 >. Acesso em 07 de outubro de 2017.

[5] Wanderley, Maria de Nazareth Baudel. O mundo rural como um espaço de vida: reflexões sobre a propriedade da terra, agricultura familiar e ruralidade. Porto Alegre: Editora da UFRGS, 2009. 


\section{Capítulo 8}

\section{A cantoria de viola no universo do semiárido brasileiro: Um ciclo de memórias que se ressignificam}

em espaços moventes.

Marcelo Vieira da Nóbrega

Edmilson Ferreira dos Santos

Maria Ignez. Novais Ayala

Resumo: No contexto do semiárido brasileiro, o cantador de viola consegue - através da sua habilidade poética e do simbolismo presente no seu imaginário - ressignificar os espaços, sentimentos, inquietações e aspirações, típicos do universo dos sujeitos que ali habitam. A força da memória expressa na sua narrativa, tida pelo cânone como de borda, traz à tona o que Moita Lopes (1995) chama de sentimento "dos povos do sul", ratificador da grande tensão, engendrada historicamente pelas políticas colonialistas dos chamados "do norte". Segundo Changeux (1974), Le Goff (2002), Zumthor (2010) e Barthes (1971), o comportamento narrativo tem uma função social que transcende a mera fixação mecânica da informação. Entendendo a memória como "não só ordenação de vestígios, mas releituras destes" (CHANGEUX 1974, p. 35), "reconstrução regenerativa" (LE GOFF, 2002, p. 430) e "onde tudo isso sobrevive" (HAVELOCK (1996, p. 274), este trabalho investiga a presença da força da memória no imaginário do cantador, através da análise de fragmentos de textos retirados de um corpus de 06 (seis) subgêneros textuais presentes no grande gênero cantoria de viola, e a partir de 04 (quatro) categorizações de memórias propostas: a) Memórias positivas de ressignificação; b) Memórias negativas de ressignificação; c) Memórias de ressignificação cíclica com os elementos da natureza; e d) Memórias de re(in)(a)comodação do homem no seu espaço. A proposição dessas categorias, ligadas a um gênero oral, objetiva melhor didatizar os procedimentos analíticos, considerando-se as variáveis envolvidas na formação dos subgêneros da cantoria, com forte presença da memória.

Palavras-chave: Semiárido, Cantoria de Viola, Memória ressignificada 


\section{INTRODUÇÃO.}

Este trabalho investiga de que forma a memória ressignifica - através do simbolismo presente no imaginário do cantador de viola - os espaços, sentimentos, inquietações e aspirações típicos do universo dos sujeitos imersos no chamado semiárido brasileiro. Todos são elementos envoltos no campo semântico dos sujeitos desta região, tais como: a seca climática, com todos os seus efeitos; a escassez d'água, bem como os dramas daí decorrentes; a peleja do viver projetada a partir de dois polos opostos, não necessariamente contraditórios: a celebração da vida em abundância centrada na fartura de alimentos minimamente necessários à sobrevivência, marcada pelo efêmero ambiente de chuva, e gerador de um estado momentâneo de felicidade, ou melhor, de bem-estar, se contrapondo ao longo período de escassez de água, responsabilizado este - ao menos nos discursos oficiais e oficiosos dos poderes organizados, e corroborado por grande parte de seus moradores - pelos dramas biopsicofisiológicos os mais diversos porque passam tais sujeitos.

Por outro lado, as inquietacões do poeta, expressas na tessitura de seu texto, são as mais diversas. A denúncia reiterada nos seus versos pelo abandono a que o povo do semiárido é submetido - sobremaneira no tocante à escassez ou ausência de políticas públicas ligadas ao aporte de recursos hídricos para a região - se funde com sentimentos de melancolia, tristeza, saudosismo e acomodação que, juntos, constituem o amálgama da sua produção poética. Nesta constituição de elementos a força reveladora da memória e suas diferentes categorizações forja-se como elemento crucial. Este trabalho se constitui como de relevância e pertinência para a pesquisa cientifica na medida em que pode contribuir para a discussão - através da análise de elementos e temáticas presentes no gênero cantoria de viola, gênero de tradição oral bastante cultuado e respeitado no imaginário dos sujeitos do semiárido brasileiro - dos grandes dramas humanos, sob as mais diferentes nuances - quer sejam psicológicas, sócio-políticas, econômicas, culturais e até políticas - porque passam tais sujeitos, historicamente oprimidos pela ausência de políticas públicas que possam lhes proporcionar melhor qualidade de vida.

A força da memória, expressa na cantoria de viola, de tradição oral - enquanto gênero típico do semiárido e tido pelo cânone como de borda - na verdade traz à tona um sentimento, aqui chamado de borda, o qual Moita Lopes (1995, p. 35) chama de sentimento "dos povos do sul," ratificador da grande tensão, engendrada historicamente pelas políticas colonialistas dos chamados "do norte", cujos efeitos, por exemplo, o semiárido padece até hoje, sob as mais diferentes perspectivas, sobre as quais uma análise mais acurada foge ao escopo deste trabalho.

Nesta perspectiva este trabalho propõe como objetivo geral investigar as diferentes categorizações de memória ressignificadas na produção poética, a partir do gênero de tradição oral cantoria de viola. Para o escopo de maior delimitação objetiva-se, por um lado, analisar de que forma e em que níveis tais categorias de memória podem contribuir enquanto representação simbólica e expressão artística dos anseios de um povo, para a melhoria de vida desse mesmo povo; e, por outro lado, analisar a força reveladora do simbolismo expresso na tessitura do gênero. Para tal, uma pergunta de pesquisa faz-se fundante: que importância exercem as diferentes categorizações de memória propostas, presentes na poesia do cantador de viola, suporte de uma escrita, de uma história, enquanto representação simbólica do universo social sócio-político e até cultural do semiárido brasileiro? Neste sentido, à luz desta questãoproblema, depreende-se a formulação da seguinte hipótese de pesquisa: a memória na cantoria de viola gênero da nossa tradição oral projetado no semiárido brasileiro - mais que a mera acumulação e reprodução mecânica de informações, ressignifica um histórico, complexo e contraditório, de dramas, anseios, aspirações, melancolias e lembranças, mediados pela força inescapável de elementos como água, morte e saudade.

\section{METODOLOGIA}

Esta pesquisa, de natureza quali-quantitativa, ao investigar a presença da força da memória no imaginário do repentista de viola, realiza-se com base em um Estudo de Caso e parte da análise de fragmentos de textos retirados de um corpus de 06 (seis) subgêneros textuais presentes no grande gênero cantoria de viola ${ }^{4}$, assim distribuídos: a) 02 (duas) canções ${ }^{5}$ a primeira intitulada Batente de Pau do Casarão, de autoria do poeta Dedé Monteiro, interpretada pela dupla de repentistas João Paraibano e Sebastiao Dias; a segunda, interpretada pelo repentista Sebastião da Silva, intitulada Ninguém Cortou meu Destino, de

\footnotetext{
${ }^{4}$ Ato de cantar, a disputa poética cantada, os desafios entre os cantadores no nordeste brasileiro (Cascudo, 2002, p. 238). 
autoria de Gabriel Lourenço; b) 02 (duas) Sextilhas 6 : a primeira realizada em praça pública momentos antes do sepultamento do poeta João Paraibano, no dia 03/09/2014, com a participação dos poetas Sebastião Dias, Rogério Menezes e outros; e a segunda, com a temática Coisas do Sertão, produzida em cantoria realizada no Sitio Serrote dos Bois, em Nazarezinho-PB, em 5/11/2013; c) 01 (um) Mote em Sete ${ }^{7}$ intitulado O Sertão a Seca Clama/ Cadê a Transposição? interpretado pela dupla de repentistas Severino Feitosa e Zé Viola, em Cantoria pé-de-parede ${ }^{8}$ realizada na cidade Teixeira-PB - no dia 03/07/2013; d) e um Mote em Dez intitulado A Viola não Foi mas Gostaria/ de Ter Ido com João pra Sepultura de autoria de Val Pimenta e interpretado pela dupla de repentista Jonas Bezerra e Afonso Pequeno, em cantoria realizada no dia 01/05/2015 na cidade de Itapetim (PE). A escolha de diferentes subgêneros ocorreu em função da necessidade de se mostrar a presença ostensiva da força da memória em cada um deles. A princípio foram selecionadas no suporte de vídeos Youtube, pelo menos 40 eventos de cantoria de viola e/ou gravações em CD/DVD cujas temáticas, de uma forma ou de outra, versavam sobre o tema memória. Em seguida optou-se pela escolha de 06 (seis) cantorias de viola que contemplassem diferentes subgêneros e que, indubitavelmente, expressassem o fenômeno da memória de maneira mais ostensiva. Daí a escolha dos seguintes subgêneros: Canção (02), Sextilhas (02), Mote em Sete (01) e Mote em Dez (01).

0 recorte teórico-metodológico investiga, com base nas pistas analíticas presentes nos textos propostos nos gêneros acima, as diferentes manifestações da memória de tais sujeitos-poetas, a partir de 04 (quatro) categorizações de memórias propostas, a seguir discriminadas: a) Memórias positivas de ressignificação; b) Memórias negativas de ressignificação; c) Memórias de ressignificação cíclica com os elementos da natureza; e d) Memórias de re(in)(a)comodação do homem no seu espaço. A proposição de tais categorias de memória, ligadas ao universo deste gênero de base oral, objetiva melhor didatizar os procedimentos analíticos, considerando-se o fato de que há grande complexidade de variáveis envolvidas na formação dos muitos subgêneros da cantoria de viola atravessadas todas pela força da memória.

\section{2 .A) REVISÃO TEÓRICA.}

A perspectiva teórica que embasa os estudos acerca de memória, fundante a este trabalho, parte da visão de Changeux (1974), Le Goff (2002), Zumthor (2010) e Barthes (1971). É consenso entre ambos que o comportamento narrativo tem uma função social, que transcende a mera fixação mecânica da informação. Segundo Le Goff, o ato mnemônico fundamental é justamente a socialização de tal comportamento narrativo "pois que é comunicação a outrem de uma informação, na ausência de um acontecimento ou do objeto que constitui o seu motivo" (LE GOFF, 2002, p. 424-5). Neste olhar Changeux ratifica que é a memória aqui entendida como "não só ordenação de vestígios, mas releituras destes" (CHANGEUX, 1974, p. 35). Nesta compreensão, tais processos podem fazer intervir centros nervosos muito complexos e uma grande quantidade do córtex. A ideia de ressignificação da memória aqui entendida vai ao encontro da chamada releitura, dimensão narrativa; não se trata de memória "palavra-palavra", mas sim do que Le Goff (2002) chama de "reconstrução regenerativa" (LE GOFF, 2002, p. 430). A memória, suporte de uma escritura ${ }^{9}$.

Ainda, segundo Barthes não há escritura que não carrega uma história, que é memória. Neste sentido, a memória seria responsável por impulsionar uma função, via escritura, que transcende a mera condição do ser linguagem. A ênfase dada à memória deve, nesta compreensão, estar atrelada a uma função social, aqui tratada como ressignificadora. Porque se as escrituras enquanto forma, segundo Barthes, são um valor que

${ }^{6}$ A Sextilha é uma estrofe com rimas deslocadas, constituída de seis linhas, ou seis versos de sete sílabas, nomes que têm a mesma significação. Na Sextilha, rimam as linhas pares entre si, conservando as demais em versos brancos (sem rima obrigatória). (Cf. em https://poesiaecordel.wordpress.com/metricas/). Data da consulta: 28/09/2016.

7 Na linguagem dos repentistas e ouvintes de cantorias o termo "mote em 7" refere-se a uma frase-tema, composta de dois versos metrificados com 7 sílabas poéticas, que deverá ser o desfecho das estrofes desenvolvidas pela dupla no atendimento ao pedido. (grifo nosso)

8 Essa denominação refere-se às cantorias tradicionalmente feitas em residências, podendo ser também em clubes, restaurantes, bares e até teatros. 0 termo faz referências à posição em que ficam os repentistas, geralmente encostados numa das paredes do estabelecimento, o que confere uma proteção e evita que alguns ouvintes posicionem-se atrás dos artistas, já que a interação face a face é a preferida por estes. (grifo nosso)

${ }_{9}$ Segundo Barthes conceitua-se como "forma engajada da fala que, ambiguamente, contém o ser e o parecer do poder, o que ele é e o que ele queria parecer" (BARTHES, 1971, p. 36). Seria, ainda segundo Barthes, "uma linguagem endurecida; impõe, pela sombra de seus signos, a imagem de uma fala construída antes de ser inventada." (BARTHES, 1971, p. 30). 
se recompõe a cada momento, uma vez que "nascem por força e pressão da história - que é memória - e da tradição (BARTHES, 1971, p. 25), então a memória constitui como que o motor propulsor das mudanças necessárias de que a sociedade necessita; é a voz, metáfora da lembrança, que autoriza a escritura a se projetar no mundo; é a responsável pelo afloramento da escritura, sob vieses os mais diversos; tem caráter ambíguo, uma vez que tanto libera a escritura para um além da linguagem, como busca na precedência da tradição parte de sua essência de ser memória, a ponto de Barthes reafirmar que "as palavras têm uma segunda memória que se prolonga misteriosamente em meio às significações novas" (BARTHES, 1971, p. 26).

Nesta perspectiva, ao tratar do próprio conceito de cultura, Havelock reafirma a importância da memória enquanto suporte de sobrevivência de qualquer manifestação cultural. Para este pensador "a cultura requer um corpo de tradições segundo as quais se há de viver; um tesouro de informação, regras de praxe normas de conduta apropriada. Só na memória narrativa é onde tudo isso sobrevive". (HAVELOCK (1996, p. 274). Portanto, o que lemos hoje, o que entendemos, enquanto letrados, como texto, era composição oral, portanto, de base acústica, ensinada e memorizada em todas as comunidades do mundo, em especial na grega. Por sua vez, Zumthor, ao discorrer acerca dos 02 eixos que definem a comunicação na performance, a partir das culturas de tradição oral, quais sejam: o que junta o locutor ao autor (produção, transmissão e recepção); e o que promove a união da tradição com a situação (que envolve conservação e repetição), distingue claramente o primeiro como sendo o da transmissão oral (base da performance) do segundo grupo, isto é, o da memória. (ZUMTHOR, 1993, p. 19). É neste segundo grupo que o pensador vai projetar que não pode haver performance ${ }^{10}$ sem uma ação memorial. Se se imaginar, por exemplo, a improvisação ${ }^{11}$, marca fundante da poesia de tradição oral, percebemos a complexidade de ações envolvidas, que envolvem tradição, reiteração e liberação de vozes (des)conhecidas que passam, via performance, a ser ressignificadas, tudo mediado pela memória, pela história. Segundo Zumthor

o improvisador possui o talento de mobilizar e de organizar rapidamente materiais brutos, temáticos, estilísticos, musicais aos quais se juntam as lembranças de outras performances e, frequentemente, de fragmentos memorizados de escrita. (ZUMTHOR, 2010, p. 254).

A memória trazida à baila, neste ato, na relação performática, ressignifica a tradição; a mobilização do novo, sob vários mecanismos linguísticos, sensitivos e suprassegmentais, impõe-se a liberação. Daí o caráter ambíguo que envolve o jogo da escritura, no qual a memória é mediadora fundamental. Ainda para Zumthor, o improvisador proclama a história, reivindica uma consciência (aqui exige-se do artista que este se remeta a uma memória, admoesta-o, precedentemente, a recorrer à tradição) e suscita uma voz (liberao ao novo, ao inusitado, ao ato criador). Se assim age, não pode haver história sem memória. É neste jogo de reclamar-se, na poesia dita oral, uma memória e, simultaneamente, impelir-se a uma reconfiguração que o próprio Zumthor vai ratificar que "toda oralidade nos aparece mais ou menos como sobrevivência, reemergência de um antes, de uma origem". (ZUMTHOR, 2010, p. 25). Se não se compreende desta forma, então se defende a tese de uma origem imutável e sectária das culturas de tradição oral, fato que poderia aumentar cada vez mais o fosso de preconceito folclorizante que elas sofrem, por parte das culturas hegemônicas comandas pelo monopólio da escrita.

Por outro lado, ao discorrer acerca de uma das cinco classificações de memória - a chamada memória transcendente - Geary, no Dicionário Temático do Ocidente, reproduz o pensar de São Tomaz de Aquino, quando este, ao classificar as cinco faculdades da alma humana (sensus communis, fantasia, imaginativa, cognitiva e memorativa), ratifica que "o poder cognitivo age sobre os fantasmas armazenados para produzir recordações” (GEARY, 1996, p. 178) (Grifo nosso). Para Santo Agostinho a memória era considerada a primeira das faculdades mentais, na Trindade Psicológica, por ele proposta: Pai (Memória como primeira pessoa; Filho (Intelligentia como segunda pessoa); e Amor (Voluntas, como terceira pessoa).

\footnotetext{
10 Aqui entendida como "ocorrido oral e gestual. Presença obrigatória de um corpo". Quando a voz fala (qualquer que seja e em diferentes circunstancias) renova-se então uma continuidade que se inscreve nos nossos poderes corporais, na rede de sensualidades complexas que fazem de nós no universo seres diferentes dos outros. E nessa diferença reside alguma coisa da qual emana a poesia" (ZUMTHOR, 2007, p. 39).

${ }^{11}$ Coincidência entre a produção e a transmissão de um texto. (ZUMTHOR, 2010, p. 254).
} 


\section{RESULTADOS E DISCUSSÃO.}

A presença das categorias de memórias propostas se justifica apenas para melhor sistematizar a complexa diversidade de sensações, sentimentos e aspirações nos quais a memória se apresenta, invariavelmente a partir da percepção imaginativa do cantador de viola. A relação, historicamente construída no semiárido brasileiro, entre o homem e a natureza sempre foi perpassada pela presença inevitável da água, esta, quando em abundância, gestora de bem estar e positividades; enquanto escassez, responsável pelas tragédias das mais diferentes naturezas, já presentificadas no senso comum destes sujeitos. Portanto, os marcadores semânticos presentes em um texto que, por exemplo, possam denunciar um processo de memória de re(in)(a)comodação do homem no seu espaço podem anular e/ou desqualificar os mesmos marcadores semânticos por ventura presentes na categoria de memória de ressignificação cíclica com os elementos da natureza.

Para efeito de melhor sistematização da análise os quadros abaixo discriminam, respectivamente, a ordem dos textos a serem analisados e o enquadramento dos textos propostos à análise conforme as categorias de análise propostas.

Quadro 01: identificação das modalidades de cantoria com seus respectivos intérpretes.

\begin{tabular}{|c|c|c|c|}
\hline & MODALIDADE & ASSUNTO & INTERPRETACAO \\
\hline 01 & Canção & Batente de Pau do Casarão & $\begin{array}{l}\text { João Paraibano e } \\
\text { Sebastião Dias }\end{array}$ \\
\hline 02 & Canção & Ninguém Cortou meu Destino & Sebastião da Silva \\
\hline 03 & Sextilha & $\begin{array}{l}\text { Realizada durante o sepultamento } \\
\text { do poeta João Paraibano. }\end{array}$ & $\begin{array}{l}\text { Sebastião Dias, Rogério Menezes e } \\
\text { outros }\end{array}$ \\
\hline 04 & Sextilha & Coisas do Sertão & $\begin{array}{l}\text { João Paraibano e } \\
\text { Valdir Teles }\end{array}$ \\
\hline 05 & Mote em sete & $\begin{array}{l}\text { O Sertão a Seca Clama/ } \\
\text { Cadê a Transposição? }\end{array}$ & Severino Feitosa e Zé Viola \\
\hline 06 & Mote em dez & $\begin{array}{l}\text { A Viola não Foi, mas Gostaria/ } \\
\text { de Ter Ido com João pra Sepultura }\end{array}$ & $\begin{array}{l}\text { Jonas Bezerra e } \\
\text { Afonso Pequeno }\end{array}$ \\
\hline
\end{tabular}

Fonte: arquivo pessoal.

Quadro 02: Classificação dos textos avaliados, conforme as identidades semânticas presentes e

observadas, de acordo com as características de cada categorização de memória proposta.

\begin{tabular}{|c|c|c|}
\hline TEXTO & $\begin{array}{l}\text { CATEGORIA DE } \\
\text { MEMÓRIA }\end{array}$ & IDENTIFICADORES SEMÂNTICOS \\
\hline 01 & $\begin{array}{l}\text { Memórias positivas } \\
\text { de ressignificação }\end{array}$ & $\begin{array}{l}\text { Fusão infância x natureza, através dos elementos de abundância que geram saudade: } \\
\text { suor, madeira, casa de taipa, roça, boi manso, canto no galo, sela no cavalo, cangalha } \\
\text { no jumento, água no cacimbão, fogão de lenha, oração, cachorro, gato. }\end{array}$ \\
\hline 02 & $\begin{array}{l}\text { Memórias negativa } \\
\text { de ressignificação }\end{array}$ & $\begin{array}{l}\text { As dores de um poeta a ter de abandonar a sua casa para seguir seu destino, marcadas } \\
\text { pelos seguintes elementos: conflitos familiares, tristeza, choro, abandono, solidão, tudo } \\
\text { pelo ideal de ser poeta, um dom de Deus; ser poeta e não amar ninguém como destino. }\end{array}$ \\
\hline 03 & $\begin{array}{l}\text { Memórias de } \\
\text { re(in)(a)comodação } \\
\text { do homem no seu } \\
\text { espaço. }\end{array}$ & $\begin{array}{l}\text { Tristeza e indignação pela perda do poeta; (in)aceitação e personificação da morte; } \\
\text { banalização da relação vida x morte: reencontro memorial com poetas mortos; } \\
\text { metáforas envolvendo elementos da natureza; morte como elemento de poeticidade. }\end{array}$ \\
\hline 04 & $\begin{array}{l}\text { Memórias de } \\
\text { ressignificação cíclica } \\
\text { com os elementos da } \\
\text { natureza. }\end{array}$ & $\begin{array}{l}\text { O ciclo da chuva como inspiração a partir dos seguintes elementos: inverno em } \\
\text { abundância, fartura (Jerimum, maxixe); canto do carão, cururu que bebe espuma, } \\
\text { trovão, relâmpago, nuvem, feijão na panela, milho que pendoa, capa de cupim por } \\
\text { sobre as águas da lagoa, voo da borboleta, cheiro de cabra no terreiro. }\end{array}$ \\
\hline 05 & $\begin{array}{l}\text { Memórias de } \\
\text { re(in)(a) comodação } \\
\text { do homem no seu } \\
\text { espaço. }\end{array}$ & $\begin{array}{l}\text { Indignação e revolta frente à condição imposta ao sertanejo (atraso nas obras da } \\
\text { Transposição do São Francisco): carrasco sem algodão, água sem feijão, gado sem } \\
\text { ração, fome do barbatão, seca inclemente, açudes secos, chão rachado, infertilidade da } \\
\text { fauna, incêndios e desertificação; sátira à ingerência do poder público (Presidente } \\
\text { Dilma e os políticos). }\end{array}$ \\
\hline 06 & $\begin{array}{l}\text { Memórias de } \\
\text { re(in)(a)comodação } \\
\text { do homem no seu } \\
\text { espaço. }\end{array}$ & $\begin{array}{l}\text { Tristeza e amargura pela perda do poeta; a morte que destrona o poeta e cria o mito: } \\
\text { o insubstituível, lugar especial no céu para o imortal, genialidade, acordo sublime com } \\
\text { a poesia, performance completa, estilo sem segunda via, faz poesia com "os olhos por } \\
\text { cima da visão"; processos de metonimização ("a viola gostaria de ter ido"; e "o } \\
\text { Nordeste parou"). }\end{array}$ \\
\hline
\end{tabular}


Quando associamos os textos 01 e 04, ligados a memórias positivas - quer sejam atreladas mais diretamente à construção de um imaginário que ressignifica ciclicamente a relação do homem com a natureza (texto 04); e em sua relação mais sensitiva de infância com esta mesma natureza (situação de enquadramento do texto 01) - aí percebemos que a história do semiárido brasileiro, à luz de um olhar para a representação que o cantador de viola faz - tem sido construída em paradigmas, cujas razões fogem do escopo deste trabalho, que têm sempre posto em evidência a relação quase sempre paradoxal entre, de uma lado, um estado momentâneo de chuvas (chamado erroneamente de inverno em nosso semiárido ${ }^{12}$ ), marcado por uma sensação de bem estar, fartura, bonança, momentânea felicidade; e de outro uma longa estiagem, momento de tristeza, mal-estar e estados longos de infelicidades, mas que, parece, fazem parte do imaginário destes sujeitos. A estrofe a seguir, extraída do texto 01, ilustra que mesmo em estados de saudosismo e registros positivos de memórias (marcas de ressignificação positiva de memória) a presença devastadora e marcada pela seca e abandono (marcas de uma ressignificação negativa de memória) persiste. Vajamos a estrofe:

\section{Qualquer dia eu tiro um retrato}

Do casebre e também de seu terreiro.

Da fazenda que antes fui herdeiro

E que agora ficou só no retrato.

No desprezo jogada pelo mato

Mas eu vou alisar com minha mão

Foi ali que passou a geração

Com a ordem de Deus foi adonai.

Minha mãe ficou grávida de meu pai

No batente de pau do casarão.

A condição climática mais uma vez interfere de forma devastadora na capacidade criadora do poeta. Mesmo em um texto declaradamente marcado por pistas de memórias ressignificadas de maneira positiva com o ciclo de bonanças e cumplicidades entre homem e natureza, o poeta denuncia que tal relação é fragilmente ameaçada pelo flagelo da estiagem. O marcador argumentativo “Quando" (10 verso), abaixo, é denunciador de tal risco, retirado das sextilhas do texto 04:

\section{Quando ano é bom de inverno}

Se escuta a gruta roncando.

Com quinze dias de chuva

Já tem maxixe vingando

E com mais trinta na frente

Tem jerimum fulorando. (grifo nosso).

Por sua vez a presença do tema da morte atravessa praticamente todo imaginário das poéticas de tradição oral, mais precisamente as que são perpassadas no espaço do semiárido brasileiro. Tida, irreversivelmente, como algo negativo, a temática transita na cantoria sob várias matizes. Nos textos 05 e 06 a temática se apresenta como efeito de duas situações distintas. No texto 05 , a presença da categoria memórias de re(in)(a)comodação do homem no seu espaço permite-lhe que tenha que tomar duas difíceis decisões: ou se se incomode, e tenha que se indignar, denunciando o descaso a que vem sendo submetido pelo atraso histórico das obras saneadoras de transposição do rio São Francisco; ou tenha que se (re)acomodar frente à dramática situação de penúria a que está submetido. Nas duas situações o fantasma da morte (representado aqui pela categoria memória negativa de ressignificação) vai estar sempre presente. Senão, percebam-se os seguintes versos, retirados do texto 05 :

\section{Sem transposição chegar}

Do jeito do prometido

\footnotetext{
$12 \mathrm{Na}$ verdade, a estação de Inverno ocorre entre Junho e agosto, ironicamente um período de franca estiagem em
} nosso semiárido. 
O Nordeste é ressequido

E eu vejo o chão rachar.

Sem ter chuva pra molhar

A porca perde o leitão

Besta perde o alazão

Inhambu fica sem chama

O sertão a seca clama

Cadê a transposição

Na situação em análise a sombra da morte se perfaz nas ameaças que atingem diretamente os elementos da natureza. Já no texto 06, mais uma vez a temática da morte se apresenta de forma ostensiva e reiterada já que o Mote em 10 pés A Viola não Foi mas Gostaria/ de Ter Ido com João pra Sepultura faz uma homenagem póstuma ao que é considerado, pelos poetas em atividade, um dos grandes ícones da cantoria de viola no Brasil, João Paraibano, morto em 03/09/2014, na cidade de Afogados da Ingazeira, onde morava. Neste momento, mais que atingir a natureza, a morte é inclemente com o poeta, o qual tanto a decantou em seus versos. A personificação da viola, a tristeza da perda, as lacunas da natureza são denunciadas na estrofe a seguir, extraída do poema:

\section{João foi um dos poetas renomados}

Professor do sertão, da natureza

Mas morreu e a cidade de Princesa

Perde um rei que não quis fazer reinados.

Todos sabem que os filhos de Afogados

Se afogaram num poço de amargura

E a viola sem brilho na pintura

Pela falta de João na companhia

A viola não foi mas gostaria

De ter ido com o dono pra sepultura

Por sua vez, no texto 03 , a comoção no dia sepultamento do poeta, através de uma homenagem sob a forma de sextilhas em praça pública, em meio a uma multidão, traz à luz a força da fusão de duas categorias de memória: memórias de reacomodação frente à situação, marcada pela indignação contra a morte precoce, em confluência com a profunda tristeza, enquadrada na categoria memória de ressignificação negativa, não necessariamente de infância. Senão vejamos os versos a seguir:

Quero afirmar pra vocês

Morte não tem solução

E que a vida tem limite

Morte não tem coração

Porque se ela tivesse

Não tinha matado João

Com essa morte de João

Eu sinto a alma inquieta

A seleção da viola

Hoje se encontra incompleta

Nós perdemos um irmão

E o céu ganhou um poeta 
A sensação de "alma inquieta", quando ligada à constatação de que a "morte não tem coração," já que matara o poeta, denuncia a força de uma memória que performatiza um estado de indignação, de incomodação do ser frente à situação que lhe fora imposta, típico do que aqui se denomina de Memórias de re(in)(a)comodação do homem no seu espaço. Entretanto, a atmosfera de tristeza e a incompletude são características da categoria de memória negativa de ressignificação.

\section{CONSIDERAÇÕES FINAIS}

A temática ligada à morte da natureza, direta ou indiretamente, é rememorada e ressignificada na cantoria de viola, em quase todos os textos avaliados, como desfecho quase que natural e apocalíptico de uma condição a que estes seres deverão estar sempre submetidos. Desta forma, nos textos avaliados, sentimentos como tristeza, perda, indignação, readaptação, secas climáticas e cíclicas, acomodação, melancolia e tristeza parecem nos textos - enquadrados nas categorias memórias negativas de ressignificação e memórias de re(in)(a)comodação do homem no seu espaço - se sobreporem às temáticas ligadas a sentimentos de bem estar envolvidos nas relações do homem com a natureza, tais como: fartura de alimentos, bonança de água e os demais sentimentos e sensações daí decorrentes, aqui inseridas nas seguintes categorias de memória: positiva de ressignificação e memória de ressignificação cíclica com os elementos da natureza. A tese basilar da conceitualização da ideia de memória, enquanto releitura de vestígios, segundo Changeux (1974), ou a marca da chamada reconstrução regenerativa, de Le Goff (2002) são marcantes no imaginário do cantador de viola. A reiteração de temáticas que se reinventam na realidade de tais sujeitos e que, de maneira direta, interfere em suas vidas, é presença constante em seus textos. 0 simbolismo da água, ou da sua escassez, reflete-se diretamente na constituição de uma poética cujos vestígios de memórias são perpassados ciclicamente pelo ostensivo jogo entre vida - ora em abundância e plena de alegria, bonança e bem estar - e morte, marcada pelas tragédias do cotidiano, bem conhecidas no nosso imaginário, quando se trata de Nordeste.

\section{REFERÊNCIAS}

[1] Barthes, Roland. O Grau Zero da Escritura. (Tradução de Anne Arnichand e Álvaro Lorencini). São Paulo: Cultrix, 1971.

[2] Changeux, J.P. Discussão entre Changeux e A. Danchin: aprender pela estabilização seletiva de sinapses nos Cursos de Desenvolvimento. (Tradução do Francês sem autoria especificada). Paris: 1974.

[3] Le Goff. Jacques; SCHMITT, Jean-Claude. Dicionário Temático do Ocidente (Vol. II). Bauru (SP): Edusc, 2002.

[4] Moita Lopes, L. P. (Org.) Por uma Linguística Aplicada Indisciplinar. São Paulo: Parábola Editorial, 2006.

[5] Zumthor, Paul. Introdução à Poesia Oral. (Tradução de Jerusa Pires Ferreira, et. al). Belo Horizonte: Editora da UFMG, 2010.

[6] _. Performance, Recepção e Leitura. (Tradução de Gerusa Pires Ferreira e Suely Fenerich). São Paulo: Cosac Naify, 2007.

[7] Zumthor, Paul. A Letra e a Voz: a "literatura medieval". (Tradução Amálio Pinheiro e Jerusa Pires Ferreira). São Paulo: Companhia das Letras, 1993.

\section{ENDEREÇOS ELETRÔNICOS REFERENTES ÀS MODALIDADES DE CANTORIA DE VIOLA.}

Modalidade 01: Canção: Disponível em: >https://www.youtube.com/watch?v=5U5DOtlHOxc<. Data da consulta: 30/09/2016.

Modalidade 02: Canção: Disponível em: >https://www.youtube.com/watch?v=FVJqe0TThX4<__Data da consulta: 30/09/2016.

Modalidade 03: Sextilhas: Disponível em: >https://www.youtube.com/watch?v=wb80LuM77b0 $\leq$. Data da consulta: 30/09/2016.

Modalidade 04: Sextilhas: Disponível em: >https://www.youtube.com/watch?v=4pVa4BV17fE<_Data da consulta: 30/09/2016.

Modalidade 05: Mote em sete: Disponível em: Disponível em: >https://www.youtube.com/watch?v=8vl_uTiOLsA<. Data da consulta: 30/09/2016.

Modalidade 06: Mote em dez: Disponível em: >https://www.youtube.com/watch?v=NqRCHJZRZMQ<. Data da consulta: 30/09/2016. 


\title{
Capítulo 9
}

Saberes tradicionais do semiárido piauiense: Proposta de inclusão curricular

\author{
Maria Alveni Barros Vieira \\ Adauto Neto Fonseca Duque \\ Maria das Dores de Sousa \\ Thatianny Jasmine Castro Martins de Carvalho \\ Luiza Xavier de Oliveira
}

Resumo: Nesse trabalho, objetivamos apresentar as atividades extensionistas realizadas por um grupo de professores e alunos das Universidades Federal e Estadual do Piauí, Campus de Picos, que culminaram na produção de um inventário dos sujeitos, saberes e práticas tradicionais de uma parte do semiárido piauiense, situada nos espaços fronteiriços com o Ceará, Pernambuco e Paraíba. Trata-se de um trabalho vinculado aos aportes teóricos e metodológicos da História Cultural em suas interfaces com a História da Educação, cujas análises encontram-se articuladas a partir do entendimento de educação definido por Thomas (2000) como parte essencial do conjunto de valores que caracterizam a formação cultural de uma sociedade, sem perder de vista suas diferentes formas de manifestação. Também fizemos uso da noção de Práticas Culturais delineada por Chartier (2001) como os modos de fazer dos sujeitos históricos, por nos permitir reconhecer, junto aos partícipes, uma identidade social e uma maneira própria de estar no mundo. Os inventários realizados até o presente momento parecem indicar que $o$ semiárido piauiense é desconhecido de grande parte da população do Estado. Até mesmo quem nele habita fala do semiárido como um espaço distante de suas vivências cotidianas, evidenciando uma certa inconsciência do sujeito com a história e a cultura local. Os indícios também nos permitem inferir que a ausência de um mapeamento histórico cultural dos sujeitos, dos saberes e das práticas tradicionais e sua organização sistemática em forma de livros didáticos e paradidáticos, documentários e cartilhas não favorecem uma maior divulgação dos mesmos entre as novas gerações.

Palavras-chave: Saberes, Práticas, Educação, Semiárido, Piauí. 


\section{INTRODUÇÃO}

\subsection{O SEMIÁRIDO QUE HABITAMOS, OS SABERES TRADICIONAIS QUE ALI CULTIVAMOS}

De acordo com o Instituto Brasileiro de Geografia e Estatística (IBGE, 2016), o semiárido brasileiro compreende uma extensão total de $982.563,3 \mathrm{~km}^{2}$. Dessa área, a Região Nordeste concentra um total de 89,5\%, abrangendo a maioria dos estados nordestinos, com a exceção do Maranhão, e o Estado de Minas Gerais, situado na Região Sudeste, que possui os 10,5\% restantes $\left(103.589,96 \mathrm{~km}^{2}\right)$.

Numa pretensa subdivisão (geo) cultural o estado do Piauí compreende 224 municípios, dos quais 149 encontram-se situados no semiárido. É sobre essa parte peculiar do território piauiense que detemos nossos estudos, tanto no que tange a sua formação étnico-cultural e as identidades sociais, quanto a valorização da história e das memórias dos seus moradores. São grupos diversos em trabalho, trajetórias históricas e marcados pelo costume e tradições repassadas sob o viés da ancestralidade, constituindo práticas sociais, políticas, econômicas e culturais. Práticas e saberes transmitidos por sucessivas gerações através da memória, forjando suas representações e preservando seu patrimônio histórico-cultural material e imaterial. No nosso entendimento, aqui entra o papel da escola como agente de fomento, produção, divulgação e preservação de cotidianos próprios a esses grupos sociais do semiárido.

Aqui rememoramos que a penetração e o repovoamento de parte do Sertão de Dentro, hoje conhecido como Vale do Guaribas e Vale do Canindé, no centro-sul piauiense, aconteceram através dos criadores de gado vacum e cavalar, vindos da Bahia, vinculados aos senhores da Casa da Torre de Tatuapara. Bandeira (2000) observa que, desde os anos de 1663, o capitão Garcia d'Ávila, seu filho Francisco Dias d'Ávila II e seus sócios Domingos Afonso Sertão e Julião Afonso Serra penetraram na região que vai do médio São Francisco até o rio Parnaíba, limites atuais dos Estados do Piauí e Maranhão.

Por conseguinte, desde fins do século XVII, homens, mulheres e crianças; brancos, negros, mestiços, índios; livres ou escravizados, ali se instalaram às margens dos rios Guaribas e Canindé, onde iriam erigir fazendas, sítios, retiros, currais e capelas. Em estudos realizados acerca da formação da sociedade picoense, Vieira (2005) relata que, nas povoações que então se iniciavam na região centro-sul do Piauí, as bases da economia local assentavam-se na pecuária extensiva, contribuindo para a afirmação de um ideal de homem que se revelava através da imagem do vaqueiro, do criador, do negociador de gado.

Em estudos anteriores, Brandão (1995) afirmava que no Piauí colonial foi se instituindo uma sociedade de vaqueiros, onde a criança aprende, desde cedo, na labuta cotidiana do dia a dia, as atividades de pastoreio. Castello Branco (1942), em obra sobre a civilização do couro no Piauí, bem descreve tais atividades:

[...] laça bezerros, peia, auxilia na marcação, ajuda a domar garrotes e potros bravos ou a pegar o lote de cavalos da sela solto no 'cercado' amplíssimo ou no baixão. Frequentemente levanta de madrugada para ordenhar vacas. (CASTELLO BRANCO, 1942, p.4).

Não por acaso, as identidades piauienses projetadas no imaginário social, recorrem constantemente à imagem do vaqueiro, à cultura do boi, da vaquejada, ao uso dos utensílios de couro, seja nas cantigas de roda, seja nas brincadeiras infantis. O escritor folclorista piauiense, Silva (1988), não ignorava a permanente influência de uma cultura pastoril nas folganças populares piauiense do século XX como consequência da criação e da exportação do gado ali desenvolvidas nos séculos anteriores e muitas vezes expressa em eventos nacionais que contam com a participação de comitivas piauienses:

O meu boi morreu,

Que será de mim?

Manda buscar outro,

Ó maninha,

Lá no Piauí! (SILVA, 1988, p.93).

Também a historiadora Nunes (2003, p.88) observa que no universo das manifestações populares do povo piauiense no século XXI, as influências dos séculos de colonização ainda se fazem presentes no imaginário coletivo representadas "[...] pelas habitações, mobiliários, artesanatos e religiosidade [...]", além de outras expressões, a exemplo dos cantos, das danças, das comidas e das lendas, principalmente.

Decerto que esses autores não desconhecem as influências da globalização em expropriar das referências, os modos de vida locais do povo habitador do semiárido. Também não ignoram a decadência das práticas culturais de uma comunidade em troca de um padrão fabricado pelo mercado financeiro amplamente 
divulgado pelos meios de comunicação de massa. O historiador piauiense Celestino (2003), por exemplo, há tempos nos alerta sobre os riscos de agravamento dos valores de uma comunidade que são morais, mas também culturais:

Um dos resultados negativos da globalização é um amplo desenraizamento que desfaz modos de vida locais, expropria milhões de seres humanos de suas referências culturais e de suas próprias vidas. Assim, todo um processo cultural entra em decadência e, em troca, é oferecido um padrão fabricado pelo consumo, que tem na mídia um emulador permanente, pasteurizando todo e qualquer tipo de diferença. (CELESTINO,2003, p. 420).

Todavia, apesar da globalização dos costumes nos tempos contemporâneos, observamos, através de pesquisas acadêmicas realizadas no âmbito das universidades estadual e federal do Piauí, que parte dos saberes e práticas tradicionais teimam em permanecer como fatores que respondem pela marcante originalidade do povo que habita o semiárido dos sertões nordestinos, especificamente, o semiárido piauiense: a maneira de pensar, falar e agir, suas expressões culturais e artísticas, suas crenças, valores, usos e costumes, a relação de suas vivências com a seca, a tradição, a fé, a religião e a política, suas formas de sociabilidades e práticas educativas realizadas em tempos e espaços diferenciados.

Falta-lhes, todavia, a consciência plena de que todos esses sentimentos, sensações e afinidades são pertinentes e se desenvolvem num espaço geográfico específico, denominado semiárido piauiense.

\section{METODOLOGIA}

\subsection{A SUPOSTA INVISIBILIDADE DO SEMIÁRIDO PIAUIENSE, OU O QUE NÃO QUEREMOS VER}

É verdadeiro afirmar que, com a intensificação do processo de globalização na década de 1990, difundiuse a ideia de uma pretensa uniformização cultural no Brasil. Consequentemente foram desencadeados movimentos de resistência a essa possibilidade e o mais importante deles foi o despertar para o conhecimento, reconhecimento e preservação da identidade cultural de cada grupo. Não por acaso, no ano de 2012, o Brasil, assim como outros 121 (cento e vinte e um) países, ratificou o que foi estabelecido na Convenção sobre a Proteção e a Promoção da Diversidade das Expressões Culturais da Unesco. De acordo com essa Convenção, nosso país tem obrigação de criar políticas e leis que protejam e promovam todas as expressões culturais, entre elas as populares e tradicionais. Isso significa garantir os direitos daqueles que detêm os conhecimentos e produzem as expressões dessas culturas. Também significa dar condições sociais e materiais para a transmissão desses saberes e fazeres.

Estudos realizados por Nepomuceno (2005) indicam que a região nordestina foi uma das primeiras a evidenciar preocupação com a necessidade de preservar e divulgar sua identidade cultural, o que só foi possível naquelas comunidades que, de alguma forma, mantinham suas tradições em evidência. Esse não foi o caso do semiárido piauiense.

O semiárido piauiense é desconhecido da maioria da população do estado. Até mesmo quem nele habita, fala do semiárido como um espaço distante de suas vivências cotidianas, a exemplo do que ocorre nas escolas do ensino fundamental, quando vão estudar as regiões brasileiras. A historiadora Dias (2003, p.216) nos diz que, sobre a história cultural do Piauí, "Falta ainda muito a ser estudado e pesquisado. Existem enormes lacunas no ensino universitário, fundamental e básico".

Em pesquisas realizadas sobre a valorização da História Local nos currículos das escolas situadas no semiárido piauiense, Silva e Vieira (2015) constataram a ausência de conteúdos sobre o tema na maioria absoluta das instituições de ensino fundamental investigadas. No entendimento das professoras do ensino fundamental que participaram da pesquisa de Silva e Vieira (2015), o desconhecimento da História Local era promovido, principalmente, pela falta de informações sistematizadas acerca de tais conteúdos. Todas foram unanimes em concordar que a valorização da História Local no Ensino Fundamental é o ponto de partida para esse processo de formação do cidadão, do agente histórico, conhecedor de suas tradições culturais.

De fato, desde o ano de 2006, um grupo de professores da Universidade Federal do Piauí vem desenvolvendo projetos com a finalidade investigar o processo histórico de formação e desenvolvimento de algumas comunidades do semiárido piauiense, objetivando sistematizar um conjunto de saberes que possa ser utilizado como material didático nos primeiros anos do ensino fundamental. Inicialmente, os trabalhos recaíram sobre a compilação de obras acadêmicas e literárias que versassem de forma direta ou indiretamente sobre o tema, assim como a busca por depoimentos de pessoas consideradas agentes 
praticantes dos saberes tradicionais. Tivemos como resultado a coletânea organizada pela professora Maria Goreth de Sousa Varão com título Picos: histórias que as famílias contam (2007), resultado do projeto de extensão "Produção de textos: histórias de vida" (2006).

Seis anos depois, no ano de 2012, foram desenvolvidos projetos de pesquisa que tiveram como proposta pedagógica o levantamento de informações históricas sobre diferentes aspectos de algumas comunidades do semiárido piauiense, assim como a produção de materiais didáticos para o ensino de História Local nos primeiros anos do ensino fundamental. Tratavam-se de pesquisas respaldadas nos aportes teóricos da História Local como abordada por Silva (1998) e subsidiada pelo colhimento de informações na tradição oral e na leitura de obras literárias.

Logo na realização das primeiras etapas das pesquisas, constatamos que a produção de materiais didáticos no campo da História Local é complexa, exige estudos profundos sobre a história dos grupos nos diferentes níveis da vida coletiva e nas suas relações com outros grupos e com a sociedade nacional. Ademais, esses trabalhos eram desenvolvidos por alunos cursando o último período do curso de Pedagogia, promovendo, ao finalizarem o curso, o processo de descontinuidade das investigações, muito embora tenha sido possível a produção de textos sobre a temática, publicados no V FIPED (2013) como:

i) Histórias que deveriam ser contadas no ensino fundamental, com autoria das professoras Maria Alveni Barros Vieira e Maria Goreth de Sousa Varão, além das alunas Antônia Agna Alves de Andrade e Valéria Belo de Moura Silva, que consiste no relato de parte de um projeto de pesquisa que teve como finalidade investigar o processo histórico de formação e desenvolvimento da sociedade picoense, objetivando sistematizar um conjunto de saberes que possa ser utilizado como material didático nos primeiros anos do ensino fundamental. As informações levantadas pela equipe de pesquisadoras, permitiram concluir que parte da população rural da municipalidade de Picos, situada no semiárido piauiense, ainda vivia em consonância com os ciclos da natureza. Pelos relatos analisados eram as estações do ano que conduziam as principais atividades de trabalho e de lazer realizadas naquela época e, por conseguinte, conduziam a vida cotidiana da comunidade rural picoense: a) Estação Chuvosa (dezembro, janeiro, fevereiro e março) considerada o tempo da fartura de frutas e cereais; b) Fim da Estação Chuvosa (abril e maio), tempo do fim das chuvas, quando ocorria o início dos preparativos para o plantio do alho e da cebola no leito do rio. Também era a época das festividades católica conhecida como Semana Santa, quando se aproveitava para visitar parentes, compartilhar alimentos (abobora, melancia, ata), momento em que ocorria a feitura de comidas típicas desse período (quibebe de abóbora, pamonhas, canjica, feijão verde temperado com manteiga da terra e nata, doce de leite, coalhada); c) A desmancha da Mandioca e a moagem da Cana (junho, julho e agosto) tempo da frieza, tempo de desmanchar a mandioca para fazer farinha e goma. d) Período de Espera (setembro, outubro e novembro), tempo do famoso b.r.o.bro, do abrasamento da terra, período reservado para o remonte das cercas, bem como a broca, o destocamento e encoivaramento das terras. Os mais antigos lembraram que esse era o tempo preferido dos pais de família para a contratação do mestre-escola.

ii) História Local em sala de aula: uma proposta de produção de materiais didáticos para as primeiras séries do ensino fundamental, mais uma vez com autoria das professoras Maria Alveni Barros Vieira e Maria Goreth de Sousa Varão, e a participação das alunas Janaina de Moura Cavalcante e Jéssica Priscila de Jesus Silva. Assim como no artigo citado anteriormente, nesse trabalho, também foi realizado o relato de um projeto de pesquisa desenvolvido na Universidade Federal do Piauí - Campus de Picos. Aqui, a proposta consistia em sistematizar um conjunto de saberes que pudesse ser utilizado como material didático nos primeiros anos do ensino fundamental. As informações, então levantadas junto à Coordenação do Ensino Fundamental do Município de Picos (PI), ocorrido em meados do ano de 2012, permitiu constatar a inexistência de qualquer material didático (livros, apostilas, jogos, mapas, etc) para o ensino de História Local no primeiro ciclo do ensino fundamental. Mesmo em escolas particulares, as pesquisadoras se depararam com a ausência de material didático específico, enquanto outras utilizavam textos avulsos com informações fragmentadas e, por vezes, equivocadas.

Ainda no ano de 2012, foi cadastrado o projeto de pesquisa intitulado História da sociedade picoense para o ensino fundamental, tendo sido desenvolvido até o ano de 2014, sem maiores desdobramentos por descoberta dos pesquisadores da necessidade de uma pesquisa prolongada e rigorosa sobre os tempos coloniais daquela parte do semiárido piauiense, sob o risco de reproduzir equívocos históricos nas escolas. Todavia os relatórios finais foram devidamente apresentados e vêm subsidiando outros trabalhos que adotam a cidade como objeto de estudo. Com perspectivas metodológicas similares, ainda foi produzido o Trabalho de Conclusão de curso sobre o ensino da História Local nas escolas da cidade de Francisco Santos, localizada no semiárido piauiense, no ano de 2015. Nenhuma dessas ações promoveram o impacto esperado. 
A escassez de trabalhos acadêmicos que adotassem o semiárido piauiense, especificamente, o semiárido que faz parte da região conhecida como Vale do Guaribas e Vale do Canindé, se fez mais evidente por ocasião da elaboração do currículo do curso de medicina a ser implantado no campus Senador Helvídio Nunes de Barros (UFPI $\backslash$ Picos) em 2017. A comissão, então formada por 18 (dezoito) professores das áreas de Educação, Saúde e Ciências da Natureza, com a finalidade de elaborar a Proposta Pedagógica do curso, se deparou com a ausência de informações sistematizadas e analisadas na academia que pudessem respaldar o perfil regional do curso. A solução foi a compilação e exposição de dados "crus" apresentados pela Proposta Plurianual da Prefeitura Municipal de Picos (2016-2017).

A conclusão a que parte da comissão supracitada chegou foi: não enxergamos a comunidade em que vivemos e trabalhamos, não sabemos o que é o semiárido piauiense, realizamos pesquisas e ações extensionistas aplicáveis em qualquer parte do Brasil e, a exemplo do que já afirmava Morais (1989, p.154) em fins da década de oitenta, ressaltaram que o problema dos acadêmicos brasileiros continua sendo o grande orgulho da "[...] ventriloquia em seu discurso de empréstimo".

\section{RESULTADOS E DISCUSSÕES}

\subsection{O SEMIÁRIDO NO CENTRO DAS ATENÇõES ACADÊMICAS, O ACESSO AO CURRÍCULO}

Em fins do ano de 2017, foi cadastrado na Universidade Federal do Piauí um amplo Programa de Extensão denominado Tradições do semiárido piauiense, a ser desenvolvido até o final do mês de novembro de 2019. Elaborado por um conjunto de 11 (onze) professores das áreas de Pedagogia, História, Sociologia, Letras e Sistemas de Informação, a proposta se desdobra em dois projetos complementares entre si, a saber:

i) Sujeitos, saberes e práticas tradicionais no semiárido piauiense, que tem por objetivo realizar um amplo mapeamento dos saberes e das práticas tradicionais ainda presentes em diversas comunidades do semiárido piauiense, mais especificamente na região centro-sul do estado. Não obstante a proposta intenciona também identificar os mestres das artes e dos ofícios, das rezas, dos cantos e dos contos, mestres dos reisados, das vaquejadas, das farinhadas e das moagens, mestres das danças, das comilanças e do curandeirismo, mestres capazes de descrever parte das práticas e dos saberes há muito esquecidos pela maioria da população. A compilação dos dados vem sendo efetuada por meio de entrevistas semiestruturadas, procurando sistematizar as informações através de 4 (quatro) eixos: a) trajetória de vida dos mestres; b) saberes e práticas tradicionais do seu domínio; c) formas de aprendizagem; d) formas de ensinamento e aprendizes. Na fase atual, os alunos extensionistas encontram-se no processo de transcrição das entrevistas, editoração das imagens e elaboração de artigos científicos.

ii) $\quad 0$ segundo projeto traz como título Acervo digital dos sujeitos, saberes e práticas tradicionais do semiárido piauiense e intenciona transformar o material produzido pelo projeto anterior em arquivo contendo as entrevistas, fotografias, imagens e textos produzidos pelos partícipes do projeto supracitado, com a finalidade específica de levar, a um público extenso, informações e conhecimentos sobre as tradições do semiárido. Essa proposta encontra-se no processo de desenvolvimento de uma plataforma virtual em parceria com a Universidade Federal do Piauí para a disponibilização dos dados a todos os usuários interessados na temática, especialmente professores da educação básica.

0 respaldo teórico geral das duas propostas encontra-se assente nas afirmações de Barbizani (2010), quando ressalva a importância de reconhecer a cultura digital como um tipo de área do conhecimento que gestiona e intercruza as informações e conhecimentos produzidos pela humanidade, preserva e divulga saberes tradicionais, evitando, assim, que os mesmos desapareçam. É, pois, com os objetivos de sistematizar, divulgar e preservar por meio de ferramentas digitais os sujeitos, os saberes e as práticas tradicionais do semiárido.

Uma reação mais contundente emerge desse mesmo coletivo de professores, ao elaborarem uma proposta de Mestrado Profissional para ser apresentada à Coordenação de Aperfeiçoamento de Pessoal de Nível Superior (CAPES) em 2019. Trata-se de um projeto minuciosamente construído que traz como objetivo central investigar a educação escolar básica no contexto sociocultural do semiárido nordestino e, mais especificamente, do semiárido piauiense, além de apresentar propostas de intervenção nos currículos e práticas educativas.

Apoiada nas reflexões de Moreira (2004), a comissão de elaboração da proposta justifica a sua feitura, afirmando que, embora pretendam desenvolver estudos em uma área de conhecimento acadêmico relativamente ancorada por um certo número de pesquisas realizadas por outras instituições de ensino superior, é possível observar que os resultados de tais investigações permitem, tão somente, comparações 
aproximativas com o cenário educacional do semiárido nordestino, posto que muitas são as variações e variedades de sujeitos, processos e práticas culturais presentes no território brasileiro, em função dos cenários locais, dos saberes e fazeres tradicionais de comunidades específicas.

A comissão firma, ainda, não desconhecer as exigências do cenário político e econômico atual sobre a formação continuada de professores da educação básica, para atuarem numa sociedade globalizada em vertiginosa transformação e imprevisibilidade (GATTI, 2009; NÓVOA, 2009; LIBÂNEO, 2014). Mas volta a inferir veementemente que, apesar dos esforços de comunidades de pesquisadores internacionais e de várias regiões brasileiras, o corpo de conhecimento até então construído e apresentado, de forma universalista, não produziu impactos significativos no cotidiano escolar local, por não dialogar intimamente com a realidade onde as práticas educativas são desenvolvidas.

Desta feita, delimita como possíveis alunos do mestrado professores em exercício das suas funções na educação básica do semiárido nordestino e, mais especificamente, semiárido piauiense. Certamente, essa proposta de pós-graduação desempenham uma função extremamente importante, ao proporcionar a aproximação entre a academia e os outros níveis escolares, ao produzir e socializar conhecimentos científicos, ao contribuir para a formação do professor crítico, reflexivo, transformador da sua realidade no espaço escolar, principalmente.

Como parte desse coletivo de professores, concordamos com Oliveira e Almeida (2009), ao afirmarem que

O conhecimento só tem um verdadeiro significado quando é colocado na prática, quando se percebe como algo importante, ligado às atividades diárias do sujeito, fazendo parte das relações sociais, dentre aquelas estabelecidas no seu ambiente de trabalho (OLIVEIRA; ALMEIDA, 2009, p. 165).

Defendemos ser preciso buscar alternativas mais apropriadas do que as iniciativas que se limitam à sondagem da realidade para fins de trabalhos acadêmicos e entendemos que a formação de grupos de trabalho e estudo composto por profissionais em exercício nas atividades escolares no ensino fundamental e médio é um caminho a ser experimentado para a montagem de intervenções concretas no currículo escolar, propondo conteúdos e atividades educativas vinculadas à realidade que nos cerca. No nosso caso, o semiárido do centro-sul piauiense, principalmente.

\section{CONSIDERAÇÕES FINAIS}

Depois de tímidas iniciativas, pesquisas isoladas, que objetivavam discutir os saberes e as práticas tradicionais do semiárido, mas que serviram para constatarmos que a História Local, quando trabalhada nas escolas, apresenta-se como um apêndice de conteúdos mais universais, concluímos que a academia tem um papel relevante nas discussões que enveredam de alguma forma na construção da identidade do povo do semiárido piauiense e na preservação das suas práticas e dos seus saberes tradicionais. Mas não é suficiente.

Faz-se necessário o extremo auxílio dos professores da educação básica. Não como mero partícipes de pesquisas na condição de entrevistados, mas na promoção de uma formação continuada em programas de pós-graduação para que os mesmos possam ultrapassar, como ressalva Lüdke e Cruz (2010, p.114), a condição de "[...] meros repetidores de um saber cristalizado, mas testemunhas vivas e participantes de um saber que se elabora e reelabora a cada momento, em toda parte."

Professores habilitados para interferirem adequadamente, na construção e na implementação de propostas curriculares, na proposição, na gestão e na coordenação de políticas educacionais, assim como nos processos avaliativos do sistema de ensino em que atuam, capazes de interferirem na qualidade do ensino, em âmbito local, regional e nacional, sem deixar de considerar os processos de transformação decorrentes dos contatos interculturais e da globalização da cultura. 


\section{REFERÊNCIAS}

[1] Bandeira, Luiz Alberto Vianna Moniz. 2000 - O Feudo - A Casa da Torre de Garcia d'Ávila: da conquista dos sertões à independência do Brasil, Rio de Janeiro, Editora Civilização Brasileira, 2000.

[2] Barbizani, Vinícius. A Cultura da Convergência. Disponível em: http://imasters.uol.com.br/artigo/10688/webmarketing/a_cultura_da_convergenc ia/ Acesso em: 22 jan. 2010.

[3] Brandão, Tânia Maria Pires. A elite colonial piauiense: família e poder. Teresina: Fundação Cultural Monsenhor Chaves, 1995.

[4] Castello Branco, R.P. A civilização do couro. Teresina: Comepi, 1942.

[5] Celestino, Erasmo. Piauí: mostra a tua cara e diga qual é o teu negócio. In: Santana, R.N. Monteiro de. Apontamentos para a história cultural do Piauí. Teresina (PI): FUNDAPI, 2003.

[6] Nunes, Maria Cecília Silva de Almeida. Revisitando a cultura popular no Piaú: marcas do passado nas manifestações do presente. In: Santana, R.N. Monteiro de. Apontamentos para a história cultural do Piauí. Teresina (PI): Fundapi, 2003.

[7] Silva, Pedro. O folclore no Piauí. Teresina: Fundação Cultural Monsenhor Chaves \Gráfica Mendes, 1988.

[8] Gatti, Bernadete Angelina; Nunes, Muniz Rossa (Org.). Formação de Professores para o Ensino Fundamental: estudo de currículos das licenciaturas em pedagogia, língua portuguesa, matemática e ciências biológicas. São Paulo: Fundação Carlos Chagas/DPE, 2009.

[9] Libâneo, José Carlos. Didática e Docência: formação e trabalho de professores da educação básica. In: Cruz, Giseli Barreto da et al. (Org.). Ensino de Didática: entre recorrentes e urgentes questões. Rio de Janeiro: Editora Quartet, 2014.P. 77-110.

[10] Lüdke, Menga; CRUZ, Giseli Barreto da. Contribuições ao debate sobre a pesquisa do professor da educação básica. Revista Brasileira sobre Formação de Professores. v. 02, n.03, ago-dez, 2010.

[11] Morais, Regis. Cultura brasileira e educação. Campinas (SP): Papirus, 1989.

[12] Moreira, Marco Antônio. O mestrado (profissional) em ensino. Revista Brasileira de Pós-Graduação, Universidade Estadual de Campinas, São Paulo, v.1, n. 1, p.131142, julho, 2004.

[13] Nepomuceno. Cristiane Maria. 0 jeito nordestino de ser globalizado. Tese (Doutorado em Ciências Sociais) Centro de Ciências Humanas, Letras e Artes,Universidade Federal do Rio Grande do Norte, Natal (RN), p 193, 2005.

[14] Nóvoa, Antonio. Professores: imagens do futuro presente. Lisboa: Educa, 2009.

[15] Oliveira, Silvia Andreia Zanelato De Pieri; ALMEIDA, Maria de Lourdes Pinto de. Educação para o mercado x educação para o mundo do trabalho: impasses e contradições. REP - Revista Espaço Pedagógico, v. 16, n. 2, Passo Fundo, p. 155-167, jul./dez. 2009. P. 155-167.

[16] Picos. Secretaria de Planejamento. Plano Pluri Anual (2016-2019). Disponível em: http://www.picos.pi.gov.br/. Acesso em 15 de abril de 2018.

[17] Veiga, Ilma Passos Alencastro. Docência como atividade profissional. In: VEIGA, Ilma Passos Alencastro; D’Avila Cristina (Org.). Profissão docente: novos sentidos, novas perspectivas. Campinas, SP: Papirus, 2008.

[18] Vieira, Maria Alveni Barros. Educação e sociedade picoense: 1850-1930. Teresina: EDUFPI, 2005.

[19] Vieira, Maria Alveni Barros. Relatório Histórico. In: VARÃO, Maria Goreth de Sousa (Org.). Picos: histórias que as famílias contam. Teresina: EDUFPI, 2007.

[20] Vieira, Maria Alveni Barros. et all. Histórias que deveriam ser contadas nas escolas. In: V FIPED, 2013. Parnaíba (PI). Disponível em http://www.editorarealize.com.br/revistas/fiped/trabalhos/Trabalho_Comunicacao_oral_idinscrito_435_9a611ed27 02d149c7a37d9d2061052ff.pdf. Acesso em 10\10\2018.

[21] Vieira, Maria Alveni Barros. et all. História Local no ensino fundamental. Disponível em http://www.editorarealize.com.br/revistas/fiped/trabalhos/Trabalho_Comunicacao_oral_idinscrito_435_9a611ed27 02d149c7a37d9d2061052ff.pdf. Acesso em 10\10\2018. 


\title{
Capítulo 10
}

\section{Experiência da educação contextualizada para a convivência com o semiárido em uma escola do campo do município de Ipiranga do Piaui, Piauí13}

\author{
Bruna Lara Borges da Silva \\ Suzana Gomes Lopes \\ Gardner de Andrade Arrais \\ Tamaris Gimenez Pinheiro
}

Resumo: O Semiárido brasileiro compreende uma área 1,03 milhão de $\mathrm{Km}^{2}$, abrangendo 1.262 municípios de nove estados, sendo ocupado por cerca de 27 milhões de pessoas. Apesar das dificuldades socioeconômicas e ambientais, o Semiárido tem riquezas exuberantes, que refletem nas histórias de povos, suas raízes, aspectos culturais, sociais, econômicos, políticos, subjetividades e religiosidade. Em meio a tudo isso, ergue-se um campo fértil que exige do ato de ensinar uma rica abordagem que contemple toda essa peculiaridade. E é a partir desse olhar singular para essa região tão negligenciada histórica, social, econômica e politicamente que se ergue a Educação Contextualizada para a Convivência com o Semiárido. Assim, este trabalho teve como objetivo analisar as experiências do Projeto de Educação Contextualizada no Semiárido na Escola Municipal Liberato Vieira, localidade Brejo da Fortaleza, Município de Ipiranga do Piauí, a fim de compreender a trajetória e a necessidade da implantação do projeto na referida escola e as contribuições e dificuldades da experiência para a comunidade envolvida. Para obter as informações foram realizadas observações in loco, além de entrevista semiestruturada com gestores e docentes. Foi possível perceber que o trabalho realizado na escola busca a integração com a comunidade, o que foi conseguido por meio da realização de projetos. 0 projeto que alavancou a proposta de Educação Contextualizada na escola foi o "Potencialidade Sócio Econômica do Brejo da Fortaleza", em que se investigou junto à comunidade o que é produzido na região. Foi a partir dele que outros projetos foram idealizados como o da "Horta Pedagógica", "Viveiro de Mudas" e "Água: cuidar hoje para não faltar amanhã". As atividades desenvolvidas nos projetos visam integrar a aprendizagem cotidiano-comunitária dos alunos na contextualização dos conteúdos disciplinares e o envolvimento de todos os atores da comunidade escolar no trabalho educativo foi o aspecto positivo da efetivação da proposta na escola. Assim, o envolvimento da comunidade e o protagonismo dos alunos foram tanto o pontapé inicial como o grande motivador para a continuação do desenvolvimento da proposta na escola. Nessa perspectiva, a indissociabilidade das ações da escola com as necessidades da comunidade e o envolvimento dela e da família dos alunos nas ações é inquestionável e deverá sempre ser considerada caso haja a intenção de implementação de propostas de trabalho como a apresentada nesse estudo.

Palavras-chave: Ensino. Escola do campo. Integração escola-família.

${ }^{13}$ Esse estudo foi fruto do Trabalho de Conclusão de Curso da primeira autora, atualmente graduada em Licenciatura em Educação do Campo, Ciências da Natureza, pela Universidade Federal do Piauí. 


\section{INTRODUÇÃO}

O Semiárido brasileiro se estende por 1,03 milhão de $\mathrm{Km}^{2}$, compreendendo 1.262 municípios de nove estados (Alagoas, Sergipe, Bahia, Rio Grande do Norte, Ceará, Minas Gerais, Paraíba, Pernambuco e Piauí). Neste espaço geográfico vivem cerca de 27 milhões de pessoas (BRASIL, 2017).

As características que definem esse espaço geográfico são: i) precipitação pluviométrica média anual igual ou inferior a $800 \mathrm{~mm}$; ii) índice de aridez de Thorntwaite igual ou inferior a 0,50; iii) percentual diário de déficit hídrico igual ou superior a 60\%, considerando todos os dias do ano (BRASIL, 2017). Apesar de ser considerada a região mais pobre do Brasil, o Semiárido tem riquezas exuberantes, que refletem nas histórias do seu povo, suas raízes, aspectos culturais, sociais, políticos, econômicos, subjetividades e religiosidades.

Em meio a tudo isso, ergue-se um campo fértil que exige do ato de ensinar uma rica abordagem que contemple toda essa peculiaridade. E é a partir desse olhar singular para essa região tão negligenciada histórica, social e politicamente que se ergue a Educação Contextualizada ${ }^{14}$ para o Semiárido, a qual surge para valorizar e afirmar os saberes de sua população no meio em que vivem, trabalhando fragilidades e potencialidades (SENA, 2014). Esse autor esclarece que:

[...] torna-se indispensável a discussão sobre a Educação Contextualizada para a Convivência com o Semiárido. Esta pode ser concebida como uma práxis, um processo elaborativo de conhecimentos teóricos e práticos que tem como princípio a convivência com o território dos sujeitos, o respeito à condição de vida do indivíduo, à realidade local como ponto de partida e de chegada dos conhecimentos diversos, que não a torne fechada em si mesma, pois se opõe ao modelo universalista de educação, não buscando ferramentas para aprisionar o sujeito àquele determinado conhecimento, mas de maneira que o extrapole, que vá além do saber, tornando-se ferramenta fundamental para a emancipação e libertação, ampliando o que já sabe, experimentando o que não conhece. (SENA, 2014, p. 18).

A partir dessa proposta, juntamente com o interesse regional, em torno da urgente necessidade de valorização da região, algumas instituições não-governamentais, escolas e movimentos sociais que desenvolviam ações com fins similares, em 2000, se organizaram para realizar o I Seminário de Educação para a Convivência com o Semiárido Brasileiro (SOUZA, 2010). A ideia do evento foi dialogar sobre as experiências desses atores e dali expandir o movimento pela efetiva constituição da Educação Contextualizada no Semiárido para os vários estados do Nordeste. Esse movimento cresceu e dele se originou a Rede de Educação do Semiárido Brasileiro (RESAB) que, atualmente, reúne instituições governamentais e não governamentais. Segundo Martins (2007, p. 36):

Esta perspectiva de "educação contextualizada" está sendo sustentada em toda a região semiárida, a partir da premissa de que "a educação tem que tocar no chão que pisa", ou seja, a educação não pode se dar ao luxo de flutuar sobre os lugares, sem dialogar com os modos de produção da vida, ou com as configurações e potencialidades ecossistêmicas com que a natureza brinda cada lugar.

Segundo Carvalho (2012), esta proposta, torna-se um guarda-chuva, abrigando todos aqueles que buscam relacionar-se por outra/nova maneira de viver ou ampliar as maneiras de viver e se relacionar com a realidade semiárida. Com isso, as discussões advindas dessa concepção apontam para uma adaptação dos conteúdos escolares ao espaço geográfico, à cultura, à identidade e à especificidade do Semiárido. Adaptação essa baseada na realidade social dos educandos e educandas, que possibilita contextualizar o processo de ensino aprendizagem com a diversidade cultural de cada lugar. É uma proposta de educação pautada no princípio da convivência com as características socioambientais do Semiárido, visando a criação de um novo senso comum, de novos significados do lugar e da vida no lugar, a partir de uma nova leitura do próprio espaço (SILVA, 2002).

Segundo Souza (2010), uma das bases de sustentação da proposta da Educação Contextualizada no

${ }^{14}$ Contextualização é uma palavra derivada do termo "contexto" que significa inter-relação de circunstância que acompanha um fato ou uma situação. Neste caso, contextualizar é integrar em um contexto. Portanto, educação contextualizada é trabalhar o conhecimento sistemático de acordo com a realidade em que o aluno está inserido, considerando sua diversidade cultural, econômico e social, tornando possível o desenvolvimento de suas potencialidades (LIMA, 2014). 
Semiárido é o artigo 1ำ da Lei de Diretrizes e Bases da Educação Nacional (LDB) (Lei No 9.394/96) em que a educação é abordada como processo formativo para além da escola. Segundo essa autora, a referida Lei permitiu que iniciativas diversas situadas em, principalmente, Organizações Não Governamentais (ONG's) e em outros movimentos sociais fossem reconhecidos como espaços educativos que desencadeiam outros modos de intervenção social.

Assim, experiências que ocorriam em diversas partes do país reforçavam que espaços não escolares constituíam cenários relevantes para que os sujeitos (sem escolarização) produzissem, por via de suas práticas diárias, importantes conhecimentos (SOUZA, 2010) e que eles deveriam ser valorizados e levados para dentro dos muros das escolas. Com isso, a Educação Contextualizada no Semiárido é fruto destas experiências. 0 mote era a construção de um discurso diferenciado sobre o desenvolvimento regional e a base da Convivência era destituir a compreensão do desenvolvimento vinculado ao combate às secas, propondo criar formas sustentáveis e apropriadas de lidar com os fenômenos geoclimático-ambientais desta região (SOUZA, 2010).

Para essa última autora, o combate deveria ser contra as desigualdades sociais, pois estas decorriam da cultura política dominadora e das grandes concentrações de renda, de terra e da água, e não do perfil climático. Essas discussões permitiram o acesso a diversas iniciativas, desencadeando uma integração social entre espaços escolares e sociedade, produzindo assim as práticas, podendo então ter acesso aos conhecimentos importantes, fazendo assim uma experiência diferenciada para o seu desenvolvimento.

Assim, pode-se afirmar que a Educação Contextualizada para o Semiárido pressupõe práticas educativas desenvolvidas nas escolas, aproximando o homem à sua realidade, como também a possibilidade de um ensino onde os sujeitos sejam capazes de construir/reconstruir sua história de forma digna, através de diálogos entre educador e educando (LIMA, 2014). Nesse sentido, não é qualquer tipo de educação que vai preparar o sujeito para enfrentar o desafio de construir um Semiárido justo, solidário e sustentável, por isso é preciso pensar uma educação que se constrói no seio da sociedade, tendo a vida e a história do povo como pontos de partida para uma reflexão do mundo (LIMA, 2006).

O desenvolvimento e divulgação de experiências educativas populares e inovadoras, promotoras de emancipação humana, ainda é muito recente (ANDRADE; FERNADES, 2016). Para a Educação Contextualizada no Semiárido não é diferente. Por isso, diante da necessidade de informações que subsidiem as discussões sobre a importância da Educação Contextualizada no Semiárido e como desenvolvê-la na prática, esse estudo objetiva analisar as experiências do Projeto de Educação Contextualizada no Semiárido na Escola Municipal Liberato Vieira (Figura 1), localidade Brejo da Fortaleza, Município de Ipiranga do Piauí, a fim de compreender a trajetória e a necessidade da implantação do projeto na referida escola e as contribuições da experiência para a comunidade envolvida. A instituição adotou o Projeto de Educação Contextualizada no Semiárido desde o ano de 2012 e atende somente a comunidade rural Brejo da Fortaleza.

Figura 1 - Imagem da fachada da Escola Municipal Liberato Vieira, município de Ipiranga do Piauí, Piauí.

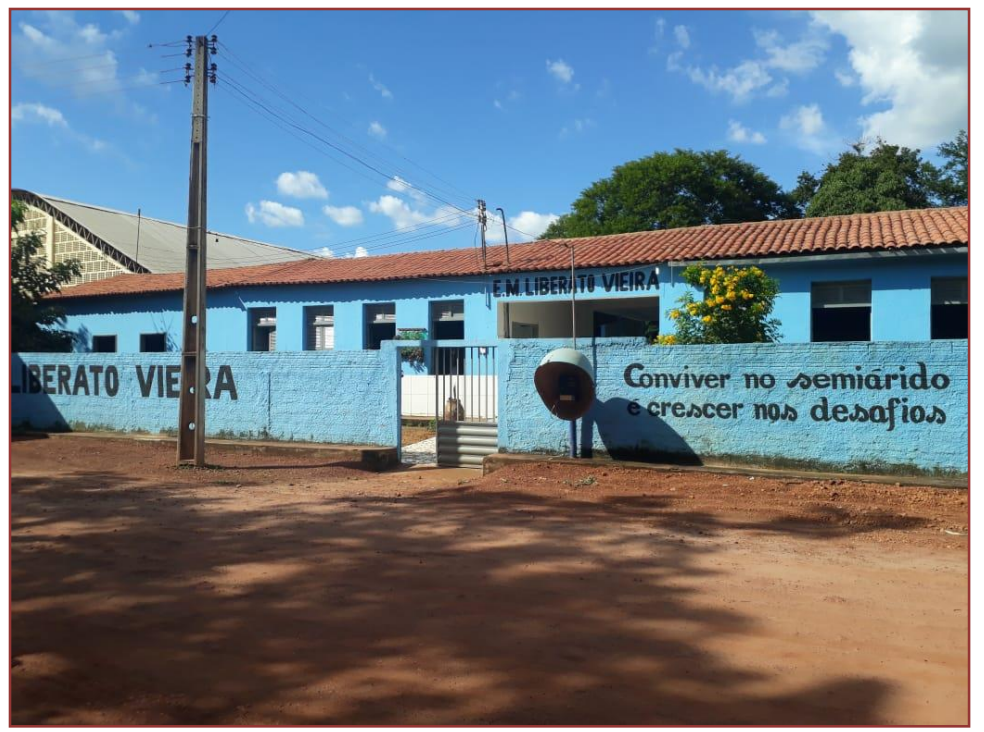

Fonte: MACEDO, F.A.S. (2019). 


\section{METODOLOGIA}

A coleta de dados foi realizada no primeiro semestre de 2018. Para obter as informações foram realizadas observações diretas in loco, além de entrevista semiestruturada com a gestora da escola e com nove docentes, a fim de identificar como foi implantado e está sendo desenvolvido o Projeto de Educação Contextualizada no Semiárido na escola; as práticas pedagógicas adotadas; e o envolvimento e contribuições para a comunidade escolar. As entrevistas foram registradas em áudio para posterior transcrição, textualização e análise qualitativa. Para cada sujeito da pesquisa foi entregue o Termo de Consentimento Livre e Esclarecido e sua identidade foi preservada, sendo eles identificados pelos cargos que desempenham.

\section{RESULTADOS E DISCUSSÃO}

A proposta de realização de Educação Contextualizada no Semiárido na escola se deu a partir de iniciativa do Prof. Elmo de Souza Lima, no ano de 2012. Na época o professor-pesquisador estava desenvolvendo seu trabalho de doutorado na Universidade Federal do Piauí e precisava de uma escola que abraçasse sua pesquisa. Ele entrou em contato com a Secretaria Municipal de Educação de Ipiranga do Piauí e a mesma lhe concedeu a abertura de apresentar seu projeto às escolas para verificar se as mesmas tinham interesse.

O docente então, em um encontro pedagógico promovido pela Secretaria de Educação com os/as diretores/as das escolas do município, realizou a apresentação da proposta. De todos/as os/as presentes somente a diretora da escola pesquisada demonstrou interesse pelo trabalho, pois a mesma acreditava que a comunidade precisava de um projeto como aquele, voltado para a realidade da comunidade, que pudesse trazer as famílias para dentro da escola, colocando a escola à disposição do professor. Segundo a Gestora:

O projeto da escola sobre Educação Contextualizada, não foi uma coisa pensada. Eu não fui buscar. Na verdade, esse projeto veio para nós como um presente pois muitos alunos estavam faltando aulas, desmotivados, não queriam vir para a escola... Eu como sempre conversava com eles o porquê eles faltavam a escola e a respostas eram: "Ah tia! A escola é muito sem graça, prefiro ir pra roça". Então comecei a pesquisar sobre algum tipo de educação que fosse voltado para a comunidade e vi que a Educação Contextualizada era uma boa opção e que ela pudesse despertar nesses alunos o desejo e a vontade deles de estarem na escola. $O$ projeto tem uma metodologia interessante, em que o aluno vai conhecer sua realidade do dia a dia, conhecer de fato o lugar onde mora, e assim, na primeira oportunidade aceitei a proposta da Educação Contextualizada no Semiárido na escola Liberato Vieira (Gestora).

Ao levar a proposta para a escola, todos os professores demonstraram resistência por desconhecerem a temática da Educação Contextualizada, principalmente voltada para o Semiárido, e acreditarem que a diretora havia assumido uma responsabilidade muito grande. Resistiam também pela falta de prática em trabalhar com projetos integradores, pois entendiam a metodologia tradicional de ensino, com a utilização exclusiva do livro didático nas aulas, como a única forma possível de realização do trabalho pedagógico.

Sobre isso, Docente 1 afirmou: "No início eu resisti, não conhecia esse projeto, fiquei com medo de ter que largar o livro didático, onde sou muito apegada, pra gente que já tá com muito tempo nessa mesma metodologia acaba se apegando". Já a Docente 2 afirmou: "Eu confesso que fiquei apavorada, sem saber nem o que falava, pois sabia que era uma grande responsabilidade e que iria ter uma grande reviravolta. Sobre isso a Gestora relembrou que:

No início, houve sim, como tudo que é novo, há uma resistência, eu não diria uma resistência, mas um medo de um projeto tão valioso e uma comunidade tão complicada como o Brejo, mas ao longo do tempo quando elas foram conhecendo a metodologia se apaixonaram e hoje elas são muito gratas por todo o aprendizado que a gente obteve, conheceram a comunidade, conheceram as pessoas. Hoje a gente tem um acesso maior a tudo o que diz respeito a comunidade porque quando a gente conhece tudo fica mais fácil trabalhar. Mas houve sim uma resistência, mas hoje foi superada graças a Deus. (Gestora)

Na concepção de Lima (2014), a resistência dos professores sobre o assunto vai reduzindo na medida em que vão se apropriando coletivamente das categorias teóricas e dos princípios políticos que fundamentam a concepção de Educação do Campo, ao buscar organizar atividades educativas que permitem a vivência 
teórico-prática daquela proposição, com o desenvolvimento de atividades educativas que se constituem como práxis educativa, enquanto síntese das experiências de reflexão crítica em que estão imersos.

Para que isso ocorresse houve, primeiramente, um trabalho de formação de professores fundamentado nos pressupostos políticos e socioculturais que orientavam os Círculos de Cultura. Para Freire (1992, p. 155):

Os Círculos de Cultura eram espaços em que dialogicamente se ensinava e se aprendia. Em que se conhecia em lugar de se fazer transferência de conhecimento. Em que se produzia conhecimento em lugar da justaposição ou da superposição de conhecimento feitas pelo educador a ou sobre o educando. Em que se construíam novas hipóteses de leitura do mundo.

Então foram desenvolvidas reuniões com a comunidade escolar, pais e alunos (Figura 1). A diretora da escola propôs um encontro, no qual o professor Elmo Lima apresentaria o seu trabalho e foi a partir daí que os diálogos foram instituídos na comunidade Brejo da Fortaleza para a construção coletiva do projeto. Foi discutido com os docentes um breve diagnóstico da comunidade, o que possibilitou o conhecimento e a compreensão crítica dos aspectos sociais, históricos, políticos, econômicos e culturais, identificando as potencialidades e os limites de construção de uma política de desenvolvimento sustentável, compreendendo os aspectos históricos e culturais que influenciaram a formação política e cultural do povo do Semiárido.

Figura 2 - Imagem da reunião para a apresentação da proposta de implantação da Educação Contextualizada para a Convivência com o Semiárido na Escola Municipal Liberato Vieira, município de Ipiranga do Piauí, Piauí, realizada pelo Prof. Elmo de Souza Lima no ano de 2012.

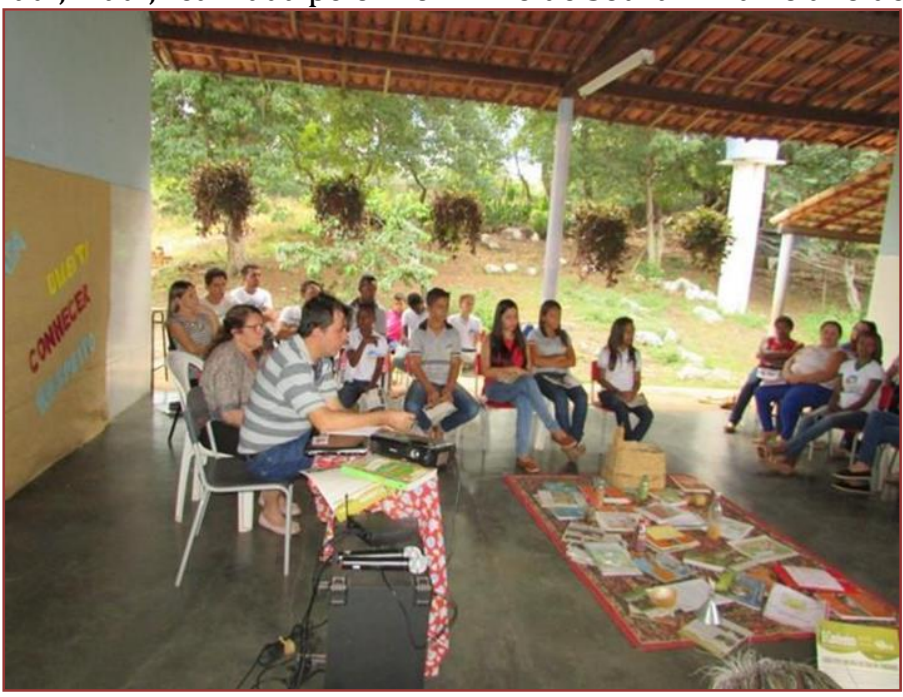

Fonte: RIBEIRO, R.A.P. (2012).

Na concepção de Lima (2008), os docentes necessitam ser capacitados para o desenvolvimento de processos educativos que tenham a problematização, a reflexão crítica e a investigação como eixos político-pedagógicos norteadores de sua ação educativa. Os processos foram desenvolvidos e construídos de modo que os professores e alunos, coletivamente, discutissem sobre os aspectos sociais, políticos e econômicos que perpassam suas vidas.

As formações constituíram-se de "Rodas de diálogos", favorecendo a reflexão crítica dos sujeitos acerca do contexto sócio histórico e cultural da comunidade. Para Lima (2014), essa formação visou a produção coletiva de conhecimentos que permitissem a reorientação da proposta curricular da escola na perspectiva do currículo contextualizado. A formação foi desenvolvida em 14 encontros distribuídos em dois anos, de forma bimestral, com professores, comunidade e alunos. Essa formação permitiu identificar elementos na própria escola que serviriam de suporte para os projetos a serem trabalhados, como a cisterna, por exemplo, que havia sido construída em 2009, e não tinha finalidade para a instituição ou a comunidade. A partir dessas discussões e provocações, os atores envolvidos na proposta constataram que podiam trabalhar projetos voltados para a realidade da comunidade, contextualizando problemas locais e suas potencialidades ali presentes, beneficiando a mesma. 
O projeto que alavancou a Educação Contextualizada para a Convivência com o Semiárido na escola foi o projeto piloto "Potencialidade Sócio Econômica do Brejo da Fortaleza", em que se investigou junto à comunidade tudo o que é produzido na região e, foi a partir dele que todos os outros projetos foram idealizados.

Um dos projetos desenvolvidos citados como o de maior relevância foi a atividade de iniciação da proposta de contextualização na escola: a "Horta Pedagógica", cujo objetivo foi a construção de um espaço que funcionasse como "laboratório", em que os professores pudessem levar os alunos para uma aula contextualizada aprendendo a teoria na prática, comparando o que está na realidade com o livro (Figura 2). Para a construção da horta na escola houve o envolvimento dos alunos, professores e alguns pais. As etapas de desenvolvimento da horta começaram pela limpeza do local e depois a construção dos canteiros e plantação das sementes. Como a escola não tinha materiais, como enxadas, pás, estrumes e sementes, para a instalação dela contou-se com o apoio da comunidade.

Figura 3 - Projeto "Horta Pedagógica” desenvolvido na Escola Municipal Liberato Vieira, localizada no Povoado Brejo da Fortaleza, município de Ipiranga do Piauí, Piauí. A: Alunos em uma aula na horta; B: Imagem geral da horta com seus canteiros.

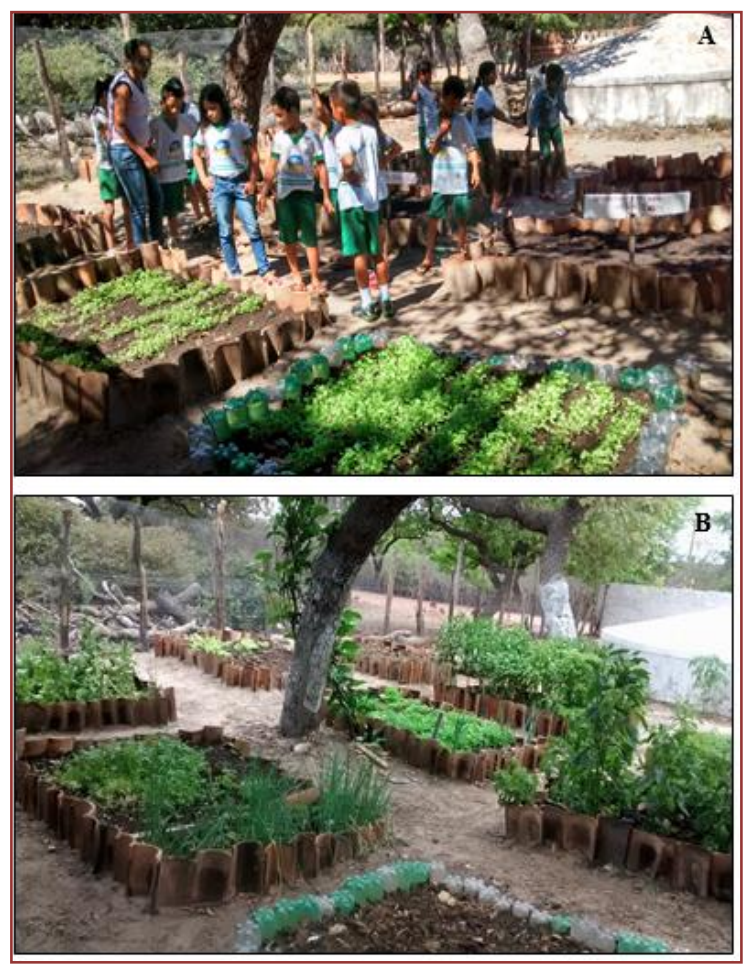

Fonte: RIBEIRO, R.A.P. (2013).

A realização da horta proporcionou aos alunos conhecimentos que transpuseram os muros da escola e chegaram até suas casas, pois foram aplicados em seus quintais, como o que ocorreu com um dos alunos participantes, de apenas 13 anos, que hoje é referência na sua região em produção de hortaliças a partir do que vivenciou e aprendeu com o projeto. Primeiramente a produção tinha o objetivo de produzir para o consumo familiar, mas o sucesso de seu trabalho foi tão grande que hoje aumentou a renda da família com a venda do excedente para povoados vizinhos.

A gestora relembrou que um dia esse estudante lhe falou: "Tia, quando fizeram a cisterna na minha casa comecei a tentar fazer uma horta, com o material que recebemos da escola e com o que já aprendi aqui, mas não deram certo" e acrescentou que:

Foi quando eu pensei e entreguei uma cartilha sobre o manejo da água, ele seguiu o passo a passo e, tudo que ele não entendia, sempre me procurava para tirar suas dúvidas, e assim ele fez um cultivo de tomate, cheiro verde, pimentão, pimentinha de cheiro e pepino utilizando a irrigação alternativa do canteiro econômico. (Gestora) 
O outro projeto desenvolvido na escola partiu das discussões sobre a necessidade dos professores em se trabalhar Ciências de maneira contextualizada e então elaboraram um projeto com as plantas nativas: "Projeto de Viveiro de Mudas" (Figura 3). Ele objetivava o estudo das plantas nativas da região visando a preservação das mesmas. Para o seu desenvolvimento contou-se com saídas de campo para reconhecimento das espécies vegetais e coleta de sementes para o plantio na escola, sempre havendo a associação dos conteúdos com o conhecimento prévio dos alunos. Um dos objetivos específicos desse projeto era fazer a doação das mudas para a comunidade, para que essa fizesse o resgate dessas espécies, podendo recuperar aquelas que já estavam em risco de extinção. Segundo a Gestora:

Como o projeto teve muita repercussão, a comunidade ajudou bastante também. Foi a partir desse projeto que se deu a criação do banco de sementes crioulas, sementes essas que são naturais, sem nenhum tipo de modificação genética e esse banco serve tanto para o estudo em si e para, mais na frente, se os agricultores precisarem dessas sementes, eles terem acesso. (Gestora)

Um dos entusiastas do projeto de sementes crioulas também foi o discente citado acima pela Gestora que, além do canteiro, faz a multiplicação dessas sementes para manutenção do patrimônio genético da comunidade. Como ele, muitas outras famílias têm valorizado essa prática de conservação das sementes crioulas.

Figura 4 - Projeto "Viveiro de mudas" desenvolvido na Escola Municipal Liberato Vieira, localizada no Povoado Brejo da Fortaleza, município de Ipiranga do Piauí, Piauí. A: Alunos preparando o terreno para instalação do viveiro; B: Alunos da escola recebendo as mudas para plantio em suas casas após atividade no viveiro.

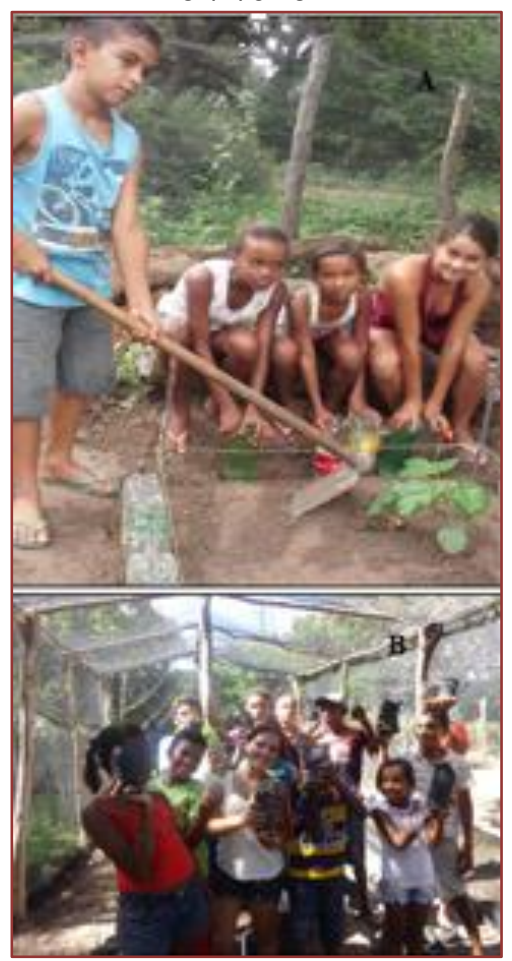

Fonte: RIBEIRO, R.A.P. (2013).

Outro projeto trabalhado na escola, destacado pelos entrevistados, foi o relacionado às nascentes das fontes de água da comunidade que possui como tema "Água: cuidar hoje para não faltar amanhã". 0 objetivo do mesmo era realizar a revitalização dessas nascentes por meio do reconhecimento e limpeza desses locais. Para isso, os alunos saíram da escola e foram à campo, acompanhados pelos professores. A maioria das aulas de Ciências foram realizadas nesse contexto.

Com isso posto, percebeu-se que a Escola Municipal Liberato Vieira busca desenvolver práticas educativas contextualizadas num processo pedagógico que envolve a participação da comunidade na busca de alternativas para os problemas locais. Neste sentido, a escola desenvolve ações educativas a partir de três instrumentos pedagógicos: horta pedagógica escolar, viveiro de mudas e banco de sementes crioulas. E em 
mais processos de integração de atividades escolares e outros processos de formação extraclasse, tais como os intercâmbios e as oficinas técnicas sobre os temas ligados a agroecologia. Como fruto disso, estão os resultados sociais que interferem positivamente na dimensão ecológica e ambiental da comunidade. Para a Gestora:

A diferença dessa forma de educação é a mudança que gera nas crianças $e$ adolescentes, com envolvimento da família no aprendizado, no cuidado como o meio ambiente. É essa educação que queremos, uma educação que incentiva a convivência com o Semiárido gerando melhor alimentação e uma economia gerada do trabalho. (Gestora)

As atividades desenvolvidas nos projetos visam integrar a aprendizagem cotidiano-comunitária dos alunos na contextualização dos conteúdos disciplinares. Eles têm por finalidade motivar os alunos a pensarem a comunidade na comunidade, conhecendo melhor a realidade; trabalhando suas histórias e seu ambiente sociocultural e ambiental. Para a Gestora:

A escola é o lugar onde se encontra a descoberta do fazer-aprender-fazer. É nesse contexto que os alunos, após uma aula prática contextualizada com a sua realidade, fazem com que o mesmo sistematize os conhecimentos adquiridos. (Gestora)

Essas estratégias metodológicas usadas no processo de ensino-aprendizagem na escola, que priorizam o protagonismo do aluno, a prática, incentivam seu interesse, seu envolvimento e desenvolvem a vida na região, são instrumentos de suma importância no processo educacional. Para Martins (2007), a educação contextualizada na escola baseia-se na compreensão de uma educação que considere o contexto como o lugar onde se relacionam ecologias que dizem respeito à cultura, à linguagem, às formas de comunicação e às representações das subjetividades humanas, e não apenas ao que é visivelmente concreto e palpável.

Quando os pesquisados foram questionados sobre os aspectos positivos da efetivação da contextualização na escola, eles apontaram que a conquista mais significativa da proposta foi (e é) o envolvimento de todos os atores da comunidade escolar no trabalho educativo, pois as práticas foram importantes não apenas para os alunos, mas para todos da comunidade, que compartilham seus saberes.

A escola encontra-se a todo momento em processo de aprimoramento de sua prática educacional, a fim de criar um ambiente favorável ao aprendizado contínuo e transformador, incentivado pela pesquisa e pelo desenvolvimento das potencialidades, para a formação do cidadão solidário, ativo socialmente, sujeito de sua história e de seu tempo. Com isso, foi possível constatar que o termo "Contextualização com o Semiárido" é compreendido na sua essência pelos sujeitos da pesquisa, demonstrando que a Escola Municipal Liberato Vieira desenvolve um trabalho voltado para a convivência com o Semiárido, que permite a implementação das atividades pedagógicas articuladas com as necessidades e os desejos dos povos do campo, levando em consideração as potencialidades e fragilidades desse ambiente.

\section{CONSIDERAÇÕES FINAIS}

Constatamos que as práticas pedagógicas desenvolvidas na Escola, voltadas para a convivência com o Semiárido, contribuem positivamente para a construção de um novo cenário em que se concebe o Semiárido enquanto espaço de construção de novas relações de convivência entre os seres humanos e a natureza, com base na sustentabilidade ambiental, e combinando a qualidade de vida das famílias camponesas com o incentivo às atividades econômicas e ecológicas.

Esta pesquisa proporcionou o entendimento de como ocorreu a construção coletiva da Educação Contextualizada em uma escola do Município de Ipiranga do Piauí, possibilitando o conhecimento e a compreensão dos aspectos sociais, históricos, políticos, econômicos e culturais que levaram à sua implementação, identificando as potencialidades do trabalho para o desenvolvimento sustentável no Semiárido.

A reflexão sobre as práticas educativas desenvolvidas na escola permitiu identificar também os desafios enfrentados e benefícios conseguidos pela instituição pesquisada, além de, principalmente, reforçar a importância delas estarem relacionadas às demandas levantadas pela comunidade, demandas estas que permitiram criar estratégias didático-pedagógicas que fomentaram e fomentam a compreensão crítica do contexto em que os sujeitos das ações estão envolvidos. 
Pode-se notar também que o envolvimento da comunidade e o protagonismo dos alunos foram tanto o pontapé inicial como o grande motivador para a continuação do desenvolvimento da proposta na escola. Nessa perspectiva, a indissociabilidade das ações da escola com as necessidades da comunidade e o envolvimento dela e da família dos alunos nas ações é inquestionável e deverá sempre ser considerada caso haja a intenção de implementação de propostas de trabalho como a apresentada nesse estudo.

\section{AGRADECIMENTOS}

Os autores agradecem a todos os servidores e alunos da Escola Municipal Liberato Vieira em nome da Diretora, Sra. Reginalda Alves Pereira Ribeiro, que gentilmente abriu os portões da instituição, permitindo a realização da pesquisa e, consequentemente, a concretização de uma importante etapa da formação da primeira autora. Além disso, a diretora não mediu esforços para fornecer todas as informações necessárias e, com muita boa vontade, sempre esteve disponível para sanar qualquer dúvida. Agradecem também ao Prof. Elmo de Souza Lima por todo auxílio prestado para a elaboração do trabalho.

\section{REFERÊNCIAS}

[1] Andrade. J S.; Fernades. S.A.S. A importância da educação contextualizada para o desenvolvimento do Semiárido, São Paulo: USP, 2016.

[2] Brasil. Delimitação do Semiárido mantém formação atual e inclui 54 novos municípios. Brasília: Ministério da Integração Nacional. 2017. Disponível em <http://www.integracao.gov.br/area-de-imprensa/todas-asnoticias//asset_publisher/YEkzzDUSRvZi/content/delimitacao-do-semiarido-mantem-formacao-atual-e-inclui54novosmunicipios/pop_up?_101_Instance_YEkzzDUSRvZi_viewMode=print\&_101_Instance_YEkzzDUSRvZi_language Id=pt_BR>. Acesso em: 08 jan. 2019.

[3] Carvalho, L.D. Os saberes tecidos no contexto: a vertente educativa da convivência com o Semiárido fundamentando novas práticas e metodologias pautadas na contextualização. In: Seminário de Educação do Campo e Contemporaneidade, 3., 2012, Salvador, Anais...Salvador, 2012.

[4] Freire, P. Pedagogia da Esperança: um reencontro com a Pedagogia do Oprimido. Rio de Janeiro: Paz e Terra, 1992.

[5] Lima, E.S. Educação Contextualizada no Semiárido: Construindo Caminhos para Formação de Sujeitos Críticos e Autônomos. 2006. 88f. Monografia (Especialização em Docência do Ensino Superior). Coordenação de Pósgraduação e Pesquisa da Faculdade Santo Agostinho. Teresina, 2006.

[6] Lima, E.S. Formação de Professores no Semiárido: Valorizando Experiências, Reconstruindo Valores e Tecendo Sonhos, 2008.

[7] Lima, E.S. Currículo das escolas do campo: perspectivas de rupturas e inovação. In: Lima, E.S.; Silva, A.M. Diálogos sobre Educação do Campo. 2. ed. Teresina: Edufpi, 2014.

[8] Martins, J.S. Proposta Político Pedagógica para as Escolas Municipais de Uauá. Petrolina: Gráfica Franciscana, 2007.

[9] Sena, R.R.O. O livro didático em questão: um olhar a partir da perspectiva da Educação Contextualizada. In: Cunha, B.A.; Santos, A.P.S.; Perez-Martin, A.M. (Org.). Educação contextualizada para a convivência com o Semiárido brasileiro: debates atuais e estudos de caso. Campina Grande: INSA, 2014, p. 14 - 33.

[10] Silva, A.P.G. O elogio da convivência e suas pedagogias subterrâneas no Semiárido brasileiro. 2002, Tese (Doutorado em Educação) - Universidade Federal do Rio Grande do Sul, Porto Alegre, 2002.

[11] Souza, I.P.F. A Gestão da Educação Contextualizada no Semiárido: indagações de um processo. 138 f. 2010. Dissertação (Mestrado) - Faculdade de Educação, Universidade Federal da Bahia, Salvador, 2010. 


\section{Capítulo 11}

Projeto Prospera Caatinga: Cartilha ambiental e o recaatingamento

\section{Ithany Felipe Alcântara da Silva \\ Cláudio Roberto Meira de Oliveira}

Resumo: A pesquisa a seguir nos permitir evidenciar algumas causas e as consequências da desertificação no nosso território que sempre sofreu com a seca, o território está localizado no Centro Norte Baiano e ocupa uma área de $26.730 \mathrm{~km} 2$, assim podemos caracterizar alguns pontos nos quais nós somos os agentes causadores da desertificação em todo o território de Irecê. Com tais ações como as queimadas e retiradas desordenadas das plantas dos solos e margens de rios e minadouros, e das águas do subsolo, o trabalho traz com ênfase o recaatingamento, e suas soluções, onde a comunidade juntamente com as escolas do estado estarão recebendo palestras e atividades voltada a educação ambiental, que ao decorrer desse processo será distribuído aos mesmos mudas de plantas para que possam fazer a reposição das áreas afetas, juntamente com a comunidade o próprio projeto estará com uma campanha de conscientização da reutilização dos sacos plásticos, para que sejam reutilizados com as confecções das mudas. 0 trabalho juntamente com a sua ênfase traz como ponto principal a conscientização de cada cidadão do território de Irecê.

Palavras-chave: Desertificação; Território de Identidade de Irecê; Educação ambiental. 


\section{INTRODUÇÃO}

O Território de Identidade de Irecê (TII) localiza-se no sertão da Bahia, no Centro Norte Baiano, com uma área de $26.730 \mathrm{~km}^{2}$, equivalente a 4,6\% da superfície do Estado sendo constituído por 20 munícipios: Central, Gentio do Ouro, Itaguaçu da Bahia, João Dourado, Xique-Xique, América Dourada, Barra do Mendes, Barro Alto, Cafarnaum, Canarana, Ibipeba, Ibititá, Ipupiara, Irecê, Jussara, Lapão, Mulungu do Morro, Presidente Dutra, São Gabriel e Uibai. A população é estimada em 400.063 habitantes. Ocupa a zona fisiográfica da Chapada Diamantina Setentrional e é caracterizada por duas feições morfológicas distintas: os chapadões metassedimentares do grupo Chapada Diamantina e o Platô calcário do grupo bambuí. 0 TII ficou conhecido pela sua potencialidade nas produções agrícolas de mamona, milho e feijão décadas atrás e até então temos "a própria Irecê reconhecida como a capital do feijão". 0 território está localizado na região semiárida do Nordeste e sempre teve problemas com a seca, por outro lado, o subsolo sempre foi rico em águas subterrâneas, mas há alguns anos a situação vem se agravando com a retirada das águas por meio dos poços artesianos para uso na agricultura. E com mais essa condicionante, o processo de desertificação tem se acentuado e o nosso território tem perdido muito, não só nas questões hídricas mais também na questão da destruição da flora e redução da fauna. A seca é um fenômeno natural que muitas vezes está associado a degradação e posterior desertificação do solo, principalmente nas regiões subúmidas áridas, semiáridas e áridas, sendo o resultado, muitas vezes combinado, das variações climáticas e das atividades humanas (OLIVEIRA \& OLIVEIRA, 2016). Nesse sentido, o processo de desertificação tem se acentuado em diferentes partes do território e, por isso a importância de projetos que tragam essa questão à tona e evidencie uma possível solução com a realização de campanhas nas escolas, associações e comunidades para apresentar os problemas da desertificação e as possíveis soluções.

\section{OBJETIVO}

O projeto "Próspera Caatinga" tem como objetivo apresentar a toda comunidade acadêmica e territorial os impactos causados pela desertificação no Território de Identidade de Irecê (TII), suas causas e possíveis soluções. Por meio de palestras e atividades voltadas ao desenvolvimento da Educação Ambiental, estaremos buscando despertar a sensibilidade e o senso crítico da população para refletir sobre o assunto. Durante as visitas aos colégios estaduais de cada um dos 20 municípios que compõem o TII, serão realizadas oficinas e também a distribuição de mudas de espécies nativas e exóticas da Caatinga.

\section{MATERIAL E MÉTODOS}

No projeto em questão está sendo usada a metodologia de campo que corresponde a coleta de dados, tais como entrevistas, observações diretas, questionários, documentação analises e interpretações de fatos e fenômenos dentro dos cenários e ambientes de vivência dos objetos estudados, é uma pesquisa importante, pois define os objetivos da pesquisa. Nela cabe ao pesquisador realizar a observação minuciosa do objeto em estudo levando em consideração o seu comportamento em seu habitat natural.

O tipo de pesquisa usada no projeto é a descritiva, que é usada pelos pesquisadores para descrever as características de uma população, um fenômeno ou experiência para o estudo realizado. (Prodanov, Cleber Cristiano 2013, p. 126).

Na primeira etapa, buscaremos desenvolver uma metodologia de parcerias, aonde contaremos com a colaboração do Núcleo Territorial de Educação de Irecê "NTE-01" SEC-BA que disponibilizara 29 colégios estaduais, da parceria com diferentes projetos estaduais existentes como o "COM-VIDA" e "JUVENTUDE EM AÇÃO". Com esse apoio poderemos aprofundar os estudos sobre o semiárido dentro dos colégios participantes e a parti de o projeto "Com Vida" fomentar a criação de um conselho ambiental para fiscalizar e desenvolver atividades para Educação Ambiental dentro das UEE do território. Com o projeto "Juventude em Ação" serão desenvolvidas conjuntamente atividades voltadas ao meio ambiente como as diferentes formas de preservação e sensibilização em relação aos diferentes problemas climáticos. Assim, os projetos pensados para acontecer além dos muros escolares. Na segunda etapa do projeto começaremos a pesquisa de campo que consistira em visitas aos municípios e comunidades atingidos pela desertificação. Durante essas visitas será realizada uma pesquisa de campo com a aplicação de questionário para identificar as necessidades de cada área e dar início, a parti das informações coletadas a confecção de uma cartilha ambiental, de panfletos infirmativos e outros documentos que tratam do assunto desertificação. Na terceira etapa será ministrada uma oficina aberta à comunidade em uma escola estadual onde serão distribuídas mudas de plantas nativas da Caatinga e plantas "urbanas" para sombra e frutíferas para começar o processo de arborização das cidades e campo, neste último buscando-se o recaatingamento. Para 
alcançarmos essa finalidade, iniciaremos com a produção e distribuição de mudas, sendo que os recipientes serão oriundos de campanhas para a coleta de sacos de arroz, feijão entre outros de um e dois quilos (1 kg e $2 \mathrm{~kg}$ ) evitando-se assim o gasto de recursos financeiros e o reaproveitamento de materiais que seriam normalmente descartados na natureza ou jogados em lixões, além de contar com a doação de sementes e mudas feitas por toda a comunidade do território e órgãos governamentais 0 próximo material que seria a realização das oficinas nas escolas estaduais e ao termino destas seriam feitas a distribuição de mudas para que os presentes possam fazer o processo de recaatingamento na comunidade onde residem.

O quadro 1 apresenta as perspectivas e etapas para a realização do projeto de forma resumida.

O quadro 1 Perspectivas de datas para realização das etapas.

\begin{tabular}{|c|c|}
\hline Datas & Etapas \\
\hline $\begin{array}{c}\text { 26 de fevereiro a 04 de } \\
\text { março }\end{array}$ & $1^{\circ}$ etapa contato com os secretario e entidades de apoio \\
\hline $\begin{array}{c}11 \text { de março a 08 de } \\
\text { abril }\end{array}$ & $2^{\circ}$ etapa pesquisa e confecção do material \\
\hline $\begin{array}{c}15 \text { a } 30 \text { de abril } \\
01 \text { a } 06 \text { de maio }\end{array}$ & $\begin{array}{c}3^{\circ} \text { etapa classificação de sementes e mudas para distribuição } \\
\text { e definir municípios e colégios para realização do projeto }\end{array}$ \\
\hline
\end{tabular}

Figura 1: Localização do Território de Identidade de Irecê

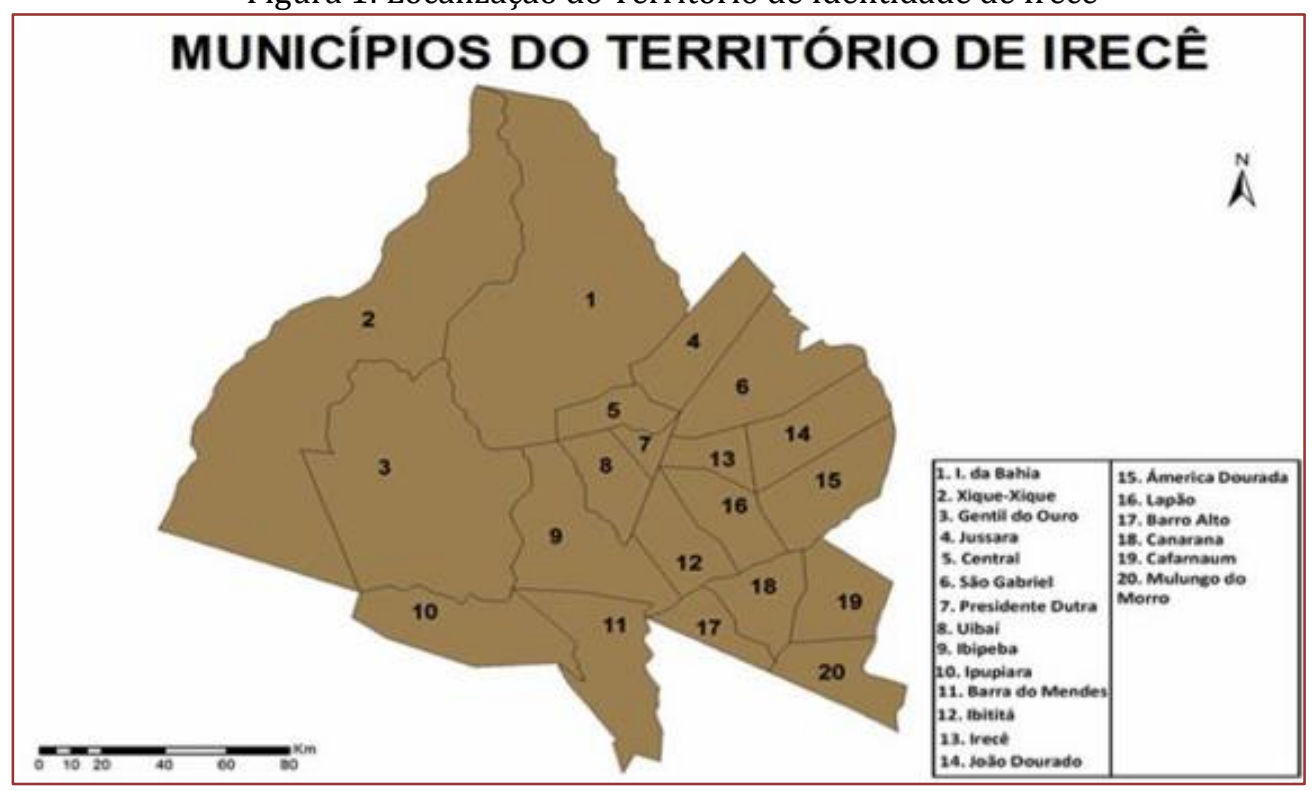

Resultados e Discussão

\section{RESULTADOS E DISCUSSÃo}

Durante a elaboração desse projeto vimos as maiores causas da desertificação do nosso território é o desmatamento desordenado, uso inadequado dos nossos solos, o excesso de agrotóxicos e as queimadas regulares e principalmente, a não reposição das árvores nativas do nosso semiárido, plantas essas que sobrevivem a toda a seca e conseguem armazenar água durante todo o período sem chuva. Um outro fator que influencia não só a desertificação, mas também leva a morte de várias nascentes é a regular retirada 
das plantas das margens dos rios, fato muito comum neste território comprometendo assim o fluxo constante das fontes e minadouros de água. Dentre as questões abordadas destacam-se as vinculações entre os processos de degradação e desertificação com os padrões da territorialização desigual do desenvolvimento, associados às políticas de modernização do setor agropecuário em moldes conservadores que marcaram o Nordeste Semiárido (MACEDO, 2010).

Ao conversar com alguns agricultores e moradores percebemos em suas falas que os próprios contribuíram com o processo de desertificação do território realizando um manejo errôneo e arcaico das suas terra que consistia em desmatar toda ou uma grande área da propriedade para realizar a monocultura os específicos moradores dessa área fala muito sobre esse processo de desertificação que se aumenta cada vez mais porem não tomam nem um iniciativa enquanto a isso, a área de caatinga nessas propriedades são pouca e mesmo assim não se faz nada para preserva.

\section{CONCLUSÕES}

Por fim, para combater a desertificação em nosso território devemos nos enxergar como agentes capazes de reduzir e até combater esse terrível processo que nos atinge com uma frequência cada vez maior. A nossa não ação diária, poderá antecipar e aumentar os problemas ambientais causados pela desertificação. Cumprindo-se essas etapas três etapas, esperamos poder contribuir com os projetos "Com vida e Juventude em Ação" visando assim colaborar com a ação ambiental neste território de identidade da Bahia. Finalmente, esperamos que as cartilhas e informações obtidas pela pesquisa sirvam para sensibilizar a comunidade e mostrar os impactos ambientais neste território que é um dos mais importantes da Bahia e que possam refletir sobre suas ações individuais.

\section{REFERÊNCIAS}

[1] Brasil. Ministério do Desenvolvimento Agrário. Disponível em:<http://sit.mda.gov.br/download/ptdrs/ptdrs_qua_territorio050.pdf> acesso:29 de agosto de 2018 ás 23:00

[2] Ibge. Censo Demografico 2015. Disponível em www.ibge.gov.br

[3] Macêdo, L. R. de L. Dinâmica Socioprodutiva de Territórios Susceptíveis à Desertificação no Estado da Bahia: o caso de Irecê. Dissertação de Mestrado. Universidade Estadual de Feira de Santana - UEFS. 2010. 176p

[4] Nepomuceno, M. Q.; Lobão, J. S. B.; VALE, R. M. C. Estudo da fragmentação da vegetação como indicador da susceptibilidade a desertificação no polo de Irecê - BA.

[5] Disponível em: <http://www.xvisemic.esy.es/arquivos/sessao-vi/maurilio- queirosnepomuceno.pdf>. Acessado em: 03 de out. de 2016.

[6] Oliveira, C. R. M de; Oliveira, D. dos S. C. de. Educação e Percepção Ambiental: a Desertificação no Território do Sertão Produtivo da Bahia. In.: Congresso Internacional da Diversidade do Semiárido. 2016, Campina Grande, PB. Anais... Campina Grande: Realize, 2016.

[7] Prodanov, Cleber Cristiano. Metodologia do trabalho científico [recurso eletrônico]: métodos e técnicas da pesquisa e do trabalho acadêmico / Cleber Cristiano Prodanov, Ernani Cesar de Freitas. 2a ed. - Novo Hamburgo: Feevale, 2013. 


\section{Capítulo 12}

Olimpíadas científicas: A informática como instrumento de melhoria de qualidade de vida $e$ de aprendizagem

Williams Alves Xavier

Izaias Romario Soares do Nascimento

Márcia Verônica Costa Miranda

Resumo: Competições escolares são capazes de potencializar habilidades dos participantes envolvidos, como também elevar a autoestima e a vontade de aprender o conteúdo da temática e outros benefícios educativos. 0 objetivo do presente trabalho é apresentar as ações executadas no projeto "Olímpiada Paraibana de Informática-Sede Areia-PB", no auxílio e desenvolvimento dos alunos do Ensino Fundamental do município de Areia - PB. Em 2017, foi realizada a quinta edição da Olimpíada Paraibana de Informática (OPI) e a quarta edição da Olimpíada Brasileira de Informática (OBI), cujos objetivos são despertar nos alunos o interesse na área da Informática, Matemática e pela Ciência, em geral, com o propósito de prepará-los para competições nacionais e internacionais, contribuindo para a melhoria de aprendizagem e desempenho em sala de aula. Estas atividades foram executadas com ajuda da equipe de Informática do Centro de Ciências Agrárias da Universidade Federal da Paraíba (CCA-UFPB), com ministração de cursos preparatórios e aulas nas zonas urbana e rural da região. 0 número de alunos que participaram do projeto vem aumentando no decorrer dos anos, evidenciando o seu caráter inclusivo e social. Desde a primeira edição, os alunos treinados pela equipe do projeto, vêm ocupando lugares de destaque na competição em níveis estadual e nacional. Professores da rede de ensino da região afirmam que esses alunos vêm melhorando o desempenho nas diversas disciplinas e se sentem valorizados na comunidade. Hoje, o projeto já é considerado inclusivo e multidisciplinar, uma vez que trabalha com alunos em condições de vulnerabilidade social, procurando incentivá-los e motivá-los em seus estudos. Ademais, contribui com a qualidade no ensino, já que os alunos têm melhorado o desempenho na sala de aula, bem como o desenvolvimento local, uma vez que vislumbram um melhor aproveitamento do aprendizado em suas comunidades.

Palavras-Chave: Educação, Informática, Inclusão, Olimpíadas Científicas. 


\section{INTRODUÇÃO}

Apesar da universalização do acesso ao ensino básico no Brasil, mostra-se necessária a utilização de artifícios que estimulem o aluno a uma melhor compreensão do conteúdo ministrado em sala de aula (KLEIN, 2007).

A aprendizagem pode acontecer em situações informais de ensino, nas quais o sujeito que aprende está submerso em um ambiente cultural informador. Este processo pode ser planejado com ações que visem a aprendizagem, como é o caso daquelas organizadas no ambiente escolar. Neste sentido, podem ser executadas várias atividades extracurriculares que auxiliem o aluno fora da rotina escolar, afastando-os do ócio e das ruas. Atualmente, as olimpíadas científicas vêm tomando destaque no meio acadêmico, sendo utilizada por diversas áreas de conhecimento como ferramenta de aprendizado e inclusão.

Em diversos países, as competições escolares são realizadas para alcance de uma educação de excelência (NASCIMENTO et al., 2007). Essas atividades estimulam o aprofundamento nos conhecimentos e nos estudos, pois propõe um desafio construtivo, promovendo o desenvolvimento de formas de aprendizado adequadas para a idade e nível dos alunos. Geralmente, essas olimpíadas são organizadas em áreas específicas do conhecimento (matemática, física, informática, etc.), como também de acordo com o nível educacional dos participantes (REZENDE \& OSTERMANN, 2012).

As olimpíadas científicas são atividades extracurriculares realizadas em vários países para se atingir uma série de objetivos intelectuais, afetivos e sociais. ALVES (2006) comenta os dois tipos de competições escolares: as que exploram o rendimento físico em atividades esportivas e as que envolvem o conhecimento trabalhado e refinado em sala de aula, como as olimpíadas científicas. Essas, apesar de culminarem em atividades extracurriculares, têm ações que acontecem na sala de aula e que, de uma forma ou de outra, afetam a organização escolar, auxiliando os professores na melhoria do aprendizado e desempenho escolares.

As competições nas olimpíadas científicas podem ser realizadas individual ou coletivamente. Nas individuais, é necessário que o competidor obtenha a maior pontuação entre os demais, no conjunto de tarefas realizadas. Já nas coletivas, os competidores atuam de forma colaborativa, de modo que o grupo seja vitorioso.

Robinson (2003), coordenador das olimpíadas científicas do Ensino Médio de Nova Iorque, também é um incentivador desse tipo de competição. Ele afirma que as olimpíadas científicas desafiam os estudantes com problemas de Ciências, incentivando a criatividade, engenhosidade e perícia em uma disciplina, diversificando as formas de aprendizagem.

ROBINSON (2003), FERNANDES \& GALIAZZI (2007) e CORRÊA et al (2009) apontam, em seus trabalhos, as olimpíadas científicas como uma atividade educacional vantajosa, que vai além da simples competição. Essas atividades despertam a motivação e, como consequência, aumentam o engajamento dos estudantes para com os conteúdos escolares.

LOPES (2001), ao se referir às Olimpíadas de Informática, ressalta os objetivos pedagógicos alcançados por esse tipo de atividade extracurricular, que são:

i) O aumento da atenção e da concentração - a falta de concentração é ocasionada, muitas vezes, pelo desinteresse em uma determinada atividade proposta em sala de aula;

ii) 0 desenvolvimento da autonomia - algumas competições permitem o desenvolvimento do estudante ao possibilitar que ele tome decisões; e

iii) Redução da descrença na capacidade de realização - ao ser colocado em um desafio, o estudante tem a oportunidade de desenvolver sua capacidade criativa, acreditar em si mesmo, executar uma ação e atingir um determinado objetivo.

Essas competições requerem tempo, determinação, motivação e curiosidade dos participantes, para assim estimular o seu desenvolvimento, habilidades científicas e intelectuais (PEREIRA \& MOREGA Jr., 2009). A longo prazo, essas competições podem contribuir na escolha da carreira desses alunos (HULER, 1991).

Segundo Klein (2007), é necessário, no ensino básico no Brasil, que se use de artifícios que estimulem o aluno a compreender o conteúdo ministrado em sala de aula. As olimpíadas escolares são consideradas um desses recursos importantes para a motivação e estímulo didático e pedagógico com alunos dos mais diversos níveis, sendo, portanto, observado seu crescimento no meio acadêmico. 
Nos dias atuais, as crianças já nascem mergulhadas no mundo tecnológico. Devido a isso, a Informática vem sendo inserida como ferramenta na educação, para potencializar a construção do conhecimento, fazendo interação entre o dia-a-dia do aluno e o conteúdo da sala de aula. No meio escolar, a Informática é um recurso utilizado para proporcionar a busca e construção de conhecimentos, a partir de interações e trocas de informações, e vem sendo inserida na educação como forma de estímulo no processo de aprendizagem e construir uma escola voltada para a realidade. Para que seja utilizada como recurso pedagógico, e não apenas como uma tecnologia a mais, é necessário direcionar conhecimentos e mecanismos que a integre à educação (MALFATTI et al., 2004).

Dentro desse contexto de utilizar as ferramentas da Informática como recurso educacional e motivador na educação e no desenvolvimento local, o Projeto de extensão universitária "Olímpiada Paraibana de Informática - Sede Areia - PB", vem sendo desenvolvido desde 2013, no Centro de Ciências Agrárias (CCA) da Universidade Federal da Paraíba (UFPB). Coordenado pela professora de Informática do CCA, este projeto conta com o apoio de alunos voluntários dos diversos cursos de graduação desse Campus. 0 objetivo principal do projeto é despertar nos alunos da rede pública e privada de ensino fundamental de Areia-PB o interesse pelos jogos de lógica, matemática e computação, auxiliando, também, na interpretação de texto, fator importante no contexto do ensino básico, atualmente. Estes objetivos são executados através de uma competição saudável que envolve desafios motivadores, troca de ideias, prática constante de exercícios motivadores, utilização dos conhecimentos e situações do cotidiano das crianças do brejo paraibano na contextualização das aulas e exercícios. Os alunos podem participar de competições nacionais e internacionais da área, a exemplo da Olimpíada Brasileira de Informática e a Olimpíada Internacional de Informática (IOI). A execução desse projeto visa, também, melhorar a autoestima dos alunos do brejo paraibano, incentivando a apoiar emios para melhorar o desenvolvimento local, notadamente os residentes na zona rural, uma vez que verifica-se a existência de poucas ações, ou quase nenhuma delas, dos poderes públicos e acadêmicos no trato educacional e social dessa camada da comunidade, no entorno da UFPB.

Diante do conteúdo exposto, o objetivo do presente trabalho é descrever as atividades realizadas no projeto e apresentar os resultados obtidos nessa competição em sua 5ª edição, em 2017.

\section{METODOLOGIA}

A Olimpíada Paraibana de Informática teve sua primeira aplicação no município de Areia-PB no ano de 2013, nos níveis 1 e 2, com alunos do Ensino Fundamental das zonas urbana e rural. Nesta 1a edição, as escolas do município de Areia obtiveram 75\% das medalhas destinadas aos alunos de escolas públicas que atingissem as maiores pontuações em todo o Estado da Paraíba. A partir de 2015, além da Olimpíada Paraibana de Informática (OPI), os alunos também tiveram a oportunidade de participar da Olimpíada Brasileira de Informática (OBI), momento em que Areia, naquele ano, pela primeira vez, participou como município sede desta competição.

A prova da Olimpíada Paraibana de Informática está estruturada em três níveis:

- Iniciação I e II (1ํo ao 8oano do Ensino Fundamental)

- Programação (9o ano do Ensino Fundamental ao Ensino Médio) e

- $\quad$ Avançado júnior (Ensino Superior).

A OBI envolve os níveis Iniciação 1 e 2, Programação e Programação Avançada, com as mesmas séries escolares já citadas, anteriormente.

A organização da OPI-Sede-Areia optou por participar, em nível Estadual, na categoria de Iniciação, com estudantes do $1^{\mathrm{o}}$ ao $8^{\mathrm{o}}$ ano do Ensino Fundamental, e na OBI nos níveis Iniciação 1 e 2, envolvendo assuntos de raciocínio lógico e analítico, nos quais foram apresentados situações-problemas que envolviam o cotidiano dos alunos.

Foi realizada uma parceria com a Secretaria de Educação do Município de Areia-PB, que auxiliou nas inscrições de alunos da zona urbana e rural de toda cidade, com participação de alunos do Ensino Fundamental das escolas públicas e privadas.

Assim, como nas diversas modalidades esportivas, para se obter um bom resultado em uma competição de conhecimento, é importante que haja a preparação do "atleta". Desta forma, são necessárias a organização e a disponibilidade de todos, em termos de tempo e local para o treinamento. Comparativamente, como o 
Enem e outras avaliações nacionais, é necessário que o participante esteja preparado para lidar com as situações propostas. Com o objetivo de melhorar o desempenho dos alunos em suas escolas, de motivá-los em suas aprendizagens, procurando ser um canal opcional na associação do conteúdo ministrado nas escolas e nas competições escolares, a equipe do projeto planejou e executou aulas preparatórias, voltadas para situações cotidianas dos alunos e para as provas das Olimpíadas. Vale salientar que este processo envolveu várias reuniões com professores das escolas, procurando observar os pontos deficientes a serem tratados, bem como os pontos que poderiam ser acrescentados para melhorar o desempenho dos alunos. Destacamos, aqui, que foi necessário acrescentar, no plano de curso das aulas preparatórias, métodos de interpretação de texto, aulas de Ciências e Matemática, contribuindo, significativamente, com o aprendizado dos assuntos dados nas escolas.

Os cursos preparatórios foram ministradas por alunos da Universidade, como voluntários do projeto, na Central de Aulas (Prédio da Mata) do CCA-UFPB, para os alunos da zona urbana. A equipe do projeto se deslocou para as escolas da zona rural, para ministrar os cursos aos alunos lá residentes. Nos cursos preparatórios, foram aplicados exercícios, explicações sobre interpretação de textos, resolução de testes de raciocínio lógico, onde os alunos praticavam, tanto em sala e como em suas casas, simulados referentes ao tema e esclarecimentos sobre a realização da prova da Olimpíada.

A execução do projeto consistiu das seguintes etapas:

- De Fevereiro a Março de 2017: realização do planejamento do projeto, com definição de atividades e ações a serem executadas, reuniões com a equipe local da OPI e OBI, estabelecimento de parcerias, através de contatos e reuniões com diretores de Escolas da zona urbana e rural, técnicos e Secretária da secretaria municipal de Educação (SEC) de Areia-PB.

- De Março a Setembro de 2017: realização da divulgação do projeto, inscrições de alunos, planejamento e execução dos cursos preparatórios, bem como a aplicação das provas da OBI e OPI, em suas Fases 1 e 2.

- De Outubro a Novembro de 2017: correção das provas, divulgação dos resultados, solenidade de premiação e entrega de certificados a todos os participantes inscritos, avaliação geral da equipe do projeto.

0 projeto iniciou com nove turmas, abrangendo escolas na zona urbana e da zona rural. Os alunos atendidos pelo projeto são, em sua grande maioria, residentes nas áreas mais carentes do município de Areia, bem como vivem em situação de grande vulnerabilidade social, enfatizando o aspecto social e inclusivo do projeto. Diante disso, com o intuito de solucionar as poucas condições de locomoção desses alunos, a coordenação do projeto estabeleceu uma parceria com a Secretaria de Educação do Município, onde foram disponibilizados meios de transporte que facilitaram o deslocamento de mais de 100 alunos até à Universidade e aos locais das aulas preparatórias.

Nas aulas ministradas, foram utilizados recursos didáticos, tais como computadores, Datashow e quadrobranco, para facilitar e motivar a aprendizagem dos alunos inscritos. As aulas foram preparadas, seguindo o conteúdo das provas aplicadas em Olimpíadas nacionais da área. Foram desenvolvidos materiais didáticos, como listas de exercícios, simulados e material teórico, pela equipe do projeto. As aulas consistiam em aplicações de exercícios com questões de conhecimento lógico, nos quais os alunos eram auxiliados pelos monitores na interpretação e resolução, onde eram aplicados exemplos dando aos alunos instruções para a resolução da prova. Nas semanas antecedentes às datas das provas, foram aplicados simulados que continham questões de provas dos anos anteriores, fazendo com que os alunos se acostumassem com a execução da competição Estadual e Nacional. Todas essas atividades foram desenvolvidas por alunos voluntários no projeto com a supervisão da professora orientadora.

As provas foram aplicadas por monitores voluntários, e pela professora coordenadora do projeto em salas do Centro de Ciências Agrárias (CCA) da UFPB, com duração de 2,5 horas, cumprindo as exigências impostas pelas organizações estaduais e nacionais como o horário de aplicação das provas e o tempo de prova.

Foram realizadas avaliações periódicas da equipe executora do projeto, através de questionários aplicados com os alunos e parceiros, no início do projeto e após as provas Estaduais e Nacionais. Ademais, a equipe realizou reuniões mensais para avaliar e ajustar, caso necessário, as ações executadas junto à comunidade. 


\section{RESULTADOS E DISCUSSÃO}

Desde o primeiro ano, em 2013, quando a OPI foi introduzida em Areia, com o objetivo de atender alunos em situação de risco e pessoas carentes, tanto da zona urbana quanto da zona rural. Até o momento, cerca de 1.215 alunos se inscreveram no projeto, durante esses anos de sua execução. A evolução participativa dos alunos está ilustrada no Gráfico 1.

Gráfico 1. Evolução de inscritos nas edições da OPI na cidade de Areia-PB.

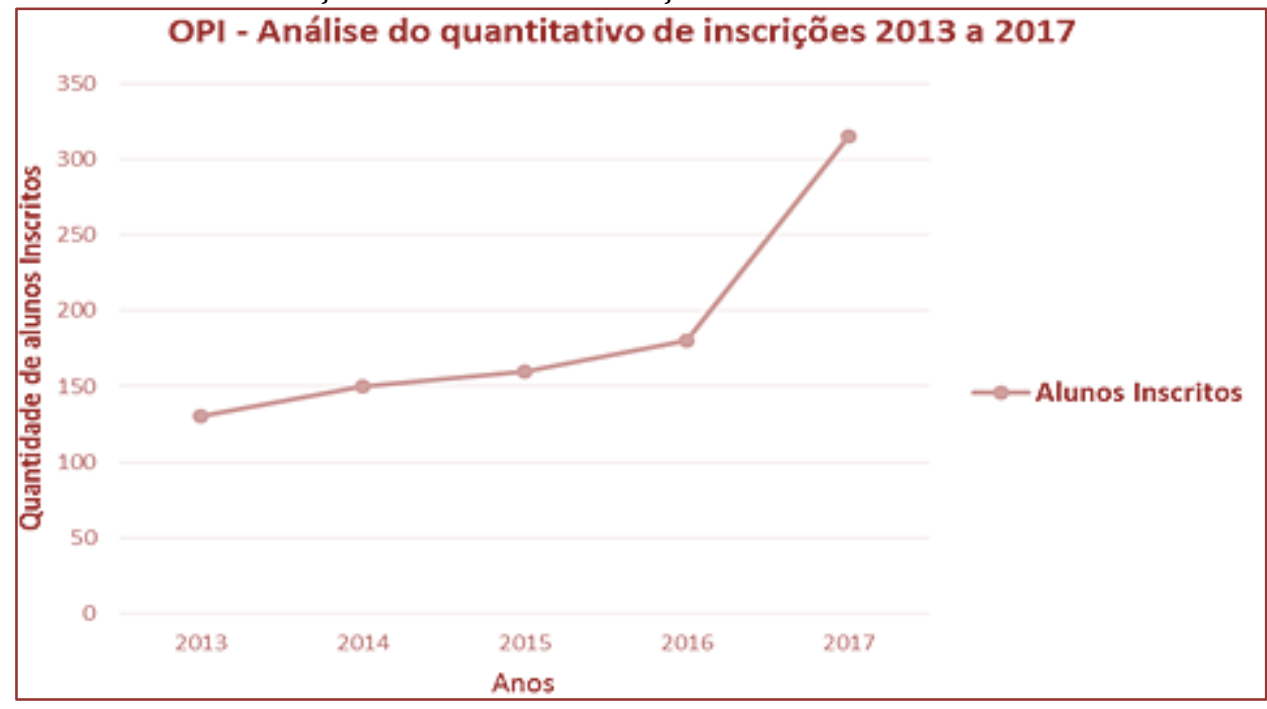

O número de alunos inscritos vem crescendo a cada ano, como ilustrado no Gráfico 1. Isto reflete o trabalho expressivo com a proposta de procurar inserir, cada vez mais, os alunos de diferentes classes sociais e etnias que estudam nas escolas do município, vislumbrando a melhoria de seus rendimentos escolares e estímulo em seus processos educativos.

Em se tratando de resultados concretos, em 2013, apenas com a aplicação da OPI, os alunos treinados pela equipe em Areia obtiveram $75 \%$ das medalhas da competição Estadual na categoria Escolas Públicas. De 2014 até 2017, na mesma competição e também na categoria de Escolas Públicas, os alunos areenses conseguiram $100 \%$ das medalhas. Fato, por si só, considerado extraordinário, refletindo o grande trabalho de inserção social e objetivando a melhoria no desempenho dos alunos carentes da cidade. Além disto, na primeira participação nacional da OBI dos alunos treinados pela equipe da OPI-CCA, 11 alunos foram classificados nessa competição, ficando entre o TOP 300 Nacional.

Superando todas as cidades-sede em nível estadual, em 2017 a sede de Areia/PB conseguiu um total de 318 alunos inscritos na OBI e OPI.

Gráfico 2. Total de alunos inscritos na OPI 2017.

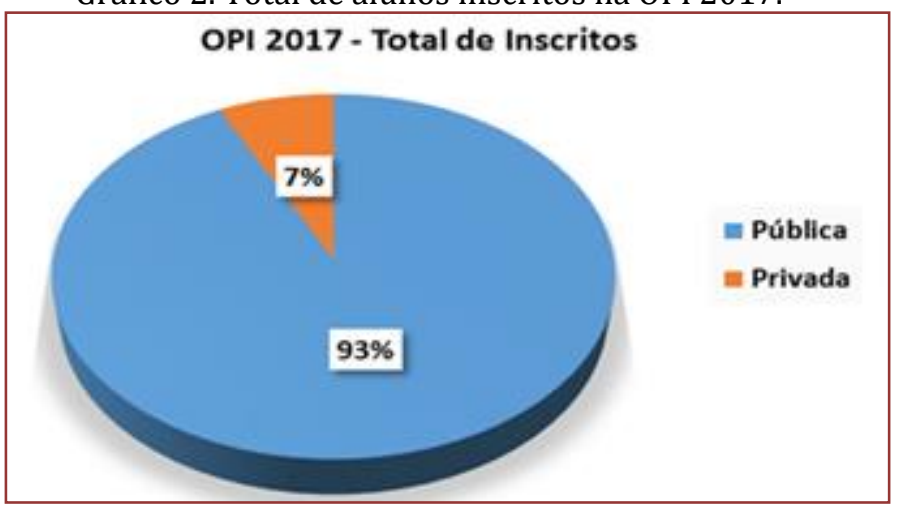


O Gráfico 2 mostra o percentual de inscritos, para a OPI, das escolas públicas e privadas do município de Areia, em que $93 \%$ dos alunos foram oriundos de escolas públicas e $7 \%$ oriundos de escolas privadas. Esse fato foi destacado porque os alunos das escolas públicas sempre melhoraram seus desempenhos escolares com as ações do projeto e se sentiram valorizados e incluídos socialmente.

Gráfico 3. Total de alunos classificados para segunda fase da OPI 2017.

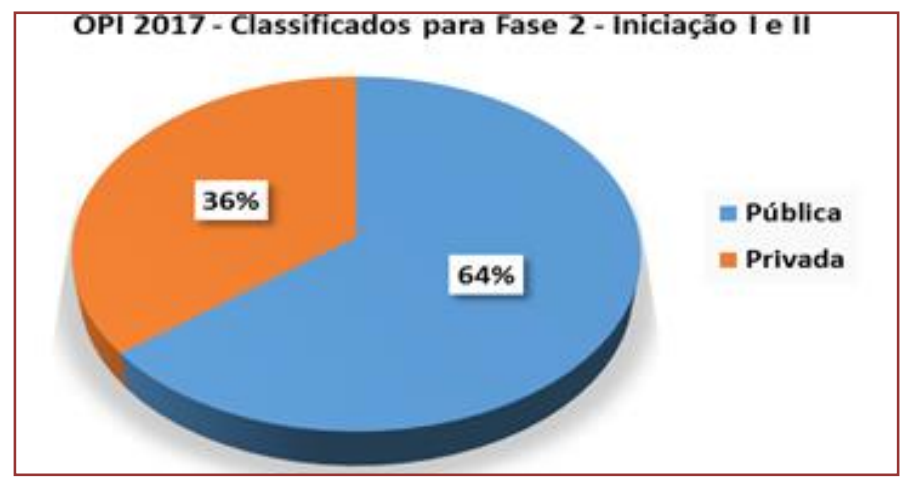

No Gráfico 3, pode-se notar a boa performance dos alunos das escolas públicas de Areia, que obtiveram um quantitativo de classificados para Fase 2 superior em relação às escolas privadas do município. Tal fator demonstra o entusiasmo, disposição e capacidade dos alunos pela busca de novas atividades extracurriculares, uma vez que as ações da OPI - Sede Areia, incentivou-os nos estudos, provendo benefícios no desempenho escolar.

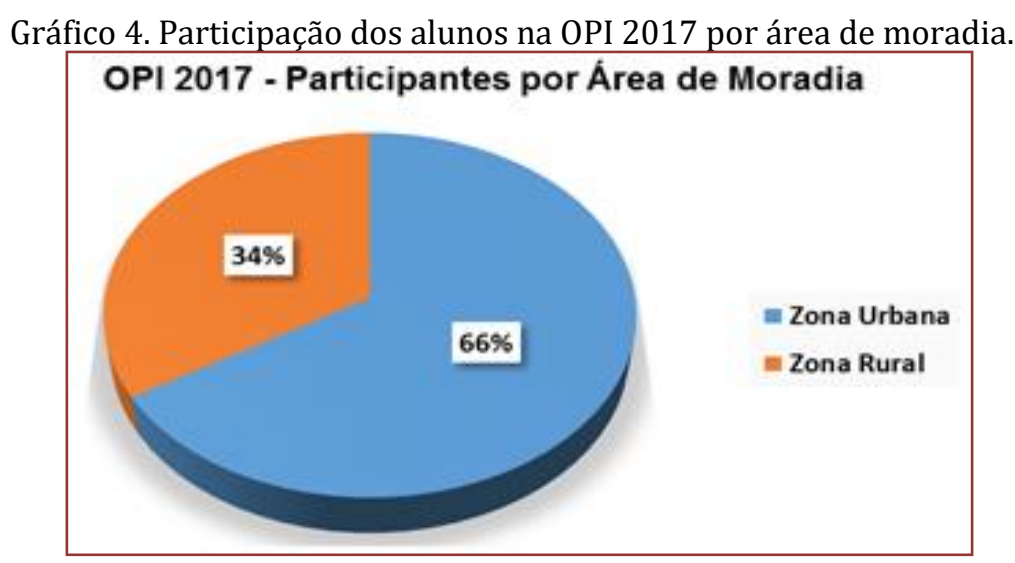

0 Gráfico 4 ilustra o percentual de participantes por zona de moradia. Inscreveram-se, para participar do projeto, 66\% de alunos da zona urbana, de escolas públicas e privadas, e $34 \%$ da zona rural, em sua totalidade de escolas públicas. 0 índice de participantes foi tido como satisfatório, pois fazem parte desse percentual alunos carentes de escolas públicas da zona rural e urbana, dando as mesmas oportunidades para crianças e jovens de diferentes áreas de moradia e classes sociais participarem de um projeto, auxiliando e valorizando pessoas que vivem em situação de grande vunerabilidade social, melhorando seus aprendizados escolares. 
Gráfico 5. Índice de alunos premiados na modalidade Iniciação I da OPI - 2017.

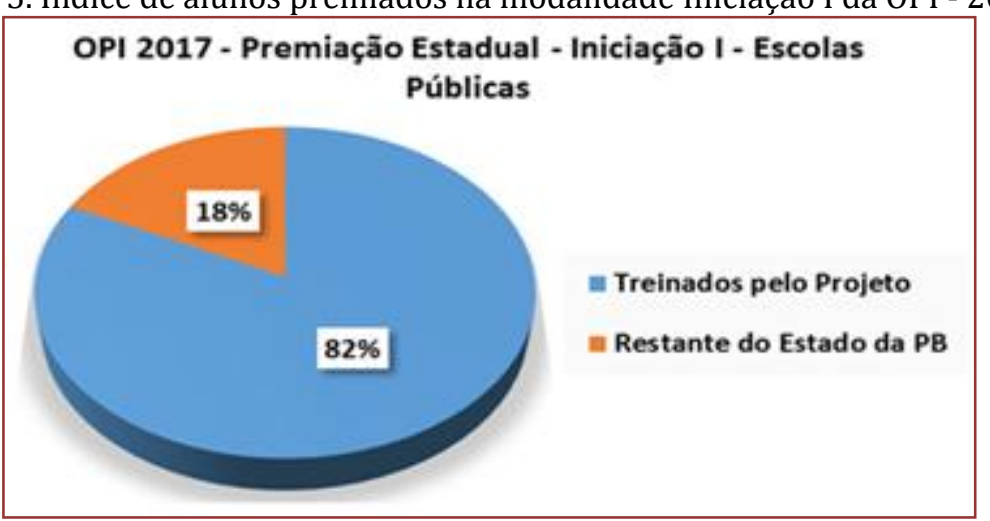

É com grande satisfação que, divulgado o resultado oficial pela Comissão Estadual da OPI, os alunos de escolas públicas, na modalidade Iniciação I, treinados por esse projeto, obtiveram $82 \%$ das medalhas da competição, em relação à 18\% das demais escolas do Estado da Paraíba, conforme mostrado no Gráfico 5. Esse resultado pode ser considerado extraordinário para o projeto, sendo destaque Estadual, evidenciando os benefícios providos pelas atividades e ações executadas com os alunos areenses.

Gráfico 6. Índice de alunos premiados na modalidade Iniciação II da OPI 2017.

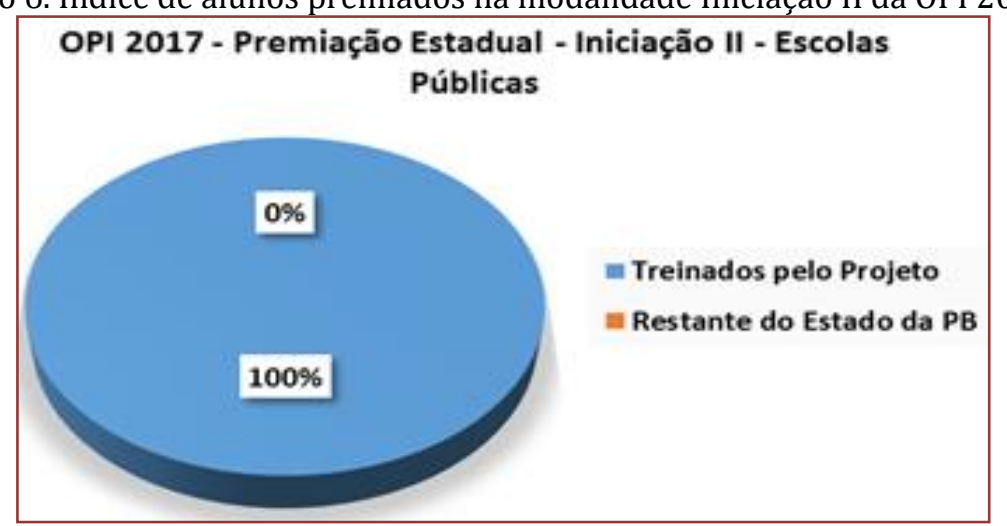

Na modalidade Iniciação II, os alunos treinados pelas equipes da OPI obtiveram $100 \%$ das premiações do estado da Paraíba, como ilustra o Gráfico 6. Já é o terceiro ano consecutivo que os alunos, treinados pela equipe desse projeto, conseguem suplantar, extraordinariamente, todos os alunos da rede pública do Estado da Paraíba, fato que motiva aprimorar e atualizar os métodos e recursos utilizados nas ações executadas nas escolas de Areia.

Figura 1. Aulas preparatórias zona rural, zona urbana e cerimônia de premiação.

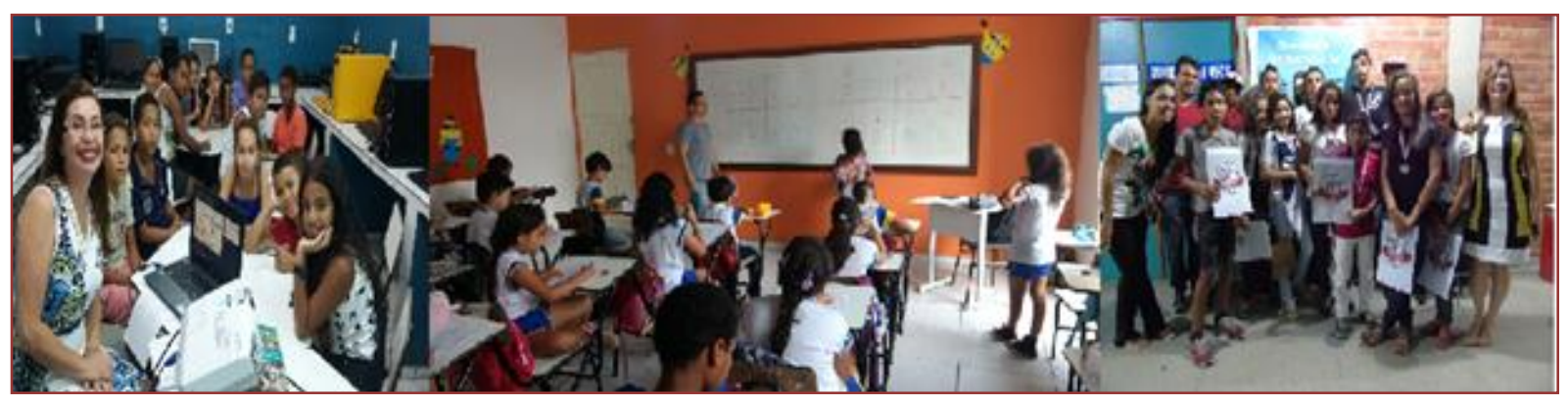


A Figura 1 ilustra momentos de atividades do projeto, como aulas preparatórias com alunos da Iniciação I da Escola Abel Barbosa, na zona rural, aulas preparatórias com alunos de escola privada da zona urbana e a cerimônia de entrega de medalhas e premiação, pela Comissão Estadual da Olimpíada de Informática, aos alunos areenses.

Preparar estudantes para realização de provas de Olimpíadas Científicas é um fator de fundamental importância, visto que, durante as aulas e cursos, os alunos exercitam a mente e expandem sua capacidade de desenvolver um raciocínio lógico de forma rápida e precisa. Tais treinamentos os instigam à praticar estas atividades na escola e em casa, tornando-se um diferencial nos resultados obtidos e aqui expostos.

\section{CONCLUSÕES}

Diante de um cenário educacional, no qual os alunos evidenciam dificuldades em interpretar e compreender os conteúdos, a inserção de jogos e competições saudáveis torna-se uma medida metodológica diferenciada, ao colaborar com a inclusão social de estudantes, com o ensino e com a didática dos professores em sala de aula.

Os resultados obtidos nas Olimpíadas de Informática em Areia foram considerados extraordinários, com a forte participação dos estudantes. A equipe coordenadora do projeto alcançou seus objetivos, ao estimular nos alunos o interesse pela Informáitca, Matemática e pela Ciência, em geral, como também proporcionar oportunidades de aprendizagem iguais a todos estudantes das redes pública e privada de distintas zonas de moradia e classes sociais. Tanto as escolas públicas quanto as privadas, mostraram interesse em incentivar seus alunos a realizarem a prova, e os próprios alunos confirmaram estar interessados, participando das aulas preparatórias e comparecendo no dia de fazer a prova. Além desta perspectiva, pode-se destacar a repercussão municipal das Escolas, em que houve grande número de alunos classificados na OBI e premiados na OPI, incentivando-os à estudar mais, ajudando, inclusive, a sair do ócio, tirando-os da rua e de atividades infrutíferas. A partir dos resultados conquistados, espera-se que, nas próximas edições, esse projeto possa ser ampliado, alcançando outros níveis da competição, provendo um maior interesse e desempenho dos seus participantes.

\section{REFERÊNCIAS}

[1] Alves, E. M. S. A ludicidade e o ensino de matemática. Campinas: Papirus, 2006.

[2] Corrêa, G. M.; Souza, F. R. F.; ABREU, A. S.; Ramos, A. M.; Souza, M. C. Olimpíada Itacoatiarense de Química: um incentivo ao ensino de ciências no interior do Amazonas. In: Reunião da Sociedade Brasileira de Química, 32. 2009, Fortaleza. Anais... Fortaleza: SBQ, 2009.

[3] Fernandes, C. S.; Galiazzi, M. C. As olimpíadas de Química como exercício da prática pedagógica. In: Fórum de Estudos: Leituras de Paulo Freire, 9., Rio Grande. Anais... Rio Grande: FURG, 2007.

[4] Huler, S. Nurturing science' Young elite: Westinghouse. Talent Search. Science, v. 5 n. 20, 1991.

[5] Klein, R. Universalização do ensino básico. O Globo, Rio de Janeiro. 26 jan 2007. Disponível em: www.undime.org.br/htdocs/index.php. Acesso em: 26 Jul. 2017.

[6] Lopes, G. S. Ambientes Virtuais de Ensino: aspectos estruturais e tecnológicos, 2001. Dissertação (Mestrado em Engenharia de Produção) - Universidade Federal de Santa Catarina, Florianópolis.

[7] Malfatti, S. M.; Nunes, M. A. S. N.; Francisco, D. J.; Ribas, J. F.; Engers, E. M. B. Logo 3D - Uma ferramenta auxiliar no aprendizado da geometria Espacial. In: XIII SIMPÓSIO Brasileiro de Informática na Educação, SBIE 2002. Anais... São Leopoldo, v. 1, p. 562-565, 2002.

[8] Nascimento, M. G.; Palhano, D.; Oeiras, J. Y. Y. Competições escolares: uma alternativa na busca pela qualidade em educação. In: Workshop em Informática na Educação, SBIE 2007. Anais... São Paulo, 2007.

[9] Pereira, R. G.; Marega Jr, E. A Olimpíada brasileira de Física no estado de São Paulo e a difusão do conhecimento na universidade de São Paulo. Revista Cultural e Extensão, v. 1, 2009.

[10] Rezende, F; Ostermann, F. Olimpíadas de Ciências: uma prática em questão. Ciência \& Educação, v. 18, n. 1, p. 245-256, 2012.

[11] Robinson, S. Coaching a High School Science Olympiad Team. Academic Exchange, ed. Summer, p. 272-277, 2003. 


\section{Capítulo 13}

O curso de bacharelado em direito da UESPI, campus de Picos (PI): O fortalecimanto da educação jurídica no semiárido piauiense

Lauro Brandão Lima Neto

Evandro Alberto de Sousa

Luciano Silva Figueirêdo

Janaína Alvarenga Aragão

Lucelia de Moura Rocha Barbosa

Alekssandro Sousa Libério

Resumo: A história do curso de Direito da Universidade Estadual do Piauí campus Professor Barros Araújo se confunde com a própria história do campus universitário, a instituição do referido curso foi fruto da união dos estudantes universitários e dos representantes públicos à época. Segundo o projeto pedagógico do curso, o seu objetivo geral é a formação de profissionais da área jurídica de maneira responsável e com habilidade de transformar positivamente a sociedade na qual esteja inserido. 0 presente estudo propõe um relato sobre o panorama geral do curso de Direito da Universidade Estadual do Piauí campus Prof. Barros Araújo, ressaltando a sua importância no contexto do semiárido piauiense, e, para tanto, utilizou a análise documental. As atividades acadêmicas do curso de Bacharelado em Direito são desenvolvidas com enfoque nos contextos profissional e social, e privilegia a interdisciplinaridade, com proposta metodológica de ensino centrada nos princípios pedagógicos do fazer e aprender. Embora com limitações, resta confirmado que, desde sua implementação, o curso de Direito de Picos vem formando profissionais qualificados e com formação políticaeducacional legitima, justa e humanizada, se mostrando de suma importância no contexto social do semiárido. 


\section{INTRODUÇÃO}

Em 1988, o Poder Executivo Estadual proporcionou as condições necessárias à instalação e ao regular funcionamento do CESP como Universidade Estadual do Piauí. Em 1991, através do Decreto Federal no 042/91, o então presidente Itamar Franco autorizou o funcionamento da UESPI em estrutura multicampi, com sede em Teresina - Campus do Pirajá. Foram também instalados nesse período os Campi de Corrente, Floriano, Parnaíba e Picos.

A Universidade Estadual do Piauí é uma instituição de ensino superior pública que tem como missão oferecer ensino de qualidade e realiza atividades de pesquisa e extensão condizentes com a realidade estadual e desta forma contribui para o desenvolvimento educacional, social, econômico e cultural do Piauí. Em resumo a meta da Universidade Estadual do Piauí é: "Ser uma Universidade comprometida com o ensino, a pesquisa e a extensão voltados para a qualidade de vida do povo piauiense.".

Com uma estrutura composta de 35 centros universitários, com mais de 20 mil alunos e cerca de 1430 professores em seu quadro funcional, a UESPI tem buscado sua autonomia administrativa e financeira, a fim de resguardar seus princípios estatutários e cumprir suas finalidades que são a promoção do ensino, da pesquisa e da extensão integrados na formação técnico-profissional e na produção científica, tecnológica, filosófica, artística e cultural.

O curso de Direito da Universidade Estadual do Piauí campus Prof. Barros Araújo teve sua história de fundação ligada diretamente à história do próprio campus da UESPI de Picos - PI. Foi reconhecido através do Decreto de $n^{\circ} 10.224$, assinado no dia 22 de dezembro de 1999 e publicado no Diário Oficial da União no dia 28 de dezembro de 1999.

A instalação do curso de Direito do Campus Prof. Barros Araújo foi possível graças à consonância da comunidade universitária da época e dos representantes públicos que se uniram pela fundação do curso. Após quatro anos de funcionamento do campus, tendo em vista a crescente demanda e o aumento no número de alunos e a polarização da cidade de Picos em relação a outras cidades vizinhas, a fundação foi efetivada no dia 22 de março de 1996, assumindo a primeira turma no ano seguinte de 1997, tendo sido ofertadas vagas todos os anos até o presente.

Segundo o projeto pedagógico do curso de Direito da universidade estadual do Piauí se tem por objetivo geral a formação de profissionais da área jurídica de maneira responsável e com habilidade de transformar positivamente a sociedade na qual esteja inserido. Fomenta ainda levar ao mercado de trabalho profissional com formação humanística e técnica para bem aplicar o Direito como forma de promover a justiça social.

Diante dessa introdução, este artigo se propõe fazer um relato sobre o panorama geral do curso de Direito da universidade estadual do Piauí campus professor Barros Araújo, situado em pleno semiárido piauiense, ressaltando a importância deste no contexto social.

\section{MATERIAL E MÉTODOS}

Este artigo de relato de experiência utilizou como técnica metodológica a análise documental. Esse tipo de análise leva em consideração os dados coletados nos arquivos de elementos significativos para exposição do trabalho. Para Yin (2001) afirma que uma apresentação dos dados é boa quando os elementos significativos são apresentados, as perspectivas diferentes são levadas em consideração, os elementos críticos de análise são expostos e o estudo é de leitura fácil e agradável.

Utilizou-se como base documental o PDI e o PPC além de registros arquivados na coordenação do curso de Direito, onde foram analisados esses documentos em conjunto com os relatos de alguns professores da UESPI. Os documentos PDI e PPC serviram de base bibliográfica, visto que dentro desses arquivos se encontra toda a história da instituição e é levado em consideração todo o contexto social, político e educacional no qual o semiárido piauiense se encontra. Para Manzo (1971) a bibliografia oferece meios para definir, resolver, não somente problemas já conhecidos, como também explorar novas áreas onde os problemas não se cristalizam suficientemente.

\section{RESULTADOS E DISCUSSÃO}

Atualmente, o Piauí está consolidado como grande Polo Educacional, ofertando todos os níveis de ensino. Exportam óleo e amêndoa de babaçu, couro, algodão em pluma, arroz, gado, telhas e tijolos, castanha de 
caju, cara de carnaúba e pescado (IBGE, 2014). Anualmente o Estado realiza vários eventos para atrair investidores como feiras agropecuárias, que atraem produtores de toda região e gerando uma movimentação econômica no agronegócio regional.

O levantamento do último Censo da Educação Superior (INEP, 2012) mostrou que as Instituições de Ensino Superior do interior do Piauí ofertam poucas vagas para atender a demanda regional. Esse quantitativo de vagas, por não atender à demanda, contribui para que os jovens estejam fora das universidades e faculdades ou migrem em busca de novas oportunidades de estudo e trabalho. Os dados estatísticos do último levantamento do IBGE (2014) mostraram que a população regional matriculada no ensino médio no Piauí era de cerca de 198.000 estudantes que concorrem a pouco mais de 80 mil vagas na educação superior ofertada pelas IES do Estado. Isso implica numa defasagem enorme de vagas. Como reflexo, o Estado possui pouco mais de 3\% da população com um curso superior completo. A UESPI, neste contexto, contribui para criar oportunidade de estudo e qualificação para essa parcela da população que possui uma carência de vagas no ensino superior da região.

A cidade de Picos reúne condições favoráveis para o surgimento de novos postos de trabalho na área jurídica. A cidade se localiza numa posição geográfica estratégica, circulada por mais de 50 entre cidades, vilas e povoados do próprio Estado como de outros, que diariamente consomem os bens e serviços da cidade. É o segundo entroncamento do nordeste brasileiro sendo cortada por três BRs, facilitando o escoamento e a entrada de bens. A atividade econômica predominante é o comércio e a prestação de serviços.

De acordo com as Diretrizes Curriculares Nacionais para o curso e carga horária com tempo de integralização de acordo com a Resolução CNE/CES N. 02/2007, Resolução CNE N. 004/2009, Resolução CNE/CP N. 2/2002 e Resolução CNE/CP N. 001/2006.

Tabela 1 - Resumo da MATRIZ Curricular

\begin{tabular}{|c|c|}
\hline RESUMO & CARGA-HORÁRIA \\
\hline CARGA HORÁRIA DAS DISCIPLINAS & $3.345 \mathrm{H}$ \\
\hline DISCIPLINAS OPTATIVAS & $90 \mathrm{H}$ \\
\hline ESTÁGIO SUPERVISIONADO & $360 \mathrm{H}$ \\
\hline ATIVIDADES COMPLEMENTARES & $200 \mathrm{H}$ \\
\hline TCC & $120 \mathrm{H}$ \\
\hline TOTAL & $4.115 \mathrm{H}$ \\
\hline
\end{tabular}

A proposta metodológica definida, para o curso de Bacharelado em Direito da UESPI considera os seguintes parâmetros para o ensinar e o aprender:

- $\quad$ promoção da articulação entre a teoria e a prática;

- aproximação entre o conhecimento, o aluno, a realidade e o mundo do trabalho onde ele se insere;

- apropriação de competências duráveis sob a forma de conhecimentos, desenvolvimento de habilidades, hábitos e atitudes gerais e específicas alinhadas ao disposto nas Diretrizes Curriculares Nacionais para o curso;

- transposição do conhecimento para as variadas situações da vida e da prática profissional.

Levando em consideração estes pressupostos, as atividades acadêmicas do curso de Bacharelado em Direito são desenvolvidas com enfoque que se articula com os contextos profissional e social e privilegia a interdisciplinaridade. A proposta metodológica de ensino está centrada nos princípios pedagógicos do fazer e aprender, determinando a utilização de estratégias, atividades e tecnologias da informação que permitam ao aluno mobilizar, articular e colocar em ação os conhecimentos, habilidades, atitudes e valores necessários para o desempenho eficiente e eficaz das atividades requeridas pela natureza do trabalho.

Tomando por referência a política de ensino constante no PDI da UESPI e a política educacional brasileira, o curso de Bacharelado em Direito elege como prioridade a formação profissional decorrente das demandas sociais regionais e das necessidades do mercado de trabalho. 
A articulação entre as dimensões social, ética, cultural, tecnológica e profissional, o desenvolvimento do ensino no âmbito do curso privilegia o reconhecimento e a valorização da diversidade cultural, imprimindo um significado universal às competências desenvolvidas, pressupondo:

a) a análise dos impactos sociais, políticos e culturais na conformação e continuidade das diferentes espécies de vida em função das condições em que se dá a ocupação dos espaços físicos, levando à compreensão da complexa relação homem-meio ambiente;

b) a aplicação das inovações tecnológicas, entendendo-as no contexto dos processos de produção e de desenvolvimento da vida social e do conhecimento;

c) a atenção para os interesses sociais, sobretudo, no que diz respeito à constituição da vida cidadã, através do acompanhamento das contínuas transformações políticas, econômicas, sociais e culturais regionais e globais.

\section{CONCLUSÕES}

Apesar das limitações, fica evidente a contribuição do Curso de Direito da UESPI campus de Picos para o desenvolvimento econômico, social e político do município, como também da macrorregião.

Vale apontar, que desde 1997 quando foi ofertado o primeiro vestibular do Curso de Direito no campus Barros Araújo em Picos, até os dias atuais a instituição ofereceu ao mercado de trabalho profissionais qualificados o que tem contribuído para o desenvolvimento econômico do mercado local como também da macrorregião.

Por fim, entendemos que o curso de Direito no semiárido piauiense é concebido como um direito aos cidadãos que desejam ser representantes da justiça, além de proporcionar uma experiência políticaeducacional legitima, justa e humanizada.

\section{REFERÊNCIAS}

[1] Plano de Desenvolvimento Institucional - PDI 2011.

[2] Projeto Pedagógico do Curso de Direito - PPC 2015.

[3] Uespi em números. Disponível em: <http://www.uespi.br/site/wp-

content/themes/uespi/uespi_em_numeros.html>. Acesso em 19 de outubro de 2016.

[4] Bastos, Núbia M. Garcia. Introdução à metodologia do trabalho acadêmico. 4. Ed. Fortaleza: Nacional, 2006. 


\section{Capítulo 14}

\section{Semente crioula e sua importância na agricultura familiar do Semiárido Brasileiro}

\section{Kilson Pinheiro Lopes}

Marília Hortência Batista da Silva Rodrigues

Maria Verônica Lins

Hugo Vieira

Resumo: A agricultura familiar tem dado uma importante contribuição na produção de alimentos básicos no país, principalmente no semiárido do nordeste brasileiro, onde predominam a exploração das variedades locais, também denominadas de variedades crioulas, adaptadas às condições ambientais reinantes naquela região. Estas variedades locais são repassadas de geração em geração, através das sementes, que representam o sustentáculo dessa agricultura e carrega consigo toda a identidade genética e cultural da exploração agrícola na região. Contrariando esta cultura, surge a incorporação da prática da inserção dos alimentos industrializados, oriundos da atividade agrícola patronal com a exploração de cultivares melhoradas geneticamente para atender demandas específicas de mercado, colocando em cheque a manutenção do patrimônio genético presente nas sementes crioulas empregadas pelos agricultores familiares, comprometendo sua soberania e a segurança alimentar. A prática do manejo dos recursos genéticos pelos agricultores surgiu desde que começaram a cultivar as plantas. Porém, desde a "revolução verde", o processo de erosão genética vem se acelerando e comprometendo os esforços empreendidos pelos agricultores(as) no sentido de conservar e melhorar suas variedades. Neste sentindo, as sementes das variedades locais, especialmente as sementes crioulas, desempenham um papel de fundamental importância por garantir aos agricultores familiares uma fonte, de recurso genético, pronta e com característica de adaptação às condições locais. Para impedir a perda dessa identidade genética, várias alternativas devem ser realizadas na tentativa de garantir a manutenção da soberania alimentar bem como a reprodução e conservação das sementes locais de forma sustentável. 0 incentivo à manutenção de bancos Comunitário de Sementes, organização que conta com a participação dos agricultores para garantir o acesso à sementes de boa qualidade, em quantidade suficiente e no período certo do plantio, pode ser uma das ferramentas empregadas, visando, sobretudo, a divulgação da importância da conservação dessa riqueza natural como de fundamental importância na garantia da soberania alimentar, fixando o homem do campo e fortalecendo a agricultura familiar.

Palavras-chave: Segurança alimentar, Recurso genético, Agrobiodiversidade. 


\section{INTRODUÇÃO}

No estabelecimento das relações humanas é impossível pensar a formação das civilizações sem considerar a presença da semente, pois está presente na vida humana há mais de 10 mil anos, desde a construção da civilização, a evolução cultural, a história, e até mesmo os mitos (FRANÇA; GARCIA, 2014). A semente é biologicamente um instrumento de reprodução e regeneração das plantas, botanicamente caracterizadas como sendo "um óvulo desenvolvido após a fecundação e que contem o embrião" (VIDAL; VIDAL, 2006).

Desde o começo da humanidade, agricultores e agricultoras têm conservado, selecionado e melhorado sementes, dando origem a uma grande diversidade de cultivos e variedades utilizadas na produção agrícola. Os agricultores têm sido desde sempre os responsáveis pela manutenção da biodiversidade de cultivos, mantendo variedades adaptadas a diferentes regiões, por gerações (ARAÚJO et al., 2013). Porém atualmente o processo de erosão genética tem provocado o desaparecimento das sementes tradicionais, ou seja, tem levado a erosão genética consequente da extinção das sementes que são adaptadas às condições climáticas locais, causando consideráveis impactos negativos ao meio ambiente.

Todo este processo de erosão genética surgiu a partir da substituição de insumos tradicionais como a semente crioula por insumos produzidos pela indústria de agroquímicos e, como consequência desse processo, a dependência dos agricultores em relação às empresas que fornecem estes insumos (MEIRELES; RUPPI, 2006). Outras consequências são citadas por Vasconcelos, (2013) como a exclusão social, êxodo rural, contaminação da água e do solo, contaminação dos agricultores e dos consumidores, entre diversas outras consequências ambientais e sociais. Para Queiroga et al. (2011) a busca por alternativas na produção de sementes pelos agricultores familiares está diretamente relacionada ao acesso e aos altos custos empregados nas sementes manipuladas geneticamente bem como às dificuldades financeiras daqueles agricultores.

Diante disto faz-se necessário a valorização das sementes tradicionais para manter a biodiversidade local e o fortalecimento da agricultura familiar no semiárido brasileiro, sendo fundamental a preservação, seleção, resgate e adequado armazenamento das sementes para garantir a permanência de tal biodiversidade genética e a soberania alimentar da região.

\section{DESENVOLVIMENTO}

\section{10 PAPEL DA SEMENTE NA AGRICULTURA FAMILIAR}

O Brasil possui uma grande biodiversidade dentre as distintas realidades sociais, econômicas, culturais e ambientais, esta ultima de grande complexidade, pois cada região do país possui características edafoclímaticas diferentes. Levando em consideração o clima temperado e subtropical, a região sul caracteriza-se como uma das regiões mais ricas onde grande parte dos agricultores familiares são descendentes dos imigrantes europeus que vieram no século XIX, trazendo consigo suas sementes. Já o nordeste possui diferentes ecossistemas, o litoral apresenta estações chuvosas e secas bem definidas e o interior apresenta clima semiárido, mas acima de tudo, uma região castigada pelo uso intensivo do solo através da monocultura. Diante de cada contesto regional a semente apresenta diferentes funcionalidades, enquanto na região sul do país a semente representa autonomia e regaste da tradição, no nordeste ela é sobretudo, uma questão de sobrevivência (GARCIA, 2004).

A conservação e manutenção da diversidade genética presente na semente tem como base as transformações causadas pela "Revolução Verde" caracterizada pelas mudanças das atividades agrícolas iniciadas e disseminadas de maneira devastadora desde $1940 \mathrm{em}$ âmbito global. No Brasil foi constante a partir de 1960, tendo como principal objetivo o aumento da produção agrícola baseada em um pacote tecnológico, incluindo sementes hibridas, uso indiscriminado de agroquímicos, uso intensivo do solo e mecanização pesada, em busca de maiores produtividades (SAUER, 2010).

Conforme Queiroga et al. (2011), a produção de sementes de diversas espécies cultivadas na região semiárida do nordeste do Brasil é de grande importância, pois a qualidade da semente representa uma das fontes de segurança da sustentabilidade alimentar do homem que cultiva a terra e da sua família, buscando assegurar o futuro e a valorização dos saberes científicos e empíricos. Diante disto, surge o papel econômico, social e cultural desempenhado pelas sementes, uma vez que é um organismo vivo que garante o sustento das famílias, oferece um alimento de qualidade, garante também segurança alimentar e permanece na família por longas gerações (PALÁCIO FILHO et al., 2011).

Barbosa et al. (2010) citam ainda que os agricultores valorizam as sementes por garantirem além dos benefícios citados acima, a segurança alimentar dos animais domésticos, replantio da próxima safra e 
ainda pode-se citar o valor cultural associados a estas por fazerem parte da historia de gerações que são passadas de pai para filho, bem como o método adequado de cultivo das mesmas.

Conforme Soares e Alba (2009), a semente é um componente da identidade cultural e patrimônio biológico de comunidades rurais, e não apenas um insumo agrícola ou uma mercadoria, pois ela contem o segredo da vida e conservam historias das famílias que as preservam. Diante disto faz-se necessário uma abordagem sistêmica da erosão genética e suas consequências, da importância e funções dos bancos de sementes e a valorização e conservação das sementes crioulas.

\subsection{A SEMENTE CRIOULA}

Sementes crioulas podem ser denominadas como sementes que não sofrem modificações genéticas por meio de técnicas como as realizadas no processo de melhoramento genético. Estas sementes são chamadas de sementes crioulas, nativas ou tradicionais porque, habitualmente, seu manejo foi desenvolvido pelos agricultores familiares das comunidades rurais (BARBOSA et al., 2015).

As sementes crioulas no Brasil apresentam boas qualidades nutricionais e estão bem adaptadas às condições ecológicas locais e necessitam de baixas quantidades de insumos agrícolas quando comparadas com as variedades modernas que apresentam uma constituição nutricional baixa em vários nutrientes e precisam de todo um pacote tecnológico para que se possa produzir (DAVIS, 2009). Palácio Filho et al. (2011), destacam que a semente crioula oferece ainda ao agricultor familiar um outro grande beneficio que está atrelado à capacidade de serem armazenadas para posterior reutilização em safras seguintes, tornando desta forma desnecessário a compra de sementes comercializadas, haja vista que essas sementes são altamente perecíveis impossibilitando o seu armazenamento por mais de um ano. Outras vantagens das sementes crioulas citada por Carpentieri-Pípolo et al. (2010) é a resistência a doenças, pragas e às variações climáticas.

De acordo com Cordeiro, (2002) e Sevilla Guzmán (2005) a semente crioula apresenta grande importância por incorporar os princípios de respeito às culturas locais, à construção de uma tecnologia adequada e de baixo custo e impacto e, carregam uma alta variabilidade genética. Só no agreste paraibano foram identificadas e conservadas diversas variedades de sementes adaptadas às condições locais, dentre elas 28 variedades de feijão de arranque (Phaseolus vulgaris), 22 de feijão macassa (Vigna unguiculata) e 17 de fava (Phaseolus lunatus).

Segundo Barbosa et al. (2010), por intermédio das sementes crioulas é possível preservar a agrobiodiversidade, o equilíbrio e a qualidade das plantas. Toda e qualquer forma de vida presente na terra possui papel fundamental no controle e na manutenção da natureza. Em um cultivo estabelecido a partir de sementes convencionais, ou seja sementes cuja variabilidade genética é menos diversa, há maior possibilidade de insucesso consequente de variações ambientais. Ao passo em que se trabalhando com sementes crioulas o efeito é inverso, pois as plantas não são uniformes, por este motivo podem apresentar maior resistência às variações climáticas e maior capacidade reprodutiva. Diante disto os agricultores familiares têm buscado o resgate, a conservação e distribuição entre os próprios agricultores, pois a semente garante a alimentação, a reprodução da vida e da cultura camponesa.

A grande diversidade genética das variedades adaptadas à região possibilitou que houvesse uma seleção natural e uma seleção pelos agricultores promovendo adaptação destas variedades à diferentes ambientes, mesmo distantes dos centros de domesticação. Nestes locais, características foram desenvolvidas e mantidas nos diferentes genótipos de semente, muitas não encontradas nas demais regiões ou mesmo nas regiões de origem. Em locais distintos foram selecionados diferentes espécies, mesmo que algumas práticas tenham sido semelhantes, as espécies domésticas e a forma de utilização foram incorporadas aos valores e aos ritos dos habitantes e comunidades daquelas regiões. Diante disto a diversidade genética é o resultado de fatores de natureza histórica, ecológica, genética e cultural, configurando-se assim um sistema coevolutivo que a própria cultura humana moldou e adaptou os sistemas biológicos, e estes moldaram a cultura.

As sementes crioulas podem além de gerar renda para os agricultores familiares do semiárido também representam a liberdade de escolha de qual variedade cultivar para o consumo familiar. Aliado a isto, a adaptação fenotípica destas variedades às condições ambientais da região, garantem produtividade onde as variedades comerciais, geralmente, apresentam queda de rendimento. Sendo desta forma uma alternativa viável economicamente para o produtor, resguardando sua independência, diminuindo seus custos de produção, resguardando sua soberania alimentar e manutenção de sua biodiversidade sementeira (SARAVALLE, 2014). 
Segundo Londres (2014), várias pesquisas mostram a superioridade das sementes crioulas ou tradicionais quando comparadas às sementes melhoradas em centros de pesquisa nas condições de solo, clima e manejo empregados pela agricultura familiar do semiárido nordestino. As sementes melhoradas produzem significativamente quando é possível fornecer água e nutrição, sendo alguns destes fatores limitantes de produção nos ambientes da região semiárida.

\subsection{EROSÃO GENÉTICA}

Apesar da significativa importância das sementes crioulas para as comunidades agrícolas, a crescente substituição de variedades tradicionais por cultivares melhoradas hibridas e/ou transgênicas ao longo dos anos tem contribuído para o estreitamento da base genética das plantas cultivadas. 0 processo que inclui a extinção ou drástica diminuição da população de variedades locais ou crioulas é denominado de erosão genética, causando aos agricultores familiares dependência permanente destes em relação aos programas governamentais que nem sempre distribuem as sementes em tempo hábil para o plantio que é o período chuvoso (LONDRES, 2014).

Boef, (2007), destaca que as variedade crioulas possuem combinações alélicas importantes e a troca destas, por cultivares geneticamente modificadas gera não somente a erosão genética, mas também pode ameaçar o conhecimento tradicional de cultivos peculiares à determinadas região. Conforme Almeida (2004) o constante e acelerado processo de erosão genética tem posto em risco a permanência desse curso histórico coevolutivo. Em virtude da influência da rápida e ampla disseminação do modelo técnico cientifico da "Revolução Verde", os agricultores e com eles a agrobiodiversidade vem sendo padronizada. Este é o modelo produzido em escala global por nações ricas, transnacionais que buscam o total controle tecnológico. Em contrapartida não se responsabilizam pelos efeitos sociais e ambientais causados pela perda do patrimônio genético desenvolvido pela humanidade há séculos.

Segundo Oliveira (2014), um dos principais fatores responsáveis pela perda da biodiversidade genética presente nas sementes e dos conhecimentos associados à essa diversidade foram causados pela Revolução Verde, onde tem como estratégia a padronização produtiva pelo uso de espécies hibridas. Esta implicou em um grande abandono das variedades adaptadas às condições locais, buscando uma eficiência produtiva questionável, especialmente para a agricultura familiar.

De acordo com Barbosa et al. (2015), a conservação de recursos genéticos, como a semente, é atualmente umas das questões de maior relevância para a humanidade. Os ecossistemas enfrentam diferentes mudanças globais passando por fortes pressões antropogênicas e mudanças climáticas, portanto a erosão e perda da diversidade genética é uma realidade devastadora, causando prejuízos irreversíveis para a agrobiodiversidade.

\subsection{ESTRATÉGIAS DE CONSERVAÇÃO DAS VARIEDADES CRIOULAS}

Garantir a preservação das variedades locais e a soberania alimentar para a população são os principais benefícios das sementes crioulas, que vêm sem cultivadas e protegidas pela agricultura camponesa. 0 emprego e conservação destas sementes nativas caracterizam o enfrentamento ao avanço dos transgênicos e biofortificados na região nordeste.

Dentre as estratégias que podem funcionar como meio de manutenção de tão precioso recurso genético presentes nas variedades locais cultivados pelos pequenos agricultores familiares destacam-se a busca por reforçar a importâncias destas sementes, estimular os agricultores a resgatá-las, guardá-las e manejá-las adequadamente. Neste sentido, o estabelecimento de bancos de sementes comunitários surgiu a partir da necessidade de se armazenar grande quantidade de sementes, garantindo desta forma a segurança alimentar aos agricultores familiares bem como a possibilidade de preservar sementes de qualidade das variedades adaptadas às condições locais para as gerações futuras (PALÁCIO FILHO et al., 2011).

Conforme Queiroga et al. (2011) os bancos de sementes são de fundamental importância para proteger as variedades nativas e pesquisar novas cultivares não só para a sobrevivência de quem consume mais também para melhorar a qualidade de vida e competitividade produtiva. Conforme Norgaard, (1989), outra prática frequentemente realizada pelas comunidades camponesas, que trabalham com os bancos de sementes, é a troca de sementes crioulas possibilitando assim a disseminação das espécies de plantas mais importantes para a alimentação. 
Varias razões motivaram os agricultores da região semiárida a valorizar as sementes principalmente através de bancos de sementes, dentre estas razões destacam-se as características edafoclimáticas adversas presente na região, com grandes períodos de estiagem (CORDEIRO, 1993).

Segundo Londres (2014), os bancos de sementes representam um mecanismo de segurança em relação à aquisição das sementes locais ou crioulas, garantindo aos agricultores familiares a disponibilidade quando seus próprios estoques se esgotarem ou forem comprometidos. Os trabalhos de resgate de sementes crioulas estão diretamente associados ao patrimônio genético e cultural e, por conseguinte, caracterizamse como estratégias que contribuem para a chamada "agrobiodiversidade" (LINHARES; RODRIGUES, 2008)

\section{CONCLUSÃO}

A crescente exploração dos recursos naturais pode comprometer a sustentabilidade e trazer sérias consequências para a vida animal e vegetal.

A semente crioula representa para a agricultura familiar no semiárido do Nordeste brasileiro um recurso de garantia da variabilidade genética vegetal, capaz de garantir a sobrevivência das espécies locais em função da capacidade de se adaptarem e resistirem às condições adversas, garantindo a soberania alimentar.

As sementes crioulas ainda cumprem o papel como instrumento para fixação do homem do campo e fortalecendo a agricultura familiar.

\section{REFERÊNCIAS}

[1] ALMEIDA, P. Revalorizando a agrobiodiversidade. Agriculturas - v. 1. no 12004.

[2] BARBOSA, F. R. S.; RIBEIRO, G. G.; DIAS, M. S.; ASSUNÇÃO, H. F.; RIBEIRO, D. D. Banco de sementes: autonomia para o pequeno produtor do sudoeste goiano. Cadernos de Agroecologia, v. 5 n.1, p.2, 2010.

[3] ARAÚJO, S. L.; MORAIS, R. C.; MORAIS, R.; NUNES, F. R.; COSTA, C.; SANTOS, M. S. Guardiões e guardiãs da agrobiodiversidade nas regiões do Cariri, Curimataú e Seridó Paraibano. Cadernos Agroecológicos, v. 8, n. 2, p. 1-5. 2013.

[4] BARboSA, V. L.; VIDOTTO, R. C.; ARRUDA, T. P.; Erosão Genética e Segurança Akimentar SICI-SIMPÓSIO INTERNACIONAL DE CIÊNCIAS INTEGRADAS, realizado na UNAERP - Campus Guarujá, Artigo, p.03, 2015.

[5] BOEF, W. S. Biodiversidade e agrobiodiversidade. In: BOEF, W. S.; THIJSSEN, M.; OGLIARI, J. B.; STHAPIT, B. R. (Org.) Biodiversidade e agricultores: fortalecendo o manejo comunitário. Porto Alegre: L\&PM, 2007. cap. 2, p. 36-40.

[6] CARPENTIERE-PÍPOlO, V.; SOUZA, A.; SILVA, D. A.; BARRETO, T. P.; GARBUGLiO, D. D.; FERREIRA, J. M. Avaliação de cultivares de milho crioulo em sistema de baixo nível tecnológico. Acta Scientiarum Agronomy, v. 32, n. 2, p. 229-233, 2010.

[7] CORDEIRO, A. ALMEIDA, P. Semente da Paixão - estratégia comunitária de conservação de variedades locais no semi-árido. 2ª edição. Esperança - PB. AS-PTA, 2002.

[8] CORDEIRO, A. FARIA A. A. Gestão de bancos de sementes comunitários. Rio de Janeiro. AS-PTA, 1993.

[9] DAVIS, D. R. Declining fruit and vegetable nutrient composition: what is the evidence?. HortScience, v.44, n.1, p.15-19, 2009.

[10] FRANÇA, C.; GARCIA, L. Sementes Livres- Ações pela Soberania da Natureza. REDD - Revista Espaço de Diálogo e Desconexão, Araraquara, v.8, n.2. p.01 2014.

[11] GARCÍA, M. C. Experiências brasileiras com sementes crioulas. PESAGRO-RIO, Empresa de Pesquisa Agropecuária do Estado do Rio de Janeiro. p. 05-21, 2004.

[12] LINHARES, J. F. P.; RODRIGUES, M. I. A. O resgate das sementes crioulas como estratégia para conservação da agrobiodiversidade e autonomia na produção camponesa. Revista Pós Ciências Sociais, v.5, n. 9/10, p.205206, 2008.

[13] LONDRES, F. As sementes da paixão e as políticas de distribuição de sementes na Paraíba: Sementes Locais: experiências agroecológicas de conservação e uso Rio de Janeiro : AS-PTA, p. 83, 2014.

[14] NORGAARD, R. B. A base epistemológica da agroecologia. In: ALTIERI, M. A. (Ed.) Agroecologia: as bases científicas da agricultura alternativa. Rio de Janeiro: PTA/Fase, 1989. p.42-8. 
[15] OLIVEIRA, E. L. Conservação de base comunitária de sementes crioulas: a experiência da Casa de Sementes de Barra do Tamboril, Januária/MG, 2009, 132 f. Dissertação (Mestrado). Universidade de Brasília. Faculdade UNB Planaltina, Programa de Pós Graduação em Meio Ambiente e Desenvolvimento Rural. 2014.

[16] PALÁCIO FILHO, A. M.; ARAÚJO, D. V.; CAMPOS, G. P. A.; BORGES, J. M.; ANDRADE, L. P. Oficinas sobre uso de sementes crioulas - Incentivo para produção Agroecológica na região do Agreste Meridional de Pernambuco. Cadernos de Agroecologia, v.6, n.2, p.03, 2011.

[17] QUEIROGA, V. P., SILVA, O. R. F., ALMEIDA, F. A. C. Tecnologias para o desenvolvimento da agricultura familiar: Bancos Comunitários de Sementes. 1.ed. Campina Grande: Fraternidade de São Francisco de Assis / Universidade Federal de Campina Grande, 2011, p. 157.

[18] SARAVALLE, C. Y. Sementes Crioulas: estratégias de resistência camponesa na UNAIC (União das Associações Comunitárias do Interior de Canguçu-RS), Canguçu, Rio Grande do Sul. Cadernos de Agroecologia, v.9, n.4, p. 6, 2014.

[19] SEVILla GUZMÁN, E. Agroecologia e Desenvolvimento Rural Sustentável in Agroecologia - Princípios e técnicas para uma agricultura orgânica sustentável. Brasília. Embrapa, 2005.

[20] SOARES, A.V. \& ALBA, R.P. As sementes crioulas, a festa das sementes e o encontro regional de agroecologia in Anais da 8ª Jornada de Agroecologia - Paraná - Brasil. Francisco Beltrão. 2009.

[21] VASCONCELOS, J. M. G. Práticas Agroecológicas Adotadas pelos Agricultores Familiares do Assentamento Vista Alegre no Semiárido Cearense. 2013, 67 f. Dissertação (Mestrado em Agroecologia e Desenvolvimento Rural). Programa de Pós Graduação em Agroecologia e Desenvolvimento Rural. Universidade Federal de São Carlos- Centro de Ciencias Agrarias, Araras, 2013.

[22] VIDAL, N. W. VIDAL, R. R. Botânica organografia: quadros sinóticos ilustrados de fanerógamos. ed.4., Viçosa: Ed. Da UFV, 2006. 


\title{
Capítulo 15
}

\section{Aspectos biométricos das sementes de Croton Heliotropiifolius kunth (Euphorbiaceae) em um gradiente topográfico no semiárido brasileiro}

\author{
Lúcia Virginia Castor do Rêgo \\ Gilbevan Ramos de Almeida \\ D Ávilla Ruama Fernandes Lopes Gomes \\ Maiara Bezerra Ramos \\ Humberto Araújo Almeida \\ Fabricio Correia Diniz. \\ Sérgio de Faria Lopes
}

Resumo- Estudos relacionados aos aspectos morfológicos e biométricos de sementes são importantes para o entendimento de estratégias adaptativas das plantas à diferentes condições do ambiente. 0 objetivo deste trabalho foi avaliar atributos biométricos das sementes de Croton heliotropiifolius (marmeleiro-branco), ao longo de um gradiente topográfico na região semiárida do Brasil. A coleta de dados foi realizada na Serra da Arara (São João do Cariri-PB). 0 gradiente topográfico foi dividido em três níveis de altitude: nível 1 com elevação entre 470 a 500 metros, nível 2 com elevação entre 501 e 570 metros e nível 3 com elevação $\geq 571$ metros. Para cada nível foram coletadas sementes de pelo menos 30 indivíduos e, em seguida as amostras foram agrupadas em três lotes correspondendo aos níveis de altitude. Para a avaliação biométrica foram mensurados os comprimentos ( $\mathrm{mm}$ ), as larguras ( $\mathrm{mm}$ ) e espessuras ( $\mathrm{mm}$ ) das sementes, com auxílio do paquímetro digital. Para verificar diferenças significativas entre os dados biométricos das sementes nos diferentes níveis de altitude foi aplicado o teste de Kruskal-Wallis e, posteriormente, foram plotados gráficos de distribuição de frequência dos atributos analisados. Os valores médios de comprimento das sementes variaram de $4,90 \mathrm{~mm}$ a $5,53 \mathrm{~mm}$, os de largura de $2,95 \mathrm{~mm}$ a 3,35 $\mathrm{mm}$ e os de espessura variaram de $2,18 \mathrm{~mm}$ a 2,68 mm. Houve diferenças significativas nos atributos das sementes entre os três níveis de altitude avaliados ( $\mathrm{p}<0.05)$. Nossos dados sugerem estratégias adaptativas da espécie, em resposta às mudanças locais ambientais e/ou associados à coexistência com uma biota diferenciada ao longo do gradiente topográfico estudado.

Palavras-Chave: Marmeleiro-branco, Caatinga, Altitude, Adaptações locais. 


\section{INTRODUÇÃO}

Florestas Tropicais Sazonalmente Secas (FTSs) são importantes fitofisionomias de ambientes tropicais (MORO et al., 2016). Na região nordeste do Brasil, a Caatinga compreende uma importante área de FTSs do país, sendo considerada uma das maiores regiões semiáridas no planeta (SILVA et al., 2017). A Caatinga, estende-se por uma área de aproximadamente $900 \mathrm{mil} \mathrm{km²}$ sendo definida como uma vegetação arbustiva e/ou arbórea, com espécies apresentando características xerofíticas, espécies em sua maioria decíduas, dotadas de uma alta variabilidade florística, a qual deriva sobretudo da multiplicidade nas formas de relevo e tipos climáticos (RODAL; SAMPAIO, 2002; TROVÃO et al., 2007; PEREIRA JÚNIOR; ANDRADE; ARAUJO, 2012).

A alta variedade vegetacional, na Caatinga pode ser ainda observada em microescala, em regiões marcadas por gradientes ambientais, por exemplo ao longo de gradientes topográficos, como as serras do semiárido (LIMA; RODAL, 2010), que apresentam formações diferenciadas (COUTINHO, 2006; SANDERS; RAHBECK, 2012) e são consideradas refúgios de diversidade vegetal (SILVA et al., 2014; KARGER et al., 2014; LOPES; RAMOS; ALMEIDA, 2017) em relação às áreas de caatinga circundante.

Dentre a grande diversidade florística da Caatinga, a família Euphorbiaceae tem se destacado em inúmeros levantamentos florísticos e fitossociológicos (OLIVEIRA et al., 2009; TROVÃO et al., 2010; FABRICANTE et al., 2012; MARANGON et al., 2013). Esse grupo possui ampla distribuição na região Neotropical, sendo considerada uma das famílias de maior importância econômica (SÁTIRO; ROQUE, 2008). No Brasil, é encontrada predominantemente no Nordeste, estendendo-se até o estado de Minas Gerais (LUCENA, 2000).

No semiárido nordestino, os gêneros de Euphorbiaceae com maior riqueza de espécie, são Croton, Cnidoscolus, Dalechampia, Euphorbia, Bernardia, Jatropha e Manihot (CREPALDI, 2013). Algumas de suas espécies são citadas muitas vezes como pioneiras, ocupando frequentemente áreas perturbadas, bordas de matas e estradas, afloramentos rochosos e ambientes ruderais (SÁTIRO; ROQUE, 2008; SILVA, et al., 2010).

Os frutos das espécies da família Euphorbiaceae são geralmente do tipo capsular, deiscente, possuindo três lóculos, ou mericarpos que se abrem de forma explosiva e em cada lóculo é encontrado um óvulo (SÁTIRO; ROQUE, 2008). Sementes, compreendem a unidade reprodutiva das espermatófitas, com evolução intrinsecamente associada à dispersão (BELTRATI; PAOLI, 2006). Características morfológicas desses órgãos reprodutivos, tais como o tamanho, estão estritamente associadas ao sucesso reprodutivo das espécies (HOECHEL; OTTE, 2004; CHEIB; GARCIA, 2012). Devido às influências ambientais e a variabilidade genética, durante o desenvolvimento das sementes, essas podem apresentar variações tanto dentro de um mesmo indivíduo, como entre indivíduos de populações de uma mesma espécie (SANTOS et al., 2009; BOGNOUNOU et al., 2010).

Dentre as espécies da família das Euphorbiaceae, o Croton heliotropiifolius Kunth é conhecida popularmente como "velame", "velaminho" e "velaminho de cheiro" (SILVA et al., 2010) e possui maior abundância nas porções inferiores do gradiente topográfico da área de estudo. É uma espécie encontrada em áreas abertas com maior incidência de luz (CREPALDI, 2013) e sempre formando grandes populações em vegetação de Caatinga (SILVA et al., 2010).

A caracterização biométrica de frutos e de sementes tem importância para a taxonomia, na identificação de variedades e para verificar a ocorrência de variações fenotípicas (PINTO et al., 2003), além de refletir adaptações às condições ambientais locais. Diante disso, buscou-se avaliar a variabilidade das características biométricas (comprimento, largura e espessura) das sementes de $C$. heliotropiifolius em um gradiente topográfico no semiárido brasileiro.

\section{MATERIAIS E MÉTODOS}

\section{1 ÁREA DE ESTUDO E AMOSTRAGEM DOS INDIVÍDUOS}

0 estudo foi conduzido na Serra da Arara $\left(07^{\circ} 23^{\prime} 8.12^{\prime \prime}\right.$ S e $36^{\circ} 23^{\prime} 36.74^{\prime \prime}$ 0) localizada no município de São João do Cariri - PB. A serra está situada no Planalto da Borborema, uma das ecorregiões do semiárido brasileiro descrito por Velloso et al., (2002). A região apresenta clima do tipo Bsh' semiárido quente (FRANCISCO et al., 2016), com temperaturas médias anuais de $26^{\circ} \mathrm{C}$. Entre os meses de novembro a janeiro é considerado o período mais quente do ano, e julho a época mais fria, apresentando uma umidade relativa do ar média em torno de 70\% (ANDRADE et al, 2009). Quanto à tipologia do solo, há uma predominância do tipo Luvissolo Crômico (EMBRAPA SOLOS, 2018). 
Figura 1. Mapa de localização da área de estudo, Serra da Arara, São João do Cariri - PB, Brasil.

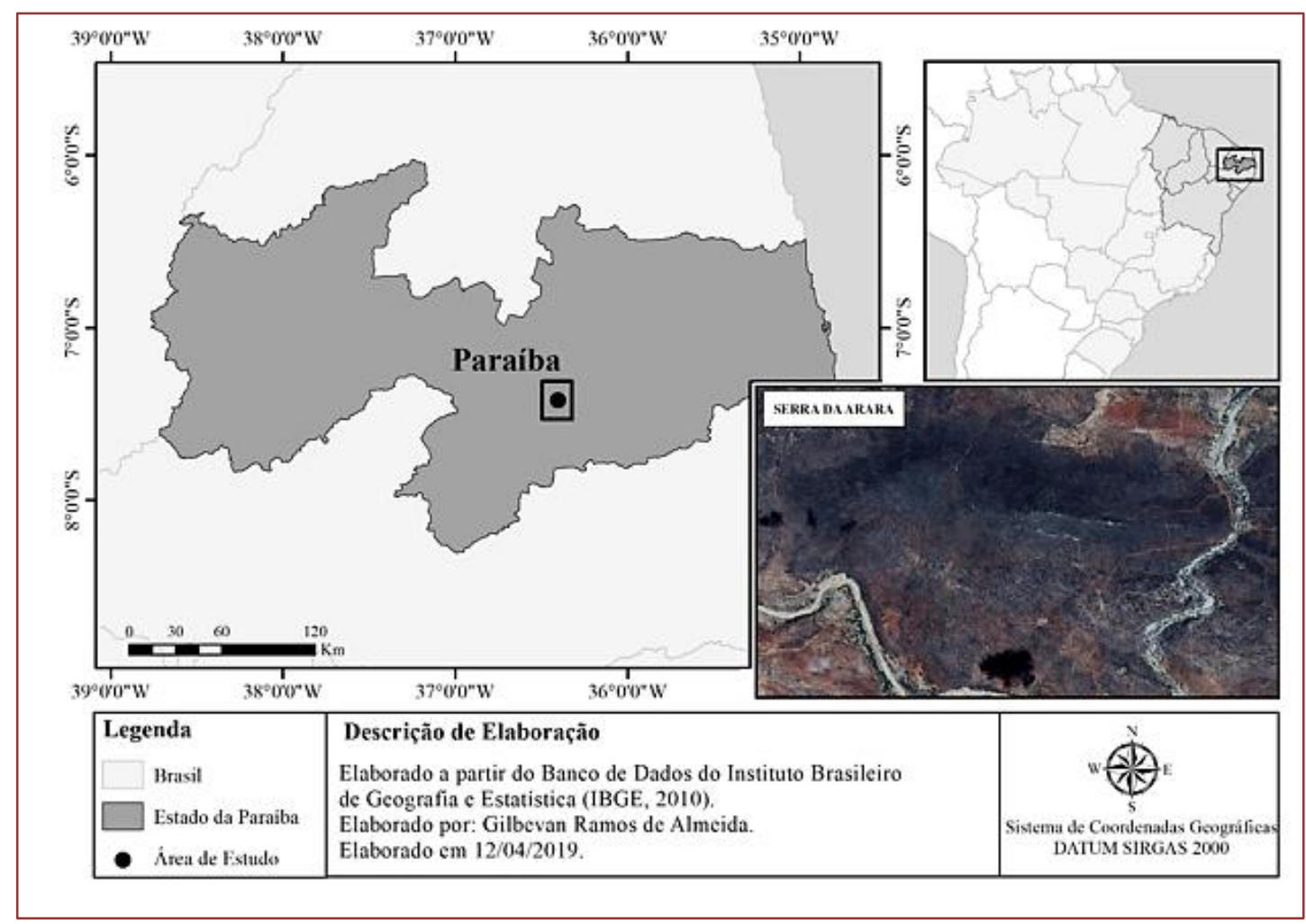

A Serra da Arara possui uma composição de espécies típica de regiões de Caatinga. Na altitude inferior (base da Serra), há um maior número de indivíduos de espécies em estágios iniciais de sucessão ecológica, como o C. heliotropiifolius. A porção inferior da área está susceptível à maior degradação ambiental por ação antrópica, para uso dos recursos, visto que, ocorre à presença de trilhas, uma menor diversidade de espécies, plantas com pequeno porte. Nos níveis superiores a flora é mais diversa, há um aumento na quantidade de rochas e como relação as plantas, nos níveis superiores elas assumem alturas e diâmetro maiores.

Estudos recentes têm demonstrado que ocorrem mudanças na estrutura e composição das comunidades vegetais à medida que se avança no gradiente de altitude. Algumas espécies possuindo ampla distribuição como (Croton blanchetianus Baill, Cenostigma pyramidale (Tul.) Gagnon \& G.P. Lewis, e C. heliotropifolius). Diniz (2016) avaliando a influência de variáveis ambientais na estrutura de comunidades vegetais em um gradiente topográfico no semiárido brasileiro, mostrou que $C$. heliotropiifolius apresenta uma ampla distribuição na área estudada, o que sugere a alta capacidade dessa espécie em colonizar sob variadas condições de micro-habitats.

A Serra da Arara possui uma composição de espécies típica de regiões de Caatinga. Na altitude inferior (base da Serra), há um maior número de indivíduos de espécies em estágios iniciais de sucessão ecológica, como o C. heliotropiifolius. A porção inferior da área está susceptível à maior degradação ambiental por ação antrópica, para uso dos recursos, visto que, ocorre à presença de trilhas, uma menor diversidade de espécies, plantas com pequeno porte. Nos níveis superiores a flora é mais diversa, há um aumento na quantidade de rochas e como relação as plantas, nos níveis superiores elas assumem alturas e diâmetro maiores.

Para coleta dos frutos e sementes, o gradiente topográfico foi dividido em três níveis de altitude com amplitude de 70 m a.n.m, para isso, foi usado um GPS Garmin. Assim, o gradiente altitudinal foi dividido da seguinte forma: nível 1 (N1, base da serra) com elevação entre 470 e 500 m a.n.m, nível 2 (N2, porção intermediária) com elevação entre 501 e 570 m a.n.m e nível 3 (N3, topo da serra) com elevação $\geq 571 \mathrm{~m}$ a.n.m. A divisão em níveis altitudinais favorece uma amostragem de sementes provenientes de vários pais amplamente espaçados, permitindo a inclusão de uma amostra muito mais representativa de genótipos de cada população e, portanto, deve aumentar o realismo ecológico dos resultados (GIANOLI; VALLADARES, 2012). 


\subsection{COLETA E BIOMETRIA DAS SEMENTES}

Foram coletados frutos de $C$. heliotropiifolius, que apresentavam coloração marrom alaranjados no início de queda espontânea, ou seja, maduros. As sementes obtidas de cada um dos níveis altitudinais foram separadas e respectivamente denominadas de acordo com o nível, em: LOTE 1(N1), LOTE 2 (N2) e LOTE 3 (N3). Em cada altitude, os frutos foram obtidos a partir de um mínimo de 30 indivíduos distintos, separados entre si, com distância mínima de 20 metros. Posteriormente, os frutos foram acondicionados em sacos plásticos, etiquetados por LOTES e transportados para o Laboratório de Ecologia e Conservação de Florestas Secas (EcoTropics) da Universidade Estadual da Paraíba - UEPB, Campus I, Campina Grande. As extrações das sementes foram realizadas pela quebra de suas cápsulas, com auxílio de uma pinça, na região do ápice onde se localiza um poro, o qual se abre em septos, que separam os lóculos, onde se desenvolvem as sementes.

A partir de uma amostra de 90 sementes os atributos biométricos foram obtidos. Realizou-se as medições do comprimento longitudinal (mm; medição determinada a partir da base até o ápice), e medições para os atributos largura $(\mathrm{mm})$ e espessura $(\mathrm{mm})$, que foram estimados a partir da linha mediana de cada semente com o auxílio de um paquímetro digital $(0,05 \mathrm{~mm})$ (DUTRA et al., 2017).

\subsection{ANÁLISES ESTATÍSTICAS}

Para cada atributo (comprimento, largura e espessura), foram calculados a média e o desvio padrão dos indivíduos nos níveis altitudinais. Os dados foram classificados por meio de distribuição de frequência e plotados em histogramas de frequência (DUTRA et al., 2017), sendo o número de classes determinado pelo método de Sturges. Por fim, as médias dos atributos biométricos das sementes foram comparadas entre os três níveis de altitude pelo teste de Kruskal-Wallis (nível de confiança de 95\%, p < 0,05). Os dados foram avaliados quanto à sua normalidade por meio do teste de Shapiro-Wilk (HAMMER et al., 2001). Todas as análises foram realizadas utilizando o software Past 2.1 (HAMMER et al., 2001).

\section{RESULTADOS E DISCUSSÃO}

Os valores médios das sementes para comprimento variaram de 4,90 mm (nível 3) a 5,53 mm (nível 2). Os de largura de 2,95 mm (nível 2) a 3,35 mm (nível 1) e os de espessura variaram de 2,18 mm (nível 3) a 2,68 mm (nível 1) (Tabela 1).

Tabela 1. Dados biométricos das sementes de Croton heliotropiifolius Kunth coletadas em um gradiente topográfico na região semiárida da Paraíba. Médias e desvios-padrões (D.P) de comprimento, largura e espessura (mm). As letras minúsculas comparam as médias entre os níveis de altitude. Letras iguais não diferem significativamente, pelo teste de Kruskall-Wallis $(\mathrm{P}>0,05)$.

\begin{tabular}{|c|c|c|c|c|c|c|c|c|c|}
\hline \multirow{2}{*}{ Caracteres das sementes } & \multicolumn{3}{|c|}{ Nível 1 } & \multicolumn{4}{c|}{ Nível 2} & \multicolumn{4}{c|}{ Nível 3} \\
& Média & \pm & D.P & Média & \pm & D.P & Média & \pm & D.P \\
\hline Comprimento & $5,16 \mathrm{a}$ & \pm & 0,41 & $5,53 \mathrm{~b}$ & \pm & 0,45 & $4,90 \mathrm{c}$ & \pm & 0,24 \\
\hline Largura & $3,35 \mathrm{a}$ & \pm & 0,44 & $2,95 \mathrm{~b}$ & \pm & 0,27 & $2,96 \mathrm{~b}$ & \pm & 0,28 \\
\hline Espessura & $2,68 \mathrm{a}$ & \pm & 0,33 & $2,29 \mathrm{~b}$ & \pm & 0,47 & $2,18 \mathrm{~b}$ & \pm & 0,24 \\
\hline
\end{tabular}

Foram obtidas diferenças significativas nos atributos das sementes entre os três níveis de altitudes avaliados (Tabela 1). Para o comprimento, diferenças foram obtidas entre os três níveis de altitude $(p<0,01)$, com menores valores para as altitudes superiores e maiores valores em altitudes intermediárias (Tabela 1). Para largura e espessura, foram observadas diferenças significativas apenas quando comparados o nível 1 em relação aos níveis 2 e $3(\mathrm{p}<0,01)$ (Tabela 1). Essas diferenças encontradas sugerem estratégias adaptativas de indivíduos de $C$. heliotropiifolius em respostas às mudanças ambientais e/ou associados à coexistência com uma biota diferenciada ao longo do gradiente topográfico estudado.

De acordo com Rodrigues e colaboradores (2006), as diferenças biométricas das sementes estão ligadas às condições ambientais, e às respostas da população ao estabelecimento em um novo ambiente, principalmente quando a espécie tem ampla distribuição, como é o caso da espécie aqui estudada.

Especificamente, variações na biometria das sementes dentro de uma espécie está relacionado com as variações do ambiente onde está a planta-mãe (BASKIN; BASKIN, 1998; DUTRA et al., 2017). Exposições da planta-mãe a certos fatores ambientais, como por exemplo, temperatura, estrutura do solo e irradiação solar, podem promover mudanças em suas sementes, e esses determinantes (genéticos ou não genéticos), 
por sua vez, afetam a resposta de germinação e o estabelecimento da plântula (BASKIN; BASKIN, 1998; MARCORA et al., 2013; MARCORA et al., 2017). Consequentemente, as diferenças observadas na biometria das sementes nos indivíduos de $C$. heliotropiifolius entre os níveis de elevação podem refletir adaptações às condições ambientais locais, o que favoreceria o recrutamento em condições análogas das plantasmães.

Os dados relacionados à frequência dos atributos biométricos das sementes estão apresentados na Figura 2. Para a largura e a espessura observou-se que houve uma maior distribuição das sementes nas primeiras classes de tamanho, ou seja, foi obtido um maior número de sementes nas classes de menor tamanho nos atributos estudados (Figura 2). Sementes pequenas são mais eficientes para a captura de água quando comparadas às sementes grandes, devido à maior razão superfície/área (SILVA JÚNIOR et al., 2012). Esta estratégia é vantajosa para espécies de caatinga, já que estão sujeitas à baixa disponibilidade hídrica do ambiente e, portanto, pode favorecer o processo de germinação (BARBOSA, 2003).

Figura 2. Comprimento, largura e espessura ( $\mathrm{mm}$ ) de sementes de Croton heliotropiifolius Kunth, coletados ao longo de um gradiente topográfico, na região semiárida da Paraíba. 0 número acima das barras representa o valor absoluto de sementes.

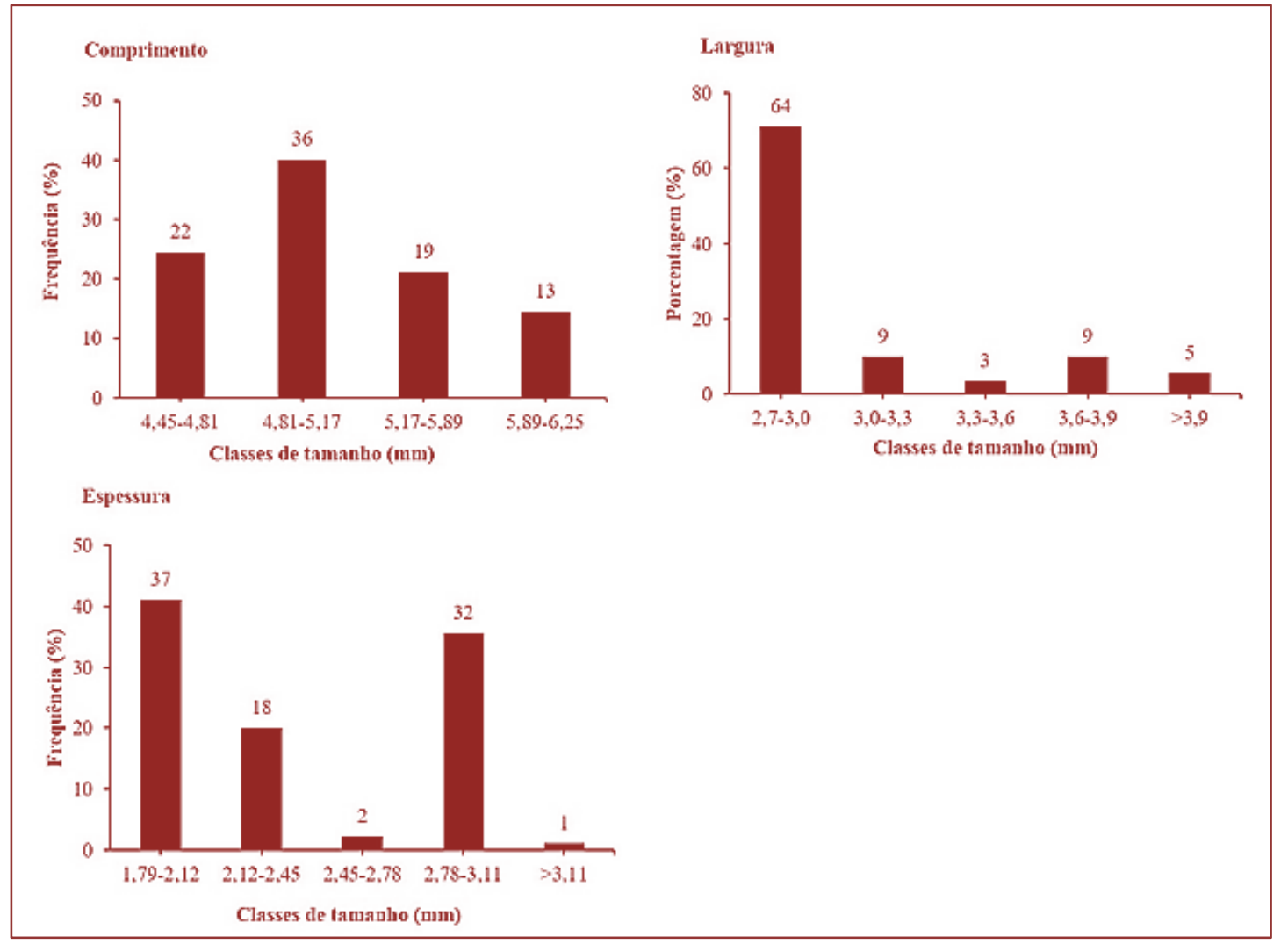

Fica notório que as sementes de $C$. heliotropiifolius além de apresentarem variabilidade ao longo do gradiente topográfico em virtude da plasticidade fenotípica, são pequenas. Tais resultados, refletem à estratégia ecológica da espécie, sendo o $C$. heliotropiifolius uma espécie colonizadora, dotada de características as quais classificamos como secundária inicial, que investe em produção de várias sementes de tamanho pequeno, para seu sucesso reprodutivo (BARBOSA, 2003). Resultados semelhantes foram obtidos por Oliveira-Bento et al. (2013) com a espécie Calotropis procera (flor de seda) em uma área semiárida do nordeste do Brasil.

As condições ambientais variantes encontradas ao longo do gradiente topográfico, são importantes fatores determinantes para que surjam adaptações das espécies em suas características e, em especial para esta análise, as diferenças significativas nos atributos biométricos de $C$. heliotropiifolius são fundamentais para a manutenção da espécie no meio ambiente contrastante. 


\section{CONSIDERAÇÕES FINAIS}

As medidas biométricas das sementes de C. heliotropiifolius apresentaram variabilidade significativa em suas dimensões ao longo do gradiente topográfico, indicando que a espécie apresenta adaptações locais distintas ao longo do gradiente, devido às influências ambientais, importantes para manutenção da espécie em um ambiente variante.

\section{AGRADECIMENTOS}

Agradecemos aos membros do Laboratório de Ecologia e Conservação de Florestas Secas (EcoTropics) pelo suporte em campo, à Sra. Lúcia Verônica Castor do Rêgo (Mãe da primeira autora) pelo auxílio nas análises biométricas, à família Bezerra Ramos pelo suporte prestado, ao Conselho Nacional de Desenvolvimento Científico e Tecnológico (CNPq) pelo apoio financeiro, à CAPES (Coordenação de Aperfeiçoamento de Pessoal de Nível Superior) pelas bolsas cedidas, além disso, agradecemos à Universidade Estadual da Paraíba- UEPB, pelo apoio logístico fornecido para acesso à área estudo.

\section{REFERÊNCIAS}

[1] Andrade, M. V. M. et al. Levantamento florístico e estrutura fitossociológica do estrato herbáceo e subarbustivo em áreas de Caatinga no Cariri paraibano. Revista Caatinga, v. 22, n. 1, 2009.

[2] Barbosa, D.C.de A. Estratégias de germinação e crescimento de espécies lenhosas da Caatinga com germinação rápida. In: LEAL, I.R.; Tabarelli, M.; Silva, J.M.C. da (Ed). Ecologia e Conservação da Caatinga. Recife: Ed. Universitária da UFPE, p. 625-657, 2003.

[3] Baskin, C.S.; Baskin, J.M. Seeds: ecology, biogeography, and evolution of dormancy and germination. Academic Press: London, 1998.

[4] Beltrati, C., \& Paoli, A. Semente. In: Appezzato-da-Glória, B., \& Carmello-Guerreiro, S.M. Anatomia vegetal, 2006.

[5] Bognounou, F. et al. Seed provenance and latitudinal gradient effects on seed germination capacity and seedling establishment of five indigenous species in Burkina Faso. Tropical Ecology, v. 51, n. 2, p. 207, 2010.

[6] Cheib, A.L. \& Garcia, Q.S. Longevity and germination ecology of seeds of endemic Cactaceae species from high-altitude sites in south-eastern Brazil. Seed Science Research 22, 45-52, 2012.

[7] Coutinho, L. M. O conceito de bioma. Acta botânica brasílica. v. 20, n. 1, p. 13-23, 2006.

[8] Crepaldi, C. G. Riqueza e etnobotânica de Euphorbiaceae na Floresta Nacional do Araripe- CE. (Dissertação) 2013

[9] Da Silva, José Maria Cardoso; Leal, Inara R.; Tabarelli, Marcelo (Ed.). Caatinga: the largest tropical dry forest region in South America. Springer, 2018.

[10] De Oliveira-Bento, S. R. S. et al. Biometria de frutos e sementes e germinação de Calotropis procera Aiton (Apocynaceae). Bioscience journal, v. 29, n. 5, 2013.

[11] Diniz, F. C., 2016. Composição e estrutura de comunidades arbustivo/arbóreas ao longo de um gradiente altitudinal no semiárido brasileiro. p. 52. Dissertação (Mestrado em Ecologia e Conservação) - Universidade Estadual da Paraíba.

[12] Dos Santos H. G. et al. Sistema Brasileiro de Classificação de Solos / - 5. ed., rev. e ampl. - Brasília, DF: Embrapa, 2018.

[13] Dutra, V.F. et al. Características Biométricas de Frutos e Sementes de Flamboyant. Sci. Agrar. Paraná, Marechal Cândido Rondon, v. 16, n. 1, p. 127-132, 2017.

[14] Fabricante, J.R.; Andrade, L.A.de; Terceiro, R.G.D., Divergências na composição e na estrutura do componente arbustivo-arbóreo entre duas áreas de caatinga na região do Submédio São Francisco (Petrolina, PE/Juazeiro, BA). Revista Biotemas, 25 (3). 2012.

[15] Francisco, Paulo Roberto Megna et al. Classificação climática de Köppen e Thornthwaite para o estado da Paraíba. Revista Brasileira de Geografia Física, v. 8, n. 4, p. 1006-1016, 2015.

[16] Gianoli, E.; Valladares, F. Studying phenotypic plasticity: the advantages of a broad approach. Biological Journal of the Linnean Society, v. 105, n. 1, p. 1-7, 2012.

[17] Hammer, Ø. et al. PAST: Paleontological Statistics Software Package for education and data analysis. Palaeontolia Electronica 42011. 
[18] Hölzel, N.; Otte, A. Ecological significance of seed germination characteristics in flood-meadow species. FloraMorphology, Distribution, Functional Ecology of Plants, v. 199, n. 1, p. 12-24, 2004.

[19] Karger, D. N.; Weigelt, P.; Amoroso, V. B.; Darnaedi, D.; Hidayat, A.; Kreft, H.; Kessl, M. Island biogeography from regional to local scales: evidence for a spatially scaled echo pattern of fren diversity in the Southeast Asian archipelago. Journal of Biogeography., v. 41, p. 250-260, 2014.

[20] Lima, A. L. A.; RODAL, M. J. N. Phenology and wood density of plants growing in the semi-arid region of northeastern Brazil. Journal of Arid Environments, v. 74, n. 11, p. 1363-1373, 2010.

[21] Lopes, S.F.; Ramos, M.B.; Almeida, G.R. The Role of Mountains as Refugia for Biodiversity in Brazilian Caatinga: Conservationist Implications. Tropical Conservation Science, 10, 1-12, 2017.

[22] Lucena, M. F. A. Estudos taxonômicos do gênero Croton L. (Crotonoideae - Euphorbiaceae) nas zonas do Litoral e da Mata do estado de Pernambuco - Brasil. Dissertação (Mestrado em Botânica) - Universidade Federal Rural de Pernambuco, Recife 2000.

[23] Marangon, G. P.; Ferreira, R.L.C.; Silva, J.A.A.; Lira, D.F. de S.; Silva, E. A.; Loureiro, G. H. Estrutura e padrão espacial da vegetação em uma área de Caatinga. FLORESTA, Curitiba, PR, v. 43, n. 1, p. 83 - 92, jan./mar. 2013.

[24] Marcora, P. I. et al. The effect of altitude and grazing on seedling establishment of woody species in central Argentina. Forest Ecology and Management, v. 291, p. 300-307, 2013.

[25] Marcora, P. I. et al. Influence of altitude on local adaptation in upland tree species from central Argentina. Plant Biology, v. 19, n. 2, p. 123-131, 2017.

[26] Moro, M. F. et al. A Phytogeographical Metaanalysis of the Semiarid Caatinga Domain in Brazil. The Botanical Review, p. 1-58 2016

[27] Oliveira, P. T. B. et al. Florística e fitossociologia de quatro remanescentes vegetacionais em área de serra no Cariri paraibano. Caatinga, Mossoró. v. 22, n. 4, p. 169 - 1782009.

[28] Pereira Júnior, L. R.; Andrade, A. P.; Araujo, K. D. Composição florística e fitossociologia de um fragmento de caatinga em Monteiro, Paraíba. Holos, v. 6, p. 73-87, 2012.

[29] Pinto, W. S. et al. Caracterização física, físico-química e química de frutos de genótipos de cajazeiras. Pesquisa Agropecuária Brasileira, Brasília, v. 38, p. 1059-1066, 2003.

[30] Rodal, M. J. N.; Sampaio, E. V. S. B. A vegetação do bioma caatinga. Vegetação \& Flora de Caatinga: 2002; Recife. Edited by Sampaio EVSB, Giulietti AM, Virginio J, Gamarra-ROJAS CFL, p. 49-90, 2002.

[31] Rodrigues, A.C.C. et al. Biometria de frutos e sementes e grau de umidade de sementes de angico (Anadenanthera colubrina (Vell.) Brenan) procedentes de duas áreas distintas. Revista Científica Eletrônica de Engenharia Florestal, Garça, v.4, n.8, p.1-15, 2006.

[32] Sanders, N. J.; Rahbek, C. The patterns and causes of elevational diversity gradients. Ecography, v. 35, n. 1, p. 1. 2012.

[33] Santos, F.S. et al. Biometria e qualidade fisiológica de sementes de diferentes matrizes de Tabebuia chrysotricha (Mart. ex DC.) Standl. Scientia Forestalis, Piracicaba, v.37, n.82, p.163-173, 2009.

[34] Sátiro L. N.; Roque, N. A família Euphorbiaceae nas caatingas arenosas do médio rio São Francisco, BA, Brasil. Acta Botanica Brasilica, 22:99- 118, 2008.

[35] Silva Junior, V.T. et al., 2012. Erythrina velutina Willd. (leguminosae-papilionoideae) ocorrente em caatinga e brejo de altitude de pernambuco: biometria, embebição e germinação. Revista Árvore, Viçosa-MG, v.36, n.2, p.247-257, 2012.

[36] Silva, F. K. G. et al. 2014. Patterns of species richness and conservation in the Caatinga along elevational gradients in a semiarid ecosystem. Journal of Arid Enviroments, 110, 47-5, 2014.

[37] Silva, J. S. et al. Sinopse das espécies de Cronton L. (Euphorbiaceae) no estado de Pernambuco, Brasil. Acta Botanica Brasilica. 24 (2): 441-453, 2010.

[38] Trovão, D. M. de B. M.; Fernandes, P. D.; Andrade, L. A. de; Dantas Neto, J. Variações sazonais de aspectos fisiológicos de espécies da Caatinga. Revista Brasileira de Engenharia Agrícola e Ambiental, Campina Grande. v. 11, n. 03. p. 307-311, 2007.

[39] Trovão, D. M. B. M.; Freire, A.M.; Melo, J.I.M. de. Florística e fitossociologia do componente lenhoso da mata ciliar do riacho de Bodocongó, semiárido Paraibano. Revista Caatinga, Mossoró, v. 23, n. 2, p. 78-86, abr.-jun., 2010.

[40] Velloso, A. L., E. V. S. B. Sampaio \& F. G. C. Pareyn. Ecorregiões, Propostas para o bioma caatinga. Recife: Associação Plantas do Nordeste, p. 76, 2002. 


\title{
Capítulo 16
}

Reflorestamento de áreas da caatinga no território de identidade de irecê

\author{
Bruna da Silva Gomes \\ Andreza Nunes de Amorim \\ André de Oliveira Alves \\ Cláudio Roberto Meira de Oliveira
}

Resumo: O Território de Identidade de Irecê (TII), atualmente registra cerca de 524.000 hectares de sua vegetação desmatada, esse fenômeno se deu através do uso inadequado dos solos para a produção de culturas agrícolas irrigadas, os quais foram submetidos ao uso de agrotóxicos em grandes quantidades, extração irracional do potencial aquífero subterrâneo e desmatamentos em geral, dessa forma, resultando em áreas improdutivas e vulneráveis à desertificação. 0 presente trabalho tem como objetivo o reflorestamento de áreas em processos de desertificação no (TII) com espécies nativas, frutíferas e exóticas adaptáveis e a mobilização das comunidades das áreas afetadas, visando contribuir com o meio ambiente e a qualidade de vida das pessoas. Os primeiros passos consistiram na realização de campanhas junto à comunidade acadêmica e entorno da universidade, buscando adquirir sementes e recipientes recicláveis para realizar o plantio e posteriormente a distribuição das plantas. Dentre as sementes e mudas plantadas, destacam-se: Pterodon emarginatus, Schinus terebinthifolius, Sideroxylon obtusifolium, Prosopis juliflora, Ziziphus joazeiro, Caesalpinia pyramidalis, Amburana cearensis, Enterolobium contortisiliquum, Tamarindus indica, Mangifera indica, Psidium guajava, Malpighia emarginata, Anacardium occidentale e Spondias tuberosa. Posteriormente, o plantio passou a ser desenvolvido nas residências dos bolsistas, buscando potencializar a proteção das mudas e consequentemente transportado para a Universidade do Estado da Bahia - Campus XVI. Depois dessas etapas, foram realizadas o plantio das mudas em áreas degradadas e em processo de desertificação em diferentes cidades da região de Irecê, assim, combatendo e retardando o processo da degradação ambiental, reequilibrando o meio ambiente e proporcionando uma melhor qualidade de vida aos indivíduos e gerando renda a longo prazo aos pequenos agricultores familiares do TII.

Palavras-chave: Desertificação; Recaatingamento; Sensibilização Ambiental; Meio Ambiente. 


\section{INTRODUÇÃO:}

As áreas suscetíveis à desertificação no Brasil, segundo o Centro de Gestão e Estudos Estratégicos (CGEE), está localizada na região nordeste, incluindo todo o semiárido e áreas do entorno, abrangendo uma superfície de 1.323.975,4 $\mathrm{km}^{2}$ do território brasileiro, de acordo com o Plano Nacional de Combate à Desertificação e Mitigação dos Efeitos da Seca (PAN-BRASIL, 2005) essa área representa $15,72 \%$ do território brasileiro e abriga uma população de 31,6 milhões de habitantes, cerca de 18,65\% da população do País.

A região semiárida tem como atividade econômica principal a agropecuária, que ainda é praticada sob modelos de produção rudimentar, exaurindo cada vez mais os recursos ambientais ainda disponíveis. Com o decorrer do tempo, o uso insustentável dos solos, sobretudo para atingir uma maior produtividade, aliada às variações climáticas, principalmente a irregularidade pluviométrica, teve como resultado uma profunda transformação no sertão nordestino, onde o desmatamento provocou a supressão radical de grande parte do bioma Caatinga, sem levar em conta a fragilidade natural e sua baixa capacidade de recuperação. Na Bahia, as áreas susceptíveis a desertificação, compreende cerca de $26.751,59 \mathrm{~km}^{2}$, o equivalente a 5,44\% do território, os solos do estado mostram-se vulnerabilidade à degradação ambiental e à desertificação, estão erodidos e destituídos dos seus horizontes superficiais (CGEE, 2016).

O Território de Irecê está inserida no semiárido nordestino, localizado no centro-oeste da Bahia, ocupa a zona fisiográfica da Chapada Diamantina Setentrional, possui uma área de $26.730 \mathrm{~km}^{2} \mathrm{com}$ uma população de 418.166, conforme o Plano Territorial de Desenvolvimento Rural Sustentável (PTDRS, 2010). Segundo Nascimento e Gonçalves (2015), a região registra cerca de 524.000 hectares de sua vegetação desmatada, resultante, sobretudo ao processo histórico de exploração dos recursos ambientais.

A trajetória histórica do Território de Identidade de Irecê é marcada pela agropecuária, na década de 1960-1980, houve grandes retiradas da cobertura vegetal para o cultivo das culturas de milho, mamona e principalmente do feijão. Na década de 1990, devido à escassez pluviométrica, a região passou por um processo degradador do uso da terra, com uso maciço de maquinário, implementos agrícolas e extração de água subterrânea. Com o decorrer do tempo esses fatores impactaram negativamente os solos da região, e estas, foram classificadas como susceptíveis à desertificação (MACÊDO, 2010).

De acordo com Miranda (2010), o TII está localizado no Polígono da Seca, caracterizado pela irregularidade pluviométrica, apresentando variações entre 200 a $1.000 \mathrm{~mm}$ por ano. A escassez das chuvas é um dos problemas mais grave enfrentada pela região, pois cada vez mais, a situação da degradação dos solos se intensifica, assim, afetando a produtividade ou a perda total das plantações, propiciando o êxodo rural de pequenos agricultores que tem apenas esta renda para manter suas famílias.

Assim, a necessidade de intensificação de ações intervencionista é imprescindível para retardar e recuperar as áreas degradadas e em processo de desertificação no TII. A atuação da Universidade é fundamental, pois, esta possibilita a formação e capacitação do indivíduo, por meio do embasamento científico/teórico e consequentemente a difusão dos saberes, garantindo a ação transformadora entre a Universidade e a Comunidade, compreendendo em uma integração contributiva entre as partes, dessa maneira, colaborando para o processo de desenvolvimento sustentável na região por meio da disseminação de saberes e ações.

Estas ações, ganham forças, quando há participação e apoio da comunidade e outras entidades locais, como as secretarias de meio ambiente dos municípios que compõem o TII. As mobilizações e colaborações são importantes e urgentes, visto que, é necessário o reestabelecimento do equilíbrio ambiental e a regeneração dos solos no Território de Identidade de Irecê.

0 presente trabalho tem como objetivo o reflorestamento de áreas da Caatinga em processo de desertificação no Território de Identidade de Irecê, com espécies nativas, em especial as frutíferas e as exóticas adaptáveis, assim contribuindo para a recuperação dos solos e melhorando a qualidade de vida dos indivíduos. 


\section{MATERIAIS E MÉTODOS}

- Local do estudo

O estudo foi realizado na Universidade do Estado da Bahia - Campus XVI, pelos discentes vinculados a bolsas de extensão, iniciação científica e contribuição voluntária. Inicialmente foi realizado um estudo bibliográfico, para melhor compreender as áreas susceptíveis à desertificação no Território de Identidade de Irecê e para saber os fatores que acometeram o estado crítico atual dos solos da região.

O TII é composto pelos municípios de América Dourada, Barra do Mendes, Barro Alto, Cafarnaum, Canarana, Central, Gentil do Ouro, Ibipeba, Ibititá, Ipupiara, Irecê, Itaguaçu da Bahia, João Dourado, Jussara, Lapão, Mulungu do Morro, Presidente Dutra, São Gabriel, Uibaí e Xique-Xique (PTDRS, 2010), a localização do Território pode ser observada na figura 1.

Figura 1 - Localização do Território de Identidade de Irecê

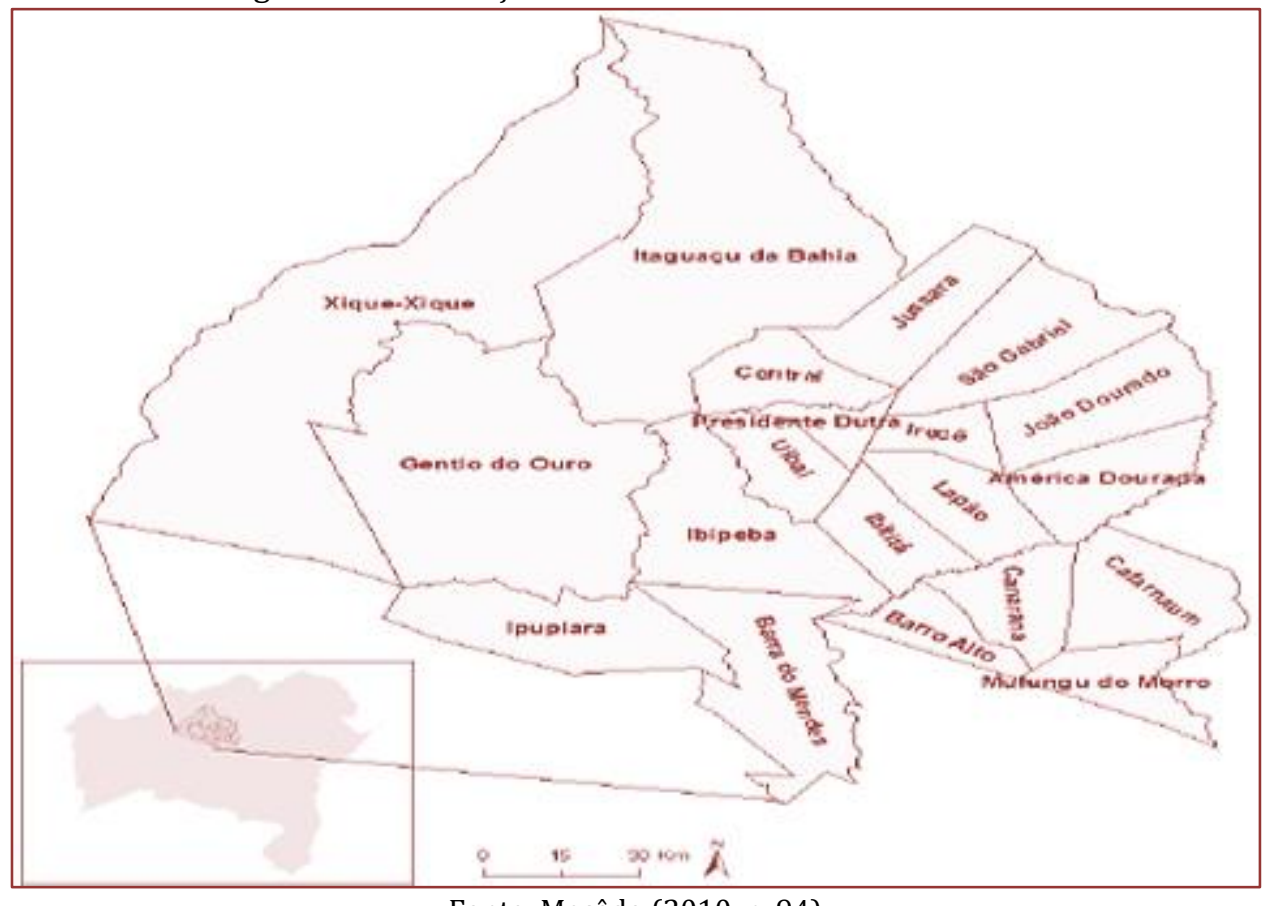

Fonte: Macêdo (2010, p. 94)

Sousa e Sobrinho (2016), explicam que é muito importante utilizar espécies que melhor atendam os prérequisitos determinados, tais como as condições geo-ambientais da região, algumas espécies exóticas, antes apontada como uma das soluções à recuperação das áreas degradadas do semiárido nordestino, podem não serem uma boa escolha, visto que, sua rápida proliferação impedem o desenvolvimento de algumas espécies nativas. Assim, não basta reflorestar, é preciso saber com que reflorestar. No entanto, Lima (2004), comenta que, espécies não endêmicas da Caatinga, como o caso da algarobeira (Prosopis juliflora), apresenta características de invasão, porém, tem apresentado bons resultados de sobrevivência, desenvolvimento e regeneração a curto prazo nas condições geo-ambientais da região semiárida, dessa forma acelerando o processo de recuperação de áreas degradadas principalmente os solos salinizados.

Considerando os autores citados, Sousa e Sobrinho (2016) e Lima (2004), foram realizados estudos iniciais sobre as características gerais da região, como relevo, clima, vegetação predominante, e o agravamento do processo da degradação ambiental no Território de Irecê. Depois desta análise, foram selecionadas as espécies de plantas que se adequam nestas condições e que acelerem o processo de regeneração dos solos, sempre dando ênfase as nativas da Caatinga. Depois desta etapa, ocorreram as campanhas de mobilização interna e externa ao DCHT - Campus XVI, com a finalidade de adquirir doações de sementes, mudas, recipientes recicláveis, tais como: copos descartáveis, embalagens plásticas de alimentos, garrafas pets, e revistas recicláveis para fazer os recipientes moldáveis para a realização do plantio. O substrato "esterco de animais" (suíno, ovino, caprino, bovino) foram doados por pequenos criadores que se sensibilizaram com esta ação. 
Consequentemente, ocorreram os plantios das sementes e mudas doadas pela comunidade, como mostra a figura 2. 0 acompanhamento intensivo foi primordial para uma boa germinação das sementes e desenvoltura das mudas. Com o intuito de potencializar o crescimento das plantas, o cultivo passou a ser realizado nas residências dos bolsistas, estes, moram em cidades diferentes e circunvizinhas a Irecê. Como pode ser observado na figura 2, além dos bolsistas e voluntários vinculados ao projeto, outras pessoas pertencentes à comunidade acadêmica DCHT do Campus XVI, tais como, os técnicos e terceirizados, adentraram nesta ação, contribuindo para a êxito deste trabalho.

Figura 2 - Plantio de mudas realizadas pelos discentes vinculados ao projeto, ambas as fotos foram tiradas no DCHT Campus XVI.

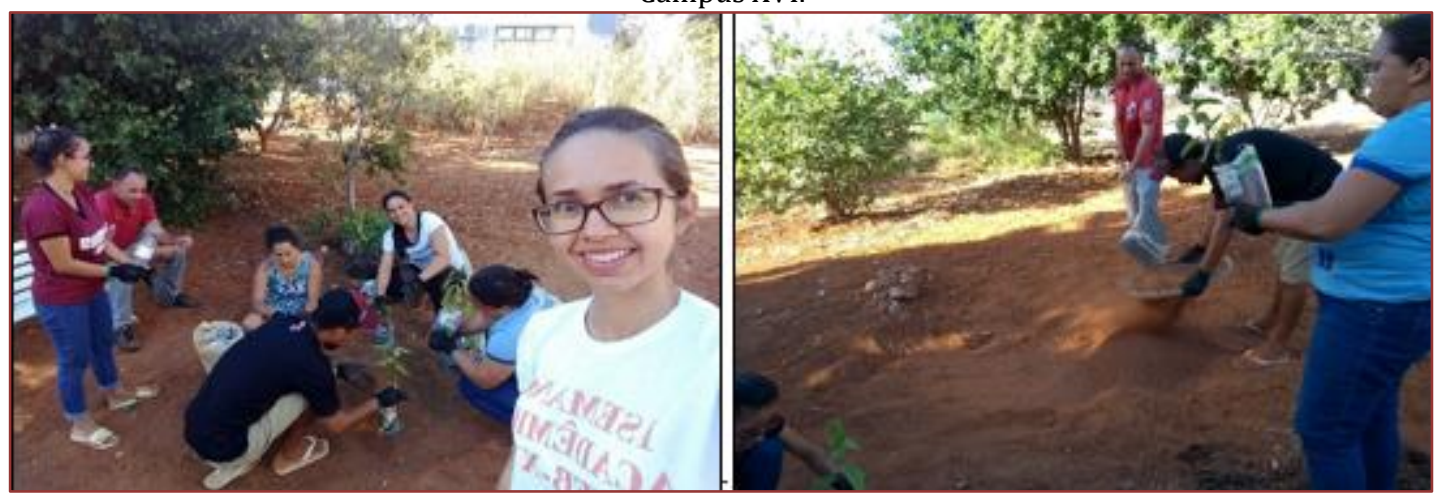

Fonte: Autor do trabalho, 2018.

Depois das mudas bem desenvolvidas, foram doadas aos moradores do Território de Irecê, em especial aos pequenos agricultores. Para garantir o êxito desse trabalho, visitas foram feitas, para o acompanhamento e orientações sobre o bom desenvolvimento das plantas.

\section{RESULTADOS E DISCUSSÃO}

Estudos mostram, que somente no município de Irecê, $90 \%$ da vegetação foi devastada, e a degradação do solo atinge cerca de $78 \%$ do platô da região, nos munícipios circunvizinhos à Irecê, fenômenos geológicos provocaram fissuras no solo, extinção de quase total da Caatinga, assoreamento das margens dos rios, salinização de áreas favoráveis à produção agrícola, contaminação dos recursos hídricos ocasionado pelo uso irracional de agrotóxicos (MIRANDA, 2010).

Diante do exposto, as estratégias utilizadas pelos discentes da UNEB - Campus XVI para combater o processo de degradação dos solos e a desertificação no Território de Identidade de Irecê, foi o reflorestamento com espécies da Caatinga, frutíferas e espécies não endêmica bem adaptáveis à região, sendo possível, mediante a mobilização social.

As espécies de frutas selecionadas para o plantio, além de serem resistentes a secas, possuem um grande potencial econômico, assim, quando transformado em produto acabado, como por exemplo, em doces, geleias, polpas e chás, agregará valor e assim tornando uma fonte de renda extra para os pequenos agricultores familiares da região.

Foram plantadas várias espécies, dentre elas pode-se citar: aroeira (Schinus terebinthifolius), quixabeira (Sideroxylon obtusifolium), juazeiro (Ziziphus joazeiro), caatingueira (Caesalpinia pyramidalis), amburana de cheiro (Amburana cearensis), tamboril (Enterolobium contortisiliquum), tamarindeiro (Tamarindus indica), mangueira (Mangifera indica), goiabeira (Psidium guajava), aceroleira (Malpighia emarginata), cajueiro (Anacardium occidentale), umbuzeiro (Spondias tuberosa) e etc. Em sequência, as mudas bem desenvolvidas, foram distribuídas gratuitamente para os moradores do TII, em especial, aos pequenos agricultores da região e unidades de ensino.

A figura 3, mostra algumas das mudas plantadas na UNEB - Irecê, a maioria das sementes e mudas foram doadas pelos pequenos agricultores que residem próximo ao DCHT - Campus XVI que se sensibilizaram com este trabalho. 
Figura 3 - Plantio das mudas de goiabeira, tamarindeiro, cajueiro, aceroleira e algarobeira (A). Mudas de quixabeira (B). Ambas as fotos tiradas no DCHT - Campus XVI.
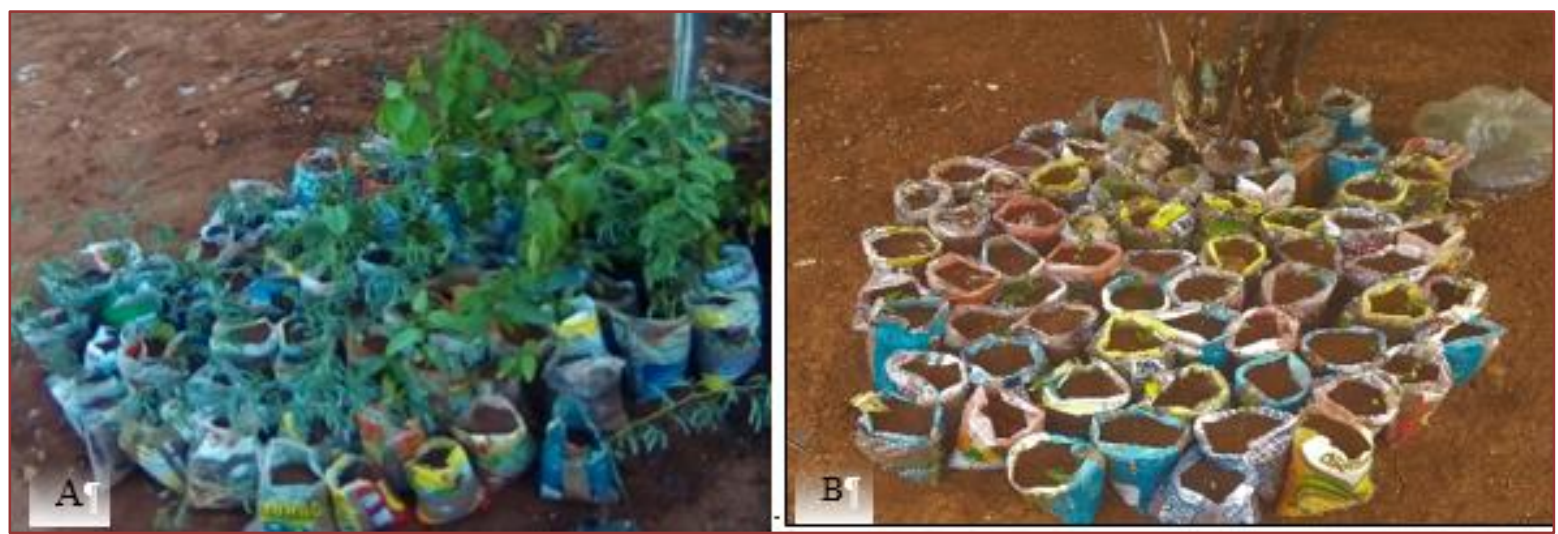

Fonte: Autor do trabalho, 2018.

Lima (2004), Nascimento e Gonçalves (2015), Nepomuceno (2014) dizem que a agropecuária, principalmente a agricultura irrigada e as tecnologias agrícolas usadas no decorrer das últimas décadas, foram os fatores principais para desencadear o desequilíbrio ambiental na região de Irecê. Os autores afirmam que, para reparar os danos causados sobretudo pela ação antrópica, é necessário a recomposição da cobertura vegetal com a adoção de um sistema de plantio que possibilite a escolha de espécies adaptáveis ao bioma local "Caatinga”, dessa forma, recuperando e regenerando os solos degradados, erosivos e salinizados do TII.

Gomes e Soares (2003) diz que a recomposição da vegetação, além de trazer benefícios ao solo, tem um papel importante na purificação do ar, regula sua umidade e temperatura, recicla gases através da fotossíntese. Propicia também um ambiente agradável para os indivíduos. Percebe-se a importância da relação sociedade-natureza, por meio da realização de atividades de preservação e reflorestamento, assim transformando e reequilibrando o meio ambiente.

Assim sendo, espera-se com esse trabalho, a mobilização popular do Território de Irecê, visto que, "essas inciativas ainda são diminutas quando postas em confronto com a forma predominante de exploração da terra na região" (MACÊDO, 2010), porém são essas iniciativas que podem indicar uma perspectiva transformadora na região, mas para isso, precisará de uma ação conjunta, baseada no esforço amplo.

\section{CONCLUSÕES}

Diante da situação da degradação ambiental que o Território de Irecê vem enfrentando, é imprescindível a recuperação dessas áreas com ações que contribuem para a regeneração dos solos e a recomposição da cobertura vegetal. 0 plantio de mudas nativas, frutíferas e exóticas bem adaptáveis ao local, é um bom método para a recuperação das áreas afetadas, pois, retarda e recupera os solos, assim evitando que o processo da desertificação se propague por todo o TII.

Por fim, outro fator primordial para a efetivação dessa ação é a mobilização, conscientização e participação de um número significativo da comunidade do TII, uma vez que, os resultados dessa iniciativa, beneficiará não somente o meio ambiente, mas toda a população residente na região, melhorando a qualidade de vida e gerando renda em longo prazo para os agricultores familiares.

\section{FOMENTO}

Os autores agradecem a Universidade do Estado da Bahia (UNEB) e a Pró-Reitoria de Pesquisa e Ensino de Pós-Graduação (PPG) pelo apoio ao projeto. 


\section{REFERÊNCIAS}

[1] Brasil, Ministério do Desenvolvimento Agrário. Plano de Desenvolvimento Territorial Rural Sustentável de Irecê. Disponível em: <http://sit.mda.gov.br/download/ptdrs/ptdrs_qua_territorio050.pdf>. Brasília, 2010.

[2] Brasil, Programa de Ação Nacional de Combate à Desertificação e Mitigação dos Efeitos da Seca (PAN Brasil). Brasília, DF: Ministério do Meio Ambiente, Secretaria de Recursos Hídricos, 2005.

[3] Cgee, Centro de Gestão e Estudos Estratégicos. Degradação da Terra e Secas no Brasil. Brasília - DF, 2016.

[4] De Sousa, A. J. J.; Sobrinho, A. I. A Importância Do Reflorestamento nos Processos de Recuperação das Áreas Degradadas do Sertão Paraibano. Revista Brasileira de Meio Ambiente e Sustentabilidade-Rebemas, v. 1, n. 1, p. 14-20, 2016.

[5] Gomes, Marcos A. S.; Soares, B. R. A Vegetação nos Centros Urbanos: considerações sobre os espaços verdes em cidades médias brasileiras. Estudos Geográficos, Rio Claro, v. 1, n. 1, p. 19-29, 2003.

[6] Lima, Paulo César Fernandes. Áreas Degradadas: métodos de recuperação no semi-árido brasileiro. XXVII Reunião Nordestina De Botânica, 2004, Petrolina, PE. Anais... Disponível em: < https://www.alice.cnptia.embrapa.br/bitstream/doc/153079/1/OPB406.pdf). Acesso em: janeiro de 2019.

[7] Macêdo, Luiz Rogério de Lima. Dinâmica Socioprodutiva de Territórios Susceptíveis à Desertificação no Estado da Bahia: o caso de Irecê. 2010. Dissertação (Mestrado em Ciências da Terra e do Ambiente) - Universidade Estadual de Feira de Santana (UEFS), Feira de Santana, 2010.

[8] Miranda, Deise Lago de. Universidade do Estado da Bahia/UNEB e o desenvolvimento territorial sustentável: Estudo da relação do campus XVI com o território de identidade de Irecê. Salvador, 2010. Dissertação (Mestrado em Educação) - Programa de Pós-Graduação em Educação e Contemporaneidade - PPGEduC, Universidade do Estado da Bahia, 2010.

[9] Nascimento, Carlos Ney de Oliveira; Gonçalves, João. Neste Dia Mundial de Combate à Desertificação, projeto na região de Irecê na expectativa de recursos do Estado para conclusão. Cultura e Realidade. Irecê, 2015. Disponível em: $\quad$ http://culturaerealidade.blogspot.com/2015/06/neste-dia-mundial-de combate.html?q=desertifica\%C3\%A7\%C3\%A3o>. Acesso em: janeiro 2019.

[10] Nepomuceno, Maurílio Queirós. Análise Geossistémica da Região de Irecê-Ba. 2014. Dissertação (Mestrado em Geografia) - Universidade Federal da Bahia (UFBA). Salvador, 2014. 


\title{
Capítulo 17
}

Disponibilidade e uso de espécies florestais nativas de importância sócioeconômica em comunidades rurais do agreste pernambucano

\author{
José Paulo Feitosa de Oliveira Gonzaga \\ Christianne Torres de Paiva \\ José Fernandes dos Santos Filho
}

Resumo : A gestão dos recursos florestais se constitui, na atualidade, um desafio para o desenvolvimento sustentável, especialmente de pequenas comunidades rurais tais como Mocós e Várzea da Passira localizadas no município de Feira Nova - PE que apresentam poucos remanescentes florestais nativos do bioma Caatinga. Com o objetivo de avaliar a gestão, a disponibilidade e o uso das espécies florestais aroeira (Myracrodruon urundeuva Allemão.) e quixabeira (Sideroxylon obtusifolium (Roem. \& Schult.) T.D. Penn.) nestas comunidades, utilizou-se uma integração de métodos qualitativos e quantitativos em Etnobotânica. Para descrição do perfil socioeconômico e ambiental e inventário etnobotânico foram realizados Diagnóstico Rápido Participativo (DRP) e entrevistas semiestruturadas. O levantamento da vegetação foi realizado através da técnica da Turnê Guiada. Visitou-se 23 propriedades, nas quais foram identificados, georeferenciados e avaliados quanto à estrutura, localização e sinais de exploração, os indivíduos de quixabeira e aroeira com CAP $\geq 5 \mathrm{~cm}$. Observou-se ocorrência destas espécies florestais em $70 \%$ das propriedades visitadas. A maior parte, porém das plantas encontradas apresentavam sinais de corte e /ou retirada de casca. A maioria dos entrevistados demonstrou conhecimento sobre as espécies aroeira e quixabeira, inclusive afirmando que já fizeram uso destas plantas. 0 principal uso indicado é o medicinal, seguido pelo uso madeireiro e na fabricação de cabos de ferramentas. De acordo com os entrevistados, a entrecasca é a parte das plantas utilizada para fins fitoterápicos no caso eventual de pancadas, feridas e inflamações diversas. Os resultados evidenciaram que os saberes acerca do uso das espécies estudadas circulam nas comunidades através do Conhecimento Tradicional Associado, passando de geração em geração, muitas vezes, apenas por via oral. Deste modo, torna-se necessário a realização de ações educativas, além de implementação de estratégias para conservação das espécies estudadas para evitar que o conhecimento local desapareça e que estas espécies voltem a figurar na lista de vulneráveis à extinção.

Palavras-chave: Etnobotânica; Aroeira; Quixabeira; Fitoterápicos; Caatinga. 


\section{INTRODUÇÃO}

A caatinga é um bioma exclusivamente brasileiro que ocupa uma área aproximada de $11 \%$ do território nacional e 80\% do território do Estado de Pernambuco. Cerca de 27 milhões de pessoas vivem nesta região, sendo a maioria carente e dependente dos recursos do bioma para sobreviver (Ministério do Meio Ambiente, 2017; Pareyn, 2010). Apesar da sua importância, o bioma tem sofrido intensa exploração, tendo menos de $2 \%$ de sua área total como área protegida (Leal, Tabarelli \& Silva,2005). Além disso, vale salientar que as estratégias para a conservação ambiental têm predominantemente separado os seres humanos do restante da natureza (Diegues, 2000). Esse modelo não considera, portanto, as populações rurais e, principalmente, as comunidades tradicionais que desenvolvem sistemas de subsistência baseados no uso direto de recursos vegetais e animais nativos, que geralmente são os principais focos da conservação (Hunn, 1999). Neste contexto, torna-se necessário que se enxergue o homem como parte do meio (Gadgil, Berkes \& Folke, 1993) e que sejam consideradas as demandas para sua subsistência no local onde está inserido, bem como a transmissão do conhecimento acumulado entre as gerações acerca do uso dos recursos naturais pelas populações tradicionais.

De acordo com Zuchiwschi (2008), os camponeses e agricultores familiares brasileiros tiveram que se adaptar aos distintos ecossistemas que ocuparam para garantir seu sustento basicamente a partir dos recursos naturais disponíveis, sobre os quais acumularam conhecimento. Peroni, Begossi \& Hanazaki. (2008), afirmam que os agricultores tradicionais possuem um extenso conhecimento sobre plantas e manejo do ambiente em que vivem e a construção desse conhecimento é consequência da produção baseada na subsistência e sua transmissão ocorre via experiência pessoal direta, de forma oral. 0 uso deste conhecimento é validado por sua relevância cotidiana no sistema de subsistência da família. Assim, verifica-se que existe uma interdependência entre o saber popular e a produção de conhecimento (Pereira \& Diegues, 2010).

O conhecimento acumulado no contato de humanos com recursos naturais frequentemente é denominado de "conhecimento ecológico tradicional", termo que faz referência, principalmente, à questão temporal da adaptação e transmissão desse conhecimento entre gerações (Gadgil, Berkes \& Folke, 1993). 0 termo "saber local" também é utilizado para esse tipo de conhecimento, enfatizando, neste caso, o aspecto espacial e seu caráter híbrido, por ser produzido a partir da combinação de elementos naturais, sociais e técnicos muito diversos (Guivant,1997), como propõe a teoria de "actor-network" (Latour,1987) que aponta para uma interdependência entre o conhecimento científico e o local, e para a hibridização ou fusão de horizonte. Vale salientar que o conhecimento, assim como as comunidades ou populações humanas que os detém, é diverso e dinâmico (Padoch \& Dejong, 1992) e está constantemente se adaptando, e novos conhecimentos são continuamente adicionados aos sistemas de conhecimento local e, por serem transmitidos oralmente são vulneráveis às rápidas mudanças. Cunha (1999) ressalta que a ameaça ao saber local não é simplesmente sobre o conhecimento em si, mas sim sobre as condições de produção desse conhecimento.

O conhecimento local sobre o ambiente possui importantes implicações para a conservação e o manejo (Posey, 1983), a despeito de este conhecimento ser tradicional, costumeiro, recente, ou consistente a apenas uma cultura (Begossi \& Hens, 2001). Pereira e Diegues (2010), afirmam que ao articular as características das populações tradicionais e a produção dos seus conhecimentos, tornam-se perceptíveis a relação de dependência entre ambos e a dependência dos mesmos com os recursos naturais.

No bioma Caatinga estão inseridos diversos grupos sociais tradicionais, tais como indígenas e quilombolas que apresentam grande demanda pelos recursos naturais e que os exploram de acordo com sua condição socioeconômica. No entanto, estudos etnobotânicos são escassos nessa região (Almeida \& Albuquerque, 2002), o que confere um caráter de urgência à necessidade da realização de estudos relacionados à gestão, ao uso e aos processos ecológicos da Caatinga (Araújo, Castro \& Albuquerque, 2007) considerando e valorizando os saberes locais.

Em pesquisa realizada por Gomes et al. (2008), nos municípios de Petrolina-PE e Juazeiro-BA, na qual foi feito um levantamento etnobotânico, Foi atestado que a comercialização de diversas espécies vegetais nativas do bioma Caatinga ocorrem em feiras livres. Estas espécies, em geral, são exploradas de forma insustentável uma vez que são comercializadas apenas partes das plantas, tais como casca, raízes, caules e folhas que possuem propriedades fitoterápicas.

Dentre as várias espécies florestais utilizadas tradicionalmente pelas comunidades que estão inseridas no bioma Caatinga, destacam-se a aroeira (Myracrodruon urundeuva Allemão) e a quixabeira (Sideroxylon obtusifolium (Roem. \& Schult.) T.D. Penn.). 
A aroeira (Myracrodruon urundeuva Allemão) e a quixabeira (Sideroxylon obtusifolium (Humb. ex Roem. \& Schult.) T.D. Penn), são espécies abundantes na caatinga, mas chegaram a figurar a lista de espécies ameaçadas de extinção, classificadas como vulneráveis. E, embora na atualidade ambas estejam classificadas como "pouco preocupantes", estudos alertam para o risco de extinção destas espécies em determinadas localidades. (Almeida \& Albuquerque, 2002; Albuquerque \& Oliveira, 2007). Atribui-se essa situação ao modelo de exploração, considerando ainda que as características dessas espécies atraem grande interesse da população local (Pedrosa et al, 2012).

A parte mais utilizada das plantas da Caatinga para preparos de uso medicinal é a casca. Segundo Albuquerque \& Andrade (2002), esse fato pode ser explicado pela ecologia das plantas, enquanto as folhas, flores e frutos só estão disponíveis em períodos chuvosos, que são muito curtos, a casca está disponível o ano inteiro. No entanto, a retirada da casca impõe risco à planta, podendo causar desde um estresse fisiológico até a morte dos indivíduos.

A aroeira (Myracrodruon urundeuva Allemão) é uma das espécies da Caatinga mais ricas em tanino e compostos fenólicos, estando entre as espécies mais citadas para uso medicinal (Araújo; Castro; Albuquerque, 2007). A quixabeira (Sideroxylon obtusifolium (Humb. ex Roem. \& Schult.) T.D. Penn) também é muito utilizada para fins medicinais devido às suas propriedades anti-inflamatórias (Cabral, Peixoto Sobrinho \& Amorim, 2010), sendo ainda utilizada sua madeira devido à resistência e durabilidade.

Em estudo etnobotânico realizado no semiárido paraibano por Marreiros et al. (2015), registrou-se a aroeira (Myracrodruon urundeuva Allemão) como a espécie mais citada para uso medicinal, seguida pela quixabeira (Sideroxylon obtusifolium (Roem. \& Schult.) T.D. Penn.). Estes autores também evidenciaram o uso destas espécies florestais para fins madeireiros e como combustível. Sousa et al. (2012) descrevem em sua pesquisa as diversas formas de utilização da aroeira (Myracrodruon urundeuva Allemão) e da quixabeira (Sideroxylon obtusifolium (Roem. \& Schult.) T.D. Penn.) , variando da utilização medicamentosa, até a fabricação de utensílios e construção de moradia e instalações rurais.

Em trabalho de pesquisa conduzido por Pedrosa et al (2012) evidenciou-se a necessidade da realização de estudos sobre a importância e uso de espécies da Caatinga para as populações tradicionais. Para Albuquerque (1999), as populações tradicionais apresentam modelos de exploração que podem indicar caminhos para o estabelecimento de estratégias e de modelos de gestão sustentáveis que proporcionem a conservação dos ecossistemas. De acordo com Silva (2009), considerando a necessidade da promoção do desenvolvimento sustentável para garantir a fixação do homem no campo e conservação dos recursos naturais, torna-se necessário a adoção de práticas diferenciadas de acordo com o ambiente de modo que a geração de emprego e renda, bem como a preservação ambiental seja consequência do manejo e gestão adequada.

Neste contexto, o presente trabalho se propõe a analisar o uso e disponibilidade dos recursos florestais nativos nas comunidades rurais de Mocós e Várzea da Passira, localizadas no município de Feira Nova (PE). Esta análise enfocou o uso das espécies florestais aroeira (Myracrodruon urundeuva Allemão) e quixabeira (Sideroxylon obtusifolium (Roem. \& Schult.) T.D. Penn.) devido à importância ecológica e econômica destas espécies para as comunidades estudadas.

\section{MATERIAL E MÉTODOS}

\subsection{CARACTERIZAÇÃO DA ÁREA DE ESTUDO}

O estudo foi realizado nas comunidades de Mocós e Várzea da Passira, inseridas no município de Feira Nova. Este município está localizdo na mesorregião do Agreste Pernambucano nas coordenadas geográficas 7o 57' 03" de latitude Sul e 35 23’ 21" de longitude Oeste, em área de transição entre a Zona da Mata e o Agreste (Figura 1).

O clima é do tipo Aw, segundo a classificação climática de Köppen, com chuvas iniciando no período de janeiro - março, podendo se prolongar até outubro (CPRM, 2005), apresentando valores baixos de média pluviométrica (APAC, 2016).

A vegetação é formada por Florestas Subcaducifólias e Caducifólias, próprias das áreas agrestes (CPRM, 2005), caracterizando-se pela presença de plantas arbustivas decíduas e semidecíduas, cactos e bromélias.

O município de Feira Nova possui uma população 20.571, com uma densidade demográfica de 190,96 $\mathrm{hab} / \mathrm{km}^{2}$, sendo a maioria residente na zona urbana (IBGE, 2010) e apresenta um IDH de 0,60 (Programa das Nações Unidas para o Desenvolvimento - PNUD, 2010). 
Nas comunidades rurais de Mocós e Várzea da Passira existem 46 famílias residentes (Programa Saúde da Família, 2016), distribuídas em 23 propriedades rurais que possuem área inferior a 20 hectares, onde a base de sustentação da população local é a agricultura familiar de subsistência.

Figura 1: Localização da área de estudo

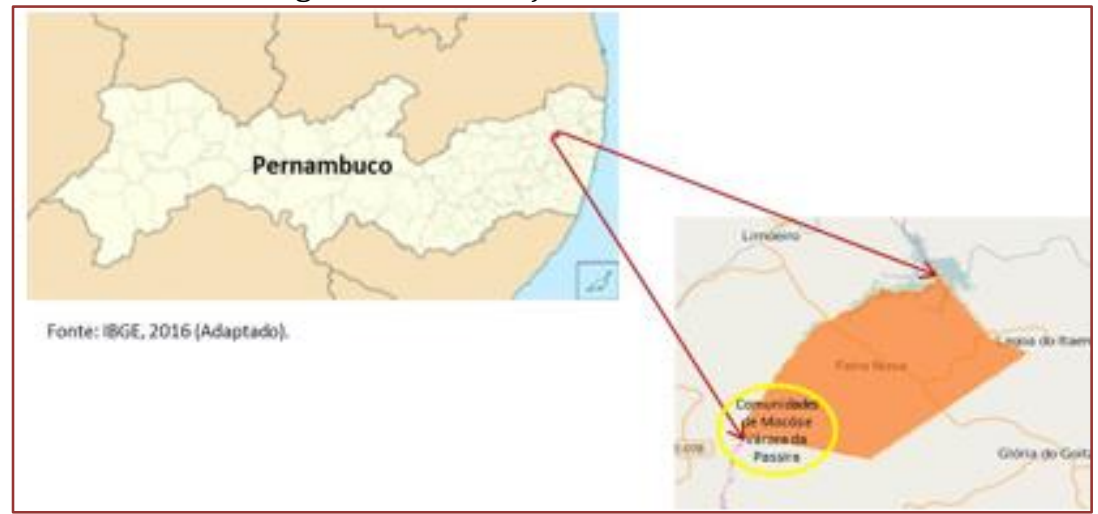

\subsection{COLETA E ANÁLISE DOS DADOS}

Os métodos de coleta de dados foram baseados numa integração de métodos qualitativos e quantitativos em Etnobotânica. Para descrever os sistemas de produção agrícola das comunidades de Mocós e Várzea da Passira (Feira Nova - PE), verificar os fatores mais importantes para a conservação e uso das espécies florestais aroeira (Myracrodruon urundeuva Allemão) e quixabeira (Sideroxylon obtusifolium (Roem. \& Schult.) T.D. Penn.) nas propriedades, utilizou-se a metodologia do Diagnóstico Rápido e Participativo DRP (Faria \& Neto, 2006; Verdejo, 2006).

O DRP consiste em processos de pesquisa a partir das condições e possibilidades dos participantes, baseando-se nos seus próprios conceitos e critérios de explicação. 0 objetivo é fazer com que os próprios participantes analisem a sua situação e valorizem diferentes opções para melhorá-la. 0 uso das metodologias participativas, incluindo o DRP, promove grande avanço no que tange a participação popular, essa prática é imprescindível para promoção da cidadania e estímulo para a construção do desenvolvimento endógeno e participativo. De acordo com Caporal \& Costabeber (1994), o DRP é o método participativo mais adequado para o trabalho com grupos em condições de maior carência, além de contribuir para a redução de custos em ações de extensão rural.

Foram utilizadas entrevistas semiestruturadas (Florentino, Araújo \& Albuquerque, 2007) com questionamentos a respeito do uso de parcelas dos estabelecimentos agropecuários para cultivos de culturas anuais, perenes e pastagens, produção animal, práticas agrícolas utilizadas, disponibilidade de recursos hídricos, fragmentos florestais nativos, conhecimento e uso de recursos florestais, especialmente da aroeira (Myracrodruon urundeuva Allemão) e quixabeira (Sideroxylon obtusifolium (Roem. \& Schult.) T.D. Penn.) . O questionário foi aplicado considerando um representante da família em cada propriedade que assinou o Termo de Consentimento Livre e Esclarecido em conformidade com o Comitê de Ética em Pesquisa do Conselho Nacional de Saúde (Resolução 196/96).

O levantamento da vegetação foi realizado a partir da técnica da turnê guiada (Alburquerque et al, 2010; Pedrosa et al., 2012; Gomes et al., 2016). Foram registradas todas as plantas das espécies quixabeira (Sideroxylon obtusifolium (Roem. \& Schult.) T.D. Penn.) e aroeira (Myracrodruon urundeuva Allemão) com circunferência à altura do peito (CAP) maior ou igual a $5 \mathrm{~cm}$. 0 CAP foi medido com auxílio de fita métrica a $1,30 \mathrm{~m}$ de altura do solo.

As plantas identificadas foram georeferenciadas conforme Leite (1999) e em cada uma delas foram feitos registros acerca da presença ou ausência de marcas de corte e/ou retirada da casca.

0 estudo foi realizado no período de dezembro de 2016 a maio de 2017, com realização de 16 horas de caminhadas, em roçados, pastagens, quintais, capoeiras, áreas com cobertura vegetal, margens de riachos e estradas locais.

Os resultados obtidos foram devidamente tabulados e analisados considerando os parâmetros fitossociológicos de Densidadade Absoluta (DA), Frequência Absoluta (FA) e Valor de Uso (VU). 
O cálculo da Densidade Absoluta (DA) e Frequência Absoluta (FA) foi feito conforme Vedruscolo et al. (2017).

A Densidade Absoluta (DA) indica o número de indivíduos de determinada espécie por unidade de área (ha) e foi calculada através da expressão:

$\mathrm{DAi}=\mathrm{Ni} / \mathrm{A}$

Onde: $\mathrm{Ni}$ = número de unidades da espécie $\mathrm{i}$;

$\mathrm{A}=$ área total amostrada (ha).

A Freqüência Absoluta (FA) é a porcentagem de propriedades com a ocorrência da espécie em relação ao número total de propriedades visitadas, e foi calculada através da expressão:

$\mathrm{FAi}=(\mathrm{Pi} \times 100) / \mathrm{P}$

Onde: $\mathrm{Pi}$ = número de propriedades nas quais a espécie ocorreu;

$\mathrm{P}=$ número total de propriedades.

O Valor de Uso (VU) foi calculado conforme Rossato, Leitão-Filho \& Begossi (1999), considerando o número de citações de uso mencionado por cada informante, ressaltando-se que o tipo de uso é contado apenas uma vez, como por exemplo: o uso medicinal é contado apenas uma vez, ainda que sejam citadas várias enfermidades tratadas. Utiliza-se a expressão abaixo para o cálculo do VU.

$\mathrm{VU}=\Sigma \mathrm{U}_{\mathrm{i}} / \mathrm{n}$

Onde: $\mathrm{U}_{\mathrm{i}}=$ Número de citações de uso mencionado por cada informante.

$\mathrm{n}=$ Número total de informantes, $\mathrm{n}=23$

Utilizou-se o software Microsoft Excel® para tabulação e análise dos dados.

\section{RESULTADOS E DISCUSSÃO}

\subsection{PERFIL SOCIOECONÔMICO E AMBIENTAL DAS COMUNIDADES MOCóS E VÁRZEA DA PASSIRA}

As comunidades Mocós e Várzea da Passira são vizinhas e estão localizadas na área rural do município de Feira Nova (PE). Estas comunidades possuem perfil socioeconômico e ambiental semelhante. Em ambas as comunidades, predomina a agricultura familiar com propriedades que possuem área variando entre 1 a 51 hectares.

Foram visitadas 23 propriedades rurais, totalizando uma área de 236,3 ha. Em $48 \%$ destas residem mais de uma família. No entanto, em cada propriedade foi entrevistado apenas um representante dos moradores locais, considerado pelos demais como responsável pela propriedade, sendo 12 do sexo masculino e 11 do sexo feminino. A maioria (70\%) dos entrevistados residia na comunidade há mais de 30 anos e havia recebido a propriedade como herança (52\%).

Com relação à escolaridade, a maioria (52\%) dos entrevistados possuía apenas o Ensino Fundamental I incompleto e cerca de $9 \%$ eram analfabetos. Este baixo nível de escolaridade possui reflexos na gestão de recursos florestais, o que foi atestado por Silva et al (2016), que afirmam ser a educação um fator fundamental para a gestão dos recursos florestais e promoção do desenvolvimento sustentável. Pesquisa realizada por Silva et al (2012) ressalta que o cultivo e uso de plantas medicinais apresentou relação inversamente proporcional ao nível de escolaridade.

Na produção agropecuária predomina o cultivo dos produtos de subsistência, destacando-se o plantio de milho e feijão e a criação de gado bovino e aves de corte. Considerando a percepção ambiental dos entrevistados, $87 \%$ declararam que a forma de produção agropecuária utilizada na propriedade não provocaria nenhum impacto ambiental, embora utilizem práticas danosas ao meio ambiente como queimadas, uso de agrotóxicos, adubação química e plantio sem uso de nenhuma técnica de manejo e conservação do solo.

Embora a maioria (77\%) das propriedades possua áreas com cobertura vegetal nativa, verificou-se que esta cobertura está bastante antropizada, sendo frequente a presença de animais que pastam nestas áreas.

$\mathrm{Na}$ área de estudo, existe penas um riacho temporário denominado Riacho Cotunguba que atravessa algumas propriedades localizadas na comunidade Várzea da Passira. As principais fontes hídricas são os 
açudes e cisternas, presentes em $57 \%$ e $65 \%$ das propriedades, respectivamente. Constatou-se que a seca é o maior desafio enfrentado para a produção agropecuária, sendo citada por $61 \%$ dos entrevistados.

\subsection{INVENTÁRIO ETNOBOTÂNICO}

$\mathrm{Na}$ área de estudo, constatou-se que existem poucos remanescentes da vegetação original. Algumas espécies vegetais tem sua população reduzida, é o caso da aroeira (Myracrodruon urundeuva Allemão) e da quixabeira (Sideroxylon obtusifolium (Roem. \& Schult.) T.D. Penn.). Através da técnica da Turnê Guiada, verificou-se que em toda a área de estudo foram catalogados apenas 57 indivíduos de aroeira (Myracrodruon urundeuva Allemão) com densidade absoluta de 0,241 indivíduos de aroeira/ha, com uma frequência absoluta de 76\%. E, foram encontrados 24 indivíduos de quixabeira (Sideroxylon obtusifolium (Roem. \& Schult.) T.D. Penn.) com densidade absoluta de 0,102 indivíduos de quixabeira/ha e uma frequência absoluta de 70\%. Estes resultados evidenciam maior presença da aroeira em relação à quixabeira. Provavelmente, isso decorre do fato da quixabeira ter recebido maior pressão para abastecer a demanda medicinal ou para outros usos, de forma secundária, o que pode ser corroborado pela pesquisa desenvolvida por Pedrosa et al. (2012).

Ambas as plantas podem ser encontrada nas propriedades em áreas com cobertura vegetal nativa, sendo encontradas também em áreas utilizadas como pastagens e cercas.

Verificou-se a ocorrência da aroeira (Myracrodruon urundeuva Allemão) em 87\% das propriedades. Os indivíduos observados estavam em vários estágios de desenvolvimento, com CAP variando de 5 a $125 \mathrm{~cm}$. Apenas 26\% destes indivíduos não apresentavam sinais de exploração. Os demais apresentaram sinais de corte antigo e rebrotamento (49\%), retirada de casca (16\%) e corte recente (9\%) (Figura 2).

Figura 2: Registro de corte e retirada recente de casca da aroeira (Myracrodruon urundeuva Allemão) nas comunidades de Mocós e Várzea da Passira, Feira Nova - PE.

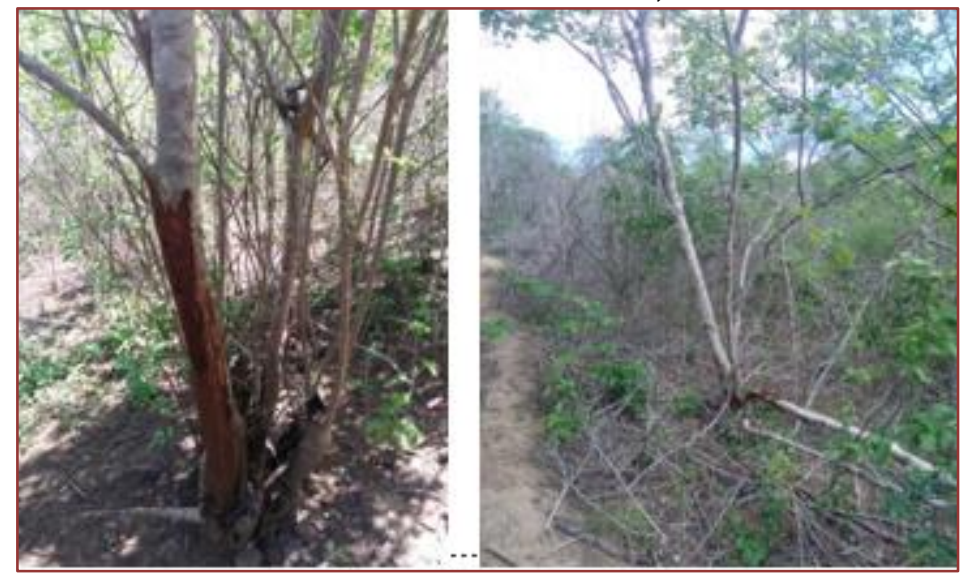

Fonte: Gonzaga, 2017.

A quixabeira (Sideroxylon obtusifolium (Roem. \& Schult.) T.D. Penn.) estava presente em $70 \%$ das propriedades visitadas. Foram localizados 24 indivíduos com CAP variando de 6,5 a $57 \mathrm{~cm}$. Nesta planta, observou-se que a forma de exploração mais utilizada é o corte de galhos para a posterior retirada da casca. Verificou-se que $71 \%$ das plantas apresentavam sinais de corte e /ou retirada de casca (Figura 3). 
Figura 3: Registro de retirada de casca e localização de quixabeira (Sideroxylon obtusifolium (Roem. \& Schult.) T.D. Penn.) nas comunidades de Mocós e Várzea da Passira, Feira Nova - PE .

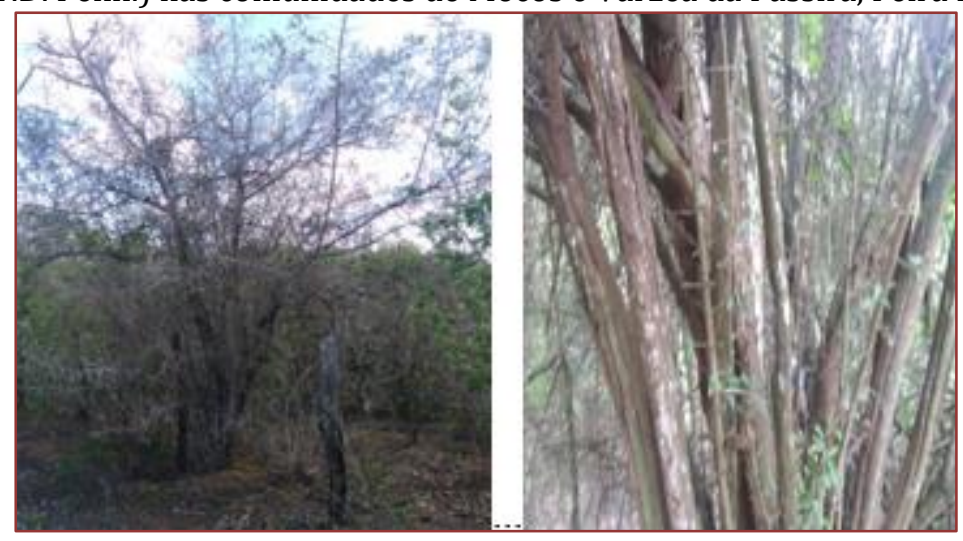

Fonte: Gonzaga, 2017.

Considerando os aspectos relacionados ao uso da aroeira (Myracrodruon urundeuva Allemão), verificou-se que esta planta é reconhecida por $83 \%$ dos entrevistados e $65 \%$ destes afirmaram já ter utilizado a planta. $\mathrm{O}$ uso para fins medicinais destacou-se com 18 citações. Foi citado ainda o uso para fins madeireiros (4), combustível (1) e para a confecção de cabos de ferramentas agrícolas e domésticas (2). No entanto, vale ressaltar que $17 \%$ dos entrevistados afirmaram não conhecer nenhum uso para a espécie. Considerando o uso medicinal, o uso para tratamento de inflamações diversas recebeu 9 citações, seguido pelo uso para tratamento de feridas cutâneas (9 citações). Destaca-se ainda o uso para tratamento de inflamações no aparelho genital feminino (4 citações). 0 tratamento de inflamações bucal e gastrite receberam uma citação cada.

E, no que concerne ao conhecimento acerca da quixabeira (Sideroxylon obtusifolium (Roem. \& Schult.) T.D. Penn.), $87 \%$ dos entrevistados sabiam identificar a planta e $61 \%$ afirmaram que já a utilizaram pelo menos uma vez. 0 uso medicinal recebeu 20 citações, seguido pelo uso para fabricação de cabos de ferramentas (tecnologia) com quatro citações. Já o uso madeireiro recebeu apenas uma citação. Foram citadas seis usos fitoterápicos para esta planta: pancada (5 citações), feridas (6 citações), inflamações diversas (13 citações), inflamação do aparelho genital feminino (3 citações), gastrite (1 citação) e inflamação renal (1 citação). A entrecasca foi a parte da planta citada por todos os entrevistados, em se tratando do uso medicinal.

A partir das citações acerca do uso das espécies florestais estudadas, verificou-se que o valor de uso (VU) para a aroeira (Myracrodruon urundeuva Allemão) foi um pouco maior que o da quixabeira (Sideroxylon obtusifolium (Roem. \& Schult.) T.D. Penn.), correspondendo a respectivamente ao VU =1,22 e VU = 1,13. Vale ressaltar que para a maior parte das recomendações de uso medicinal, os entrevistados afirmaram que a utilização da quixabeira (Sideroxylon obtusifolium (Roem. \& Schult.) T.D. Penn.) está associada ao uso da aroeira (Myracrodruon urundeuva Allemão). Este fato pode ser visto como algo positivo, uma vez que duas espécies florestais, de uma mesma região, sendo utilizadas para o mesmo fim pode diminuir a pressão sobre ambas as espécies de acordo com estudos desenvolvidos por Santoro (2015).

Em se tratando da origem do conhecimento sobre o uso das espécies florestais estudadas, observou-se que a dinâmica de transmissão do conhecimento popular segue o padrão de "transmissão vertical", sendo repassada de uma geração para outra, seja entre membros da mesma família ou por pessoas da comunidade identificadas como especialistas (Roque, Rocha \& Loiola, 2010; Silva et al, 2012). Deste modo, $59 \%$ dos entrevistados afirmaram ter aprendido sobre o uso da quixabeira (Sideroxylon obtusifolium (Roem. \& Schult.) T.D. Penn.) e/ou aroeira (Myracrodruon urundeuva Allemão) com membros da família e $27 \%$ com membros da comunidade.

O conhecimento etnobotânico acerca da aroeira (Myracroduon urundeuva Allemão) e quixabeira (Sideroxylon obtusifolium (Roem. \& Schult.) T.D. Penn) destacados no presente estudo, podem ser corroborados pelos estudos desenvolvidos por diversos pesquisadores (Pedrosa et al, 2012; Sousa et al, 2012; Marreiros et al., 2015; Albuquerque \& Andrade,2002; Almeida \& Albuquerque, 2002). 0 uso medicinal aparece com destaques nas citações. 


\section{CONSIDERAÇÕES FINAIS}

Considerando a necessidade de promover a geração de renda, fixação do homem em seu meio natural e a preservação dos recursos naturais, sobretudo em biomas como a Caatinga,a gestão dos recursos florestais nativos pode ser considerada um divisor de águas no que tange à promoção do desenvolvimento sustentável .

Nas comunidades de Mócos e Várzea da Passira, localizadas no município de Feira Nova (PE), não foram encontrados remanescentes florestais primários. Todas as áreas com vegetação encontram-se antropizadas. A pouca vegetação existente é resultante da regeneração de áreas que foram anteriormente desmatadas para prática de atividades de agropecária. Algumas destas áreas foram abandonadas pelo encerramento das atividades, diminuição da produtividade ou mudança de propriedade possibilitando a regeneração natural. Provavelmente, essa realidade decorre de fatores como pequeno tamanho da propriedade, grande número de famílias residentes e o baixo nível de escolarização dos moradores, associados à necessidade de geração de renda e ausência de políticas públicas voltadas à promoção do desenvolvimento sustentável e gestão dos recursos florestais. Nestas comunidades, os remanescentes florestais são explorados como fonte de medicamentos naturais, madeira e lenha, para uso na propriedade e comercilização, excetuando-se a atividade madeireira que é apenas para uso local.

As espécies aroeira (Myracroduon urundeuva Allemão) e quixabeira (Sideroxylon obtusifolium (Roem. \& Schult.) T.D. Penn) ocupam papel de destaque nas comunidades estudadas. Considerando o uso e importância destas espécies para estas comunidades, verificou-se que a população destas espécies está reduzida e existe uma grande demanda de uso local, indicando que as espécies estão sob pressão. Isto deve servir de alerta para que se considere o risco de desaparecimento das espécies a nível local. Por outro lado, observa-se esse cenário como uma oportunidade para o desenvolvimento de políticas e estratégias voltadas à conservação das espécies que incluam e valorizem saber popular.

Outra importante questão a ser considerada é que os saberes circulam nas comunidades através do Conhecimento Tradicional Associado, passando de geração em geração, muitas vezes apenas por via oral. Este fato evidencia a necessidade da realização de ações educativas (ensino formal e não formal) a fim de evitar que o conhecimento local desapareça e que as políticas e estratégias de conservação sejam eficazes.

\section{REFERENCIAS}

[1] Albuquerque, U. P.; Andrade, L. H. C. Uso dos recursos vegetais da caatinga: O caso do Agreste do estado de Pernambuco (Nordeste do Brasil). Interciencia, 27(7), 336-347, 2002.Disponível em: http://www.redalyc.org/html/339/33907002/

[2] Albuquerque, U. P. La importancia de los estudios etnobiologicos para estabilecimiento de estrategias de manejo y conservación em las florestas tropicales. Biotemas.12(1), 31-47, 1999.Disponível em: https://periodicos.ufsc.br/index.php/biotemas/article/view/21903

[3] Albuquerque, U.P.; Oliveira, R.F. Is the use-impact on native caatinga species in Brazil reduced by the high species richness of medicinal plants? Journal of Ethnopharmacology. 113, 156-170, 2007.Disponível em: http://www.sciencedirect.com/science/article/pii/S0378874107002711

[4] Almeida, C. F. C. B R.; Albuquerque, U. P. Uso e conservação de plantas e animais medicinais no Estado de Pernambuco (Nordeste do Brasil): um estudo de caso. Interciencia, 27(6), 276-285, 2002.Disponível em: http://www.redalyc.org/html/339/33906902/

[5] APAC - Agencia Pernambucana de Águas. Monitoramento pluviométrico. Disponível em http://www.apac.pe.gov.br/meteorologia/monitoramento-pluvio.php. Acesso em 14 de outubro de 2016.

[6] Araujo, E.L.; Castro, C.C.; Albuquerque, U.P. Dynamics of Brazilian Caatinga - A Review Concerning the Plants, Environment and People. Functional Ecosystems and Communities 2007 Global Science Books. 1(1), 15-28, 2007.

Disponível

em:

https://www.researchgate.net/profile/Cibele_Castro2/publication/282363215_Dynamics_of_Brazilian_Caatinga__A_Review_Concerning_the_Plants_Environment_and_People/links/560e97a608ae0fc513ed8d5e/Dynamics-ofBrazilian-Caatinga-A-Review-Concerning-the-Plants-Environment-and-People.pdf.

[7] Begossi, A.; Hens, L. Introduction and acknowledgements. Environment, Development and Sustainability, 2 (3-4), 173-176, 2001. Disponível em: https://www.researchgate.net/profile/Alpina_Begossi/publication/225689294_Diversity_and_management_From_ex tractive_to_farming_systems/links/0a85e53cd39443e25b000000.pdf

[8] Berkes, F. Sacred ecology. Philadelphia: Taylor and Francis, 1999. 210 p. 
[9] Berkes, F.; Folke, C.; Gadgil, M. Traditional ecological knowledge, biodiversity, resilience and sustainability. In: Perrings, C.S. et al. (eds.). Biodiversity conservation. Problems and policies. Dordrecht: Kluwer Academic Press. 1995. p.281-300

[10] Cabral, D. L. V; Peixoto - Sobrinho, T. J. S; Amorim, E. L. C. Relationship of biometric parameters on the concentration of tannins in two medicinal plants - a case study. Boletín Latinoamericano y del Caribe de Plantas Medicinales y Aromáticas, 9 (5), 368 - 376, 2010. Disponível em: http://www.redalyc.org/html/856/85615225008/

[11] Caporal, F.R; Costabeber, J. A. Por uma Nova Extensão Rural: Fugindo da obsolescência. Extensão Rural, 2, 07 26, 1994.Disponível em: https://periodicos.ufsm.br/extensaorural/article/view/6376/3863

[12] CPRM - Serviço Geológico do Brasil. Projeto cadastro de fontes de abastecimento por água subterrânea. Diagnóstico do município de Feira Nova, estado de Pernambuco. Recife: CPRM/PRODEEM, 2005.

[13] Cunha, M. C. Populações tradicionais e a conservação da biodiversidade. Estudos Avançados, 13(36), 147164, 1999.Disponível em: http://www.scielo.br/scielo.php?pid=S0103-40141999000200008\&script=sci_arttext

[14] Diegues, A. C. A etnoconservação da natureza. In: (Org.). Etnoconservação: novos rumos para a proteção da natureza nos trópicos. 2. ed. São Paulo: Hucitec e NUPAUB, p. 1-46, 2000.

[15] EMBRAPA. Zoneamento Agroecológico do Estado de Pernambuco. Disponível em: <http://www.uep.cnps.embrapa.br/zape/cartas/Limoeiro.pdf>. Acesso em 20 de Setembro de 2016.

[16] Faria, A. A. de C; Neto, P. S. F. Ferramentas do diálogo - qualificando o uso das técnicas do DRP: diagnóstico rural participativo. Brasília: Ministério do Meio Ambiente. Instituto Internacional de Educação no Brasil, 2006.

[17] Florentino, A. T. N.; Araújo, E. L.; Albuquerque, U.P. Contribuição dos quintais agroflorestais na conservação das plantas da Caatinga, Município de Caruaru, PE, Brasil. Act. Bot. Bras. 21(01), 37 - 47, 2007. Disponível em: http://www.scielo.br/pdf/\%0D/abb/v21n1/05.pdf

[18] Gadgil, M.; Berkes, F.; Folke, C. Indigenous knowledge for biodiversity conservation. Ambio, 22, (2-3), 151156, 1993.Disponível em: http://www.jstor.org/stable/4314060

[19] Guivant, J.S. Heterogeneidade de Conhecimentos no Desenvolvimento Rural Sustentável. Cadernos de Ciência e Tecnologia,14 (3), 412-447, 1997.Disponível em: https://seer.sct.embrapa.br/index.php/cct/article/view/8979.

[20] Gomes, E. C. S., et al., Plantas da caatinga de uso terapêutico. Levantamento etnobotânico. Engenharia Ambiental, $\quad 5 \quad$ (2), 074-085, 2008.Disponível $\quad$ em: http://ferramentas.unipinhal.edu.br/engenhariaambiental/viewarticle.php?id=130\&layout=abstract\&loc

[21] IBGE - Instituto Brasileiro DE Geografia E Estatística. IBGE cidades. Disponível em: http://www.cidades.ibge.gov.br/xtras/perfil.php?lang=\&codmun=260540. Acesso em 06 de junho de 2016.

[22] Hunn, E.S. The value of subsistence for the future of the world. In: Nazarea, V.D. (ed.). Ethnoecology: situated knowledge/located lives. Arizona: The University of Arizona Press. 1999.

[23] Latour, B. Science in action: how to follow scientists and engineers through society. Cambridge: Harvard University Press. 1987.

[24] Leal, I. R.; Tabarelli, M.; Silva, J. M. C. (Org). Ecologia e conservação da caatinga. Recife: Editora Universitária da UFPE, 2. ed. 2005.

[25] Leite, U. T. Análise da estrutura fitossociológica do estrato arbustivo-arbóreo de duas tipologias de Caatinga ocorrentes no município de São João do Cariri- PB. Areia. Monografia (Graduação em Agronomia) - UFPB, 1999.

[26] Marreiros, N. A, et al. Conhecimento botânico tradicional sobre plantas medicinais no Semiárido da Paraíba (Nordeste, Brasil) Revista Ouricuri,5(1), 110-144, 2015.Disponível em: https://revistas.uneb.br/index.php/ouricuri/article/view/1271

[27] MMA - Ministério do Meio Ambiente. Gestão Florestal para a Produção Sustentável de Bens e Serviços no Brasil. Brasília: Serviço Florestal Brasileiro, 2010.

[28] Padoch, C.; De Jong, W.. Diversity, variation, and change in Ribereno agriculture. En: Kent H. Redford y Christine Padoch, (eds) Conservation of Neotropical Forests Working from Traditional Resource Use editors. New York: Columbia University Press, p.158-174, 1992.

[29] Pareyn, F.G.C. Os recursos florestais nativos e a sua gestão no estado de Pernambuco - o papel do manejo florestal sustentável. In: BRASIL, Ministério do Meio Ambiente. Gestão Florestal para a Produção Sustentável de Bens e Serviços no Brasil. Brasília: Serviço Florestal Brasileiro, p 99-115, [2010?].

[30] Pedrosa, M. K., et al. Uso e disponibilidade local de Sideroxylon obtusifolium (Roem \& Schult.) T. D. Penn. (Quixabeira (Sideroxylon obtusifolium (Roem. \& Schult.) T.D. Penn.) ) em três regiões da depressão sertaneja da Paraíba, Nordeste do Brasil. BIOFAR, 158-183, 2012.Disponível em: http://sites.uepb.edu.br/biofar/download/vespecial-2012/USO\%20E\%20DISPONIBILIDADE\%20LOCAL\%20DE\%20Sideroxylon\%20obtusifolium\%2017-082012.pdf 
[31] Pereira, B. E.; Diegues, A. C. Conhecimento de populações tradicionais como possibilidade de conservação da natureza: uma reflexão sobre a perspectiva da etnoconservação. Desenvolvimento e Meio Ambiente, 22, 37-50, 2010.Disponível em: http://revistas.ufpr.br/made/article/view/16054

[32] Peroni, N.; Begossi, A. ; Hanazaki, N. . Artisanal fishers ethnobotany: from plant diversity use to agrobiodiversity management. Environment, Development and Sustainability, 10, 623-637, 2008. Disponível em: https://link.springer.com/article/10.1007/s10668-008-9151-6

[33] Posey, D. A. Indigenous ecological knowledge and development of the Amazon. In: Moran, E.F. (ed). The dilemma of Amazonian development. Boulder: Westview, p. 225- 257. 1983.

[34] Roque, A.A.; Rocha, R.M. ; Loiola, M.I.B. Uso e diversidade de plantas medicinais da Caatinga na comunidade rural de Laginhas, município de Caicó, Rio Grande do Norte (nordeste do Brasil) Rev. Bras. Pl. Med., 12(1), 31-42, 2010. Disponível em: http://www.scielo.br/pdf/rbpm/v12n1/v12n1a06

[35] Rossato, S.C.; Leitão-Filho, H.F.; Begossi, A. "Ethnobotany of Caiçaras of the Atlantic Forest Coast (Brazil)". Economic Botany, 53, 387-395, 1999. Disponível em: https://link.springer.com/article/10.1007\%2FBF02866716?LI=true

[36] Santoro, F. R. et al Does plant species richness guarantee the resilience of local medical systems? A perspective from utilitarian redundancy. Plos One [1932-6203] $102015 . \quad$ Disponível em: http://journals.plos.org/plosone/article?id=10.1371/journal.pone.0119826

[37] Silva, J. P. F. Manejo Florestal Sustentável da Caatinga: Adequação Ambiental e Produção de Energia Agroecológica em Projetos de Assentamento e Propriedades Coletivas do Plano Nacional de Reforma Agrária. Rev. Bras. De Agroecologia, 4(2), $977 \quad-\quad 980,2009 . \quad$ Disponível em: http://www.agroecologiaemrede.org.br/upload/arquivos/frm_exp_geral_ex_anexos_0_821_RBA-2009-2724.pdf

[38] Silva, M.A.M. et al Fatores socioambientais influenciados pela seca na conservação da caatinga. HOLOS, 32(4), 245-257, 2016.Disponível em: http://www2.ifrn.edu.br/ojs/index.php/HOLOS/article/view/4175

[39] Silva, S.L.C. et al. plantas medicinais usadas pela comunidade do Povoado de Laços (Tanhaçú/Bahia) e encontradas na Floresta Nacional Contendas do Sincorá. Revista Caatinga. 25(3), 130-136, 2012. Disponível em: https://periodicos.ufersa.edu.br/index.php/caatinga/article/view/2180

[40] Sousa, R.F. et al. Estudo Etnobotânico de Myracrodruon urundeuva Allemão no Vale do Piancó (Paraíba, Nordeste, Brasil) BIOFAR, 7(1), 72-83, 2012.Disponível em: http://sites.uepb.edu.br/biofar/download/v7n12012/estudo_etnobotanico_de_myracrodruon_urundeuva_allemao_no_vale_do_pianco.pdf

[41] Vedruscolo, J. et al. Phytosociological survey of arboreous species in conserved and desertified areas in the semi-arid region of Paraíba, Brazil. Afr. J. Agric. Res, 12(10), . 805-814, 2017. Disponível em: http://www.academicjournals.org/journal/AJAR/article-abstract/24D2C5A63080

[42] Verdejo, M. E. Diagnóstico rural participativo: guia prático DRP. Brasília: Ministério de Desenvolvimento Agrário. Secretaria da Agricultura Familiar, 2006.

[43] Zuchiwschi, E. Florestas Nativas na Agricultura Familiar de Anchieta, Oeste de Santa Catarina: Conhecimentos, Usos e Importância. Florianópolis, Dissertação (Mestrado em Ciências com Área de Concentração em Recursos Genéticos Vegetais.) - UFSC, 2008. 


\section{Capítulo 18}

Aperfeiçoando o procedimento padrão para a análise de demanda bíoquímica de oxigênio ( $d b o$ ) da água no estado da Paraíba.

Nelson Medeiros de Assis Júnior

Eduardo Augusto da Silva Diniz.

Marcelo da Silva Pedro

Resumo: 0 presente trabalho trata-se do fruto de um estágio supervisionado exigido pelo

departamento de Engenharia Química - DEQ, da Universidade Federal da Paraíba UFPB, como pré-requisito para obtenção do título de bacharel em Engenharia Química. 0 mesmo, foi realizado no Laboratório de Medições Ambientais da Superintendência de Desenvolvimento do Meio Ambiente - SUDEMA, uma empresa pública do seguimento de serviços, responsável pela normalização e monitoramento das águas do estado da Paraíba. Sobre as principais competências do estágio, é possível destacar o respaldo na aprovação de laudos de processos, elaboração de relatórios, acompanhamento da rotina de trabalho de coletas, com cronogramas de entrega, metas objetivadas e prazos definidos; manutenção e produção de soluções químicas para uso e estoque, e testes laboratoriais para certificação da qualidade de amostras de águas expostas a contaminantes sanitários. Das técnicas realizadas para a quantificação dos agentes poluentes das águas, para fim de estudo desse relatório, foi destacado o método de obtenção da Demanda Bioquímica de Oxigênio - DBO, pelo o método de Winkler, método esse que foi possível observar ser bastante instável, não só por ser um processo bioxidativo, como também por estar sujeito a uma maior margem de erros e retrabalhos, devido só ser possível obter seus resultados em 5 dias corridos. Contudo, foi desenvolvido fluxogramas de processos e implementação e uso da ferramenta da qualidade que trata a análise dos modos de falha e seus efeitos (FMEA), como meio qualitativo de coleta de indicadores de qualidade. Propondo, assim, medidas de melhora do processo e estendendo para o ambiente trabalho, alertando sobre a importância do uso da gestão da qualidade e das boas práticas de laboratório para a melhoria de resultados.

Palavras-chave: Estágio supervisionado, FMEA, Gestão da qualidade, DBO. 


\section{INTRODUÇÃO}

A análise de águas é um procedimento importante para determinar as classificações para consumo humano das diversas fontes hídricas existentes, assim como atestar a qualidade de tratamentos aplicados para o reaproveitamento da água (CONAMA, 2008). Diversas empresas atuam na fiscalização e normalização ambiental através da detecção de indicadores de poluentes ecológicos, para desenvolver ações de vigilância e controle da qualidade da água, realizando o monitoramento de mananciais de captação e da potabilidade da água para consumo humano, bem como procedimentos em situações de emergência (FUNASA, 2004).

A água contém, geralmente, diversos componentes, os quais provêm do próprio ambiente natural ou foram introduzidos a partir de atividades humanas. Para caracterizar uma água, são determinados diversos parâmetros, os quais representam as suas características físicas, químicas e biológicas. Esses parâmetros são indicadores da qualidade da água e constituem impurezas quando alcançam valores superiores aos estabelecidos para determinado uso. No Brasil, os padrões de qualidade da água, segundo as diferentes classes, são estabelecidos pelo CONAMA (Conselho Nacional do Meio Ambiente) na Portaria no 518, de 25 de março de 2004, que fixa os procedimentos e responsabilidades relativas ao controle e vigilância da qualidade da água para consumo humano e seu padrão de potabilidade. E a resolução no 357, de 17 de março de 2005 e no 357/2005 e Resolução Conama no 396/2008, estabelece as condições e os padrões de lançamento de efluentes líquidos. (VEIGA, 2005)

A medida da DBO, um parâmetro importante para detectar a presença de matéria orgânica na água (FUNASA, 2014), mostra alguns desafios operacionais. É proposto a aplicação da ferramenta da qualidade denominada Análise do Modo e Efeito de Falha ou simplesmente FMEA (do inglês Failure Mode and Effect Analysis) para melhorar o procedimento padrão de medida da DBO feita pela Superintendência de Administração do Meio Ambiente - Paraíba (SUDEMA PB), que realiza análises de água provenientes de todo o estado. O FMEA é uma técnica utilizada como maneira de garantir que fontes de falha tenham sido localizadas (CARVALHO, 2013).

De forma geral, objetivou-se definir indicadores para orientar um processo de otimização do procedimento de análise da DBO, conseguindo-se uma melhor prestação de serviço à população por parte da SUDEMA. Especificamente, buscou-se compreender os riscos de trabalho envolvidos em laboratório químico, propondo alternativas que facilitem e/ou promovam melhor visibilidade e normalização sobre Boas Práticas de Laboratório (BPL) e biossegurança; prospectar possíveis falhas de precisão nas análises, propor melhorias para sua realização e monitoramento e propor um procedimento operacional padrão melhorado para a análise.

\section{METODOLOGIA}

A matéria orgânica de água é necessária aos seres heterótrofos, na sua nutrição, e aos autótrofos, como fonte de sais nutrientes e gás carbônico. Em grandes quantidades, no entanto, podem causar alguns problemas, como cor, odor, turbidez e consumo do oxigênio dissolvido pelos organismos decompositores. O consumo de oxigênio é um dos problemas mais sérios do aumento do teor de matéria orgânica, pois provoca desequilíbrios ecológicos, podendo causar a extinção dos organismos aeróbicos. Geralmente, são utilizados dois indicadores do teor de matéria orgânica na água: Demanda Bioquímica de Oxigênio (DBO) e Demanda Química de Oxigênio (DQO) (FUNASA, 2014).

A Demanda Bioquímica de Oxigênio foi determinada pelo o seu cálculo indireto, onde se calculou a diferença de Oxigênio Dissolvido (OD) através do método de Winkler modificado pela azida sódica ou Teste DBO 5-Dia, que consiste na análise das amostras de água em vidros de DBO (FUNASA, 2014). Os OD’s calculados foram preenchidos manualmente em formulários, uma vez no momento da incubação e uma segunda vez no quinto dia de incubação onde se realizava as medidas da DBO. A aplicação do FMEA de processos realiza a análise de falhas a fim de detectar riscos do processo de obtenção das DBO's e prevenir falhas em sua execução. Relacionando gravidade do efeito (G), ocorrência da causa $(0)$ e capacidade de detecção (D) para expressar o quanto o procedimento está desviando de sua conformidade, tornando possível uma releitura da realização do procedimento e geração de ações preventivas para reduzir ou eliminar as fontes de erros (MACHADO, 2012). 


\section{RESULTADOS E DISCUSSÃO}

A aplicação do FMEA de processos realiza a análise de modos e falhas, afim de detectar riscos do processo de obtenção das DBO's e prevenir falhas em sua execução. Relacionando gravidade do efeito (G), ocorrência da causa (0) e capacidade de detecção (D) para expressar o quanto o procedimento está desviando de sua conformidade. Tornando possível uma releitura da realização do procedimento e geração de ações preventivas para reduzir ou eliminar as fontes de erros.

A princípio definiu-se o processo, sua não conformidade, as causas básicas das falhas e seus meios de detecção, de acordo com a Figura 1. Em seguida definiu-se escalas para cada variável, projetou o painel do FMEA com as situações descritas para cada elemento e obteve o índice de riscos para situação. Por fim, priorizou cada falha e esclareceu ações de prevenção para melhoria do processo.

Figura 1 - Sintetização do processo em análise do FMEA do processo.

\begin{tabular}{|c|c|c|c|}
\hline & Efeito da Falha & Causa Básica da Falha & Meio de Detecção \\
\hline \multirow{4}{*}{$\begin{array}{l}\text { Análise de } \\
\text { DBO }\end{array}$} & $\begin{array}{l}\text { Resultados fora } \\
\text { dos Parâmetros. }\end{array}$ & $\begin{array}{l}\text { Contaminação por Sucção da } \\
\text { Solução. }\end{array}$ & $\begin{array}{c}\text { Presença de maior } \\
\text { demanda de matéria de } \\
\text { OD após a incubação. }\end{array}$ \\
\hline & & $\begin{array}{l}\text { Água de Diluição irregular. } \\
\text { Vidrarias contaminadas }\end{array}$ & $\begin{array}{c}\text { Revisão da assepsia das } \\
\text { Vidrarias. }\end{array}$ \\
\hline & & Coleta Indevida da Amostra. & $\begin{array}{l}\text { Verificar as condições } \\
\text { dos pontos de coleta. }\end{array}$ \\
\hline & & Falha no periodo de incubação. & $\begin{array}{l}\text { Verificação da } \\
\text { Temperatura Adequada } \\
\text { e do periodo de } 5 \text { dias. }\end{array}$ \\
\hline
\end{tabular}

Para hierarquizar os itens analisados pelo FMEA, utilizou-se uma escala de 1 a 5 partindo da menor para a maior significância de ocorrência e gravidade, mostrado na Tabela 1. Onde para a ocorrência estabelece valores apontando a probabilidade de a falha ocorrer, e para a gravidade o quanto severo é o efeito da causa para gerar a falha.

Tabela 1 - Relação de escala: peso para a ocorrência de causa (0) e gravidade do efeito (G).

\begin{tabular}{|c|c|c|c|c|}
\hline Remota & Baixa & Moderada & Alta & $\begin{array}{l}\text { Muito } \\
\text { Alta }\end{array}$ \\
\hline 1 & 2 & 3 & 4 & 5 \\
\hline
\end{tabular}

De modo semelhante enumerou para a capacidade de deteç̧ão (Tabela 2), onde "muito alta" significa que o operador durante a operação quase que certamente será possível verificar e detectar a falha do processo e "remota", implica que o programa de verificação não detectara a falha.

Tabela 2 - Relação de escala: Peso para a probabilidade de detecção da falha do processo

\begin{tabular}{|c|c|c|c|c|} 
Remota & Baixa & \multicolumn{1}{c}{ Moderada } & Alta & $\begin{array}{c}\text { Muito } \\
\text { Alta }\end{array}$ \\
\hline 5 & 4 & 3 & 2 & 1 \\
\hline
\end{tabular}

Abaixo é projetado e preenchido o painel do FMEA de processo para análise das DBO's, o índice de risco foi calculado pelo produto das três variáveis em questão, como mostra a Figura 2. 0 formulário estabelece ainda dados sobre o responsável pela sua execução, sua data de execução e fornece uma visão clara e objetiva da relação de falha e efeitos. 
Figura 2 - Formulário preenchido do FMEA do processo de obtenção das DBO's.

\begin{tabular}{|c|c|c|c|c|c|c|c|}
\hline \multicolumn{2}{|c|}{ FMEA de Processo } & \multicolumn{3}{|c|}{ ELABORADO POR: } & \multicolumn{3}{|l|}{ DATA:: $I_{1}$} \\
\hline \multirow{2}{*}{ PROCESSO } & \multicolumn{4}{|c|}{ POSSIVEIS FALHAS } & \multirow{2}{*}{$\begin{array}{l}\text { MEIO DE } \\
\text { DETECÇÄO }\end{array}$} & \multirow{2}{*}{ DETECÇÃO } & \multirow{2}{*}{$\begin{array}{l}\text { INDICE } \\
\text { DE } \\
\text { RISCO } \\
(\mathrm{GxO} \times \mathbf{0})\end{array}$} \\
\hline & $\begin{array}{l}\text { EFEITODA } \\
\text { FALHA } \\
\end{array}$ & GRAVIDADE & $\begin{array}{l}\text { CAUSA BASICA DA } \\
\text { FALHA } \\
\end{array}$ & OCORRÉNCIA & & & \\
\hline & $\begin{array}{l}\text { Resultados } \\
\text { fora dos } \\
\text { Parâmetros. }\end{array}$ & 5 & Pipetagem via oral & 4 & $\begin{array}{l}\text { Presença de maior } \\
\text { demanda de } \\
\text { matéria } O D \text { após a } \\
\text { incubação. }\end{array}$ & 3 & 60 \\
\hline & & 4 & $\begin{array}{l}\text { Água de Diluição } \\
\text { irregular. }\end{array}$ & 4 & \multirow{2}{*}{$\begin{array}{l}\text { Revisão da } \\
\text { assepsia das } \\
\text { Vidrarias. }\end{array}$} & 4 & 64 \\
\hline & & 4 & $\begin{array}{c}\text { Mal Esterilização } \\
\text { o das Vidrarias }\end{array}$ & 3 & & 4 & 48 \\
\hline & & 3 & $\begin{array}{c}\text { Coleta Indevida da } \\
\text { Amostra. }\end{array}$ & 2 & $\begin{array}{l}\text { Verificar as } \\
\text { condições de } \\
\text { coleta e seus } \\
\text { pontos. }\end{array}$ & 4 & 24 \\
\hline & & 5 & $\begin{array}{l}\text { Falha no período } \\
\text { de incubação. }\end{array}$ & 2 & $\begin{array}{c}\text { Acompanhamento } \\
\text { da } \mathrm{T}\left({ }^{\circ} \mathrm{C}\right) \text { e tempo } \\
\text { de incubação. }\end{array}$ & 2 & 20 \\
\hline
\end{tabular}

Quanto mais elevado o índice de risco (GxOxD) sobre a causa, maior a urgência de adotar ações corretivas, conforme a Figura 3. Através de uma análise gráfica dos índices é possível obter uma visão global sobre as necessidades de melhora do processo e em seguida propor ações preventivas.

Figura 3 - Variação dos índices de gravidade (a), ocorrência (d), detecção (b) e variação do índice de risco
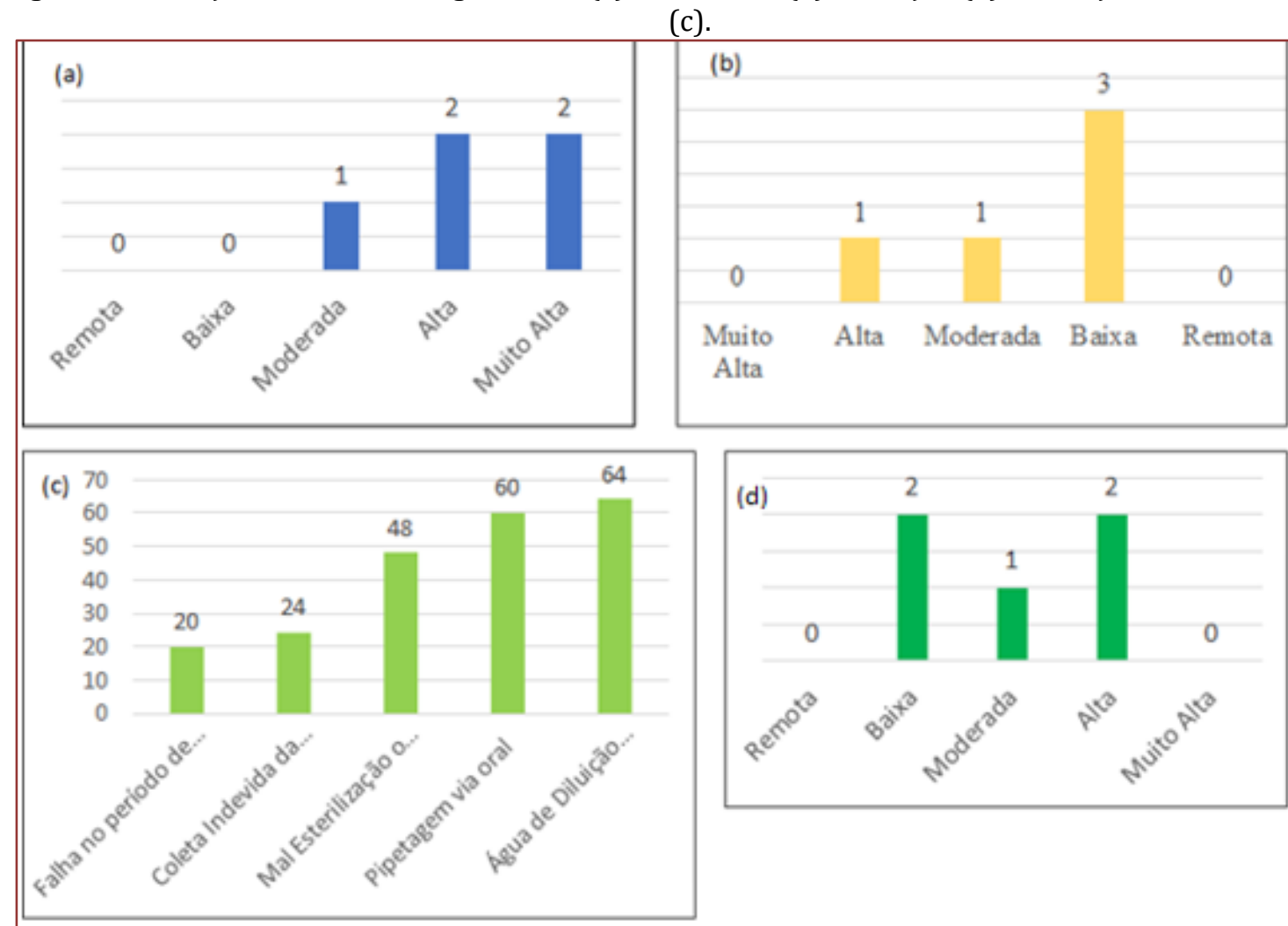
Os gráficos acima evidenciam que o processo ocorre com um nível de gravidade oscilando entre moderado e muito alto, ocorrências de falhas do processo instável entre baixa e alta, e contrastando com um nível de detecção em quase sua totalidade sendo baixo.

Com os dados obtidos do formulário do FMEA e a sua análise gráfica é possível sugerir algumas medidas de prevenção afim de otimizar o processo. Assim é descrito na Tabela 3 um quadro com possíveis soluções, setor responsável e tempo de execução.

Tabela 3 - Medidas de prevenção para otimização do processo.

\begin{tabular}{|c|c|c|}
\hline Medidas & Prazo & Responsável \\
\hline Elaboração de Mapas de Risco & 1 mês & Técnicos e coordenação do laboratório \\
\hline $\begin{array}{c}\text { Treinamento sobre biossegurança e } \\
\text { BTL }\end{array}$ & 1 mês & Coordenação e departamento pessoal \\
\hline Revisão das metodologias de análise & 1 mês & Técnicos e coordenação do laboratório \\
\hline $\begin{array}{l}\text { Introduzir o teste de glutamina para } \\
\text { o teste de diluição }\end{array}$ & 1 mês & Técnicos e coordenação do laboratório \\
\hline
\end{tabular}

O processo ocorre com um nível de gravidade oscilando entre moderado e muito alto, ocorrências de falhas do processo instável entre baixa e alta, e contrastando com um nível de detecção em quase sua totalidade sendo baixo. A classificação apontou para os principais riscos do processo de obtenção de DBO's pelo o modelo clássico de incubação. Com base na análise do formulário de FMEA e verificação pela análise empírica, é possível evidenciar os principais fatores responsáveis pela ineficiência do procedimento, que como consequência gerava o retrabalho da operação. A partir da quantificação e classificação, as medidas de ação foram sugeridas conforme o peso do índice de risco.

\section{CONCLUSÕES}

Os trabalhos resultaram numa tabela de índice de risco (GxOxD). Quanto mais elevado o índice de risco de uma causa, maior a urgência de adotar ações corretivas. Através de uma análise gráfica dos índices foi possível obter uma visão global sobre as necessidades de melhora do processo e em seguida propor ações preventivas. De acordo com essa análise, a água de diluição irregular (índice de risco 64) e a pipetagem via oral (índice de risco 60), ambos presentes nos procedimentos que o método de Winkler, são as causas principais que resultam numa análise errônea, que deverá ser descartada. De acordo com a análise completa do FMEA, foi proposto como ações de melhoria a elaboração de mapas de risco, o treinamento sobre biossegurança, a revisão das metodologias de análise e a proposição do teste de glutamina para a água de diluição. Foi proposto também uma versão atualizada de procedimento operacional padrão (RICE et al., 2012). Este trabalho permitiu, de forma clara e direta, determinar ações corretivas no processo de medida da DBO. Através do índice de riscos foi possível escalar a hierarquia de atuação pelo o uso de medidas corretivas para as causas de falhas, propondo melhorias. Foi possível destacar a importância das boas práticas de laboratório como cruciais para organização, higienização e bem-estar das pessoas. 0 uso da gestão da qualidade serviu como ferramenta para promover uma visão geral do processo e fornecer indicadores para o otimizar. 0 passo seguinte consiste em introduzir as melhorias e realizar o acompanhamento das novas práticas.

Palavras-chave: Demanda Bioquímica de Oxigênio, FMEA, análise de água.

\section{REFERÊNCIAS}

[1] Aureliano, Joana Teresa. "Balneabilidade das praias de Pernambuco o núcleo metropolitano." Recife: UFPE. Dissertação de Mestrado Apresentada ao Programa de Pós-Graduação em Gestão e Políticas Ambientais (2000).

[2] Brasil. Ministério da Saúde. Fundação Nacional de Saúde. Manual de controle da qualidade da água para técnicos que trabalham em ETAS / Ministério da Saúde, Fundação Nacional de Saúde. - Brasília: Funasa, 2014.

[3] Carvalho, Marly, and Edson Paladini. Gestão da qualidade: teoria e casos. Elsevier Brasil, 2013.

[4] Crosby, Philip B. Qualidade é Investimento. Rio de Janeiro: José olympio: 1986. 
[5] Dezotti, Márcia. Processos e técnicas para o controle ambiental de afluentes líquidos. Rio de Janeiro: Papers, 2008. CUTOLO, Silvana Audrá. http://portalpnqa.ana.gov.br/indicadores-indice-aguas.aspx acessado em 20 ago. 2017. (Acessado em Março de 2017).

[6] Junior, E. J. C., Implantação do FMEA em laboratório para a melhoria dos processos de pesquisa: um estudo de caso. In: XV Seprosul Simposio DE Ingenieria DE LA Produccion Sudamericano, 2015, Sorocaba/SP - Brasil. Trabalho apresentado. São Paulo: Conference Paper, 2015. p.1-4.

[7] NR, Norma Regulamentadora Ministério do Trabalho e Emprego. NR-9 - Programa de Prevenção de Riscos Ambientais. 2009. http://www.aguahesp.com.br/agua2.htm, acessado em 20 ago. 2017.

[8] Rodrigues, Marcus Vinicius. Ações para a qualidade: GEIQ, gestão integrada para a qualidade: padrão seis sigmas, classe mundial. Rio de Janeiro: Qualitymark, 2004.

[9] Resolução Conama, no 396, de 3 de abril de 2008 Publicada no DOU no 66, de 7 de abril de 2008, Seção 1, páginas 64-68.

[10] Machado, S. S., - Gestão da qualidade / - Inhumas: IFG; Santa Maria: Universidade Federal de Santa Maria, 2012.

[11] Rice, E.W., Baird, R.B., Eaton, A.D. And Clesceri, L.S. (Eds.) Standard Methods for the Examination of Water and Wastewater. 22nd Edition, American Public Health Association, American Water Works, Water Environment Federation, Washington DC, 2012.

[12] Zambom, Rafael Appoloni; Barca, Luiz Fernando (Comp.). Projeto do laboratório de análises físico-químicas de petróleo da unifei: levando em consideração as boas práticas laboratoriais. Revista P\&d em Engenharia de Produção, Minas Gerais, p.01-12, 29 nov. 2008. Semanal. 


\section{Capítulo 19}

\section{Análise estatística para identificação de tendências no regime de chuvas para o agreste meridional do estado de Pernambuco}

\section{Antônio Ricardo Santos de Andrade}

Anízio Honorato Godoi Neto

Adiel Felipe da Silva Cruz.

Erivaldo Laurentino da Silva

Anderson Santos da Silva

Resumo: Variações da temperatura do ar e precipitação pluviométrica, inundações, desestabilização de encostas, secas, dentre outras, podem causar impactos econômicos e sociais. A seca, é caracterizada pela ausência de precipitação durante longos períodos. Trazendo consequências severas à região Nordeste, em especial à semiárida. A variabilidade espaço-temporal de precipitações pluviométricas vem a ser uma marcante característica no clima da Região Nordeste do Brasil (NEB), sobre a porção semiárida de modo particular, onde constitui um fator de grande importância. Desta forma, este trabalho buscou realizar uma a análise estatística para identificar anos-padrão secos, chuvosos e tendência da precipitação pluviométrica anual ou mudança do comportamento da mesma para o Agreste Meridional do Estado de Pernambuco. Foi avaliada uma série histórica de dados de 30 anos da precipitação pluviométrica total anual. A área de estudo corresponde à região formada pela união de 71 municípios distribuídos em seis mesorregiões e está inserida na área de abrangência denominada de "Polígono das Secas", mas apresentando, um período de estiagem menor que a do sertão, devido a sua proximidade ao litoral. Para a realização deste trabalho foram utilizados dados anuais de precipitação pluvial, obtidos junto a Agência Pernambucana de Águas e Clima (APAC) e Agência Nacional de Águas (ANA). O período escolhido foi de janeiro de 1985 a 12 de julho de 2014 totalizando 30 anos. Os trinta anos apresentam características excepcionais no que tange a volume de chuva precipitado e/ou sua distribuição ao longo do ano, principalmente quando se toma como parâmetro o regime anual das chuvas De modo geral observa-se uma tendência negativa (diminuição da precipitação) bastante expressiva e significativa sobre grande parte as mesorregiões (dos municípios).

Palavras-Chave: Variabilidade; tendência; precipitação; região nordeste. 


\section{INTRODUÇÃO}

Variações da temperatura do ar e precipitação pluviométrica, inundações, desestabilização de encostas, secas e necessidade crescente de conhecimento do comportamento da água para o planejamento e desenvolvimento das atividades agropecuárias e não agropecuárias, podem causar impactos econômicos e sociais. Sendo este problema recorrente, uma vez que variáveis climatológicas apresentam flutuações significativas ao longo do tempo, havendo anos mais secos, em alguns anos, rigorosos períodos de chuva (Silva, 2013).

0 Estado de Pernambuco possui histórico de desastres naturais muitas vezes ligados a estiagens e à seca. As estiagens se caracterizam pela menor intensidade e por sua ocorrência ser em menores períodos de tempo. A seca, por sua vez, é caracterizada pela ausência de precipitação durante longos períodos. Trazendo consequências severas à região Nordeste, em especial à semiárida. Muitos municípios pernambucanos, biota local e milhares de famílias são afetadas pela seca, ocasionando um grave desabastecimento urbano. A geração de energia elétrica também é afetada, através da redução da vazão de rios afetados pela seca, uma vez que resultam de uma complexa interação dos diversos processos de armazenamento e transporte da água no ciclo hidrológico, a depender da capacidade de infiltração do solo e da chuva (Ramos, 2010).

No caso do Agreste Meridional do Estado de Pernambuco, devido ao seu processo de produção territorial/espacial, a importância de se verificar o regime pluviométrico, ganha relevância devido à tropicalidade presente neste espaço. Espacializar e discutir o comportamento temporal dos fenômenos atmosféricos, nesse caso as chuvas, e suas correlações com o meio terrestre, dão condições para a obtenção de respostas quanto aos efeitos do regime pluvial, como eles se manifestam no espaço, no cotidiano da sociedade. Isso significa abranger a relação existente entre a dinâmica do clima e a produção espacial presentes no território (Schneider \& Silva, 2014).

A escolha de anos-padrão secos, chuvosos representa uma etapa importante na pesquisa climatológica, pois a partir dela, se avaliará a variação ou oscilação climática a partir da altura da chuva registrada e que repercutem no espaço geográfico do Agreste Meridional do Estado de Pernambuco. Segundo SCHNEIDER \& SILVA (2014) os anos considerados excepcionais ditos secos ou chuvosos devem corresponder aos períodos em que trouxeram impactos tanto sociais, quanto econômicos, tanto pela falta, quanto pelo excesso de chuva.

Conforme LACERDA et al. (2009), a variabilidade espaço-temporal de precipitações pluviométricas vem a ser uma marcante característica no clima da Região Nordeste do Brasil (NEB), sobre a porção semiárida de modo particular, onde constitui um fator de grande importância, é a irregularidade das chuvas. Recentemente, estudos sobre mudanças climáticas regionais têm mostrado uma mudança no padrão total anual de precipitação sobre o NEB. Em regiões como a semiárida do Nordeste brasileiro, a precipitação é uma variável determinante das condições do clima local, bem como sua variabilidade e mudança em longos períodos (Santos et al., 2009).

Neste contexto, este estudo tem como objetivo a análise estatística para identificar anos-padrão e tendência da precipitação pluviométrica anual ou mudança do comportamento da mesma para o Agreste Meridional do Estado de Pernambuco. Foi avaliada uma série histórica de dados de 30 anos da precipitação pluviométrica total anual e da média anual, cedidas pelo Instituto Agronômico de Pernambuco (IPA) e pela Superintendência do Desenvolvimento do Nordeste (SUDENE), correspondentes ao período de 1984 a 2014 da precipitação pluviométrica das várias estações meteorológicas espacialmente localizadas em seis mesorregiões do Agreste Pernambucano, formada pela união de 71 municípios.

\section{MATERIAL E MÉTODOS}

A área de estudo corresponde à região formada pela união de 71 municípios distribuídos em seis mesorregiões e está inserida na área de abrangência denominada de "Polígono das Secas", mas apresentando, um período de estiagem menor que a do sertão, devido a sua proximidade ao litoral. Para a realização deste trabalho foram utilizados dados anuais de precipitação pluvial, obtidos junto a Agência Pernambucana de Águas e Clima (APAC) e Agência Nacional de Águas (ANA). 0 período escolhido foi de janeiro de 1985 a 12 de julho de 2014 totalizando 30 anos, para os 71 municípios das seis mesorregiões do Agreste Pernambucano na região Nordeste no Brasil. 
No intuito de identificar tendências significativas de precipitação pluviométrica e, ao mesmo tempo, verificar o comportamento e evolução da variabilidade espacial hidro climática da região em estudo, foram usados o teste paramétrico por meio do método de regressão linear e o teste " $\mathrm{t}$ - Student" para testar a significância dos coeficientes de regressão da reta ajusta a série de dados de precipitação (Theil, 2000; Félix et al., 2010). Desta forma, foi possível inferir se ocorrem, e quando, tendência numa determinada série histórica para a amostra estudada. 0 teste utilizado consiste em determinar o intervalo de confiança (IC) do coeficiente angular "a" da reta ajustada, ao nível de 1 e $5 \%$ de probabilidade, sendo que se este intervalo não incluir o valor zero, a tendência é significativa. Também pode verificar alterações climáticas pelo sinal do coeficiente angular da reta, assim, a $>0$ significa uma tendência crescente e a $<0$ indica uma tendência decrescente. Aplicou-se a metodologia Box Plot na identificação de anos-padrão, a partir do método utilizado por GALVANI \& LUCHIARI (2004) em estudos voltados para a identificação de anospadrão. A técnica propõe por meio de dados mensais, realizar uma análise temporal estatística a partir de dados pluviométricos mensais da série.

A técnica de quartis aliado a um gráfico Box Plot foi gerado pelo software R para a produção dos referidos resultados, trabalhando com valores máximos, medianas, 1ำ $2^{\circ}$ e $3^{\circ}$ quartis e valores mínimos. Este conjunto de medidas oferece a idéia da posição de dispersão, assimetria, caudas e dados discrepantes. Para a aplicação da técnica do Box Plot os valores máximo, mínimo e mediano da série de dados, foram introduzidos os quartis. Os quartis são divididos em três conjuntos contendo cada um $25 \%$ dos dados da série. 0 primeiro quartil ( $1^{\circ}$ Q) estará situado entre o (Vmín) e a mediana indicando meses secos. 0 segundo quartil ( $\left.2^{\circ} \mathrm{Q}\right)$ pode ser chamado de mediana, ou seja, que define a posição central da série. Já o terceiro quartil $\left(3^{\circ} \mathrm{Q}\right)$, está situado entre o mediano e o (Vmáx) indicando meses chuvosos.

Os Outliers são valores distantes que compõem a séria e serão denominados por valores extremos (Meses super-secos ou super-úmidos) e, portanto ficam fora da margem, pois podem comprometer a análise dos dados. Os mesmos estão representados pelo símbolo (*). Os meses em que estiverem entre os $5 \%$ menores serão considerados super-secos. Já os meses que estiverem entre os $5 \%$ maiores serão ponderados como super-chuvosos. No demais, os valores que se encontrarem entre o (Vmín) e 1o quartil serão considerados secos. Entre o $1^{\circ}$ e $3^{\circ}$ quartil serão considerados anos normais. E aqueles que se encontrarem entre o $3^{\circ}$ quartil e (Vmáx), serão considerados anos chuvosos. A Tabela 1 apresenta a síntese de intervalos adotados:

Tabela 1. Intervalos adotados para a classificação do regime pluviométrico para o Agreste Meridional do Estado de Pernambuco

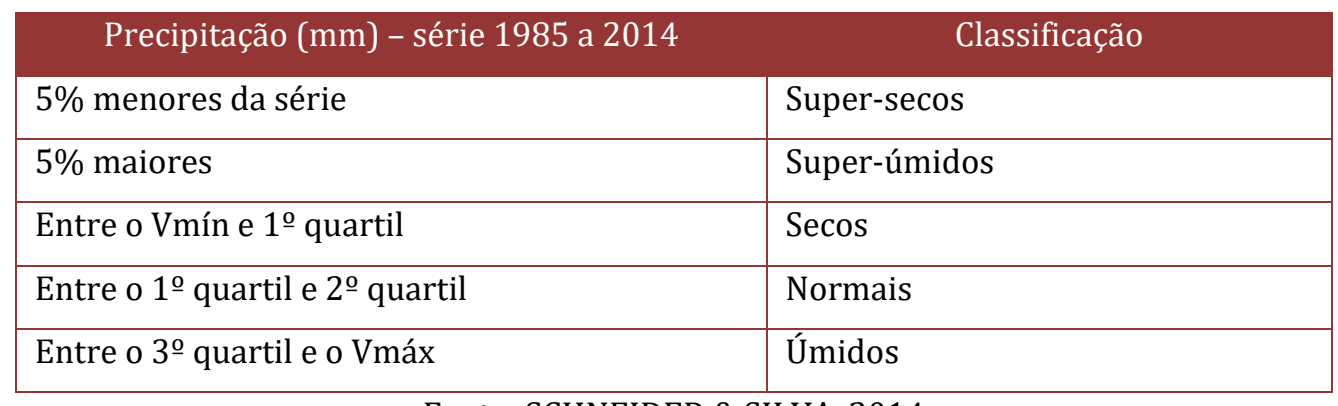

Fonte: SCHNEIDER \& SILVA, 2014

\section{RESULTADOS E DISCUSSÃO}

De acordo com o teste de Shapiro-Wilk para normalidade dos dados de precipitação média anual ao nível de $5 \%$ de significância verificou-se que os dados não seguem a distribuição normal, resultado este considerado comum a dados de pluviosidade.

Na Figura 1 é apresentado o mapa da distribuição espacial dos valores das precipitações pluviais totais para a série de 1985 a 12 de julho de 2014 para as seis mesorregiões (e seus 71 municípios) do Agreste Pernambucano. Verificou-se que as precipitações no sul (da microrregião do médio Capibaribe) e oeste (das mesorregiões vale do Ipanema e Ipojuca) variam de 15.000 a $20.000 \mathrm{~mm}$ (valor médio entre 500 a 666,66 mm), sudeste (da microrregião de Garanhuns) e leste (da microrregião do Brejo Pernambucano), variam de 15.000 a $22.000 \mathrm{~mm}$ (valor médio entre 500 a 733,33 mm). Já a área central da microrregião do 
Vale do Ipojuca apresenta precipitações totais anuais de 10.000 a 15.000 mm (valor médio entre 333,33 a $500 \mathrm{~mm}$ ).

Figura 1. Mapa da distribuição das isolinhas das precipitações pluviométricas totais anuais (mm/ano) das seis mesorregiões (e seus 71 municípios) do Agreste de Pernambucano, para a série de 1985 a 12 de julho de 2014 .

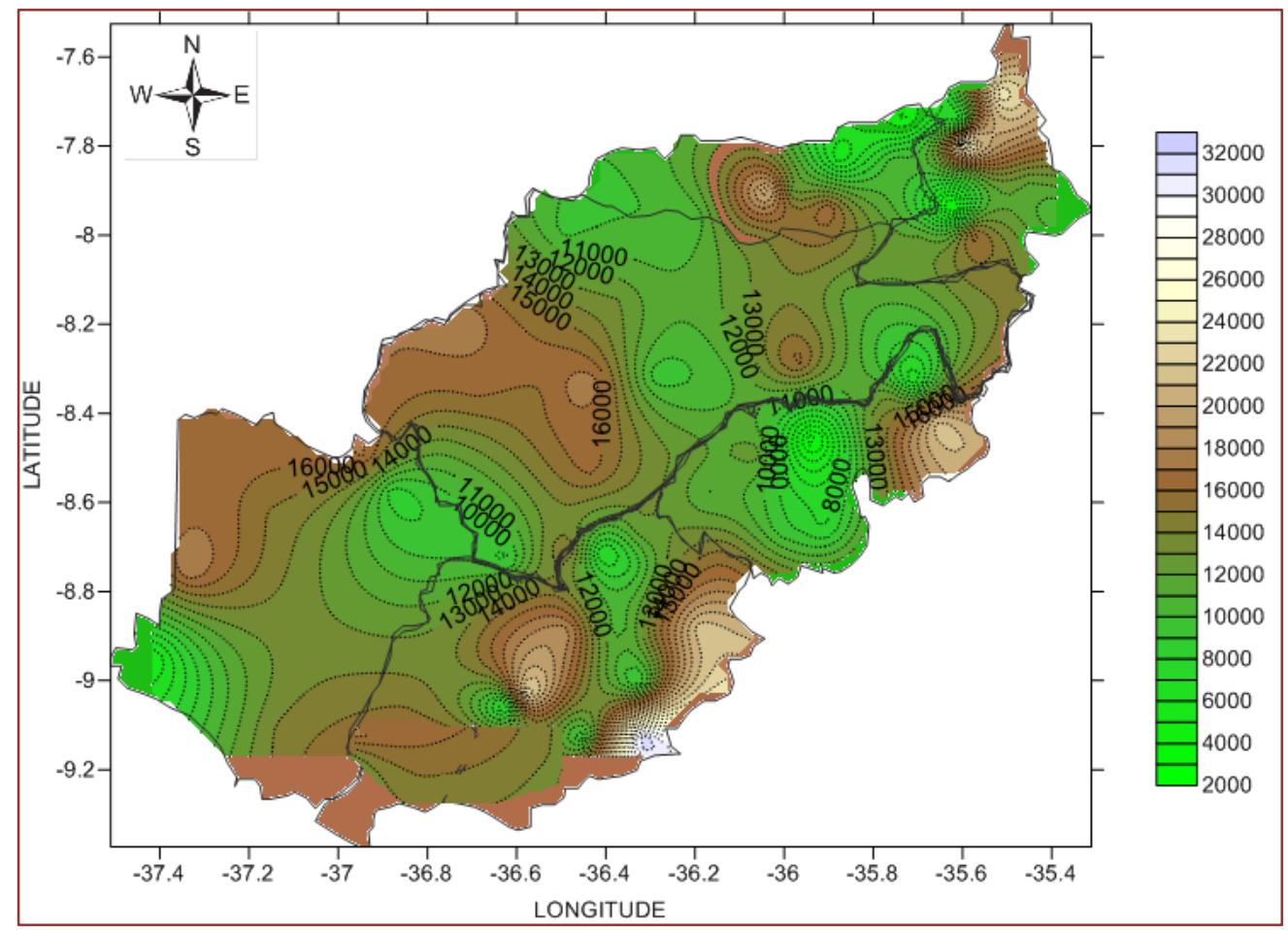

Ainda na Figura 1, observou que a série analisada apresenta anos com grande variabilidade pluviométrica, havendo períodos que se destacaram durante a série, devida á comportamentos díspares registrados. Mesmo que superficial, os dados apontam variabilidades durante os anos. Tais variabilidades serão tratadas a seguir aplicando-se o método de Box Plot. Segundo os pesquisadores: GALVANI E\&LUCHIARI (2004) e SCHNEIDER \& SILVA (2014), aplicaram a técnica de Box Plot na classificação de regimes pluviométricos em escala mensal. Técnica essa relativamente nova em estudos climatológicos nos permite entender os conceitos básicos para se trabalhar com análise de dados.

Os resultados da análise descritiva da precipitação mensal (Tabela 2). 0 ano de 2004 apresentou maior precipitação com 683,97 mm e 2012 com menor valor 155,75 mm. Os anos 1990, 1991, 1993, 1997, 1998, 1999, 2007, 2008, 2009, 2010, 2011, 2012 e 2013 apresentaram distribuição assimétrica positiva, com os valores médios maiores que a mediana, evidenciando alta variação da precipitação mensal na estação estudada. Os demais anos apresentam assimetria negativa. A curtose com distribuição leptocúrtica alongada - é evidenciada nos anos de 1990, 1991, 1992, 1993, 1998, 1999 e 2012 e platicúrtica - achatada - nos demais anos.

Os coeficientes de variação (CV) da precipitação mensal mostram que a variabilidade desse atributo é alta, segundo classificação proposta por WARRICK e NIELSEN (1980) citado por RAMOS et al. (2012), evidenciando a variabilidade da precipitação. Na estação chuvosa, o ano de 2004 apresentou CV (25,34\%), enquanto que na estação seca, o ano de 2012 CV (330,22\%). Segundo LIMA et al. (2008) e RAMOS et al. (2012) trabalhando com dados de Alegre/ES e Recife/PE, a ausência total de chuvas em alguns anos da série, nos meses de seca, também pode ser a explicação dessa variabilidade. 
Tabela 2. Parâmetros estatísticos da precipitação pluvial anual (mm), para a série de 1985 a 12 de julho de 2014 das seis mesorregiões do Agreste de Pernambucano.

\begin{tabular}{|c|c|c|c|c|c|c|c|c|}
\hline \multirow{2}{*}{ Anos } & \multicolumn{8}{|c|}{ Parâmetros estatísticos } \\
\hline & Vmín & Vmáx & Md & Med & DP & $\mathrm{CV}(\%)$ & $\mathrm{Ca}$ & $\mathrm{Ck}$ \\
\hline 2012 & 0,00 & 783,10 & 0 & 155.75 & 204,18 & 79,44 & 1,14 &, 50 \\
\hline 1998 & 0,00 & 828,00 & 175.55 & 196.98 & 182,31 & 101,47 & 1,09 & 1,17 \\
\hline 1993 & 0,00 & 891,10 & 209.4 & 216.20 & 182,53 & 95,62 & 0,83 & 1,29 \\
\hline 1990 & 0,00 & 1269,10 & 280.85 & 285.38 & 309,33 & 102,02 & 0,97 & 0,5 \\
\hline 1992 & 0,00 & 1434,60 & 0 & 286.43 & 410,64 & 96,68 & 1,26 & 0,52 \\
\hline 1991 & 0,00 & 2150,50 & 189.1 & 297.31 & 385,38 & 108,39 & 1,99 & 6,56 \\
\hline 1999 & 0,00 & 882,50 & 317.3 & 318.15 & 203,15 & 129,62 & 0,37 & 0,05 \\
\hline 1987 & 0,00 & 1241,90 & 380.6 & 327.62 & 313,25 & 143,37 & 0,57 & $-0,29$ \\
\hline 2008 & 0,00 & 1425,20 & 38.1 & 355.64 & 398,97 & 84,43 & 0,61 & $-0,87$ \\
\hline 2003 & 0,00 & 1140,00 & 3962.4 & 368.90 & 290,31 & 74,60 & 0,53 & $-0,07$ \\
\hline 1995 & 0,00 & 1170,10 & 378.5 & 377.47 & 296,98 & 78,68 & 0,23 & $-0,73$ \\
\hline 2014 & 0,00 & 1087,00 & 407.8 & 397.43 & 173,35 & 78,78 & ,55 & 2,92 \\
\hline 2006 & 0,00 & 1502,30 & 445.8 & 420.61 & 285,25 & 82,26 & 0,67 & 1,77 \\
\hline 1997 & 0,00 & 1322,10 & 401 & 426.71 & 351,03 & 92,55 & 0,33 & $-0,87$ \\
\hline 2009 & 0,00 & 1564,60 & 125.7 & 426.80 & 459,37 & 63,85 & 0,41 & $-1,30$ \\
\hline 2011 & 0,00 & 1744,20 & 189.6 & 430.89 & 492,69 & 64,04 & 0,74 & $-0,51$ \\
\hline 1996 & 0,00 & 1234,50 & 459.8 & 448.90 & 353,64 & 58,77 & 0,38 & $-0,570$ \\
\hline 2001 & 0,00 & 1042,00 & 505.6 & 469.15 & 275,72 & 54,41 & $-0,24$ & $-0,58$ \\
\hline 2007 & 0,00 & 1339,60 & 457.6 & 469.97 & 357,65 & 78,70 & 0,53 & $-0,24$ \\
\hline 2010 & 0,00 & 1498,90 & 356.1 & 470.21 & 508,57 & 62,37 & 0,38 & $-1,53$ \\
\hline 1988 & 0,00 & 2095,00 & 506.2 & 483.16 & 492,92 & 56,59 & 0,70 & $-0,00$ \\
\hline 1989 & 0,00 & 1793,85 & 583.7 & 519.61 & 502,37 & 67,82 & 0,50 & $-0,65$ \\
\hline 1986 & 0,00 & 2149,40 & 590 & 531.07 & 538,87 & 76,10 & ,78 & ,15 \\
\hline 1994 & 0,00 & 1593,30 & 649.6 & 569.72 & 425,00 & 112,18 & ,023 &,- 85 \\
\hline 2002 & 0,00 & 1440,40 & 643.8 & 612.59 & 333,29 & 107,63 &,- 33 &,- 04 \\
\hline 2013 & 0,00 & 1498,00 & 611.7 & 635.02 & 258,36 & 108,16 & 0,77 & 2,00 \\
\hline 1985 & 0,00 & 1767,50 & 823.5 & 647.41 & 514,32 & 114,34 & $-0,08$ & $-1,17$ \\
\hline 2005 & 0,00 & 1418,50 & 721.3 & 655.05 & 370,69 & 131,09 & $-0,09$ & $-0,46$ \\
\hline 2000 & 0,00 & 1653,00 & 720.4 & 681.11 & 436,18 & 40,69 & 0,031 & $-0,73$ \\
\hline 2004 & 0,00 & 1589,60 & 765.7 & 683.98 & 426,61 & 43,62 & $-0,26$ & $-0,61$ \\
\hline
\end{tabular}

Vmín = Valor mínimo; Vmáx = Valor máximo; $\mathrm{Md}=$ Mediana = Q2º quartil; Med = Média; DP = DesvioPadrão; Q1ํo = Primeiro quartil; Q3ํㅜ = Terceiro quartil; CV (\%) = Coeficiente de variação; Cs = Coeficiente de assimetria; $\mathrm{Ck}=$ Coeficiente de curtose 
Analisando os box-plots, percebeu-se que a longa cauda acima de todas as caixas indica que as distribuições das precipitações pluviométricas são assimétricas positivamente, com exceção dos anos 2011 e 2012 (Figura 2).

Figura 2. Box-plot da precipitação pluviométrica da precipitação pluvial anual (mm), para a série de 1985 a 12 de julho de 2014 das seis mesorregiões do Agreste de Pernambucano.

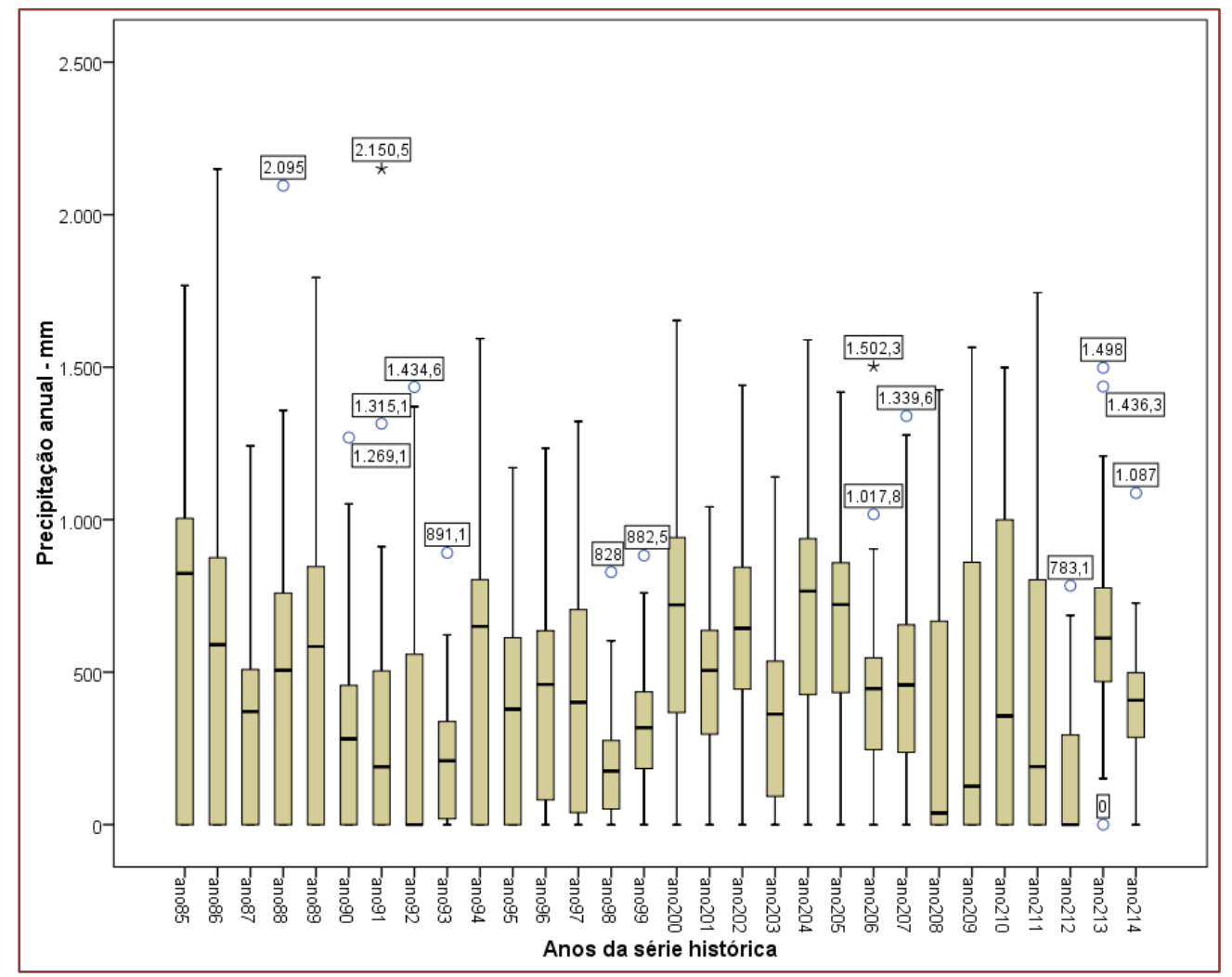

O outlier (asterisco) indica que existe uma observação atípica neste conjunto de dados constata segundo a aplicação do método, observou-se que dos 30 anos apenas dois são atípicos, sendo esses anos considerados chuvosos (1991 e 2006), havendo destaque para o ano de 2001 considerado um ano superchuvoso devido ao grande volume pluviométrico registrado (Figura 2). Os valores máximo e mínimos (representados por circunferências) no Box Plot, indica que existe uma observação de anos úmidos e secos, respectivamente, neste conjunto de dados, ressalva que dos 30 anos da série historia de dados estudos, foram encontrados 12 anos úmidos (1988, 1990, 1991, 1992, 1993, 1998, 1999, 2006, 2007, 2012, 2013 e 2014) que correspondem aos valores entre o 3o quartil e o Vmáx, apenas 1 anos seco (2013) que corresponde aos valores entre o Vmín e 1o quartil (Figura 2). A maior quantidade e/ou frequência das observações úmidas, ocorreram ano de $2013(1.498,00 \mathrm{~mm}$ e 1.436,30 $\mathrm{mm}$ ) e ao mesmo tempo neste mesmo ano observa-se ocorrência de períodos secos (ausência de chuvas), o indica grande variabilidade/oscilação do clima na região, tal qual observado na Figura 2.

Pela Figura 3, a equação linear ajustada para 30 anos da precipitação pluvial total anual para as seis mesorregiões do Agreste Pernambucano, revela ao nível de 5\% de significância o coeficiente angular negativo $(-397,9)$, demonstrando uma tendência do decrescimento da chuva total anual da ordem de aproximadamente de - 397,9 mm no período de 30 anos, ou da ordem de -13,26 mm/ano. Os valores mostrados são consistentes quando comparados com estudos realizados pelo IPCC (Intergovernmental Panel on Climate Change), que constatou redução das chuvas na região Nordeste ao longo das décadas, por meio de modelos que simulam os efeitos das mudanças climáticas globais sobre climas regionais (Figura 3). 
Figura 3. Análise de regressão linear pela suavização dos dadas da precipitação pluvial total anual (mm), para a série de 1985 a 12 de julho de 2014 das seis mesorregiões do Agreste de Pernambucano.

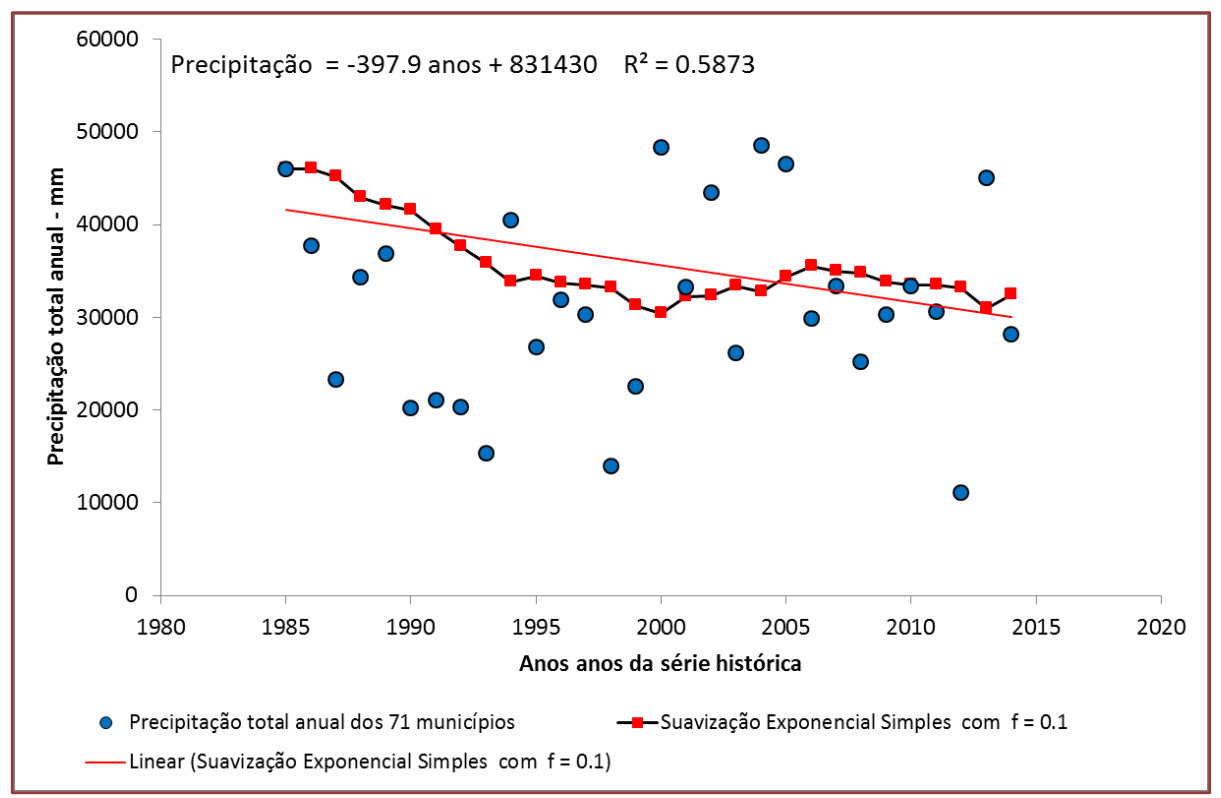

A Figura 4 corresponde aos valores dos coeficientes angulares da reta ajusta (tendência) aos dados da precipitação total anual para as seis mesorregiões (e os 71 municípios) do Agreste Pernambucano, usando o método da suavização para a série histórica estudada (janeiro de 1985 a 12 de julho de 2014).

Figura 4. Distribuição espacial dos valores dos coeficientes do angulares da reta que identificar as tendências da precipitação total anual, em mm/ano, para as mesorregiões do Agreste de Pernambucano, para a série de 1985 a 12 de julho de 2014.

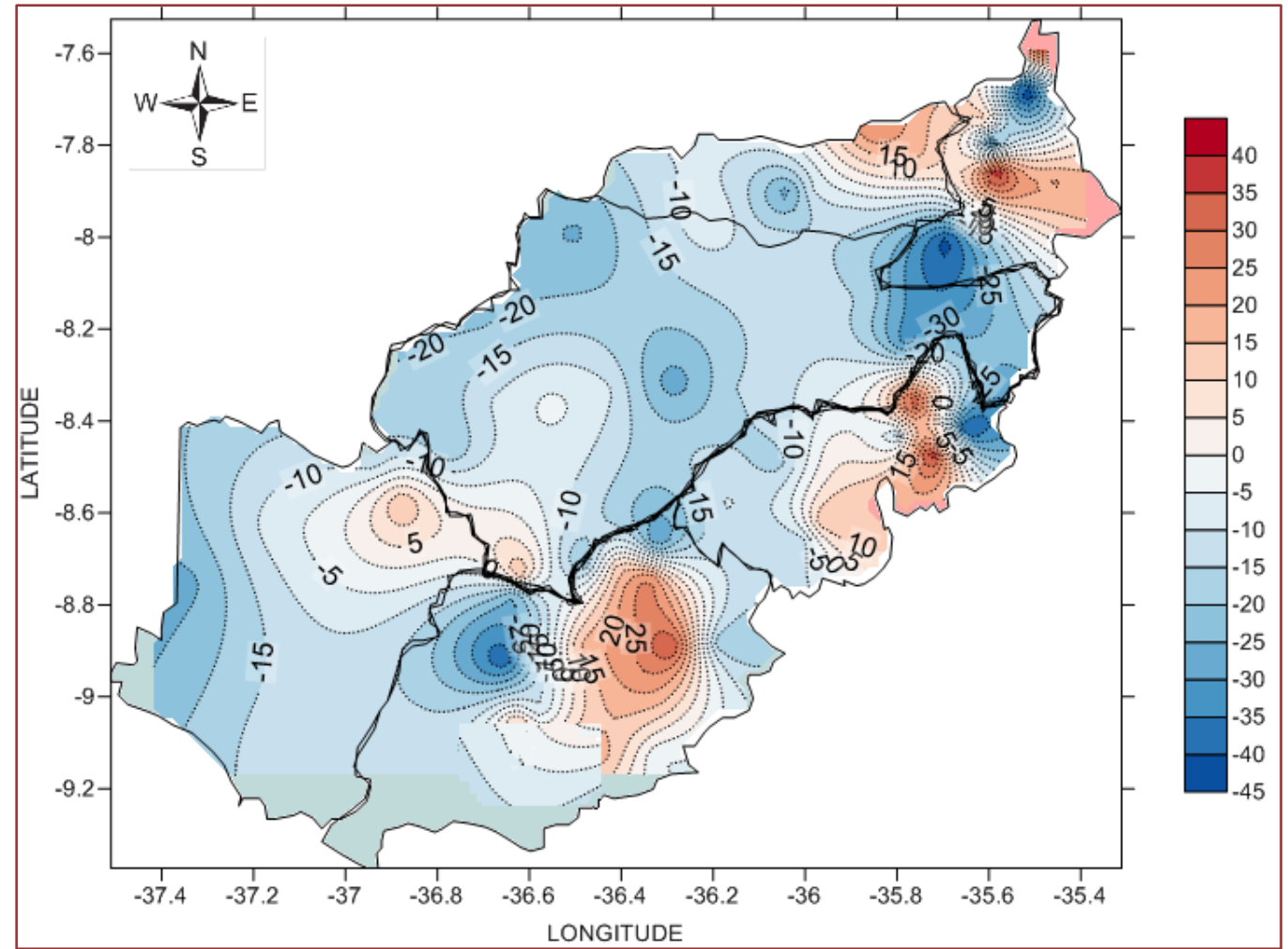


De modo geral observa-se uma tendência negativa (diminuição da precipitação) bastante expressiva e significativa sobre grande parte as mesorregiões (dos municípios) estudas, principalmente sobre as regiões do oeste do vale do Ipanema e do Ipojuca e do Alto Capibaribe, representados por valores negativos do coeficiente angular. A diminuição pluviométrica ratificado neste estudo mostrou-se irregular na escala temporal ao longo de todo o período estudado.

\section{CONCLUSÃO}

Constatou-se que ocorre presença de outliers em apenas dois anos, deixando os totais acima da média da precipitação pluviométrica. Verificou-se também número maior de eventos de anos mais úmidos do em mm/ano, para as mesorregiões do Agreste de Pernambucano.

Há uma tendência na redução da precipitação e toda a região estudada está sofrendo uma diminuição de volume pluviométrico do período avaliado e este pode acarretar danos graves aos biomas do semiárido do Nordeste Brasileiro, prejudicando as atividades econômicas e surgindo secas mais intensas na região. Este trabalho reforça a necessidade de um melhor planejamento e gerenciamento de recursos hídricos por parte de autoridades no intuito de minimizar efeitos negativos da redução do volume pluviométrico.

\section{AGRADECIMENTOS}

Agradecemos a FACEPE pelo financiamento de pesquisa, através do programa PIBIC, que concederam a bolsa de Iniciação Científica no período 2013-2015 para a realização deste trabalho.

\section{REFERÊNCIAS}

[1] FÉLIX, D. de O., SOUSA, I. F. de, NASCIMENTO, P. J. S. da S., SANTOS, D. N. dos. Avaliação da Tendência de Precipitação Pluviométrica anual no Estado de Sergipe. In: XVI Congresso Brasileiro de Meteorologia, Belém, 2010.

[2] GALVANI E.; LUCHIARI A. Critérios para classificação de anos com regime pluviométrico normal, seco e úmido. Aracajú VI Simpósio Brasileiro de Climatologia Geográfica, p. 20-29, 2004.

[3] LACERDA, F. F.; DIAS, H.; ASSAD, E. D.; SANTOS, A. de. A. Detecção de Sinais de Mudanças Climáticas para Algumas Localidades do Sertão do Pajeú - PE. In: XVI CBA - Congresso Brasileiro de Agrometeorologia, 2009, Belo Horizonte. Mudanças Climáticas, Recursos Hídricos e Energia para uma Agricultura Sustentável, 2009.

[4] LIMA, J.S.S. de; SAMUEL DE ASSIS SILVA, S.A. de; OLIVEIRA, R.B de; CECÍLIO, R.A; XAVIER, A.C. Variabilidade temporal da precipitação mensal em Alegre - ES. Revista Ciência Agronômica, v. 39, n. 02, p. 327-332, 2008

[5] RAMOS, A.M. Influência das mudanças climáticas devido ao efeito estufa na drenagem urbana de uma grande cidade. Tese (Doutorado), Universidade Federal de Pernambuco - UFPE, Recife, 2010, 160p.

[6] RAMOS, Y.S.; RIBEIRO, G.N.; ALCÂNTARA, H.M. Eventos de extremos mensais da precipitação na cidade do Recife/PE (1961-2010). Revista Verde de Agroecologia e Desenvolvimento Sustentável, (Mossoró - RN), v. 7, n. 5, p.59 - 66 , jan-dez, 2012 (Volume Especial)

[7] SANTOS, C. A. C. dos; BRITO, J. I. B. de; RAO, T. V. R.; MENEZES, H. E. A. Tendências dos índices de precipitação no Estado do Ceará. Revista Brasileira de Meteorologia, v. 24, n. 1, p. 39-47, 2009.

[8] SCHNEIDER, H.; SILVA, C.A. da. O uso do modelo box plot na identificação de anos-padrão secos, chuvosos e habituais na microrregião de dourados, Mato Grosso do Sul. Revista do Departamento de Geografia - USP, v. 24, p. 131-146, 2014.

[9] SILVA, R. O. B. Tendências de mudanças climáticas na precipitação pluviométrica no estado de Pernambuco. Dissertação (Mestrado Engenharia Civil), Universidade Federal de Pernambuco - UFPE, Recife, 2013, 95p.

[10] THEIL, H. A rank-inavariant method of Linear and polynomial regression analysis, I, II, III. Nederl Akad Wetensch Proc. 53: p. 386-392, 512-525, 1397-1412, 2000. 


\title{
Capítulo 20
}

\section{Análise cienciométrica sobre a dinâmica de serapilheira em ecossistemas semiáridos no brasil}

\author{
Brenna Hortins de Oliveira \\ Sérgio de Faria Lopes \\ Anderson Silva Pinto \\ Rubenice da Costa Correia \\ Larissa Barbosa da Silva ${ }^{5}$ \\ Wanderleya Kelliane Lemos Pimentel
}

Resumo: A Caatinga é o domínio brasileiro que mais sofre com ações antrópicas e estresse hídrico. A produção, acúmulo e decomposição da serapilheira é um dos principais mecanismos para o retorno de nutrientes nos ecossistemas. 0 objetivo deste trabalho foi realizar uma revisão sistemática de literatura, com base nas seguintes perguntas: (1) Houve um aumento de estudos sobre a serapilheira na Caatinga ao longo do tempo? (2) Quais os principais temas abordados desses estudos? (3) Quais os estados do nordeste do Brasil que mais publicaram? Por meio da base de dados do Scielo (ScientificElectronic Library Online), Web of Science e Scopus, através dos seguintes descritores em português: serapilheira and Caatinga and decomposição and nutrientes and espécies vegetais, e em inglês: litterand Caatinga. Ao todo foram encontradas 19 publicações, em oito periódicos científicos, sendo a maior concentração no estado da Paraíba, com nove publicações. No estado da Bahia e Ceará foram encontradas apenas uma publicação cada, apesar da vegetação do estado da Bahia ser composta de $54 \%$ de Caatinga. Verificou-se um aumento de pesquisas sobre a serapilheira na Caatinga, principalmente no ano de 2015. A maioria dos trabalhos abordam as questões de decomposição, deposição, aporte, acúmulo, produção e a relação da serapilheira com a pluviometria. Apesar da escassez de publicações sobre essa temática, nos últimos anos houve um aumento na quantidade de trabalhos realizados, principalmente no ano de 2015, que houve sete publicações das 19 encontradas. Os estudos sobre a serapilheira na Caatinga mostraram ser recentes, porém, é de grande importância a abordagem e entendimento desse mecanismo fundamental de retorno nutricional ao sistema.

Palavras-Chave: Caatinga; Decomposição; Nutrientes. 


\section{INTRODUÇÃO}

A vegetação da Caatinga apresenta, em sua maioria, espécies caducifólias que perdem toda ou parcialmente a folhagem, como mecanismo fisiológico de adaptação aos períodos de escassez hídrica. Geralmente as camadas mais superficiais do solo nesses ambientes possuem acúmulo de resíduos orgânicos provenientes da queda de folhas, galhos, órgãos reprodutivos, além de corpos e dejetos animais (OLSON, 1963; COSTA et al. 2010).

Essa deposição de matéria orgânica promove a formação de uma camada superficial de resíduos denominada serapilheira, responsável por desempenhar papel fundamental em processos relacionados a dinâmica florestal (GODINHO et al. 2013; HENRIQUES, 2016), como a ciclagem de nutrientes e alterações das condições microclimáticas do solo (CALDEIRA et al. 2008; CALDEIRA et al. 2010).

A camada orgânica formada pela serapilheira é um dos principais agentes responsáveis pela ciclagem de nutrientes em ecossistemas florestais tropicais, já que a interação entre serapilheira e solo são os locais de todas as etapas da decomposição da matéria orgânica e da ciclagem de nutrientes (PRITCHETT, 1980). Quando folhas, galhos e raízes são incorporados a serapilheira e sofrem o processo de decomposição, ocorre liberação desses nutrientes ao solo e, consequentemente, a disponibilização para as plantas (GODINHO et al. 2014).

A quantidade de nutrientes devolvidos ao solo pela deposição de serapilheira é variável edependente da riqueza de espécies, do grau de deciduidade foliar e da concentração de nutrientes presentes nas folhas após sua senescência (ZALAMEA; GONZALES, 2008). A serapilheira torna-se importante na reincorporação de nutrientes, pois a disponibilidade destes tende a diminuir a medida que os solos tornam-se mais velhos (HEDIN et al. 2003, URIARTE et al. 2015), até porque, os nutrientes essenciais não são estáticos já que os ecossistemas os perdem através de emissões gasosas, lixiviação, volatização, entre outros fatores (WRIGHT et al. 2011).

Nesse sentido é premente a necessidade de mais estudos sobre a vegetação e a serapilheira. Por isso, trabalhos detalhados sobre a produção da serapilheira é importante na busca de informações sobre a compreensão da função da mesma dentro do ecossistema (HENRIQUES, 2016). Deste modo, objetivou-se realizar um estudo cienciométrico sobre a dinâmica da serapilheira na Caatinga, assim, as seguintes perguntas foram formuladas para o melhor entendimento: (1) Houve um aumento de estudos sobre a serapilheira na Caatinga ao longo do tempo? (2) Quais os principais temas abordados desses estudos? (3) Quais os estados do nordeste do Brasil que mais publicaram?

\section{METODOLOGIA}

Trata-se de uma revisão sistemática de literatura a partir das bases de dados: Scielo (ScientificElectronic Library Online), Web of Science e Scorpus, identificando a literatura ordenada nos idiomas português e inglês, utilizando os descritores: serapilheira, decomposição, caatinga. Foram listados artigos publicados até 2017 que abordaram a temática. Após a obtenção das listas de trabalhos publicados, foi feita uma triagem para retirar as publicações repetidas de forma a obter as publicações totais nas bases pesquisadas, considerando somente os artigos publicados em revistas indexadas que abordam a temática.

De posse dos documentos, mediante a revisão da literatura obteve-se: ano de publicação dos artigos referentes a temática serapilheira e os estados do Nordeste com maior número de trabalhos publicados.

\section{RESULTADOS E DISCUSSÃO}

A partir do levantamento de dados para a revisão sistemática de literatura foi encontrado um total de 29 publicações que abordam a temática em questão. Alguns dos trabalhos não tinham a serapilheira na Caatinga como foco principal, e apenas 19 atenderam as exigências da busca. Foram encontrados quatro artigos sobre serapilheira na base de dados Scielo, oito artigos no Scopus e sete na Web of Science. Dentre todas as bases utilizadas, foram encontrados oito periódicos científicos, sendo a Revista Árvore o periódico com maior número de publicações (Figura 1). 
Figura 1. Número de publicações por periódicos científicos. FLORAM = Floresta e Ambiente; BJB = BrazilianjournalofBiology.

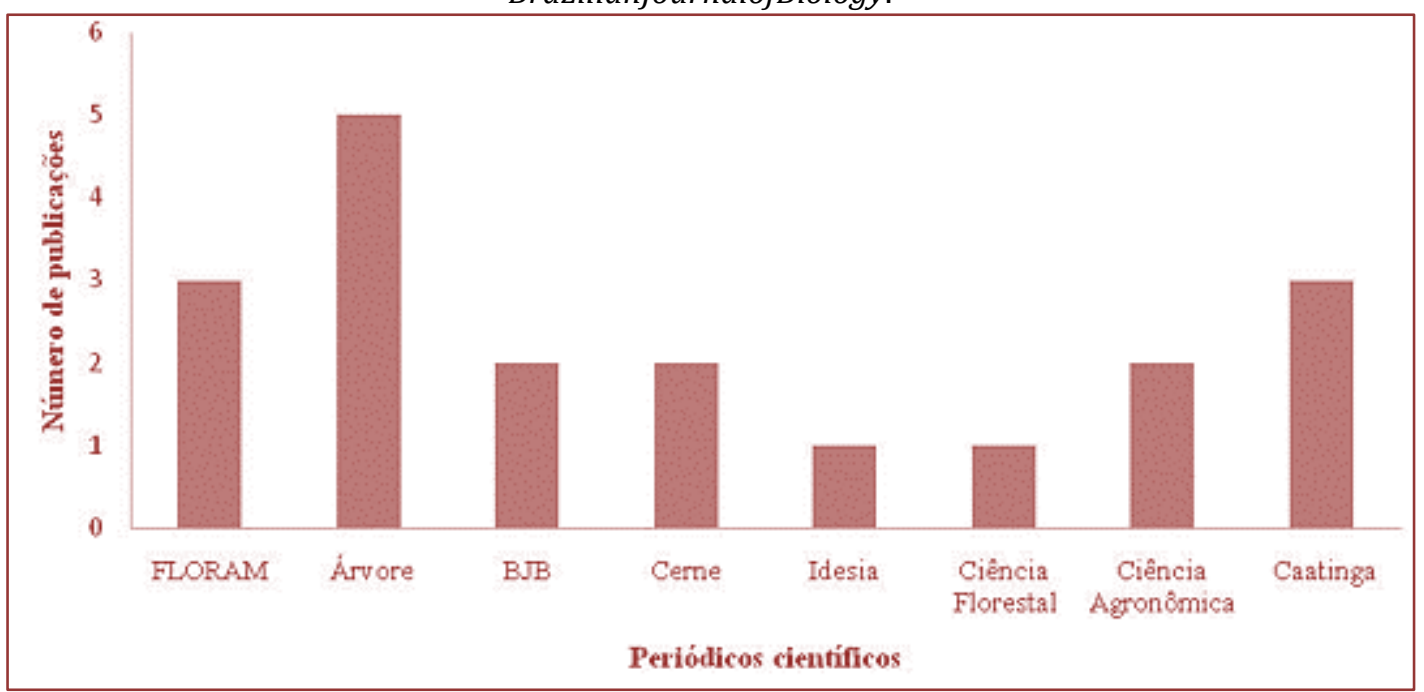

Os estudos sobre serapilheira na região da Caatinga ainda são iniciais. Foram publicados nos últimos oito anos, a partir de 2009, com um pico em 2015 com sete publicações (Figura 2). Com base nos dados apresentados, é de extrema importância que novos estudos sejam realizados, já que a ciclagem de nutrientes em ecossistemas naturais poderá, em médio e longo prazo, fornecer subsídios para melhor entendimento das relações existentes em uma determinada área e/ou região.

De posse de informações relativas à deposição, acúmulo e decomposição da serapilheira é possível definir estratégias para o manejo sustentável de determinado ecossistema, a exemplo da Caatinga (FERREIRA, 2011), já que é um dos domínios brasileiros no qual se registram os maiores índices de degradação, associada, principalmente, à supressão da vegetação para produção energética e prática da agricultura de subsistência, ocasionando interferências na ciclagem de nutrientes (HOLANDA, 2017).

Figura 2. Número de artigos sobre a temática ao longo do tempo.

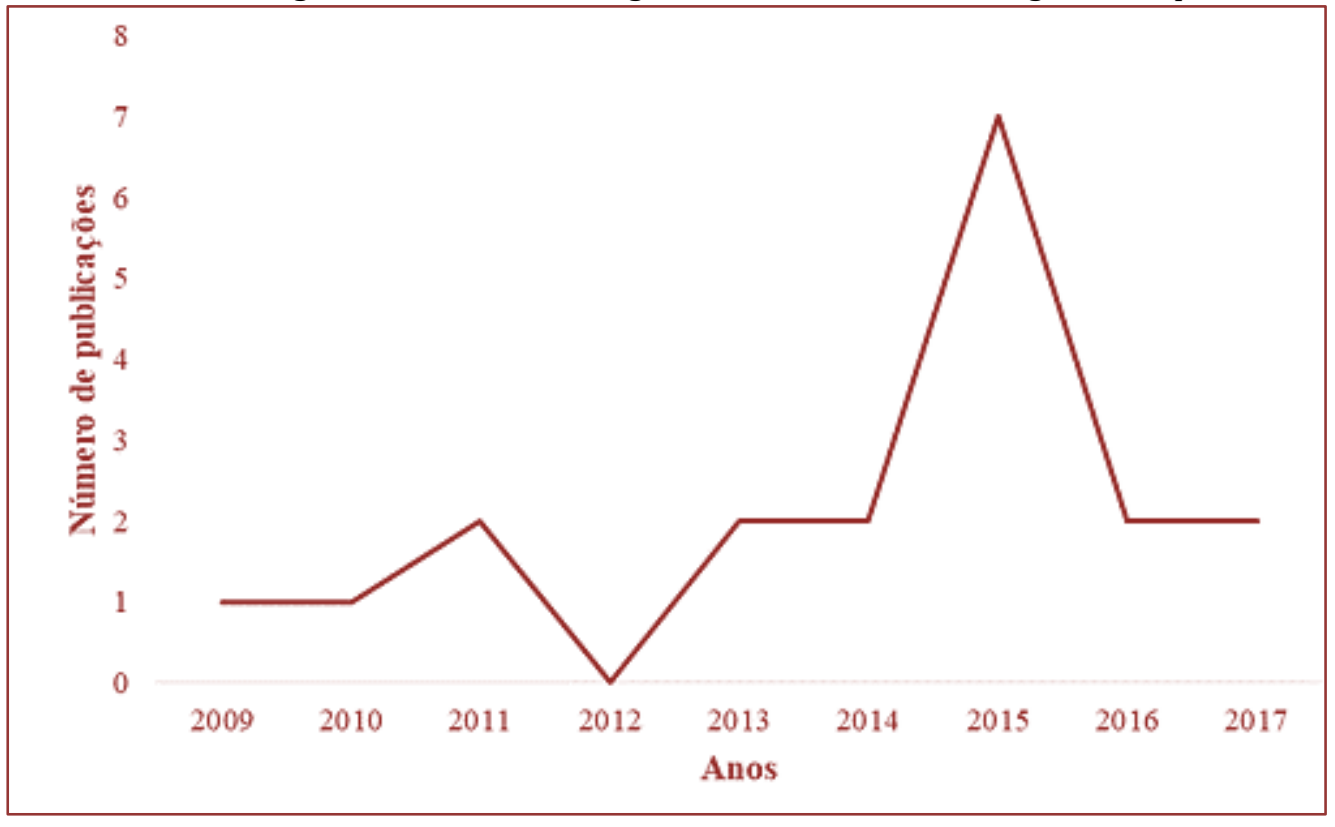


Pesquisas sobre ciclagem de nutrientes em florestas antropizadas também permitem inferências sobre as espécies com maior ou menor capacidade de reciclagem de nutrientes e seu potencial para recuperação de áreas degradadas. Assim, são disponibilizadas informações sobre a taxa de produtividade e a quantidade de nutrientes que entram naturalmente no sistema solo-planta, o que é de grande significado em atividades de recuperação de áreas degradadas, proteção de fontes hídricas superficiais ou mesmo em projetos de reflorestamento em solos distrófico (SANTANA; SOUTO, 2011).

Por ser um fator chave na manutenção dos nutrientes no ecossistema, o processo de deposição da serapilheira, incluindo as taxas anuais de queda do material decíduo e o processo de decomposição desse material, devem ser mais amplamente estudados e conhecidos (SANTANA; SOUTO, 2011). Estudos de ciclagem de nutrientes no bioma Caatinga podem contribuir para o melhor entendimento dos processos ecológicos nesse ecossistema (LIMA, 2015). Os principais objetivos dos trabalhos encontrados estão associados com a decomposição, deposição, aporte e acúmulo e a influência da sazonalidade na produção de serapilheira (Figura 3).

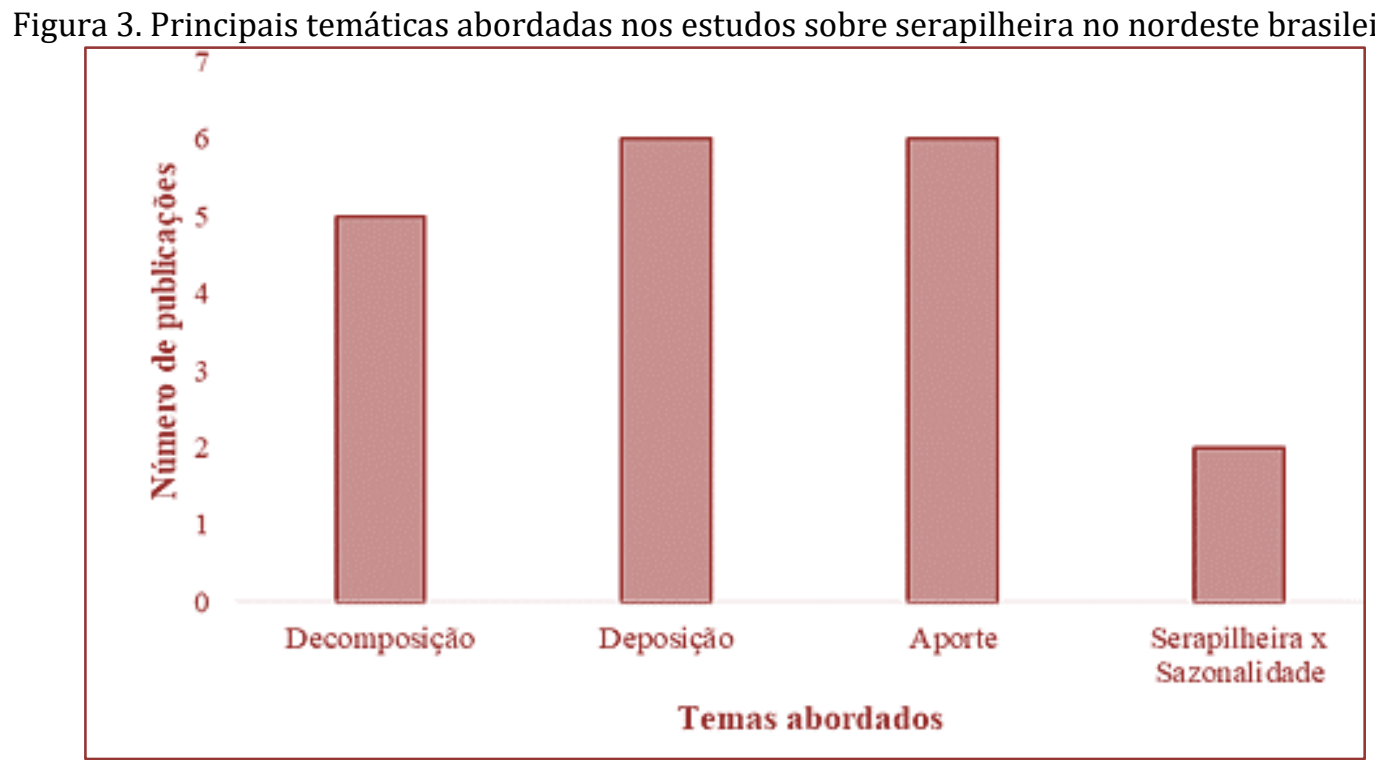

A elaboração de mais estudos sobre a temática é de extrema importância para a somatórias de informações para futuros projetos com vista à conservação e preservação do bioma Caatinga, pois, somente através da junção de dados será possível ordenar e generalizar os resultados de caráter isolado, de forma que se construa um modelo geral da função da serapilheira dentro do ecossistema (SILVA, 2017).

Foram encontrados seis estudos sobre a deposição da serapilheira. De acordo com Moura (2016), a deposição de serapilheira em ambientes florestais é uma das principais vias de transferência no fluxo de nutrientes, sendo fundamental para a sustentabilidade dessas comunidades. Além disso, a serapilheira é uma das principais fontes biológicas de nutrientes para vegetais e microrganismos presentes no solo e sua decomposição é uma etapa fundamental no ciclo biogeoquímico (HOLANDA, 2015), neste trabalho, estudos sobre a decomposição da serapilheira está entre os três assuntos mais abordados nas bibliografias encontradas nos últimos oito anos. Nesse sentido, entender o funcionamento e as variáveis que promovem maior ou menor estabilidade a uma comunidade vegetal e/ou animal é essencial para que se possa intervir sem, no entanto, degradá-la; assim são os estudos de deposição e decomposição de serapilheira em ambientes florestais (LOPES, 2009)

A Paraíba é o estado onde foi encontrado o maior número de pesquisas ligadas ao tema, com o total de nove publicações (Figura 4). Há uma correlação positiva em relação ao domínio da Caatinga na área total do estado, que corresponde a $92 \%$ e a quantidade de trabalhos publicados. Porém, foram encontradas apenas três publicações para os estados do Rio Grande do Norte e Ceará, apesar da Caatinga corresponder a $95 \%$ e $100 \%$ do estado, respectivamente. Para o estado do Piauí (63\% de Caatinga) foram encontradas duas publicações e Pernambuco (83\%) e Bahia (54\%) foram encontradas apenas uma publicação cada (IBGE, 2004). 0 restante dos estados não apresentou estudos sobre serapilheira (Sergipe, Alagoas e Maranhão). 
Figura 4. Número de estudos sobre serapilheira divididos por estados do Nordeste (os estados não representados no gráfico não apresentaram publicações no período definido).

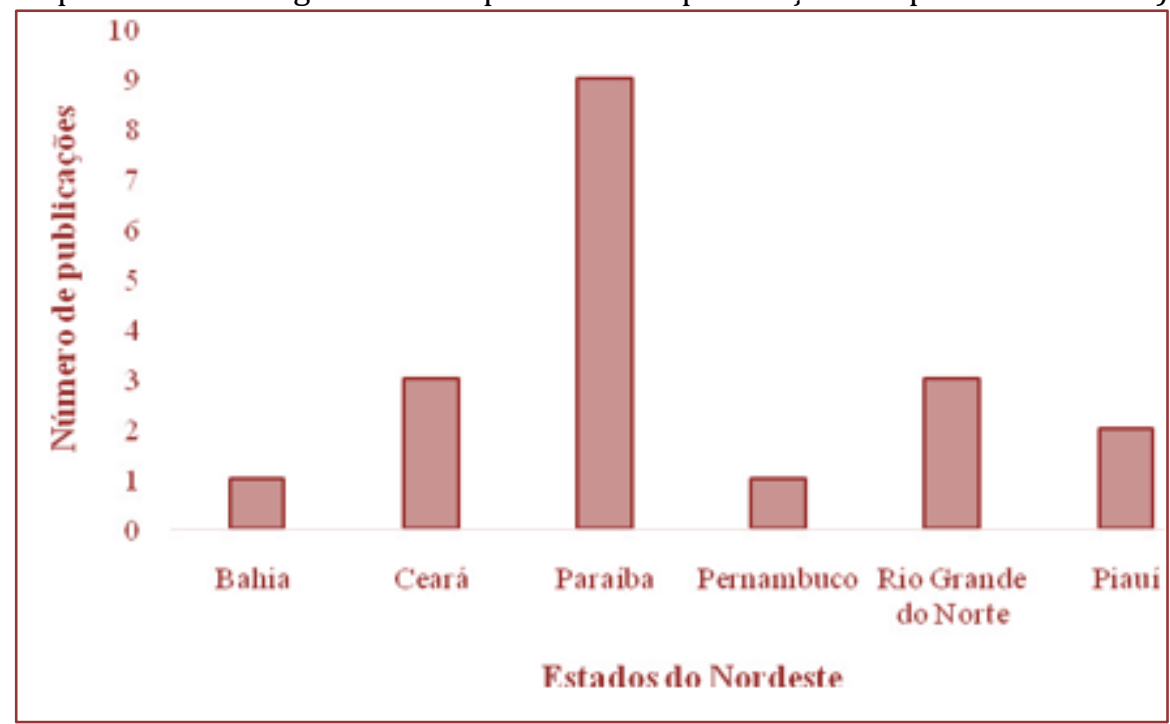

\section{CONCLUSÃO}

Foi encontrado um total de 19 artigos que abordam especificamente a temática. As publicações em relação a serapilheira no domínio Caatinga têm sido maiores a partir do ano de 2015. Os estudos sobre esse processo são tardios e ainda escassos na região da Caatinga. A partir das bases utilizadas, oito periódicos científicos foram encontrados, entre eles o que apresentou o maior número de publicações foi a Revista Árvore, com cinco publicações. Houve um aumento no número de pesquisas nos últimos anos, o que indica que essa área poderá ganhar uma maior visibilidade com o decorrer do tempo. No entanto, o presente resultado indica que alguns estados do Nordeste do Brasil (Sergipe, Alagoas e Maranhão) ainda não publicaram artigos com a temática. Os principais objetivos dos trabalhos levantados estavam ligados a trabalhos sobre decomposição, deposição aporte e acúmulo de serapilheira e a influência da sazonalidade na produção de serapilheira que são etapas importantes nesse processo fundamental na ciclagem de nutrientes.

0 presente trabalho evidencia uma lacuna relevante de mais informações sobre a dinâmica de serapilheira em ecossistemas semiáridos, esclarecendo a importância desses estudos para a melhor compreensão dos processos mantenedores da ciclagem de nutrientes, o que pode refletir na montagem de comunidades vegetais na Caatinga.

\section{FOMENTO}

CAPES, CNPq, UEPB.

\section{REFERÊNCIAS}

[1] Cauê De Holanda, Alan et al. Aporte de Serapilheira e Nutrientes em uma Área de Caatinga. Ciência Florestal, v. 27, n. 2, 2017.

[2] Caldeira, Mvw et al. Ciclagem de nutrientes, via deposição e acúmulo de serapilheira, em ecossistemas florestais. Chichorro, JF; Garcia, Go; Bauer, mo; Caldeira, MVW Tópicos em ciências florestais. Visconde do Rio Branco: Suprema, p. 57-82, 2010.

[3] Costa, Caio Cesar de Azevedo et al. Análise comparativa da produção de serapilheira em fragmentos arbóreos e arbustivos em área de caatinga na FLONA de Açu-RN. 2010.

[4] Da Silva Santana, José Augusto; Silva Souto, Jacob. Produção de serapilheira na Caatinga da região semi-árida do Rio Grande do Norte, Brasil. Idesia (Arica), v. 29, n. 2, p. 87-94, 2011.

[5] De Medeiros Silva, WhendersonThalmer et al. Deposição de serapilheira em áreas de Caatinga no Núcleo de Desertificação do Seridó. Agropecuária Científica no Semiárido, v. 12, n. 4, p. 383-390, 2017. 
[6] Ferreira CD. Deposição, acúmulo e decomposição de serapilheira em área de caatinga preservada [monografia]. Campina Grande: Centro de Saúde e Tecnologia Rural, Universidade Federal da Paraíba; 2011.

[7] Godinho, Tiago de Oliveira et al. Quantificação de biomassa e nutrientes na serapilheira acumulada em trecho de Floresta Estacional SemidecidualSubmontana, ES. 2014.

[8] Hedin, Lars O.; Vitousek, Peter M.; Matson, Pamela A. Nutrient losses over four million years of tropical forest development. Ecology, v. 84, n. 9, p. 2231-2255, 2003.

[9] Henriques, Í. GN et al. Acúmulo, deposição e decomposição de serrapilheira sob a dinâmica vegetacional da Caatinga em Unidade de Conservação. Revista Verde de Agroecologia e Desenvolvimento Sustentável, v. 11, n. 1, p. 8489, 2016.

[10] Holanda, Alan Cauê et al. Decomposição da serapilheira foliar e respiração edáfica em um remanescente de Caatinga na Paraíba. Revista Árvore, v. 39, n. 2, p. 245-254, 2015.

[11] Ibge (Instituto Brasileiro de Geografia e Estatística). Mapa de biomas do Brasil: primeira aproximação. IBGE, Rio de Janeiro, 2004.

[12] Lima, Rissele Paraguai et al. Aporte e decomposição da serapilheira na Caatinga no sul do Piauí. 2015.

[13] Lopes, José Fredson Bezerra et al. Deposição e decomposição de serapilheira em área da Caatinga. Revista Agro@ mbiente On-line, v. 3, n. 2,p. 72-79, 2010.

[14] Moura, Matheus Magalhães Silva et al. Produção de serapilheira e suas frações em área da Caatinga no Semiárido Tropical. Revista Brasileira de Gestao Ambiental e Sustentabilidade, v. 3, n. 5, p. 199-208, 2016.

[15] Olson, Jerry S. Energy storage and the balance of producers and decomposers in ecological systems. Ecology, v. 44, n. 2 , p. 322-331, 1963.

[16] Pritchett, William L. Properties and management of forest soils. Soil Science, v. 129, n. 6, p. 389, 1980.

[17] Uriarte, Maria et al. Trait similarity, shared ancestry and the structure of neighbourhood interactions in a subtropical wet forest: implications for community assembly. Ecology letters, v. 13, n. 12, p. 1503-1514, 2010.

[18] Wright, S. Joseph et al. Potassium, phosphorus, or nitrogen limit root allocation, tree growth, or litter production in a lowland tropical forest. Ecology, v. 92, n. 8, p. 1616-1625, 2011.

[19] Zalamea, Marcela; González, Grizelle. Leaffall phenology in a subtropical wet forest in Puerto Rico: from species to community patterns. Biotropica, v. 40, n. 3, p. 295-304, 2008. 


\section{Capítulo 21}

\section{Avaliação e mensuração dos efeitos da regularização fundiária para o bairro Manoel Domingos - Pau dos Ferros/rn}

\section{Hugo Leonardo Pontes Nunes}

Cícero de França Neto

Almir Mariano de Sousa Júnior

Resumo: No Brasil, atualmente, é comum observar como o planejamento urbano obtém resultados negativos no que se refere ao crescimento desordenado que perpassa dos maiores aos menores municípios. A implementação de zonas periféricas, apesar de ocorrer com maior intensidade em grandes centros, acontece também nos menores municípios, devido a autoconstrução de loteamentos irregulares em condições perimetrais. Estes fatores são resultado do intensivo crescimento urbano informal no século XX. Neste período surgiram diversos assentamentos irregulares, reflexo da superlotação daqueles que já existiam. Neste sentido, a regularização fundiária surge como um importante instrumento no acesso à moradia digna. Mediante esse contexto, insere-se a realidade do conjunto Manoel Domingos, localizado no município de Pau dos Ferros-RN. Desse modo, caracteriza-se como objetivo do presente trabalho analisar os impactos positivos para a população do referido bairro quanto ao processo de regularização fundiária proposto para o mesmo pelo Programa de Acesso à Terra Urbanizada, da Universidade Federal Rural do Semi-Árido - UFERSA, em parceria com o Ministério da Educação e das Cidades, além dos contextos de garantias jurídicas e sociais imbuídos por esta metodologia hoje fomentadas de acordo com a Lei 13.465/2017 de regularização fundiária rural e urbana.

Palavras-chave: Planejamento urbano, Regularização fundiária, Habitabilidade. 


\section{INTRODUÇÃO}

As discussões acerca do planejamento urbano é algo recorrente no cenário brasileiro, somando resultados negativos que implicam em problemas gerados pelo crescimento urbano desornado que aconteceu no país no decorrer do século XX, adversidade cotidiana que perpassa em municípios de pequeno e grande porte. As áreas periféricas ganham destaque, caracterizando-se como zonas que sofrem descaso dos órgãos públicos. Esse desinteresse dos órgãos competentes acaba gerando os mais diversos problemas para a população que vive nessas localidades, estes problemas englobam elementos básicos como investimento em saúde, educação, lazer, segurança e moradia digna, além disso, essas periferias situam-se em assentamentos irregulares, surgindo uma nova problemática, desta vez, envolvendo aspectos jurídicos, sociais e ambientais. Dentro desta realidade, a regularização fundiária aparece como um instrumento importante na promoção da cidadania, agindo em paralelo à outras políticas públicas, através de um conjunto de medidas jurídicas, urbanísticas, ambientais e sociais, solucionando problemas de assentamentos irregulares, como também a titulação de posse dos seus moradores, com isso, garantindo o direito social à moradia digna, conforme a Lei $\mathrm{n}^{\circ}$ Lei $\mathrm{n}^{\circ} 13.465 / 2017$. Dentro desta linha de pesquisa, esse trabalho foi desenvolvido no conjunto Manoel Domingos, situado no município de Pau dos Ferros, no interior do Rio Grande do Norte. Abaixo, na Figura 01, a localização da cidade no mapa do Rio Grande do Norte, e uma poligonal traçando o perímetro do conjunto Manoel Domingos.

FIGURA 01: Localização do conjunto Manoel Domingos no município de Pau dos Ferros RN

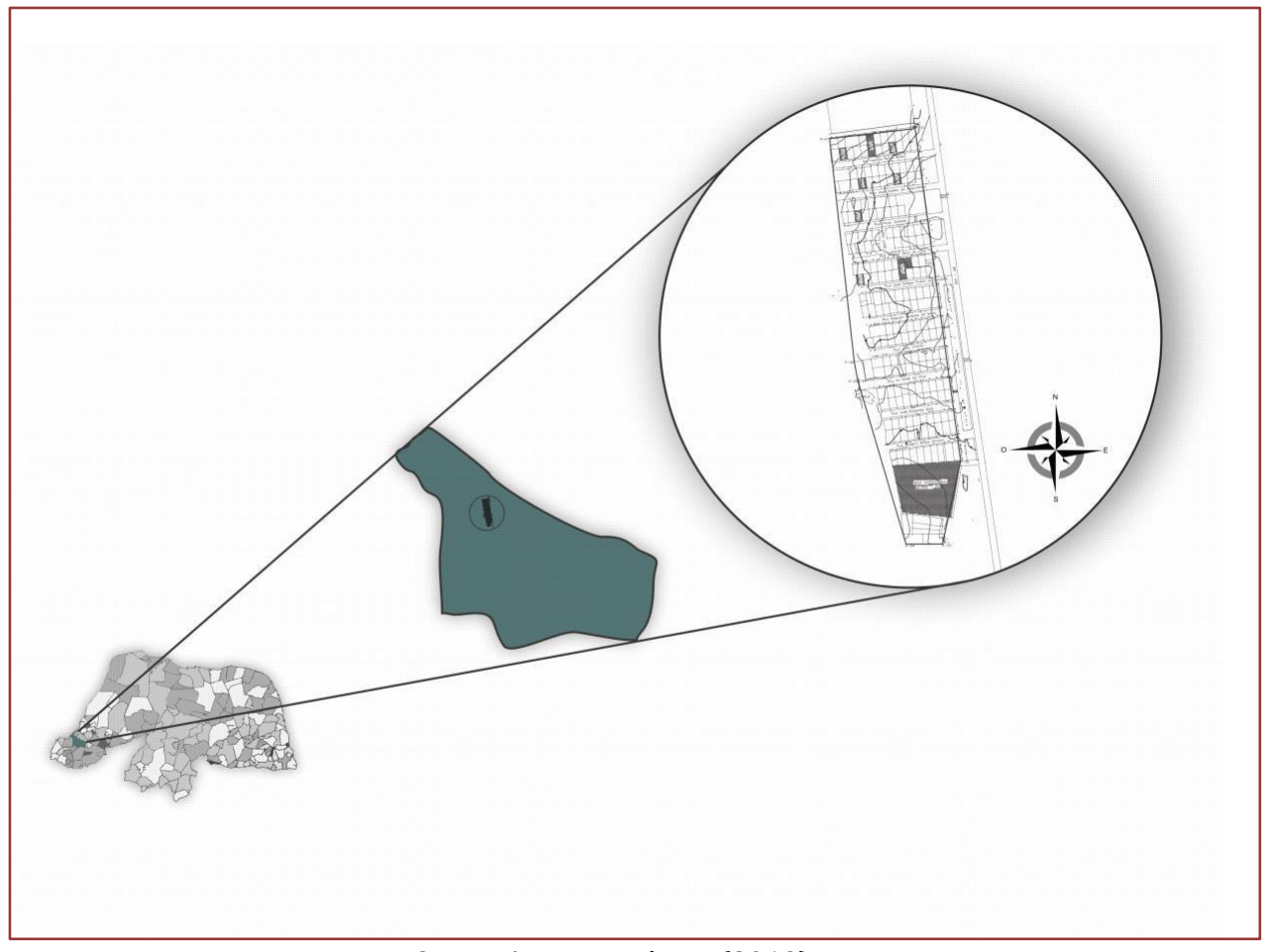

FONTE: Autoria própria (2019) 
Foi realizado um estudo prévio acerca do núcleo Manoel Domingos para o processo de regularização fundiária de interesse social no mesmo, abrangendo imóveis urbanos, ocupados por população de baixa renda, especialmente para moradia. 0 trabalho foi conduzido pelo Programa Acesso à Terra Urbanizada, da Universidade Federal Rural do Semi-Árido (UFERSA). No Brasil, em muito já se evoluiu em questão de legislações, entretanto existem ainda diversos caminhos a serem percorridos em busca de solucionar os problemas causados pelo desordenamento territorial no âmbito do urbanismo, seja na gestão ou planejamento urbano considerando a regularização fundiária como elemento imprescindível para o direito à moradia, como consta na Lei 13.465/2017, cujos avanços apontam para uma desburocratização deste processo.

Esse capítulo possui como objetivo compreender toda a área de estudo no que se refere a condicionantes como infraestrutura, serviços urbanos, dominialidade do ocupante para com a edificação, entender a realidade do local e em seguida mensurar como a Regularização Fundiária será capaz de transformar estes resultados encontrados.

\section{METODOLOGIA}

Para desenvolvimento desta pesquisa, foram utilizadas as seguintes ferramentas: pesquisas de cunho bibliográfico e pesquisas de campo englobando a aplicação de formulários de cadastro social. Esse formulário, primeiramente possui o intuito de registrar e identificar a dominialidade do morador à edificação, esclarecer a realidade da região no qual foi aplicado, no tocante a questões de infraestrutura básica, serviços urbanos em geral e condições socioeconômicas da população. Essa linha metodológica permite associar os diferentes agentes envolvidos nesse contexto, possibilitando ao pesquisador um contato direto com o seu objeto de estudo, caracterizando-se como um estudo de caso e uma pesquisa de caráter exploratório. A partir disso, o diagnóstico dos condicionantes sociais e ambientais torna-se viabilizado pelos gráficos obtidos pela aplicação dos questionários. Fundamentado nisto, torna-se possível estabelecer essa correlação com as modificações benéficas que devem ocorrer após a realização do processo de regularização fundiária.

\section{RESULTADOS E DISCUSSÃO}

Por tratar-se de um processo concluso, a presente pesquisa aponta como resultados um conjunto de melhorias que podem ser aplicadas à região do Conjunto Manoel Domingos. O questionário socioeconômico e o cadastro físico mostraram com clareza os maiores problemas encontrados naquela localidade.

0 Gráfico 01 mensura as situações que foram encontrados os imóveis na pesquisa de campo, em um total de 206 lotes. 
Gráfico 01: Situação do imóvel

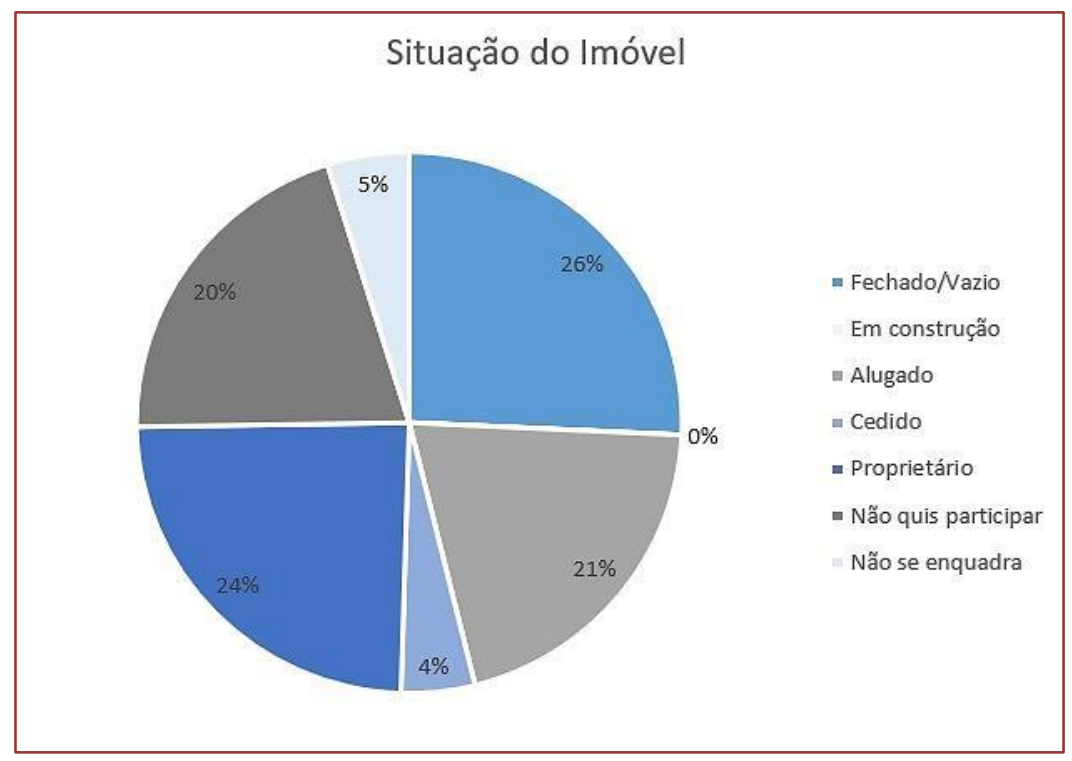

FONTE: Autoral (2019)

Dentre eles, têm-se as condições de habitabilidade como um todo. No que se refere a dominialidade, os moradores foram questionados se possuíam alguma documentação, que neste caso seria qualquer documento que comprovasse que o mesmo morava naquele imóvel há mais de cinco anos, conforme a legislação vigente entre os anos de 2014 e 2017. Os resultados estão no Gráfico 02.

Gráfico 02: Documentação que comprove moradia

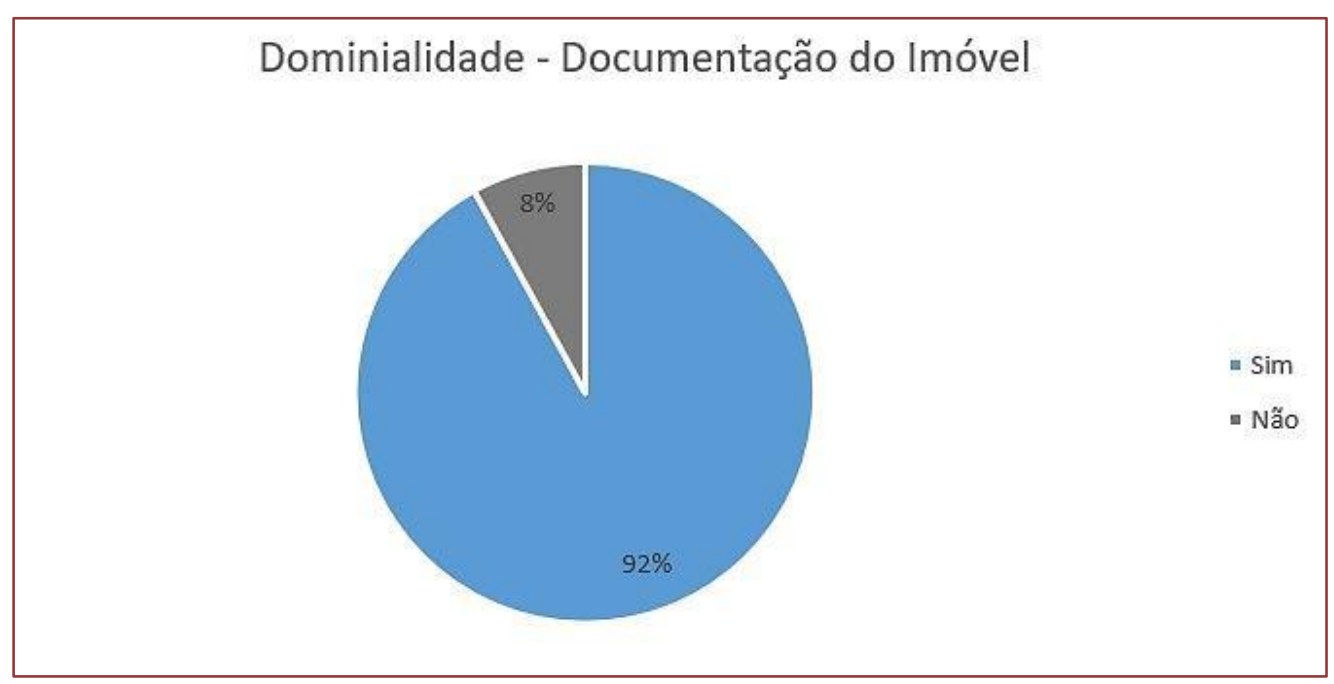

FONTE: Autoral (2019)

Após o documento de comprovante de residência, os moradores foram questionados se possuíam registro no cartório com o objetivo de saber a situação do imóvel. 0 Gráfico 03 demonstra com clareza a porcentagem de moradores que apresentaram a escritura particular do imóvel. 
Gráfico 03: Registro no cartório

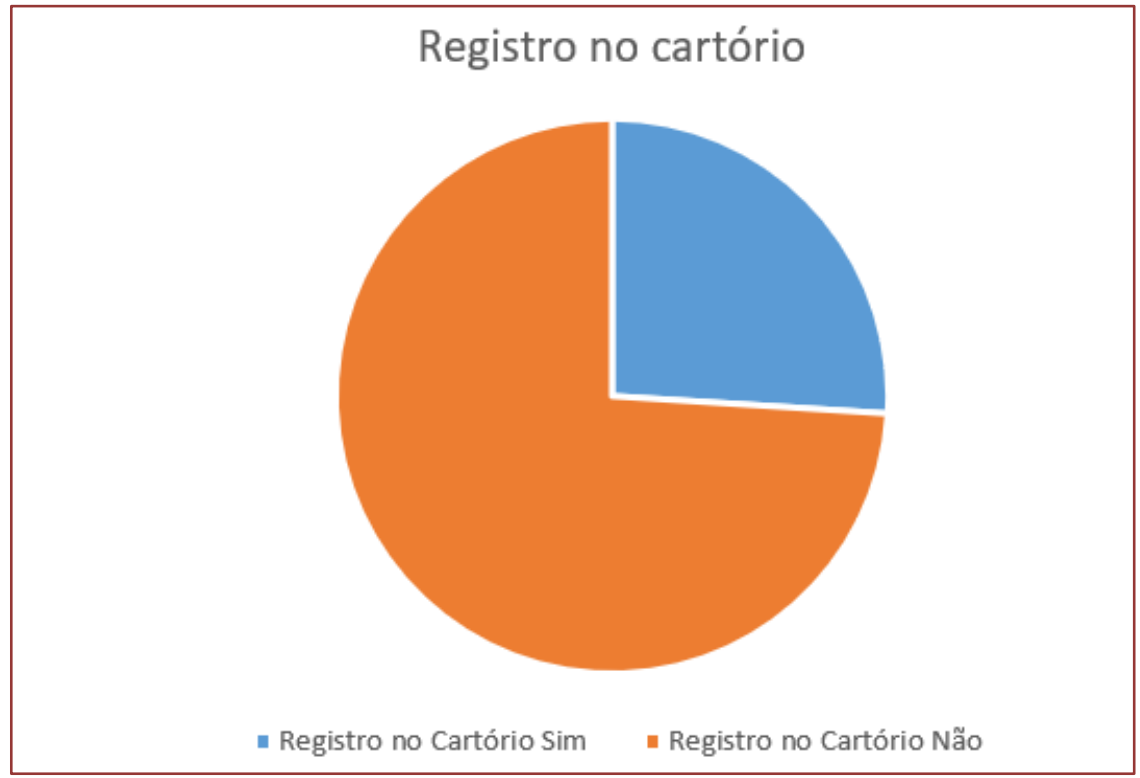

FONTE: Autoral (2019)

Foram 176 entrevistados, somando a renda de todos eles, o valor encontrado foi de $\mathrm{R} \$ 58.192,08$, totalizando uma renda média de $\mathrm{R} \$ 330,64$. Aliando esses valores a quantidade de assentamentos regulares, é possível notar com mais clareza que a população vive em pobreza. A partir disto, os próximos gráficos comprovam que conjuntos nessas condições carecem de serviços públicos mais atenciosos e dispostos a solucionar de vez os problemas encontrados.

Gráfico 04: Saneamento básico

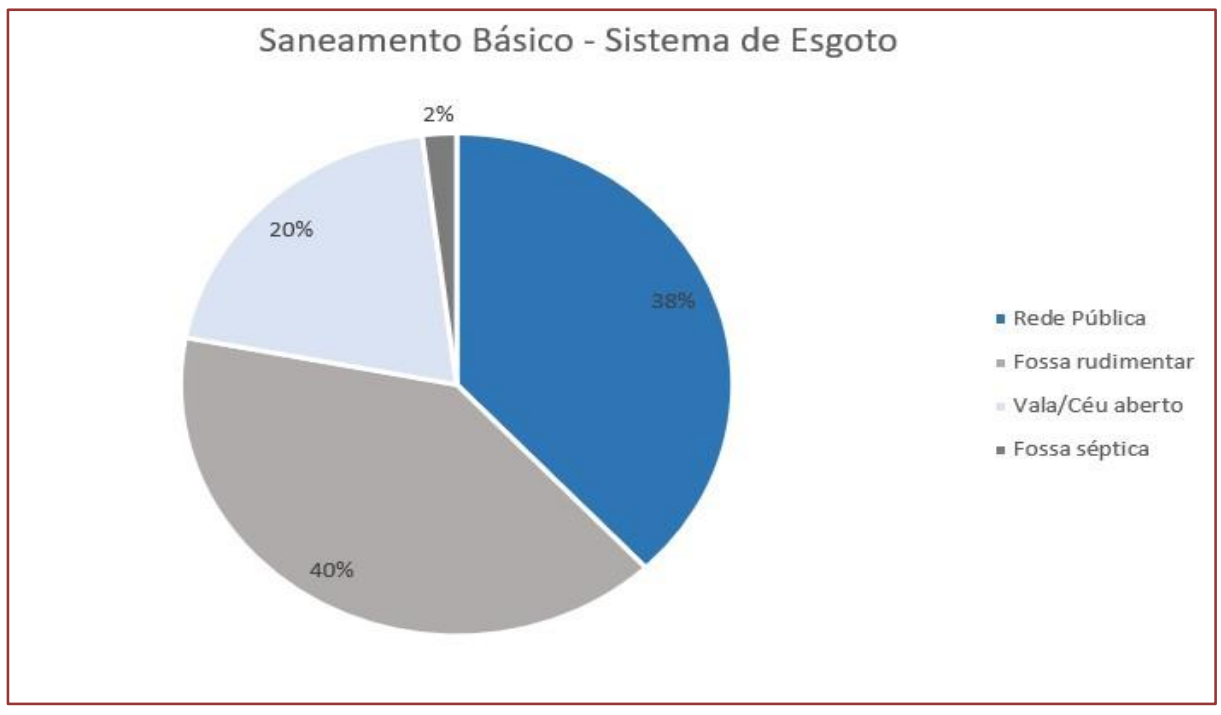

FONTE: Autoral (2019) 
A falta de saneamento básico é um problema que afeta todo o território nacional, segundo o Instituto Trata Brasil (2018), apenas 45\% do esgoto brasileiro passa por tratamento e $48,1 \%$ dos brasileiros não possui coleta de esgoto, utilizando maneiras alternativas para lidar com os dejetos, é o caso de conjuntos como o Manoel Domingos, utilizando fossa rudimentar e esgoto ao céu aberto.

Quando o assunto foi abastecimento de água, a grande maioria da população é abastecida pela rede pública (CAERN). 0 grande problema, neste caso, fica por conta da seca que castiga a região e este abastecimento chegando nas residências apenas de quinze em quinze dias.

Gráfico 05: Abastecimento de água

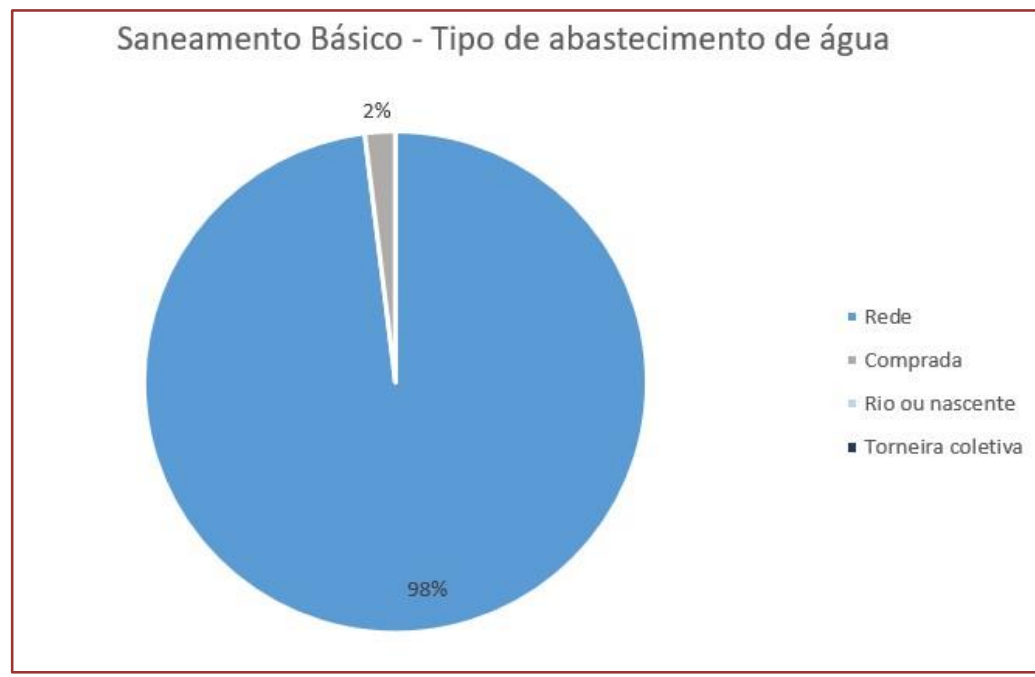

FONTE: Autoral (2019)

Gráfico 06: Coleta de lixo

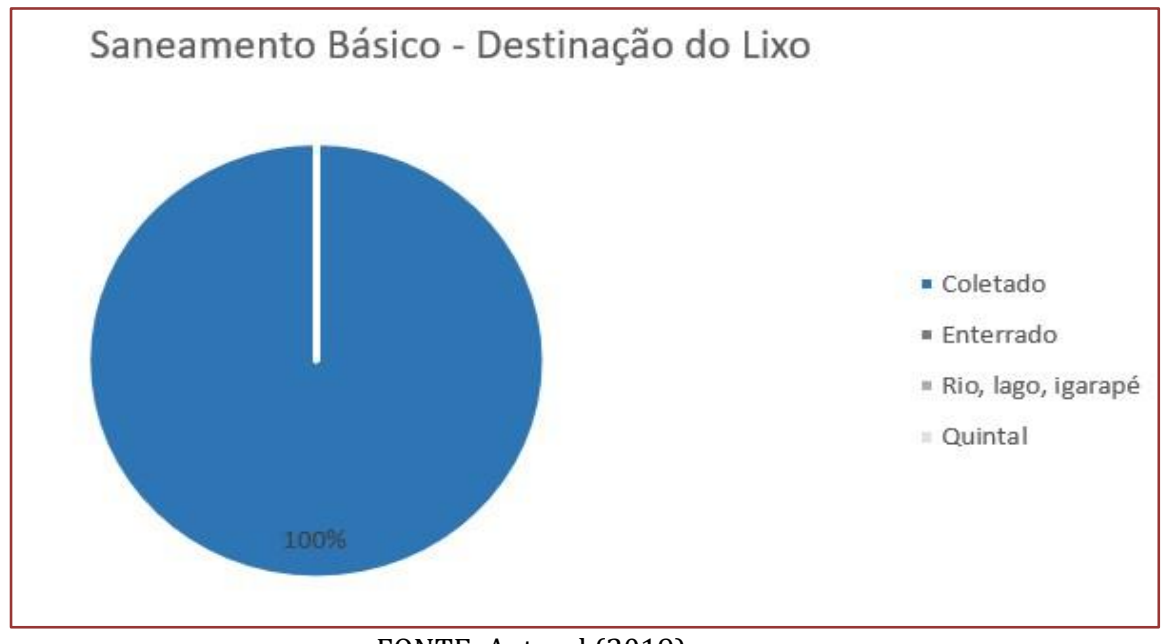

FONTE: Autoral (2019)

Mesmo existindo muitos problemas já descritos anteriormente, o saneamento básico do bairro não é completamente ruim. Todo o lixo dos moradores é coletado regularmente pela prefeitura, com destino ao lixão da cidade. 


\section{CONSIDERAÇÕES FINAIS}

Ao longo de toda sua história, o Brasil sempre apresentou problemas habitacionais e as políticas públicas não foram eficazes no que diz respeito a solucionar estas adversidades, que atinge principalmente a população mais carente.

A regularização fundiária, nesse aspecto, surge enquanto um elemento determinante para a modificação desta realidade, uma vez que é dever dela apontar projetos urbanísticos, quando necessários, obras de infraestrutura, soluções de drenagem e quaisquer outros meios para a melhoria do local a ser implementado o referido processo, não se restringindo apenas a titulação dos imóveis ou tributação dos mesmos.

Para Pau dos Ferros, que ainda não dispõe de um plano diretor, mas observa a questão da regularização fundiária como imprescindível para a garantia do direito à moradia digna, o processo proposto pelo Programa Acesso à Terra Urbanizada é de suma importância no contexto de contenção das problemáticas desse núcleo, conforme analisado com o auxílio dos gráficos.

\section{REFERÊNCIAS}

[1] AKAISHI, A. G. Desafios do planejamento urbano-habitacional em pequenos municípios brasileiros. Revista Risco, v. 14, n. 2, p. 41-50, 2011.

[2] BRASIL. Lei 13.465, de 11 de julho de 2017. Dispõe sobre a regularização fundiária rural e urbana, sobre a liquidação de créditos concedidos aos assentados da reforma agrária e sobre a regularização fundiária no âmbito da Amazônia Legal. Diário Oficial da União, Brasília, 2017.

[3] Ministério do Planejamento, Orçamento e Gestão. Regularização Fundiária. Brasília: MP, 2018. Disponível em: http://www.planejamento.gov.br/assuntos/gestao/patrimonio-da-uniao/destinacao-deimoveis/regularizacao-fundiaria 


\section{Capítulo 22}

\section{Estudo da compreensão dos mineradores sobre os planos de recuperação de áreas degradadas pela extração de calcário laminado}

\section{Letícia Lacerda Freire}

Mariell Lima Costa

Marcos Antonio Pereira da Silva

Lidiane Marinho Teixeira

Viviane Brito Viana

Resumo: Atividades de extração mineral exigem um Plano de Recuperação de Áreas Degradadas. Há princípios técnicos relacionados à execução deste plano que muitas vezes não chegam até os proprietários das áreas impactadas nem tão pouco aos mineradores. Logo neste estudo se quis compreender a visão destes e suas principais demandas e/ou impasses na fase de execução dos PRAD's. Trabalhou-se com representantes de uma cooperativa consolidada na região que possui licenciamento das áreas de extração. Dividiu-se a análise em cinco etapas que compreenderam desde o levantamento da realidade socioeconômica até questões mais específicas aos estudos ambientais e suas formas de execução, a partir de encontros e oficinas em campo, junto ao estudo dos planos elaborados pela consultoria ambiental contratada, além de estudo bibliográfico. Pôde-se constatar a necessidade de maiores esclarecimentos pelas consultorias contratadas e pelo órgão ambiental. Identificou-se que o orçamento de execução nas áreas é por volta de $\mathrm{R} \$ 28.000,00$. Entretanto os maiores custos são nas atividades iniciais, gerados pela necessidade de maquinário. Os demais custos como a compra de adubo e das mudas podem ser minimizados pela construção de viveiro e práticas de compostagem entre os integrantes da cooperativa. Identificou-se ainda necessidade de um sistema de gestão ambiental construído de forma participativa, para racionamento dos recursos necessários à atividade e à recuperação, principalmente quanto aos recursos hídricos. Em relação aos PRAD's apresentaram-se muito semelhantes, não abordando as peculiaridades e breve diagnóstico ambiental específico, mantiveram um valor de execução fixo apesar das diferenças encontradas em cada lavra de extração.

Palavras-chave: Mineração, PRAD, Entendimento, Gestão participativa. 


\section{INTRODUÇÃO}

São estabelecidos pela Instrução Normativa ICMBio No 11 de Dezembro de 2014, os procedimentos legais para “ (...) elaboração, análise, aprovação e acompanhamento da execução de Projeto de Recuperação de Área Degradada ou Perturbada - PRAD, para fins de cumprimento da legislação ambiental". Tal instrução define área degradada como aquela que possui dificuldade de restabelecer suas condições iniciais de forma natural, em razão ter sofrido algum impacto ambiental. Este caso é muito comum em regiões de extração mineral.

Na região do Cariri Cearense, em especial nos municípios de Santana do Cariri, Nova Olinda e Altaneira, uma das atividades econômicas que se destaca é a extração de calcário laminado, que tem importância na economia local, mas apresenta como consequência uma série de impactos ambientais inerentes à atividade e que por este motivo requer a recuperação da área.

Compreender a visão daquele que deve oferecer o estudo, mas que em geral, não é ele quem o elabora, em decorrência das necessidades de avaliação técnica, se apresenta como uma ferramenta de gestão ambiental participativa nos processos decisórios e na busca de melhoria para o manejo de zonas com atividades econômicas instaladas. É válido ressaltar que a dinâmica econômica é movida por fatores e demandas sociais, principalmente na ausência de oportunidades de capacitação o que influi na ocupação de cargos que exijam mão-de-obra especializada.

As áreas possuem proximidade, pois seguem os afloramentos da Bacia Sedimentar do Araripe e os mineradores se organizam em cooperativa, para favorecer a comercialização do material assim como os processos de licenciamento. Após a etapa de extração há várias camadas de rejeito sobrepostas, se alterou a formação topográfica, ocasionou-se o afugentamento da fauna assim como a supressão vegetal logo no início da abertura de lavra. Entretanto, na maioria das vezes não se executa o PRAD, sendo este solicitado pelo órgão ambiental e realizado por consultorias, contudo sem a participação efetiva dos mineradores envolvidos por diversos aspectos. Logo o presente estudo busca avaliar o nível de compreensão dos proprietários de minas em relação ao acompanhamento do estudo e a importância deste processo na execução de recuperação das áreas impactadas.

\section{METODOLOGIA}

\subsection{CARACTERIZAÇÃO DA ÁREA EM ESTUDO}

A área em estudo está localizada no município de Nova Olinda - Ceará, e o público trabalhado corresponde a 22 representantes das mineradoras de extração de calcário laminado, pertencentes a uma cooperativa consolidada na região. A figura 1 indica localização da região mineral do Cariri, segundo SOUZA, 2016, que permite identificar localização da mineração em Nova Olinda.

LEITE et al 2015, destaca importância da unidade Geoambiental da Chapada do Araripe para o Bioma Caatinga em razão dos valores de pluviosidade relativos ao que é registrado no Estado do Ceará e pela sua rica biodiversidade mantida pelas condições ambientais presentes em regiões subúmidas. 
Figura 1. Localização das áreas de Mineração da Região do Cariri.

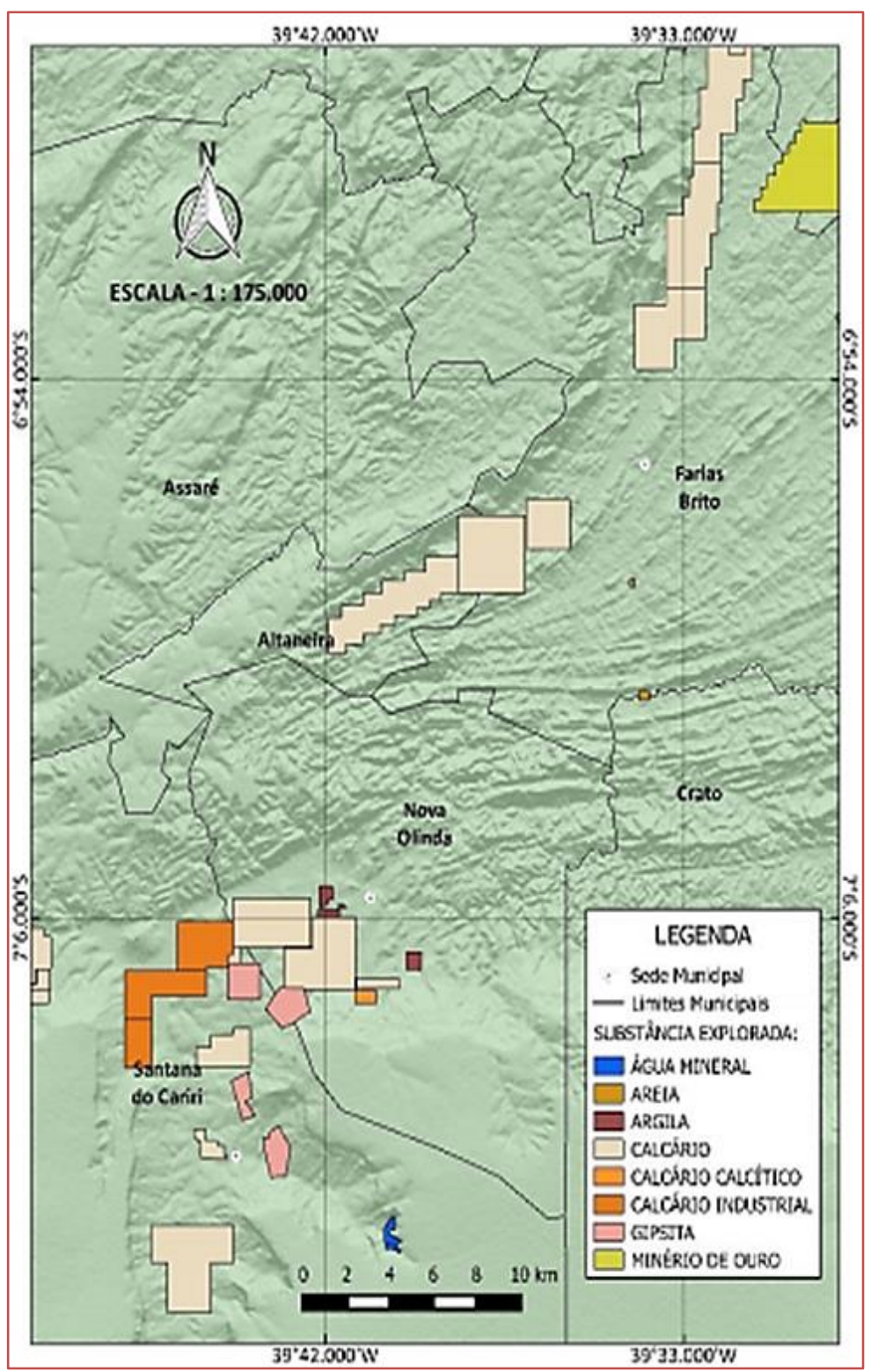

Fonte: SOUZA, 2016

\subsection{ETAPAS DE OBTENÇÃO DE DADOS}

O estudo foi realizado junto ao Projeto "Mais Palmas", desenvolvido pelo Time Enactus IFCE Juazeiro do Norte, na busca de melhorar a qualidade de vida dos mineradores, auxiliando no processo de recuperação das áreas. A pesquisa fundamentou-se em referencial bibliográfico e levantamentos em campo. Para obtenção dos dados a serem discutidos, determinou-se cinco etapas de levantamentos e atividades, pontuadas a seguir.

\section{Levantamento socioeconômico.}

O levantamento socioeconômico foi realizado a partir da aplicação de questionário semiestruturado para o recolhimento de depoimentos a fim de se construir uma visão ampla e discursiva em relação aos objetivos do estudo.

\section{Verificação das áreas que possuem o PRAD.}

Esta etapa baseou-se no levantamento e disponibilização dos PRAD’s existentes, para estudo e posterior explanação (definida como etapa 5). 


\section{Verificação dos mineradores que tinham conhecimento sobre material descrito no PRAD.}

Baseou-se também em depoimentos e na avaliação do estágio de execução do PRAD a partir de visitas nos locais a serem recuperados.

4. Momentos de esclarecimento e estudo sobre o PRAD, seu cronograma, orçamento e demais exigências.

No primeiro momento discutiu-se sobre a estrutura de organização dos PRAD's que foram disponibilizados pelos mesmos. No segundo discutiu-se sobre os critérios mais práticos de execução referentes aos tratos com a área - preparo do solo, plantio e manutenção. Em um terceiro momento realizou-se visita às áreas junto aos mineradores para que se fosse analisado com base no conversado nos encontros anteriores, os estágios de cada área e suas referidas demandas. Em último momento fez-se oficina de preparo do solo e plantio de mudas nativas como teste da atuação dele na manutenção para o desenvolvimento das espécies.

\section{Listagem das principais demandas no momento de execução.}

A partir do que foi documentado nas atividades anteriores, fez-se a lista, por ordem de prioridades das demandas no processo de execução do PRAD, quanto ao que depende da atuação dos proprietários da mina e de quem presta serviço na mesma.

\section{RESULTADOS E DISCUSSÃO}

\section{Levantamento socioeconômico.}

De acordo com a Secretaria de Desenvolvimento Local e Regional do Estado do Ceará as técnicas de extração do calcário laminado, conhecido popularmente como "Pedra Cariri" veio para a região pelo Sr. Antonio Felipe, no seu retorno de São Paulo, onde trabalhou na construção civil com rochas naturais oriundas do Rio Grande do Norte, Bahia e Minas Gerais. Este teve percepção da possibilidade de implantar o sistema em Nova Olinda, iniciando uma parceria com Assis Pereira, no ano de 1985.

A atividade extrativa mineral representa aproximadamente $6 \%$ das atividades econômicas municipais com a geração de 95 empregos formais, com predominância masculina na ocupação dos cargos, conforme apresentado na figura 01. Desconsiderando os dados de agropecuária, que não foram disponibilizados, esta é a quarta que mais possui empregos, ficando atrás apenas dos serviços de Administração Pública, Indústria de Transformação e Comércio. Em estudo da SEFAZ, publicado pelo IPECE (2015), a extração mineral representa ainda $12,5 \%$ das empresas industriais ativas de Nova Olinda. É importante indicar ainda que há uma considerável quantidade de empregos informais gerados.

Figura 02 . Empregos formais do Município de Nova Olinda e no Estado do Ceará no ano de 2014.

\begin{tabular}{|c|c|c|c|c|c|c|}
\hline \multirow{3}{*}{ Discriminaçao } & \multicolumn{6}{|c|}{ Número de empregos formais } \\
\hline & \multicolumn{3}{|c|}{ Municipio } & \multicolumn{3}{|c|}{ Estado } \\
\hline & Total & Masculino & Feminino & Total & Masculino & Feminino \\
\hline Total das Atividades & 1.618 & 883 & 735 & 1.552 .447 & 870.979 & 681.468 \\
\hline Extrativa Mineral & 95 & 88 & 7 & 3.336 & 3.034 & 302 \\
\hline Indüstria de Transtormaçఎo & 307 & 301 & 6 & 264.640 & 162.810 & 101.830 \\
\hline Senvicos Industriais de Utilidade Pública & • & $\therefore$ & : & 8.974 & 7.435 & 1.539 \\
\hline Construģa Civil & 17 & 16 & 1 & 92.801 & 85.779 & 7.022 \\
\hline Comercio & 206 & 135 & 71 & 274.168 & 160.615 & 113.553 \\
\hline Senvigos & 58 & 41 & 17 & 489.854 & 275.286 & 214.568 \\
\hline Administraçao Pública & 935 & 302 & 633 & 391.925 & 152.560 & 239.365 \\
\hline Agropecuária & • & - & • & 26.749 & 23.460 & 3.289 \\
\hline
\end{tabular}

Fonte: Ministério do Trabalho apud IPECE (2015)

A área é apontada ainda como um polo importante de achados paleontológicos e para a promoção do turismo local; quando se é trabalhado educação geoambiental nas áreas de extração. Em nota publicada pelo Diário do Nordeste (2012), sobre Projeto "Jovens Paleontólogos", o então coordenador, professor Idalécio Freitas afirma "O importante é educar os mineradores para que os fósseis permaneçam no Cariri. Assim, asseguramos novas pesquisas de espécies ainda não catalogadas. Queremos também despertar a população para a geoconservação no território do Geopark Araripe." A passagem ressalta a importância de se desenvolver trabalhos junto aos mineradores. 
Dos entrevistados o que tinha menor tempo de serviço estava há um pouco mais de um ano na atividade e o que tinha maior tempo estava há mais de dezesseis anos. 0 questionário sócioeconômico revelou que o lucro dos mineradores é muito baixo, baseando-se na produção, sendo equivalente a uma média de $\mathrm{R} \$ 2,00$ por metro quadrado extraído. Tal valor apresentou quedas com a crise.

As taxas de escolarização do município (87,58\%) divulgadas pelo IPECE (2015) apresentaram-se superiores à média estadual (83,82\%), isto condiz com um dos dados levantados; pois os mineradores que tinham filhos relataram que estes possuem acesso à educação escolar.

Quanto ao acesso ao saneamento houve dificuldades de fornecer informações, no entanto mais de $50 \%$ dos entrevistados relataram possuir fossa séptica.

\section{Verificação das áreas que possuem PRAD}

Todos os 22 mineradores que compunham a Cooperativa possuem o PRAD desde o ano de 2014, um deles um pouco diferenciado em decorrência de se remeter a recuperação de área desmatada e não ainda minerada visto que esta não possuía ainda a licença para início das atividades.

\section{Verificação dos mineradores que tinham conhecimento sobre material descrito no PRAD.}

Os 22 analisados tinham visto o estudo no momento em que receberam da consultoria contratada, entretanto depois não fizeram uso do material. Apenas quatro deles estavam em estágio médio de execução, com o nivelamento topográfico e a colocação das primeiras camadas de solo; para posterior melhoramento e plantio das espécies nativas indicadas.

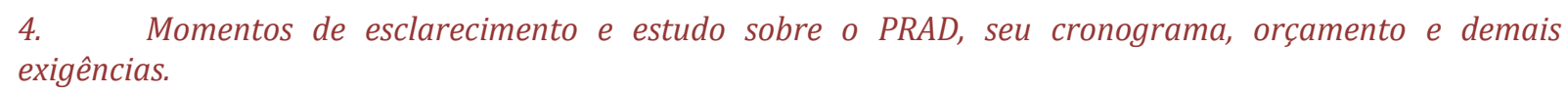

Inicialmente realizou-se momentos discursivos sobre os Planos de Recuperação de Áreas Degradadas, assim como seu cronograma, orçamento e demais exigências e formas de execução, com base nos PRAD's disponibilizados pelos mineradores. Apesar destes terem analisado o estudo no momento em que receberam da consultoria, foi possível observar que os mesmos possuíam pouca familiaridade com o PRAD e apresentaram dúvidas sobre a execução e suas exigências. Entretanto mostraram interesse no processo de aprendizagem e reconheceram a necessidade de dar continuidade às atividades em decorrência da possibilidade de multas dos órgãos públicos e da situação em que se encontram as áreas.

Quanto ao orçamento o valor médio presente em todos os estudos foi em torno de $\mathrm{R} \$ 28.000,00$, considerado por muitos um valor superior ao necessário o que representa um impasse de execução. Além disso, apontaram que havia formas mais práticas de aquisição das ferramentas e materiais necessários, como no caso do esterco e mudas, e a problemática maior estaria na aquisição do maquinário operacional e na água para manter o crescimento das mudas, visto que a região enfrenta a falta de chuva, sendo abastecidos com caminhões pipa que cobram um valor de $\mathrm{R} \$ 120,00$ a $\mathrm{R} \$ 150,00$.

No que diz respeito às etapas de execução apresentaram reconhecimento e dúvidas na concomitância entre a recuperação e a continuidade da atividade, ressaltando que as lavras são sequenciais e "não haveria viabilidade de fechar uma lavra para recuperação se a seguinte estava atrás da mesma" (depoimento de um dos participantes do estudo). Esta informação torna claro que deve transparecer no Estudo o período de implantação e o manejo adequado da camada de rejeitos e de solo, logo no início da abertura de lavra, criando zonas de espera do material, próximo à área a ser recuperada; minimizando a perda de espaço útil ou até mesmo do próprio material.

A visita às áreas para revisão dos conceitos trabalhados e das pontuações feitas nos momentos anteriores foi fundamental para a abertura de discussão e o transparecer das demandas. É importante mencionar que todos os PRAD's eram muito semelhantes e possuíam as mesmas indicações, entretanto cada área tinha suas características próprias e se encontravam em estágios distintos de regeneração. Logo necessitavam também de tratos distintos.

A oficina de plantio de mudas e manejo do solo foi desenvolvida apenas em três das quatro áreas que já haviam realizado a reposição topográfica. 0 interesse em colaborar foi bastante evidente, principalmente pela percepção da simplicidade de execução dos métodos propostos pela literatura em processos de recuperação. 
5. Listagem das principais demandas no momento de execução.

1. 1. Acompanhamento instrutivo e prático da execução do PRAD.

2. Compreensão básica sobre as ferramentas do processo de gestão ambiental.

3. Reconhecimento de metodologias para melhor utilização dos recursos hídricos, necessários para manter a atividade e a recuperação da área no estágio inicial de crescimento das espécies.

4. Implantação de Sistema de Gestão Ambiental, no qual, dentre outras definições, deve constar a indicação de local de espera para rejeitos e solo de cada área que futuramente será recuperada.

\section{CONCLUSÕES}

A atuação dos mineradores durante o estudo foi construtiva e participativa. Conclui-se que há dificuldades quanto a instruções técnicas na execução do PRAD, necessitando de maiores esclarecimentos pelas consultorias contratadas e pelo órgão ambiental. A parte mais onerosa observada pelas discussões sobre os estudos é evidenciada na fase inicial, pelo uso do maquinário para reposição topográfica. Entretanto nas etapas posteriores pode haver abatimento de custos caso haja banco de mudas na região e sistemas de produção de adubo orgânico o que é sugerido como investimento para a própria cooperativa em relação a demandas atuais e futuras. Uma das grandes problemáticas atuais identificadas está relacionada com a falta de água para manter o crescimento das mudas, tendo em vista que a região vem sofrendo com a escassez hídrica, intensificada pelo período de estiagem, sendo necessário o uso de caminhão pipa para o abastecimento.

\section{REFERÊNCIAS}

SOUZA, E.L. IMPACTOS AMBIENTAIS NA MINERAÇÃO DE CALCÁRIO LAMINADO EM NOVA OLINDA-CE. Trabalho de Monografia do Bacharelado em Engenharia Ambiental pelo Instituto Federal de Educação Ciência e Tecnologia do Ceará, 2016.

BRASIL. Instrução Normativa ICMBIO Nº 11 de 11 de Dezembro de 2014. Instituto Chico Mendes Para a Conservação da Biodiversidade, 2014.

CEARÁ. ARRANJO PRODUTIVO LOCAL DE PEDRAS ORNAMENTAIS EM NOVA OLINDA E SANTANA DO CARIRI. Secretaria de Desenvolvimento Local e Regional do Governo do Estado do Ceará.

LEITE, R.F.C; FREIRE, L.L; MOREIRA, D.A; NETO,B.S. Análise da Interferência dos fatores climáticos nas Unidades Geoambientais Sub-Úmidas do Ceará (Chapada do Araripe e Serra da Ibiapaba). XIX Congresso Brasileiro de Agrometeorologia, 2015. 


\section{Capítulo 23}

\section{Análise da qualidade da água do açude Epitácio Pessoa no município de Boqueirão - PB}

\section{Julyanna Damasceno Pessoa \\ Bruna da Silveira Guimarães \\ Josevania Rodrigues Jovelino}

Kamila Freitas Porto

Kepler Borges França

Resumo:Em decorrência da degradação dos recursos hídricos e da crescente preocupação com microrganismos específicos na água, a utilização de membranas cerâmicas para separação de materiais contaminantes, passa a ser uma opção de tratamento para a produção de água potável, devido a motivos como, por exemplo, sua resistência ao ataque de produtos químicos, requerer uma menor área de construção do equipamento, maior economia de energia, dentre outros. 0 presente trabalho objetivou estudar o desempenho de um sistema composto por membrana cerâmica tubular de microfiltração para tratamento de água de qualidade inferior. As membranas utilizadas nesse trabalho são do tipo $\alpha$-alumina ( $\alpha$-Al203), tamanho nominal de poro de aproximadamente $0,8 \mu \mathrm{m}$, produzidas pelo Laboratório de Membranas Cerâmicas (LABCEM) do Laboratório de Referência em Dessalinização (LABDES) na Universidade Federal de Campina Grande (UFCG). 0 sistema foi avaliado em teste de presença / ausência e contagem bacteriológicas na água da alimentação e permeado para o sistema nas pressões de operação 0,5; 1,0; 2,0 e 3,0 bar no sistema de membrana cerâmica. A membrana cerâmica removeu completamente os Coliformes totais e fecais (Escherichia coli) da água. 0 sistema híbrido mostrou-se eficiente na remoção de microrganismos e produziu água tratada de boa qualidade quanto aos parâmetros bacteriológicos nas águas de qualidade inferior, com baixo consumo energético.

Palavras-chave: Membrana cerâmica. Microfiltração. Escherichia coli. Coliformes Totais. 


\section{1 - INTRODUÇÃO}

A água subterrânea é considerada uma fonte imprescindível de abastecimento para o consumo humano, principalmente para populações que não têm acesso à rede pública de abastecimento ou mesmo para aqueles que tendo acesso, têm o fornecimento irregular. Suas fontes de contaminação estão, em geral, associadas a despejos domésticos, industriais e ao chorume oriundo de aterros de resíduos sólidos, que quando dispostos de forma inadequada podem poluir e contaminar os lençóis freáticos com microrganismos patogênicos (FREITAS et al., 2001).

A Portaria № 2.914, de 12 de dezembro de 2011 do Ministério da Saúde estabelece que sejam determinados, na água, para aferição de sua potabilidade, a presença de coliformes totais e termotolerantes de preferência Escherichia coli e a contagem de bactérias heterotróficas. A mesma portaria recomenda que a contagem padrão de bactérias não deve exceder a $500 \mathrm{UFC} / \mathrm{mL}$ de amostra, tal como não tolerar em nenhuma amostra de água tratada a presença de coliformes termotolerantes e admitir a presença de coliformes totais em algumas situações no sistema de distribuição.

Estudos foram realizados por Bottino et al. (2001), com membrana cerâmica 0,2 nm, nos quais foram avaliados a remoção de partículas, microrganismos, algas e precursores dos produtos de desinfecção. A remoção de coliformes totais e fecais foi de $100 \%$ e para a maioria das algas estudadas a remoção foi total.

0 objetivo deste trabalho foi analisar a qualidade do permeado em termos bacteriológicos, no desempenho da membrana cerâmica sem resina.

\section{2 - MATERIAIS E MÉTODOS}

O Sistema abaixo apresenta uma alimentação com água sintética internamente no início da membrana cerâmica A saída do concentrado se encontra no final da membrana cerâmica no lado oposto, induzindo a água percorrer toda a membrana de forma tangencial provocando o arraste das partículas próximas a superfície interna da membrana. As correntes do concentrado e permeado voltam ao taque de alimentação como mostra a Figura 1. Análises como contagem bacteriológica e presença/ausência de bactérias foram feitas no permeado obtido depois de duas horas de permeação.

Figura 1 - Tratamento de água com membrana cerâmica

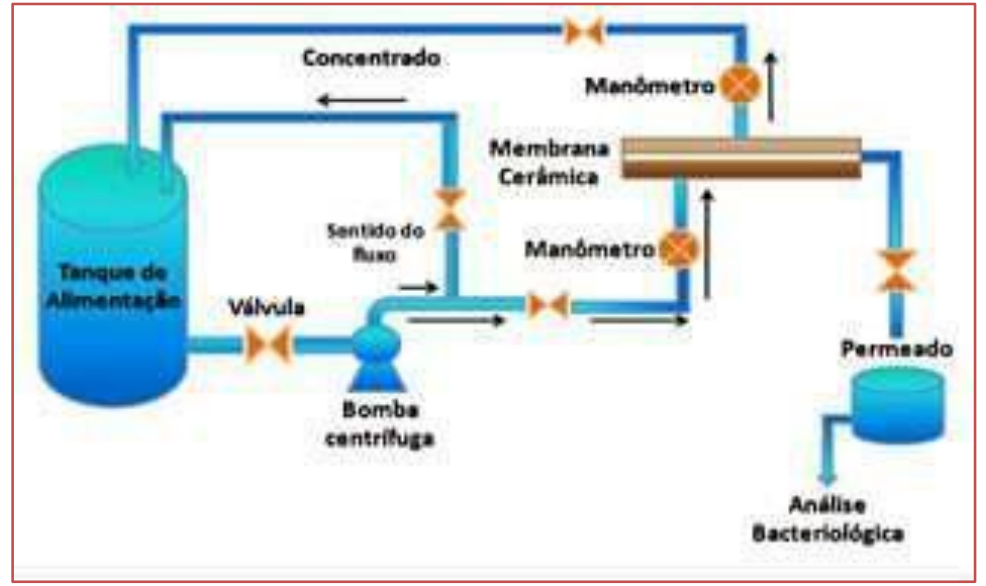

Fonte: Autora (2019) 
A limpeza química da membrana foi realizada da seguinte forma: as membranas ficaram imersas durante $24 \mathrm{~h}$ em uma solução de $\mathrm{NaOH}(\mathrm{pH}=10)$; em seguida, foram lavadas com água deionizada para remover todo $\mathrm{NaOH}$; após, foram imersas por $24 \mathrm{~h}$ em uma solução de $\mathrm{HCl}(\mathrm{pH}=3)$; por fim, foram lavadas com água deionizada para remover todo $\mathrm{HCl}$; as membranas foram colocadas em estufa por mais ou menos $1 \mathrm{~h}$ a $60^{\circ} \mathrm{C}$.

\section{3 - RESULTADOS E DISCUSSÕES}

As Tabelas 1 e 2 estão apresentam valores referentes às análises quantitativas das bactérias do grupo coliforme: Coliformes Totais e Escherichia coli, respectivamente.

Tabela 1 - Análise Bacteriológica Quantitativa e Qualitativa de Coliformes Totais realizadas em duplicata para a água sintética da alimentação e do permeado.

\begin{tabular}{|c|c|c|}
\hline \multicolumn{3}{|c|}{ Coliformes Totais } \\
P (bar) & Alimentação & Permeado \\
\hline 0,5 & $0,372 \times 103$ & 0 \\
\hline 1 & $0,914 \times 103$ & 0 \\
\hline 2 & $0,235 \times 103$ & 0 \\
\hline 3 & $0,043 \times 103$ & 0 \\
\hline
\end{tabular}

Tabela 2 - Análise Bacteriológica Quantitativa e Qualitativa de Escherichia coli realizadas em duplicata para a água sintética da alimentação e do permeado.

\begin{tabular}{|c|c|c|}
\hline & \multicolumn{2}{c|}{ Escherichia coli } \\
$\mathrm{P}(\mathrm{bar})$ & Alimentação & Permeado \\
\hline 0,5 & $0,245 \times 103$ & 0 \\
\hline 1 & $0,198 \times 103$ & 0 \\
\hline 2 & $0,063 \times 103$ & 0 \\
\hline 3 & $0,031 \times 103$ & 0 \\
\hline
\end{tabular}

Quanto maior o índice de presença de coliformes, mais a água (ou o alimento), estão contaminados, logo se observa nas Tabelas 1 e 2 a remoção completa dos Coliformes Totais e Escherichia coli. Observa-se que uma membrana cerâmica de microfiltração pode ser utilizada para descontaminar águas contendo bactérias nocivas à saúde, tornando-as dentro dos padrões de potabilidade previstos pela PORTARIA № 2.914, de 12 de dezembro de 2011 do Ministério da Saúde.

\section{4 - CONCLUSÃO}

O sistema híbrido apresentou ótima eficiência em relação à remoção dos parâmetros bacteriológicos da água, tornando-a apta a reutilização e até ao consumo, removendo completamente bactérias nocivas à saúde humana, como Escherichia coli e as bactérias do grupo Coliformes Totais.

\section{REFERÊNCIAS}

[1] FREITAS, M. B.; BRILHANTE, O. M.; ALMEIDA, L. M. Importância da análise de água para a saúde pública em duas regiões do estado do Rio de Janeiro: enfoque para coliformes fecais, nitrato e alumínio. Cad. Saúde Pública, Rio de Janeiro, v.17, p. 651-660, 2001.

[2] BOTTINO, A.; CAPANNELli, C.; DEL BORGHI, A. Water treatment for drinking purpose: ceramic microfiltration application, Desalination, v. 141, p. 75-79, 2001. 


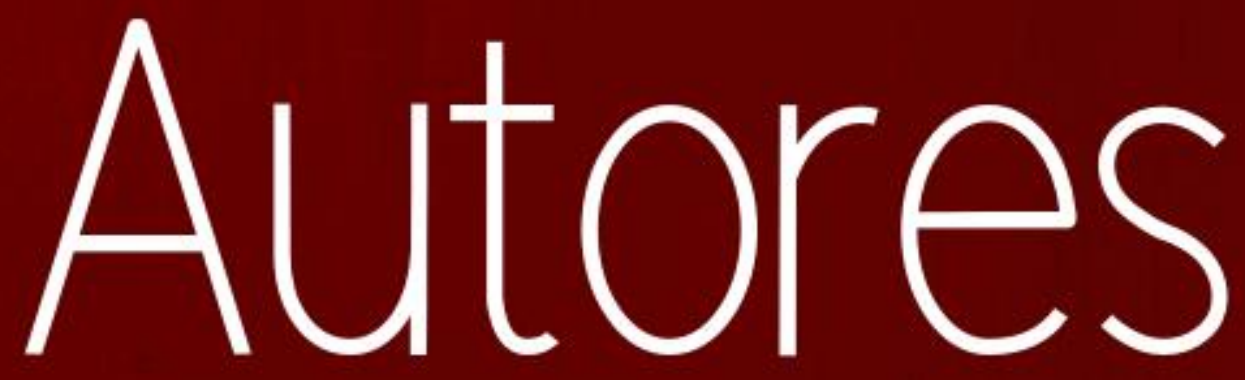




\section{ADAUTO NETO FONSECA DUQUE}

Professor na Universidade Estadual do Piauí (UESPI). Graduado em História pela Universidade Federal do Amazonas (UFAM); Mestre em História Social pela Universidade Federal do Ceará (UFC). Tem experiência na área de docência com ênfase na formação de professores e pedagogos. Atua como pesquisador sobre diversidade étnica e cultural, quilombos na contemporaneidade, tradição, saberes, oralidade e escravidão. Desenvolve pesquisa sobre história e memória em comunidades negras ruais no semiárido piauiense.

\section{ADIEL FELIPE DA SILVA CRUZ}

Mestre em Engenharia Agrícola pela Universidade Federal Rural de Pernambuco com principal atuação nas relações hídricas, características morfofisiológicas e produtivas em hidroponia sob salinidade, manejo de irrigação fertirrigação e aproveitamento de resíduos agropecuários (2017). Engenheiro Agrônomo pela Universidade Federal Rural de Pernambuco (UFRPE) (2016). Técnico em Agropecuária pela Fundação Bradesco unidade Garanhuns-PE (2008).

\section{AILMA ROBERIA SOUTO DE MEDEIROS}

Possui graduação em Engenharia de Minas pela Universidade Federal de Campina Grande - UFCG, Mestrado em Engenharia Mineral pela Universidade Federal de Pernambuco UFPE e atualmente é Doutoranda em Engenharia de Processos pela Universidade Federal de Campina Grande - UFCG. Desde de 2013 é professora do Curso Técnico em Mineração do Instituto Federal da Paraíba - IFPB/Campus Picuí e Líder do Grupo de Pesquisa do CNPq "Estudos em Mineração no Semiárido".

\section{AISSA ROMINA SILVA DO NASCIMENTO}

Bacharelado em Ciências Sociais pela Universidade Federal da Paraíba (2001) Doutorado em Sociologia pela Universidade Federal da Paraíba (2014), Mestrado em Sociologia pela Universidade Federal da Paraíba (2003) e Especialização em Planejamento e Gestão em Ensino-Aprendizagem pelo Centro Universtário de João Pessoa (2005). Atualmente é professora da Universidade Federal de Campina Grande do Centro de Formação de Professores na Unidade Acadêmica de EnfermagemUFCG/CFP/UAENF

\section{ALEKSSANDRO SOUSA LIBÉRIO}

Mestrando em Direito Constitucional. Especialista em Direito Penal e processo Penal. Especialista em Educação a distância. Bacharel em Direito pela UESPI. Advogado.

\section{ALMIR MARIANO DE SOUSA JÚNIOR}

Possui graduação em Engenharia de Produção pela Universidade Federal Rural do SemiÁrido, Especialista em Engenharia de Segurança do Trabalho, Especialista em Geografia e Gestão Ambiental, Mestrado em Engenharia de Petróleo e Gás Natural e Doutor em Ciência e Engenharia de Petróleo (UFRN). Atualmente é professor Efetivo da Universidade Federal Rural do Semi-Árido, professor do Mestrado Acadêmico em Planejamento e Dinâmicas Territoriais da Universidade Estadual do Rio Grande do Norte, Diretor Administrativo da Caixa de Assistência aos Profissionais do CREA-RN e Pró-Reitor Adjunto de Extensão e Cultura da UFERSA. Atualmente desenvolve pesquisas e extensão universitária na área de Planejamento Urbano, Cidades Inteligentes e Regularização Fundiária Urbana. 


\section{ANA KATARINA PESSOA DE OLIVEIRA}

Docente Associada da Universidade de Saragoça/Espanha. Doutora em Contabilidade e Finanças na Universidade de Saragoça/Espanha (2016). Mestre em Contabilidade e Finanças pela Universidade de Saragoça/Espanha (2009). Mestre em Administração de Empresas pela UFRN (2006). Especialista em Contabilidade Gerencial pela UFRN (2004). Especialista em Gestão de Iniciativas Sociais pela UFRJ (2003). Graduada em Ciencias Contabeis pela UFRN (1997). Atualmente é membro do grupo de pesquisa certificado pelo CNPq da Universidade Federal da Paraíba (CCSA + CEAR) em Ecoeficiência e Gestão empresarial, membro do projeto de pesquisa com mesmo nome, além de coordenadora do projeto de pesquisa sobre Análisis de solvencia de las empresas, na Universidade de Zaragoza (Espanha).

\section{ANDERSON SANTOS DA SILVA}

Engenheiro Agrônomo pela Universidade Federal Rural de Pernambuco (2009). Técnico em Agrícola pela Escola Agrotécnica Federal de Vitória de Santo Antão - PE (2001). Possuí o Mestrado em Engenharia Agrícola com ênfase em Irrigação e Drenagem pela Universidade Federal de Campina Grande (UFCG) no ano de 2012. Doutor na área de Engenharia Agrícola (Água no solo) pela Universidade Federal Rural de Pernambuco em 2016. Atualmente é Professor Adjunto da Universidade Federal Rural de Pernambuco na Unidade Acadêmica de Garanhuns nas disciplinas de Topografia, Cartografia e Geoprocessamento.

\section{ANDERSON SILVA PINTO}

Doutorando em Etnobiologia e Conservação da Natureza pela Universidade Federal Rural de Pernambuco

\section{ANIZIO HONORATO GODOI NETO}

Engenheiro Agrônomo pela Universidade Federal Rural de Pernambuco (UFRPE) (2015). Tem experiência na área de Agronomia, com ênfase em Irrigação, atuando principalmente nos seguintes temas: manejo da irrigação em culturas anuais/semi-perenes, hidráulica de sistemas de irrigação, fertirrigação. Atualmente realiza o curso de MBA em Gestão do Agronegócio na Escola Superior de Agricultura Luiz de Queiroz, ESALQ, Brasil

\section{ANTONIO RICARDO SANTOS DE ANDRADE}

Graduado em Meteorologia pela Universidade Federal da Paraíba (1994 - UFPB), graduação em Matemática pela Universidade Federal do Rio Grande do Norte (2013 UFNR), mestrado em Engenharia Agrícola pela Universidade Federal da Paraíba (1997 UFPB), Mestrado em Matemática e Estatística pela Universidade Federal de Lavras (2005 - UFLA) e doutorado em Agronomia (Irrigação e Drenagem) pela Universidade Estadual Paulista Júlio de Mesquita Filho (2002 - UNESP). Professor adjunto da Universidade Federal Rural de Pernambuco na Unidade Acadêmica de Garanhuns, atuando em ensino de graduação, pós-graduação (Saúde Pública na UPE) e pesquisa em temas relacionados a Estatística e Bioestatística aplicada, Experimentação e Multivariada Agrícola. Tem experiência na área de Engenharia Agrícola e Agrometeorologia, com ênfase em Física dos Solos, irrigação, variabilidade espacial. Tem experiência na área de Estatística e Bioestatística Aplicada, com ênfase em Estatística Experimental, Análise de Regressão e Análise Multivariada, atuando principalmente nos seguintes temas: Planejamento e Análise de experimentos, Geoestatística e Geometria fractal no estudo das propriedades dos solos. 


\section{BRENNA HORTINS DE OLIVEIRA}

Graduanda em Biologia pela Universidade Estadual da Paraíba

\section{BRUNA DA SILVA GOMES}

Técnica em Bicombustíveis pelo IFBA (2016). Graduanda em Administração pela Universidade do Estado da Bahia, UNEB-Campus XVI, onde foi bolsista de extensão e Diretora Presidente da Empresa Júnior, doravante denominada CONSOL- Consultoria e Soluções Organizacionais (2016-2017). Atualmente é Pesquisadora de Iniciação Científica, possuindo trabalhos publicados em âmbito nacional, especialmente na área de Gestão Ambiental do Semiárido.

\section{BRUNA DA SILVEIRA GUIMARÃES}

Graduada em Engenharia Química pela Universidade Federal de Campina Grande (2011). Mestrado em Engenharia Química, pela Universidade Federal de Campina Grande (2016). Doutorado em Engenharia Química (em andamento), pela Universidade Federal de Campina Grande na mesma área.

\section{BRUNA LARA BORGES DA SILVA}

Nascida em 23 de junho de 1994 em Oeiras (PI), viveu e cresceu com sua família na comunidade Furta-lhe a Volta, município de Ipiranga do Piauí, Piauí, onde concluiu seu Ensino Médio. Ingressou no Curso de Licenciatura em Educação do Campo/Ciências da Natureza ofertado pela Universidade Federal do Piauí no ano de 2014, graduando-se no ano de 2019. Durante a graduação atuou como bolsista do Programa Institucional de Bolsa de Iniciação à Docência (PIBID Diversidade) e, hoje, ocupa o cargo de Diretora na Escola Municipal Monsenhor Lopes, localizada no Povoado Forte, município de Inhuma, Piauí. Sempre lutou pelos direitos dos povos do campo e uma educação de qualidade para eles... Resistência sempre!!!

\section{CAIO TÁCITO MIRANDA CASTRO BEZERRA DE MELO}

Graduado em Engenharia Mecânica pela Universidade Federal de Campina Grande - UFCG, Mestre em Engenharia Mecânica na área de Fenômenos de Transporte e Energia pela Universidade Federal de Campina Grande - UFCG e Pós-Graduado em nível de especialização em Engenharia de Segurança do Trabalho pelas Faculdades Integradas de Patos - FIP. Atualmente é estudante em nível de Doutorado em Engenharia Mecânica na área de Termofluidos pela Universidade Federal da Paraíba - UFPB e atua atualmente como docente no Instituto Federal de Ciências e Tecnologia da Paraíba - IFPB

\section{CHRISTIANE FERNANDES DOS SANTOS}

Aluna do Doutorado em Desenvolvimento e Meio Ambiente, da Universidade Federal do Rio Grande do Norte (UFRN).Possui mestrado em Ambiente, Tecnologia e Sociedade, pela Universidade Federal Rural do Semi-Árido (2013); Especialização em Educação pela Universidade do Estado do Rio Grande do Norte (2010) e Licenciatura em Geografia pela Universidade do Estado do Rio Grande do Norte (2008). Pesquisadora do Laboratório de Estudos Rurais (LabRural/UFRN); Atualmente é técnica em assuntos educacionais da Universidade Federal Rural do Semi-Árido, e Vice-coordenadora do programa de extensão Semiárido Digital - UFERSA. 


\section{CHRISTIANNE TORRES DE PAIVA}

Engenheira Florestal (UFRPE), Mestre em Agronomia (UFRPE) e Doutora em Geociências (UFPE). Tem experiência na área de Meio Ambiente, com ênfase em Agrossilvicultura, Geoquímica de Solos, Manejo e Conservação de Solos, Recuperação de Áreas Degradadas, Licenciamento Ambiental e ainda na elaboração de Estudos Ambientais e de Projetos de Reposição/Compensação Florestal. Também possui experiência docente em nível médio/técnico/tecnológico, graduação e pós-graduação (MBA e Mestrado). Atualmente, é docente do Instituto Federal de Educação, Ciência e Tecnologia do Estado de Pernambuco - Campus Vitória de Santo Antão.

\section{CÍCERO DE FRANÇA NETO}

Graduando em Arquitetura e Urbanismo pela Universidade Federal Rural do Semi-Árido. Pesquisador no grupo de Pesquisa e Extensão Acesso à Terra Urbanizada de 2016 até atualmente.

\section{CLAUDIMEIRE LIMA DE SOUSA}

Especialista em Gestão de Recursos Ambientais no Semiárido pelo Instituto Federal do Piauí, campus Valença - PI (2018). Graduada em Química pelo Instituto Federal do Piauí, campus Picos - PI (2014), com experiência na área de Química Ambiental com ênfase em Resíduos Sólidos e Recursos Hídricos. Possui também Bacharelado em Administração Pública pela Universidade Federal do Piauí, campus Picos - PI (2013), com experiência na área de Gestão de Pessoas com ênfase em QVT / Ergonomia.

\section{CLAUDIO ROBERTO MEIRA DE OIIVEIRA}

Possui graduação em Engenharia Agronômica pela Universidade Estadual do Sudoeste da Bahia (1999), mestrado em Agronomia (Fisiologia Vegetal) pela Universidade Federal de Lavras (2002) e doutorado em Biologia Vegetal (Botânica) pela Universidade Federal de Viçosa (2009). Atualmente é professor adjunto da Universidade do Estado da Bahia. Tem experiência na área de botânica, com ênfase em ecofisiologia vegetal e fisiologia de sementes da Caatinga. Desenvolve projetos de educação ambiental com os seguintes temas: processos fisiológicos e reprodutivos de espécies nativas, germinação de sementes nativas, agrossilvicultura, plantios consorciados, poluição ambiental e saneamento básico associados ao ensino, a pesquisa e a extensão.

\section{D’ÁVILLA RUAMA FERNANDES LOPES GOMES}

Possui Graduação em Ciências Biológicas (Licenciatura) pela Universidade Estadual da Paraíba (2016). Mestre em em Ecologia e Conservação (PPGEC - UEPB) (2019) e estagiária no Laboratório de Ecologia \& Conservação de Florestas Neotropicais Secas (EcoTropics). Desenvolve trabalhos relacionados à Ecologia Vegetal

\section{DAISY CAROLINE NASCIMENTO PEREIRA}

Economista, mestre em economia (UFRN) e doutoranda em economia (UFU)

\section{DANIEL DE PAULA DINIZ}

Mestrando em Engenharia de Energias Renováveis no CEAR - Centro de Energias Alternativas e Renováveis da UFPB - Universidade Federal da Paraíba em João Pessoa, Paraíba, Brasil. Formado em Engenharia de Alimentos pela USFC - Universidade Federal 
de Santa Catarina. Linha de pesquisa: Processos Térmicos na Indústria Alimentícia no setor de Cervejarias, Análise de Ciclo de Vida e Pegada de Carbono.

\section{DANIELLE CASILLO}

Possui graduação em Engenharia de Computação pela Universidade Potiguar (2001), mestrado (2004) e doutorado (2009) na área de Automação e Controle em Engenharia Elétrica e de Computação pela Universidade Federal do Rio Grande do Norte. Atualmente é professora Associada I do Curso de Ciência da Computação do Centro de Ciências Exatas e Naturais da Universidade Federal Rural do Semiárido - UFERSA. Tem experiência na área de Engenharia Elétrica, com ênfase em Controle e Automação de Processos.

\section{EDMILSON FERREIRA DOS SANTOS}

Mestre em Linguística pela Universidade Federal da Paraíba (UFPB). Possui graduação em Letras - Português/Inglês - pela Universidade Federal de Pernambuco (2008). E graduação em Francês pela Universidade Federal de Pernambuco (2010). Professor substituto do departamento de Letras da Universidade Estadual do Piauí (UESPI) desde 2017 e do Instituto Federal de Educação, Ciência e Tecnologia (IFPE) desde março de 2019.

\section{EDUARDO AUGUSTO DA SILVA DINIZ}

Mestrando do Programa de Pós-Graduação em Química da Universidade Federal do Rio Grande do Norte (UFRN). Possui graduação em Engenharia Química pela Universidade Federal da Paraíba (jun/2017). Foi um dos membros fundadores da empresa júnior de Engenharia Química da UFPB (PROJEQ). Atualmente desenvolve pesquisa na área de simulação molecular aplicado a proteínas, com foco em proteínas quiméricas com efeito alostérico.

\section{EMANUEL JHONATA GOMES DA SILVEIRA}

Economista, mestre em economia (UFS)

\section{ERIVALDO LAURENTINO DA SILVA}

Engenheiro Agrônomo pela Universidade Federal Rural de Pernambuco - UFRPE, Unidade Acadêmica de Garanhuns - UAG. Atualmente é Mestrando no Programa de Pós-graduação em Fitopatologia na UFRPE. Atuou em Educação do Campo e projetos sociais (ProJovem Campo-Saberes da Terra). Desenvolve trabalhos na área de Fitopatologia em estudos envolvendo Controle Químico de Doenças de Plantas, com ênfase em Efeito Hormese de Fungicidas em Fungos Fitopatogênicos.

\section{EVANDRO ALBERTO DE SOUSA}

Doutor em serviço social pela Universidade Federal de Pernambuco- UFP. Mestre em serviço social também pela Universidade Federal de Pernambuco-UFPE. É especialista em comunicação educacional pela Universidade Estadual da Paraíba - É graduado em comunicação social (habilitação em jornalismo) pela Universidade Estadual da Paraíba. É professor efetivo (adjunto I - DE). Atualmente exerce o cargo de vice-reitor da Universidade Estadual do Piauí. 


\section{FABRÍCIO CORREIA DINIZ}

Possui graduação em Pedagogia pela Universidade Estadual Vale do Acaraú - UVA (2002) e Licenciatura e Bacharelado em Ciências Biológicas pela Universidade Estadual da Paraíba - UEPB (2004). Especialização em Educação Ambiental pela Universidade Estadual da Paraíba - UEPB (2006), Especialização em Fundamentos da Educação: práticas pedagógicas interdisciplinares pela Universidade Estadual da Paraíba - UEPB (2014) e Mestre em Ecologia e Conservação pela Universidade Estadual da Paraíba - UEPB (2016), com ênfase em comunidades vegetais ao longo de gradientes altitudinal e variáveis ambientais. Tem experiência na área de Educação como professor do Ensino Fundamental e Médio.

\section{FRANCISCO JOSÉ DOS SANTOS}

Possui Pós-Graduação Latu Senso em Gestão de Recursos Ambientais no Semiárido Pelo o Instituto Federal do Piauí-Campus Valença do Piauí (2018); Pós-Graduação Latu Senso em Ensino da Matemática e Estatística Aplicada pelo Instituto Superior de Educação Programus -ISEPRO (2018); Pós-Graduação Latu Senso em Docência do Ensino Superior pelo Instituto Superior de Educação Programus -ISEPRO (2017); Possui Graduação em Matemática pela Universidade Federal do Piauí (2016).; Está cursando Física - Instituto Federal do Piauí - Campus Oeiras-PI (Em Andamento); Atualmente é coordenador de polo do Instituto de Ensino Superior Silva Queiros Ltda - ME.

\section{GARDNER DE ANDRADE ARRAIS}

Professor Adjunto do Curso de Licenciatura em Educação do Campo/Ciências da Universidade Federal do Piauí - UFPI. É Doutor em Educação pelo Programa de PósGraduação em Educação da Universidade Estadual do Ceará - PPGE/UECE, Mestre em Educação também pelo PPGE/UECE e Especialista em Didática pela UECE. Graduado em Pedagogia pela UECE e também Licenciado em Arte e Educação pela Faculdade Integrada da Grande Fortaleza, atualmente, integra o grupo de pesquisa Investigação em Arte, Ensino e História - IARTEH/UECE.

\section{GENICLÉIA LISBOA ROLIM}

Enfermeira graduada pela UFCG; Licenciada em Letras Língua Vernácula e Língua Inglesa pela UFCG. Atualmente é enfermeira da Unidade Básica de Saúde Prefeito Doutorzinho.

\section{GILBEVAN RAMOS DE ALMEIDA}

Licenciado em Ciências Biológicas e Mestre em Ecologia e Conservação pela Universidade Estadual da Paraíba (PPGEC/UEPB). Atualmente é Doutorando em Ecologia e Conservação pela mesma instituição. Trabalha com Ecologia vegetal, com ênfase em fitossociologia, traços funcionais e diversidade funcional de comunidades arbustivasarbóreas da Caatinga.

\section{HERMÓGENES HENRIQUE OLIVEIRA NASCIMENTO}

Servidor Público e Gestor Ambiental. Ponto Focal do Cadastro Nacional de Unidades de Conservação - CNUC e da Estratégia e Plano de Ação Nacionais para a Biodiversidade EPANB da Secretaria do Meio Ambiente do Ceará - SEMA. Coordenador do Programa Agente Voluntário Ambiental, do Cadastro Estadual de Unidades de Conservação - CEUC e do Programa de Incentivo às Unidades de Conservação Municipais - ProUCm da SEMA. 
Graduado em Turismo pela Universidade Federal do Rio Grande do Norte - UFRN e PósGraduado em Gestão Ambiental, com ênfase no turismo sustentável, pelo Instituto Federal de Educação, Ciência e Tecnologia do Rio Grande do Norte - IFRN. Representante institucional titular como Conselheiro do Fórum Estadual de Turismo do Ceará. Tem experiência na área de consultoria em destinos turísticos sustentáveis. Gestor Ambiental da Célula de Conservação da Diversidade Biológica da SEMA. Pesquisador nas áreas de Ecoturismo, Governança Ambiental, Patrimônio Natural e Cultural, Planejamento Sistemático da Conservação (PSC), Uso Público e Tecnologia da Informação e Comunicação (TICs). Atua em Criação, Gestão e Efetividade de Unidades de Conservação, Sinalização, Voluntariado, Áreas Prioritárias para a Biodiversidade, Interpretação e Educação Ambiental e Trilhas Ecoturísticas. Membro Voluntário da Comissão Mundial de Áreas Protegidas (WCPA/IUCN), do Grupo de Especialistas em Turismo e Áreas Protegidas (TAPAS/WCPA/IUCN), do Grupo de Especialistas em Valores Espirituais e Culturais de Áreas Protegidas (CSVPA/WCPA/IUCN), do Grupo de Especialistas em Região Selvagem (WSG/WCPA/IUCN), do Grupo de Especialista de Conservação da Conectividade (CCSG/WCPA/IUCN), da Comissão de Política Ambiental, Econômica e Social (CEESP/IUCN), do Grupo de Especialista em Uso Sustentável e Meios de Subsistência (SSC/CEESP/IUCN), Membro do Programa de Gestão da Biodiversidade e Áreas Protegidas (BIOPAMA), Membro da Rede Global de Ecoturismo (GEN), Membro da Rede Aberta das Partes Interessadas da IPBES e Membro da Rede de Mosaicos de Áreas Protegidas (REMAP).

\section{HUGO LEONARDO PONTES NUNES}

Graduando em Arquitetura e Urbanismo pela Universidade Federal Rural do SemiÁridoUFERSA. Bolsista da AAMEG no projeto - Observatório das Ciências Sociais Aplicadas e Humanas entre os anos de 2016 e 2017. Pesquisador científico no grupo Laboratório de Estudos da Cidade, Urbanismo e Território - LaURBE, de 2016 a 2018. Atualmente pesquisador no grupo de Pesquisa e Extensão Acesso à Terra Urbanizada. Participação em Eventos Científicos com linha de pesquisa abordando o Sertão Nordestino, contendo enfoque em Urbanismo, Arquitetura e História.

\section{HUGO VIEIRA}

Possui Graduação em Agronomia pela Universidade Federal da Paraíba - UFPB (1997), Mestrado em Engenharia Agrícola pela Universidade Federal de Campina Grande - UFCG (2007) e Doutorando em Agronomia pela UFPB - CCA - Areia - PB. Atualmente é professor de Ensino Básico Técnico e Tecnologia do IFPB, Campus de Sousa - PB. Tem atuado nos seguintes temas: Agroecologia, manejo biodiversidade da caatinga, estudos fitossociológicos, controle da desertificação, agricultura familiar, manejo de raças nativas locais, resgate e cultivo de sementes crioulas locais.

\section{HUMBERTO ARAÚJO ALMEIDA}

Graduado do Curso de Licenciatura em Ciências Biológicas pela Universidade Estadual da Paraíba-UEPB. Mestrando em Biologia Vegetal pela Universidade Federal de Minas Gerais, é membro do Laboratório de Ecologia Vegetal - LEVe/UEPB. Possuo experiência em Ecologia vegetal, Educação e Melhoramento vegetal. 


\section{ITHANY FELIPE ALCÂNTARA DA SILVA}

Acadêmico em licenciatura no curso de pedagogia, na UNIVERSIDADE DO ESTADO DA BAHIA- UNEB. DCHT Campus XVI. Desenvolve ações de pesquisa e extensão na área de gestão educacional territorialidade e meio ambiente.Membro do Grupo de Pesquisa em Trabalho,Educação,Gestão e Tecnologias - GENTTES. Segundo grau completo no Colégio Estadual João Durval Carneiro.

\section{IZAIAS ROMARIO SOARES DO NASCIMENTO}

Possui curso técnico em Agropecuária (IFCE Crato, 2012-2015), Iniciou Graduação em Agronomia em 2015, no Centro de Ciências Agrárias da Universidade Federal da Paraíba (CCA-UFPB), onde é Bolsista do Programa de Educação Tutorial (PET AgroBio).

\section{JANAINA ALVARENGA ARAGÃO}

Possui graduação em Enfermagem e Obstetrícia pela Fundação de Ensino Superior de Olinda - UNESF (1999), mestrado em Saúde Coletiva pela UNISINOS-Universidade do Vale do Rio dos Sinos (2010) e doutorado em Gerontologia Biomédica pela Pontifícia Universidade Católica do Rio Grande do Sul (PUCRS). Atualmente é Professora Adjunto DE da Universidade Estadual do Piauí, com experiência na área de Saúde Coletiva, e hoje desenvolve pesquisas no semiárido nordestino a cerca do acesso de saúde de adultos de meia idade e idosos remanescentes quilombolas, envelhecimento relacionados a Povos de Comunidades Tradicionais, e Segurança Alimentar e Nutricional.

\section{JAQUELINE DE SOUZA DANTAS}

Técnica em Geologia pelo instituto Federal de Educação, ciência e tecnologia da Paraíba IFPB (2018), integrou o Núcleo de Pesquisa em Geologia e Geofísica Aplicada ao Semiárido (NUGGAP), foi bolsista do CNPq no projeto intitulado "Geofísica rasa aplicada a locação de barragens subterrâneas no semiárido paraibano" (IFPB), exerceu atividade voluntária no projeto intitulado "Avaliação dos impactos ambientais gerados pela mineração no município de Picuí-PB" (IFPB). Atualmente é graduanda em Geografia pela Universidade Federal do Rio Grande do Norte - UFRN, integra o grupo de pesquisa em Estrutura e Evolução de Paisagens do Quaternário, é bolsista no programa PIBITI UFRN (IT) no projeto intitulado "Morfoestratigrafia de depósitos aluviais do Rio Potengi-RN".

\section{JEAN CARLOS DOS SANTOS}

Economista, mestre em economia (UFRN)

\section{JOSÉ FERNANDES DOS SANTOS FILHO}

Graduação Licenciatura em Biologia pela FCE. Pós-Graduação lato Sensu em MBA Perícia, Auditoria e Gestão Ambiental pelo IPOG. Pós-Graduação Mestrado Profissional em Tecnologia Ambiental - Stricto Sensu pelo ITEP. Consultor de projetos ambientais e excursão pelos institutos CETPASS e MONA. Tem experiência na área de Agroecológica e Recursos Florestais. Atualmente atua como Analista Ambiental pelo SEMA na prefeitura Cabo de Santo Agostinho.

\section{JOSÉ PAULO FEITOSA DE OLIVEIRA GONZAGA}

Possui Licenciatura em Ciências Biológicas pela Universidade de Pernambuco; Especialização em Ensino de Biologia pela Universidade Federal Rural de Pernambuco e 
Mestrado Profissional em Tecnologia Ambiental pelo Instituto de Tecnologia de Pernambuco. Possui experiência em ensino de Biologia, Produção agropecuária e Etnobotânica. Atualmente é Professor de Ensino Básico, Técnico e Tecnológico pelo Instituto Federal de Alagoas, Campus Penedo.

\section{JOSEVANIA RODRIGUES JOVELINO}

Graduada e Mestre em Engenharia Química pela Universidade Federal de Campina Grande. Possui experiência na área de Tratamento de águas e tratamento de resíduos sólidos. Foi aluna bolsista no Programa Institucional de Bolsas de Iniciação Científica (PIBIC) na área de membranas cerâmicas e resinas de troca iônica. Apresentou Trabalho de Conclusão de Curso na área de Catálise com Peneiras Moleculares. Estagiou na Universidade Federal de Campina Grande, atuando no Laboratório de Referência em Dessalinização (LABDES) em parceria com a Indústria Cataventos Yvel na área de Perfuração de poços. Apresentou trabalho de dissertação com foco no balanço de massa de metais pesados aplicado ao tratamento de resíduos sólidos.

\section{JULYANNA DAMASCENO PESSOA}

Graduada em Engenharia Química pela Universidade Federal de Campina Grande (2010). Tem experiência na área de Engenharia Química, com ênfase em Operações de Separação e Mistura e Sistemas Particulados, atuando principalmente nos seguintes temas: recobrimento de partículas de extratos fitoterápicos em leito de jorro;dissolução in vitro de extratos fitoterápicos. Mestre em Engenharia Química, com título obtido em 2014, pela Universidade Federal de Campina Grande, com ênfase em Tratamento de Água de Qualidade Inferior, atuando principalmente nos seguintes temas:Avaliação do Desempenho de um Sistema Híbrido com Membrana Cerâmica de Microfiltração E Resina Trocadora Iônica no Tratamento de Águas de Qualidade Inferior. Atualmente Doutoranda em Engenharia Química pela Universidade Federal de Campina Grande na Paraíba, com ênfase em Tratamento de Água de Qualidade Inferior, atuando principalmente no seguinte tema: DESENVOLVIMENTO E MONITORAMENTO DE UM SISTEMA DE MEMBRANAS PARA REÚSO DA ÁGUA E FINS AGRÍCOLAS. Especialista em Engenharia de Segurança do trabalho.

\section{KAMILA FREITAS PORTO}

Tem experiência na área de Química, com ênfase em Química Industrial.

\section{KEPLER BORGES FRANÇA}

Engenheiro Químico pela Universidade Federal da Paraíba, concluiu seu doutorado na University of Kent at Canterbury na Inglaterra. Atualmente, é Professor Titular e pesquisador do Departamento de Engenharia Química da Universidade Federal de Campina Grande. Possui experiência na área da Engenharia Química, com ênfase em processos de membranas voltados para tratamentos de águas para consumo humano. Possui experiência em projetos com membranas de microfiltração, ultrafiltração, nanofiltração e osmose inversa para fins purificação e dessalinização de águas. Coordenou tecnicamente Programas do Governo Federal (Água Doce e Água Boa), para atender comunidades difusas no Nordeste, com água potável a partir de sistemas de dessalinização. Fundou e coordena os Laboratórios de Referência em Dessalinização (LABDES) e de Membranas Cerâmicas (LABCEM), ambos da UFCG, onde desenvolve membranas cerâmicas, além de pesquisas na linha de processos relacionados com os problemas sobre águas e seus tratamentos. 


\section{KILSON PINHEIRO LOPES}

Doutor em Agronomia (PPGA-UFPB), Mestre em Produção Vegetal (PPGA-UFPB), Bacharéu em Engenharia Agronômica (UFPB), Professor do Quadro Permanente de Docentes da Universidade Federal da Campina Grande (UFCG), lotado na Unidade Acadêmica de Ciências Agrárias do Centro de Ciências e Tecnologia Agroalimentar. Tem experiência em Fisiologia e Tecnologia de Sementes, atuando nos seguintes temas: germinação, produção de mudas, ecofisiologia, fisiologia do estresse e armazenamento.

\section{LARISSA BARBOSA DA SILVA}

Graduanda em Biologia pela Universidade Estadual da Paraíba

\section{LAURO BRANDÃO LIMA NETO}

Estudante de Direito da Universidade Estadual do Piauí, atualmente no sétimo bloco. Desenvolve pesquisa cientificas com foco em Direito de família e Direito administrativo. Atualmente estagiário do escritório de advocacia Curica em Picos-PI.

\section{LEONARDO CASILLO}

Possui graduação em Engenharia da Computação pela Universidade Potiguar (2002), mestrado em Sistemas e Computação pela Universidade Federal do Rio Grande do Norte (2005) e doutorado em Engenharia Elétrica e de Computação pela mesma instituição (2013). É professor da Universidade Federal Rural do Semi-Árido desde 2009, lecionando disciplinas de Circuitos Digitais, Microprocessadores e Microcontroladores. Tem experiência na área de Ciência da Computação, com ênfase em hardware, atuando principalmente nos seguintes temas: processadores acadêmicos, processadores RISP e arquiteturas microprogramadas.

\section{LETÍCIA LACERDA FREIRE}

Bacharel em Engenharia Ambiental - Instituto Federal de Educação Ciência e Tecnologia do Ceará - Campus Juazeiro do Norte.

\section{LIDIANE MARINHO TEIXEIRA}

Bacharel em Engenharia Ambiental - Instituto Federal de Educação Ciência e Tecnologia do Ceará - Campus Juazeiro do Norte.

\section{LIGIA MARA GONZAGA}

Engenheira de Minas, pela Universidade Federal de Campina Grande - UFCG e Mestre em Engenharia Metalúrgica e de Materiais pela Universidade Federal do Rio de Janeiro-UFRJ. . Trabalhou como pesquisadora do Programa de Desenvolvimento Tecnológico e Industrial no Centro de Tecnologia Mineral (CETEM) desenvolvendo projetos de pesquisa e desenvolvimento tecnológico nas áreas de Separação Magnética, Flotação e operações unitárias aplicadas no beneficiamento de minerais portadores de terras Raras. Atualmente professora e coordenadora de extensão, pesquisa e inovação do Instituto Federal do Rio Grande do Norte Campos de Parelhas.

\section{LUCELIA DE MOURA ROCHA BARBOSA}


Técnica em aprendizagem profissional comercial em serviços administrativo pelo Senac, estudante de Direito, atualmente no sétimo bloco, desenvolve pesquisas cientificas voltadas para as ciências sociais, enfocando, principalmente, direitos fundamentais, direitos humanos e controle de constitucionalidade.

\section{LÚCIA VIRGINIA CASTOR DO RÊGO}

Doutoranda pelo programa de Pós-graduação em Recursos Naturais pela Universidade Federal de Campina Grande (UFCG), Mestre em Ecologia e Conservação (2017) e graduação em Ciências Biológicas pela Universidade Estadual da Paraíba (2014). Têm experiência na área de Ecologia Vegetal, e Conservação dos Recursos Naturais de origem vegetal, atuando principalmente nos seguintes temas: semiárido, florística e fitossociologia, padrões de distribuição de espécies, biomassa, crioconservação.

\section{LUCIANO SILVA FIGUEIRÊDO}

Atualmente é professor Adjunto, Dedicação Exclusiva da Universidade Estadual do Piauí e professor permanente junto ao Mestrado Profissionalizante em Ensino de Biologia (PROFBIO) e colaborador junto ao Programa de Pós-Graduação em Desenvolvimento e Meio Ambiente (TROPEN) da Universidade Federal do Piauí. Atua principalmente com temas relacionados a Práticas e Conhecimentos de Populações Locais, Conflitos Socioambientais, políticas públicas, Multiculturalismo, Segurança Alimentar e Nutricional, Direitos humanos e religiosidade

\section{LUISA XAVIER DE OLIVEIRA}

Professora Adjunta II da Universidade Federal do Piaui - (UFPI), Doutora em Educação pela Universidade Federal do Rio de Janeiro (UFRJ), Mestre em Educação pela Universidade Estadual do Ceará (UECE, Especialista em Gestão Escolar pela Universidade Estadual de Santa Catarina(UDESC) e Psicomotricidade pela Universidade Estadual do Ceará (UECE). Possui graduação em Licenciatura Plena em Pedagogia pela (UECE). Tem experiência na área de Educação, com ênfase em Formação de Professores. Práticas Pedagógicas, Políticas Públicas e Avaliação da Aprendizagem, atuando principalmente nos seguintes campos de pesquisa: responsabilização escolar (acoountability), desempenho escolar, sistema de ensino, tecnologias da comunicação e informação e ensino/aprendizagem.

\section{MAIARA BEZERRA RAMOS}

Atualmente doutoranda no Programa de Pós Graduação em Etnobiologia e Conservação da Natureza (UFRPE, UEPB, URCA). Mestrado em Ecologia e Conservação, pela Universidade Estadual da Paraíba, e graduada e Licenciatura em Ciências Biológicas pela mesma instituição. Membro do Laboratório de Ecologia Vegetal - LEVe na Universidade Estadual da Paraíba.

\section{MARCELO DA SILVA PEDRO}

Mestrando do Programa de Pós-Graduação em Engenharia Química pela Universidade Federal do Rio Grande do Norte (UFRN). Graduação em Engenharia Química (bacharelado) pela Universidade Federal da Paraíba (2018). Ex-membro fundador da Empresa Júnior de Engenharia Química - PROJEQ da UFPB. Desenvolveu pesquisa na área de Química Analítica no Laboratório de Automação e Instrumentação em Química Analítica e Quimiometria (LAQA-UFPB) e também na área de Simulação e Controle de Processos Químicos no Laboratório de Modelagem Computacional e Controle de 
Processos (LABMC-UFPB). Atualmente, desenvolve pesquisa na área de microdispositivos com foco no desenvolvimento de um sistema de microextração para separação da proteína BSA do soro de leite bovino.

\section{MARCELO VIEIRA DA NÓBREGA}

Possui as seguintes graduações: Letras pela Universidade Estadual da Paraíba (1994), Direito pela Universidade Estadual da Paraíba (2004) e Letras-Libras pela Universidade Federal da Paraíba (2014). Especializações: Linguística Aplicada ao Ensino de Língua Portuguesa (UFPB - 1996) e Direito Processual Penal (Universidade Gama Filho - 2010); Mestrado Interdisciplinar em Ciências da Sociedade pela Universidade Estadual da Paraíba (2003); Doutorando do Programa de Pós-Graduação em Linguística (PROLING) da Universidade Federal da Paraíba; atualmente é professor Efetivo da Universidade Estadual da Paraíba, lotado no Campus I, Departamento de Letras e Artes (DLA) do Centro de Educação - Campina Grande (PB).

\section{MÁRCIA VERÔNICA COSTA MIRANDA}

Possui graduação em Técnico Em Nível Superior Em Processamento de Dado pela Universidade Federal da Paraíba (1985), hoje entitulado Sistemas de Informações, mestrado em Ciência da Computação pela Universidade Federal da Paraíba (1996) e doutorado em Doutorado em Engenharia Elétrica pela Universidade Federal de Campina Grande (2003). Atualmente, é professora associada da Universidade Federal da Paraíba. Tem experiência na área de Engenharia Elétrica, com ênfase em Engenharia da Computação, atuando principalmente nos seguintes temas: Tecnologia da Informação e Comunicação, Educação, Inclusão social, Informática e inclusão digital. Desenvolve e executa diversos projetos na área de extensão universitária, notadamente Extensão rural, com temática na Educação e Inclusão social e digital.

\section{MARCOS ANTONIO PEREIRA DA SILVA}

Bacharel em Engenharia Ambiental - Instituto Federal de Educação Ciência e Tecnologia do Ceará - Campus Juazeiro do Norte.

\section{MARIA ALVENI BARROS VIEIRA}

Doutora em Educação pela Universidade Federal do Rio Grande do Norte. Mestre em Educação pela Universidade Federal do Piauí. Graduada em Pedagogia pela Universidade Estadual do Ceará. Professora Adjunta III da Universidade Federal do Piauí, Campus de Picos - Semiárido piauiense. Desenvolve pesquisas no campo da História da Educação com ênfase nas sociabilidades educativas de crianças e jovens do semiárido nordestino no interstício temporal que cobre os séculos XVIII, XIX, XX.

\section{MARIA DAS DÔRES DE SOUSA}

Doutora em Educação pela Universidade Federal do Rio Grande do Norte. Mestre em Educação pela Universidade Federal do Piauí. Graduada em Ciências Sociais-Sociologia pela Universidade Federal da Paraíba. professora Associada III da Universidade Federal do Piauí \Picos - Semiárido Piauiense. Desenvolve pesquisas na área de educação, diversidades e movimentos sociais. 


\section{MARIA IGNEZ NOVAIS AYALA}

Possui graduação em Letras pela Universidade de São Paulo (1972), mestrado em Letras (Teoria Literária e Literatura Comparada) pela Universidade de São Paulo (1976), doutorado em Letras (Teoria Literária e Literatura Comparada) (1983) e pós-doutorado (1990) pela Universidade de São Paulo, sempre com a orientação do Prof. Dr. João Alexandre Barbosa. É pesquisadora do CNPq desde 1988, com vários projetos concluídos e em andamento, dedicados à literatura e cultura brasileira, especialmente de tradição oral, muitos deles como bolsista nível 1 do CNPq. Também coordenou projetos com apoio de outras instituições (CAPES, IPHAN, BNB). Tem desenvolvido várias atividades de pesquisa voltadas para o patrimônio imaterial brasileiro e de preservação de repertório de mestres tradicionais, entre os quais o projeto de pesquisa? Registros de resistência: a cultura popular tradicional em palavra, som e imagem? (2 ${ }^{\text {a }}$. fase), concluído, e Saberes e fazeres não institucionais, iniciado em 2013, com a primeira fase concluída em 2016, ambos com bolsa do CNPq. Integra o corpo docente do Programa de Pós-Graduação em Linguística da Universidade Federal da Paraíba, em que desenvolve pesquisa, ensino e orientação de doutorandos, como professora colaboradora aposentada. Tem experiência na área de Letras, com ênfase em Teoria Literária, atuando principalmente nos seguintes temas: cultura popular, literatura oral, cultura brasileira, literatura popular e literatura brasileira. Participa de dois Grupos de Pesquisa do CNPq: como líder, junto com Marcos Ayala, no grupo Memória e Cultura, da UFPB.

\section{MARIA VERÔNICA LINS}

Possui graduação em Engenharia Agrônoma pela Universidade Federal da Paraíba-UFPB/ Areia/CCA, Licenciatura em Ciências Agrárias, UFPB/ Bananeiras/CCHSA, Especialista em Educação de Jovens e Adultos, Mestrado em Tecnologia Agroalimentar pela UFPB/Bananeiras/CCHSA, Doutora em Engenharia de Processos pela Universidade Federal de Campina Grande - UFCG. Tem experiência atividades de extensão rural, onde desenvolveu vários trabalhos na cadeia da apicultura e meliponicultura. Coordenou atividades para formação de pastos apícolas, conservação ambiental e de apiários e meliponários, atua como consultora em entrepostos e, na implantação de e acompanhamento em bancos de sementes crioulas no agreste paraibano.

\section{MARIELL LIMA COSTA}

Graduanda em Engenharia Ambiental - Instituto Federal de Educação Ciência e Tecnologia do Ceará - Campus Juazeiro do Norte.

\section{MARÍLIA HORTÊNCIA BATISTA DA SILVA RODRIGUES}

Doutoranda em Agronomia na Universidade Federal da Paraíba - UFPB. Mestre em Horticultura Tropical na Universidade Federal de Campina Grande - UFCG (2018). Graduação em Tecnologia em Agroecologia no Instituto Federal da Paraíba - IFPB (2016). Técnica em Agropecuária pelo IFPB - Campus Sousa (2012). Tem experiência na área de Agroecologia e Agronomia, com ênfase em produção e tecnologia de sementes, atuando principalmente nos seguintes temas: fisiologia e maturação de frutos e sementes, atuando também em pesquisas com produção vegetal, salinidade na água e no solo em horticultura. 


\section{MONICA CARVALHO}

Professora do Centro de Energias Alternativas e Renováveis (CEAR) da Universidade Federal da Paraíba (UFPB). Monica Carvalho cursou Engenharia Elétrica na Universidade Federal da Paraíba (UFCG, Brasil, 2003), mestrado em Engenharia Mecânica-Térmica na Universidade Federal da Paraíba (UFPB, Brasil, 2005), Diploma de Estudos Avançados em Climatização e Eficiência Energética de Edifícios na Universidad de Zaragoza (UniZar, Espanha, 2008), e doutorado em Engenharia Mecânica na Universidad de Zaragoza (UniZar, Espanha, 2011). Seu doutorado recebeu menção de doutorado Europeu, e sua tese recebeu o Premio Extraordinário de Doutorado 2010-2011. Financiação do Conselho de Pesquisa em Ciências Naturais e Engenharia do Canadá (Natural Sciences and Engineering Research Council of Canada (NSERC) Industrial R\&D Fellowship Award) 2011-2013.

\section{NELSON DE ASSIS MEDEIROS JUNIOR}

Bacharel em Engenharia Química pela Universidade Federal da Paraíba. Desenvolveu pesquisas no ramo de produção e análises físico - químicas de fermentos destilados, atuou no ramo de química analítica, no desenvolvimento de uma metodologia de análise de contaminantes emergentes através de técnicas de processos oxidativos, atuou como bolsista no Laboratório De Combustíveis e Materiais (LACOM) trabalhando com a produção de hidrocarbonetos por hidrotratamento a partir de Óleos Vegetais, Estagiou em laboratório de medições ambientais, atuando na área de gestão ambiental, realizando análises de rotina físico-químicas e biológicas de amostras de águas expostas a contaminantes sanitários, foi estagiário industrial no seguimento de revestimento cerâmico, desempenhando o controle e estudo do processo,aluno especial de pós graduação em Engenharia Renováveis UFPB e atua profissionalmente com gestão da qualidade em indústria.

\section{NEYDIANE PEREIRA LOPES}

Professora EBTT do Instituto Federal do Piauí - Campus Valença; Mestranda em administração pela FUNDAÇÃO INSTITUTO CAPIXABA DE PESQUISAS EM CONTABILIDADE, ECONOMIA E FINANÇAS - FUCAPE, linha de pesquisa: Estratégia e Governança Pública e Privada; Possui Graduação em Administração pela Universidade Federal do PiauÍ- UFP I- (2012); Especialização em Gestão pública pela Universidade Estadual do Piauí - UESPI- (2016) ; MBA em Gestão de Pessoas -Universidade Norte do Paraná - UNOPAR; (2016).

\section{NÍVEA MABEL DE MEDEIROS}

Doutoranda em Engenharia de Processos pela UFCG (2018-2021). Mestre em Sistemas Agroindustriais pela UFCG/CCTA (2018). Especialista em Saúde da Família pela FIP (2013). Bacharel em Enfermagem pela FIP (2012). Membro do Grupo de Pesquisa Violência e Saúde -UFCG/CNPq. Editora Executiva da Revista Violência e Saúde do Grupo GVAA. Pesquisadora na área da saúde e afins, com desenvolvimento de pesquisa para. tratamento alternativo por fontes naturais para as DCNT.

\section{OLÍMPIO JOSÉ DOS SANTOS}

Possui graduação em Nutrição pela Universidade Federal do Piauí(2011), graduação em química pela Universidade Estadual do Piauí(2004), especialização em Especialização em Gestão de Recursos Ambientais no Semiárido pelo Instituto Federal do Piauí(2018), especialização em Gestão em Saúde pela Universidade Federal do Piauí(2014) e mestrado 
em Alimentos e Nutrição pela Universidade Federal do Piauí(2017). Atualmente é Professor da Prefeitura Municipal de Aroeira do Itaim-PI.

\section{PAULO SALES DA COSTA BARROS}

Técnico em Mineração e em Geologia pelo IFPB Campus Picuí. Integrante do NUGGAP (Núcleo de Estudo em Geologia e Geofísica Aplicada do Semiárido). Professor do Curso Técnico em Mineração da Escola Estadual Cidadã Integral Técnica Padre Jerônimo Lauwen em Santa Luzia-PB.

\section{RANIELA ALVES TARGINO}

Matemática, mestre em ciências da educação (Universidade Atenas)

\section{RITA DUARTE BRITO DANTAS}

Graduada em Pedagogia em Regime Especial pela Universidade Estadual Vale do Acaraú, Graduada em Letras pela Universidade Regional do Cariri, Graduada em Enfermagem pela Universidade Federal de Campina Grande e pós Graduada em Metodologia do Ensino Fundamental e Médio pela Faculdade Vale do Salgado. Atualmente concursada como Técnica de Enfermagem da Prefeitura Municipal do IcóCE.

\section{ROGÊNIA ARAÚJO CAMPOS}

Mestranda em Ciência e Tecnologia em Sistemas Agroindustriais-CCTA Universidade Federal de Campina Grande. Campus-Pombal. Especialista em Programa Saúde da Família. PSF. Faculdade Integrada do Ceará. FIC. Graduação em Enfermagem Universidade Federal de Campina Grande -UFCG (2017).

\section{RUBENICE DA COSTA CORREIA}

Mestranda em Ecologia e Conservação pela Universidade Estadual da Paraíba

\section{SÉRGIO DE FARIA LOPES}

Professor Titular do Depart. de Biologia (UEPB). Tem experiência na área de Ecologia Vegetal, com ênfase em Ecologia de populações e comunidades. Atualmente Coordenador do Laboratório de Ecologia e Conservação de Florestas Secas (EcoTropics)

\section{SUSANE ETERNA LEITE MEDEIROS}

Bacharel em Física Computacional, mestre em energias renováveis (UFPB) e doutoranda em física (UFPB)

\section{SUZANA GOMES LOPES}

Doutora em Biotecnologia pela Rede Nordeste de Biotecnologia (RENORBIO) pela Universidade Federal do Maranhão, Mestre em Biodiversidade e Conservação também pela Universidade Federal do Maranhão e graduada em Licenciatura Plena e Bacharelado no Curso de Ciências Biológicas da Universidade Regional do Cariri. Atualmente é Professora Efetiva do Curso de Licenciatura em Educação do Campo/Ciências da Natureza da Universidade Federal do Piauí (UFPI), campus Senador Helvídio Nunes de Barros, onde realiza pesquisas voltadas para Educação do Campo, com ênfase no Ensino de Ciências. 


\section{TAMARIS GIMENEZ PINHEIRO}

Possui graduação em Ciências Biológicas pela Universidade Federal de Mato Grosso, Mestrado em Ecologia e Conservação da Biodiversidade, pelo Instituto de Biociências também da Universidade Federal de Mato Grosso e Doutorado em Ciências Biológicas Área Zoologia, pela Universidade Estadual Paulista "Júlio de Mesquita Filho", UNESP campus de Rio Claro. Atua como Professora Efetiva do curso de Licenciatura em Educação do Campo/Ciências da Natureza, da Universidade Federal do Piauí, campus Senador Helvídio Nunes de Barros desde 2014, onde orienta Trabalhos de Conclusão de Curso na área de Educação do Campo e em Ensino de Ciências.

\section{THATIANNY JASMINE CASTRO MARTINS DE CARVALHO}

Professora assistente da Universidade Federal do Piauí, no campus Senador Helvídio Nunes de Barros. Possui graduação em Licenciatura Plena em Pedagogia pela Universidade Federal do Piauí e mestrado em Educação pela Universidade Federal do Ceará. Doutoranda no Programa de Pós-Graduação em Educação Brasileira, na linha de pesquisa História e Educação Comparada, da Universidade Federal do Ceará. Membro do Núcleo de Estudos e Pesquisas em Teorias e Práticas Pedagógicas (NUTEPP/UFPI). Membro do Núcleo de Estudos e Pesquisas em Educação e Emancipação Humana (NESPEM/UFPI). Membro da Sociedade Brasileira de História da Educação (SBHE). Tem experiência na área de Educação, com ênfase em Formação de Professores, Infância, História da Educação e Currículo.

\section{VIVIANE BRITO VIANA}

Possui graduação em Administração e mestrado em Desenvolvimento Regional Sustentável pela Universidade Federal do Ceará (2015). Atualmente é professora do quadro efetivo do Instituto Federal do Ceará, lecionando disciplinas de Gestão Empresarial, Empreendedorismo com ênfase na Sustentabilidade. Tem experiência na área de Administração no âmbito público e privado, atuando principalmente nos seguintes temas: mercado, água, mineração e sustentabilidade.

\section{WALLYSSON KLEBSON DE MEDEIROS SILVA}

Economista, mestre em energias renováveis (UFPB) e doutorando em administração (UFPB)

\section{WANDERLEYA KELLIANE LEMOS PIMENTEL}

Graduanda em Medicina Veterinária pela Universidade Federal de Campina Grande

\section{WILLIAMS ALVES XAVIER}

Graduando em Agronomia pela Universidade Federal da Paraíba - Campus II, atualmente é voluntário em projetos de extensão universitária do Departamento de Ciências Fundamentais e Sociais, na área de inclusão rural através da informática. Também é estagiário do Departamento de Fitotecnia do centro e foi monitor bolsista das disciplinas de Informática e Química Orgânica. É Técnico em Administração formado pela Escola Técnica Miguel Arraes de Alencar - PE, e durante o ensino médio realizou intercâmbio na Harbour View High School - Canadá. 


\section{ZILDENICE MATIAS GUEDES MAIA}

Doutora em Ciências Sociais pela Universidade Federal do Rio Grande do Norte (20142018); Mestre em Ambiente, Tecnologia e Sociedade pela Universidade Federal Rural do Semi-Árido (2013);Especialista em Perícia, Auditoria e Gestão Ambiental pelo Instituto de Pós-graduação (2010)Bacharela em Gestão Ambiental pela Universidade do Estado do Rio Grande do Norte (2010). É pesquisadora colaboradora do Laboratório de Estudos Rurais da Universidade Federal do Rio Grande do Norte (LabRural). 


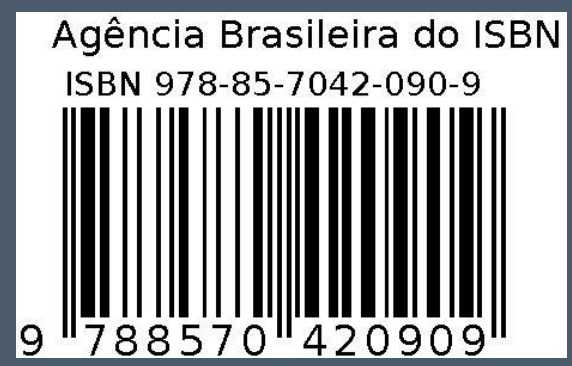

